LESSER SLAVE RIVER INSTREAM FLOW NEEDS SCOPING STUDY

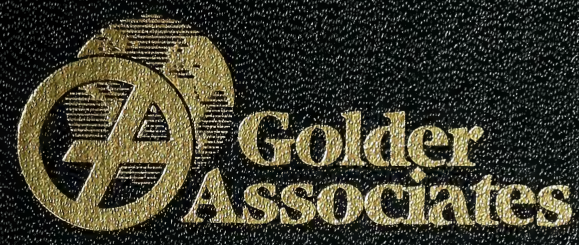


Golder Associates Ltd.

1000, 940 - 6th Avenue S.W.

Calgary, Alberta, Canada T2P $3 \mathrm{TI}$

Telephone 403-299-5600

Fax 403-299-5606
FINAL REPORT

\section{LESSER SLAVE RIVER INSTREAM FLOW NEEDS \\ SCOPING STUDY}

Submitted to:

Alberta Environment
Northern Region
Peace River, Alberta

March 2004

ISBN: 0-7785-4594-6 (Printed)

ISBN: 0-7785-4595-4 (On-line)

Pub No. I/010
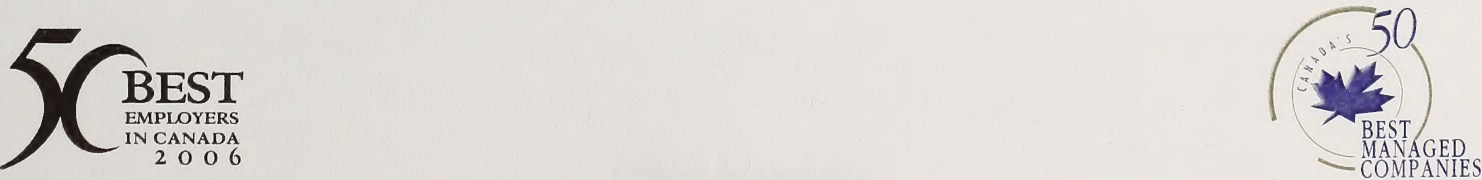
Digitized by the Internet Archive in 2016

https://archive.org/details/lesserslaveriver00gold 


\section{EXECUTIVE SUMMARY}

As a component of a water management plan for the Lesser Slave Lake and Lesser Slave River basins, an Instream Flow Needs Technical Committee (IFNTC) was formed to address the instream needs of the Lesser Slave River. The objective of the IFNTC is to:

Develop a defensible, science-based IFN recommendation that provides full, long-term protection to the aquatic ecosystem for the Lesser Slave River.

Golder Associates Ltd. (Golder) was retained by Alberta Environment (AENV) to develop a scope of work for conducting an IFN study on the Lesser Slave River. The objectives of this report are to:

- review and summarize existing data on hydrology, channel morphology, ice processes, water quality, benthic invertebrates, fish habitat and riparian ecosystems of the Lesser Slave River;

- identify potential data gaps necessary for completing an IFN evaluation;

- provide a work plan for completing any additional field work and the development of an IFN determination for the Lesser Slave River; and,

- propose a flow evaluation framework for assessing year-round instream flow needs.

The general framework being proposed for the Lesser Slave River IFN study is based on the principles of the Instream Flow Incremental Methodology (IFIM). The IFIM is a decision support system developed by the U.S. Fish and Wildlife Service designed to help solve water resource allocation problems. Although many of the tools developed for use with IFIM are only applicable to open-water conditions, there are typical steps that should be followed to support rational water management decisions. Several key principles that are particularly relevant to a successful IFN study on the Lesser Slave River include:

- agreement on the approach by all stakeholders at the planning stage;

- assemble an inter-disciplinary team to conduct the work;

- select an appropriate method to address specific problems; and, 
- identify concise study objectives that are feasible in terms of data collection limitations, modelling approaches, and realistic timeline constraints.

Five main ecosystem components have been identified by IFN practitioners that should be considered in an IFN study: hydrology, channel morphology, water quality, biology, and connectivity. The data review for the Lesser Slave River focused on seven different aspects of the Lesser Slaver River system including hydrology, channel morphology, ice processes, water quality, benthic invertebrates, riparian ecosystems and fish and fish habitat (including connectivity issues). The data review for the Lesser Slave River covers all aspects of the riverine ecosystem necessary for an ecosystem-based IFN study.

In general, data on the Lesser Slave River are sufficient to develop an IFN within two to three years after study implementation that incorporates multiple ecosystem components into the final IFN recommendation. Channel morphology and riparian ecosystems, which rely on higher flows, do not appear to be a major concern at this point based on current water management but can be incorporated into the IFN using fairly simple calculations from data collected at the habitat modelling sites. The existing monitoring data for water quality and benthic invertebrates are sufficient to conduct exploratory correlation analyses to determine if there are any flow sensitive parameters. This information may be suitable to develop an IFN recommendation or a decision would have to be made by the IFNTC to investigate more detailed approaches.

The availability of data to complete a fish habitat modelling study to incorporate into the IFN recommendation is poor. General fisheries data are lacking to define the distribution of key fish species, once these key species have been determined. A series of fisheries studies have been recommended to fill in some of the major data gaps including identifying spawning and overwintering locations on the Lesser Slaver River. In addition, habitat mapping and thermal infra-red information are needed prior to selecting study sites for habitat modelling.

A habitat modelling approach is recommended for the fish habitat assessment using the River2D two-dimensional hydrodynamic model. The timing of data collection for input into the River2D model should not commence until the 2005 season to allow for all of the necessary background information to be collected to facilitate optimal study site selection. A series of expert workshops will likely be required during the process to fill in any additional data gaps remaining after efforts 
at data collection have been pursued. The workshops would be cost effective; however, they add uncertainty to the process by relying on information that may not be specific to the Lesser Slave River. The uncertainty from the lack of site-specific data may be acceptable if all interested parties agree to the process, and the potential limitations of the process, prior to beginning the process. Evaluating a fish habitat IFN for the winter period remains uncertain as tools are still under development that would allow for a winter habitat evaluations. Alternate approaches, such as using a fall spawning evaluation, may be suitable for the Lesser Slave River; however, the evaluation protocols would have to be developed by the IFNTC since a standard winter approach is not available for Alberta.

Integration of the IFN results from the different ecosystem components should follow the approach developed for the South Saskatchewan River Basin by Alberta Environment and Alberta Sustainable Resource Development. Final determination of the IFN would be left up to the IFNTC. Even with an expedited schedule, a final IFN recommendation would not likely be available prior to 2006 if any habitat modelling is conducted, and perhaps later if winter habitat modelling is included in the program. A summary of the approximate budget and proposed work plan schedule to complete the major tasks in the study design are provided below.

\begin{tabular}{|c|c|c|c|}
\hline Task & Timing & Duration & $\begin{array}{c}\text { Approximate } \\
\text { Cost }\end{array}$ \\
\hline \multicolumn{4}{|l|}{ Channel Morphology } \\
\hline Determine IFN from Shields Equation & $\begin{array}{l}\text { After fish habitat } \\
\text { surveys }\end{array}$ & 1 day & $\$ 1,000$ \\
\hline \multicolumn{4}{|l|}{ Riparian } \\
\hline Review historic air photos & May 2004 & 1 week & $\$ 5,000$ \\
\hline Evaluate Riparian Condition & July 2005 & 2 weeks & $\$ 10,000$ \\
\hline \multicolumn{4}{|l|}{ Hydrology } \\
\hline Review synthesized flow data & May 2004 & 1 week & $\$ 5,000$ \\
\hline Extend time series using regression & June 2004 & 1 week & $\$ 5,000$ \\
\hline Set up new model for naturalization & June-July 2004 & 4-6 weeks & $\$ 30,000$ \\
\hline \multicolumn{4}{|l|}{ Water Quality } \\
\hline $\begin{array}{l}\text { Conduct exploratory analysis (including data } \\
\text { entry of raw data) }\end{array}$ & May 2004 & 2 weeks & $\$ 10,000$ \\
\hline $\begin{array}{l}\text { Set up water quality model (if needed } \\
\text { assuming no additional data) }\end{array}$ & June-July 2004 & 4 weeks & $\$ 20,000$ \\
\hline Collect additional data & TBD & TBD & TBD \\
\hline
\end{tabular}




\begin{tabular}{|c|c|c|c|}
\hline Task & Timing & Duration & $\begin{array}{l}\text { Approximate } \\
\text { Cost }\end{array}$ \\
\hline \multicolumn{4}{|l|}{ Benthic Invertebrates } \\
\hline $\begin{array}{l}\text { Conduct exploratory analysis (including data } \\
\text { entry of raw data) }\end{array}$ & May 2004 & 2 weeks & $\$ 10,000$ \\
\hline Develop HSC using existing data (if possible) & $\begin{array}{l}\text { After exploratory } \\
\text { analysis }\end{array}$ & 1 week & $\$ 5000$ \\
\hline Collect additional data & TBD & TBD & TBD \\
\hline \multicolumn{4}{|l|}{ Habitat Mapping } \\
\hline $\begin{array}{l}\text { High resolution aerial photography } \\
\text { (orthorectified) }\end{array}$ & April 2004 & & $\$ 20,000$ \\
\hline Habitat delineation & May 2004 & 1 week & $\$ 5,000$ \\
\hline Thermal infra-red photography & November 2004 & & $\$ 3,000$ \\
\hline \multicolumn{4}{|l|}{ Fish Species Distribution } \\
\hline Spring Inventory & April-May & 6 weeks & $\$ 95,000$ \\
\hline Summer Inventory & July-August & 2 weeks & $\$ 45,000$ \\
\hline Fall Inventory & October-November & 2 weeks & $\$ 35,000$ \\
\hline Winter Inventory & December/February & 3 weeks & $\$ 35,000$ \\
\hline Expert Workshop & $\begin{array}{l}\text { Anytime after data } \\
\text { collection }\end{array}$ & $1-2$ days & $\begin{array}{l}\text { Participant } \\
\text { Dependant }\end{array}$ \\
\hline \multicolumn{4}{|l|}{ Develop HSC Curves } \\
\hline $\begin{array}{l}\text { Collect data (Open-water, cost reduced } \\
\text { combined with inventory for savings }\end{array}$ & $\begin{array}{l}\text { All seasons (in } \\
\text { combination with } \\
\text { inventory) }\end{array}$ & 2 weeks & $\$ 20,000$ \\
\hline Collect data (Winter) & December/February & 3 weeks & $\begin{array}{l}\text { Incl. winter } \\
\text { inventory }\end{array}$ \\
\hline Data analysis & $\begin{array}{l}\text { Immediately after data } \\
\text { collection }\end{array}$ & 1 week & $\$ 5,000$ \\
\hline Expert Workshop & $\begin{array}{l}\text { Anytime after data } \\
\text { collection }\end{array}$ & $1-2$ days & $\begin{array}{l}\text { Participant } \\
\text { dependant }\end{array}$ \\
\hline Telemetry program & Assess after first winter & & $\begin{array}{r}>\$ 100,000 \text { per } \\
\text { year }\end{array}$ \\
\hline \multicolumn{4}{|l|}{ Hydraulic Modelling } \\
\hline $\begin{array}{l}\text { Study site selection, open water survey, } \\
\text { stage-discharge, calibration }\end{array}$ & $\begin{array}{l}\text { Descending limb of } \\
\text { hydrograph (2005) }\end{array}$ & $\begin{array}{l}3 \text { weeks per } \\
\text { site }\end{array}$ & $\$ 50,000 /$ site \\
\hline Under ice survey, stage-discharge, calibration & $\begin{array}{l}\text { Winter following open- } \\
\text { water survey }\end{array}$ & $\begin{array}{l}3 \text { weeks per } \\
\text { site }\end{array}$ & $\$ 50,000 /$ site \\
\hline \multicolumn{4}{|l|}{ IFN Development } \\
\hline $\begin{array}{l}\text { Integrate IFN results using established } \\
\text { protocols }\end{array}$ & After all data collection & 3 weeks & $\$ 15,000$ \\
\hline
\end{tabular}




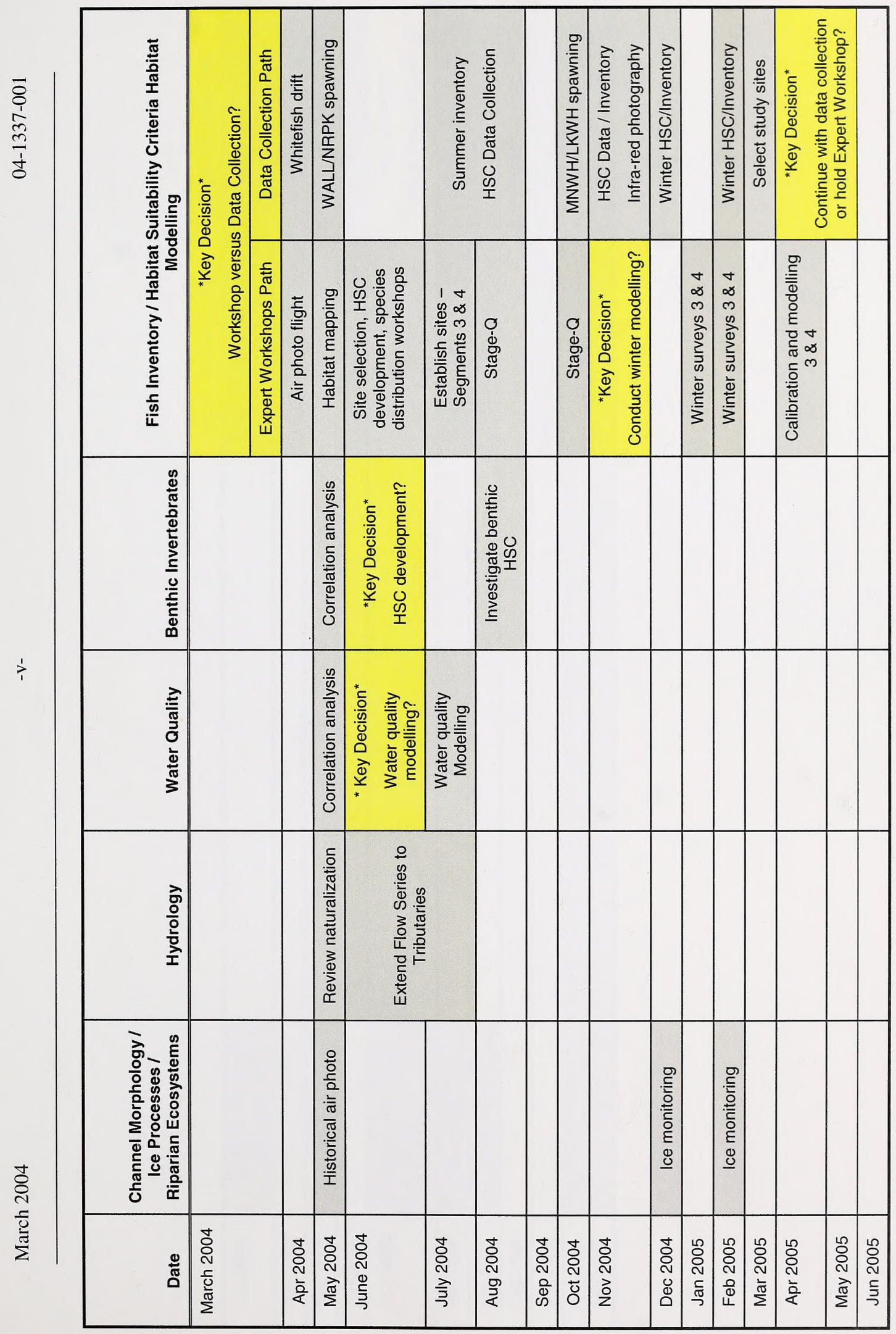





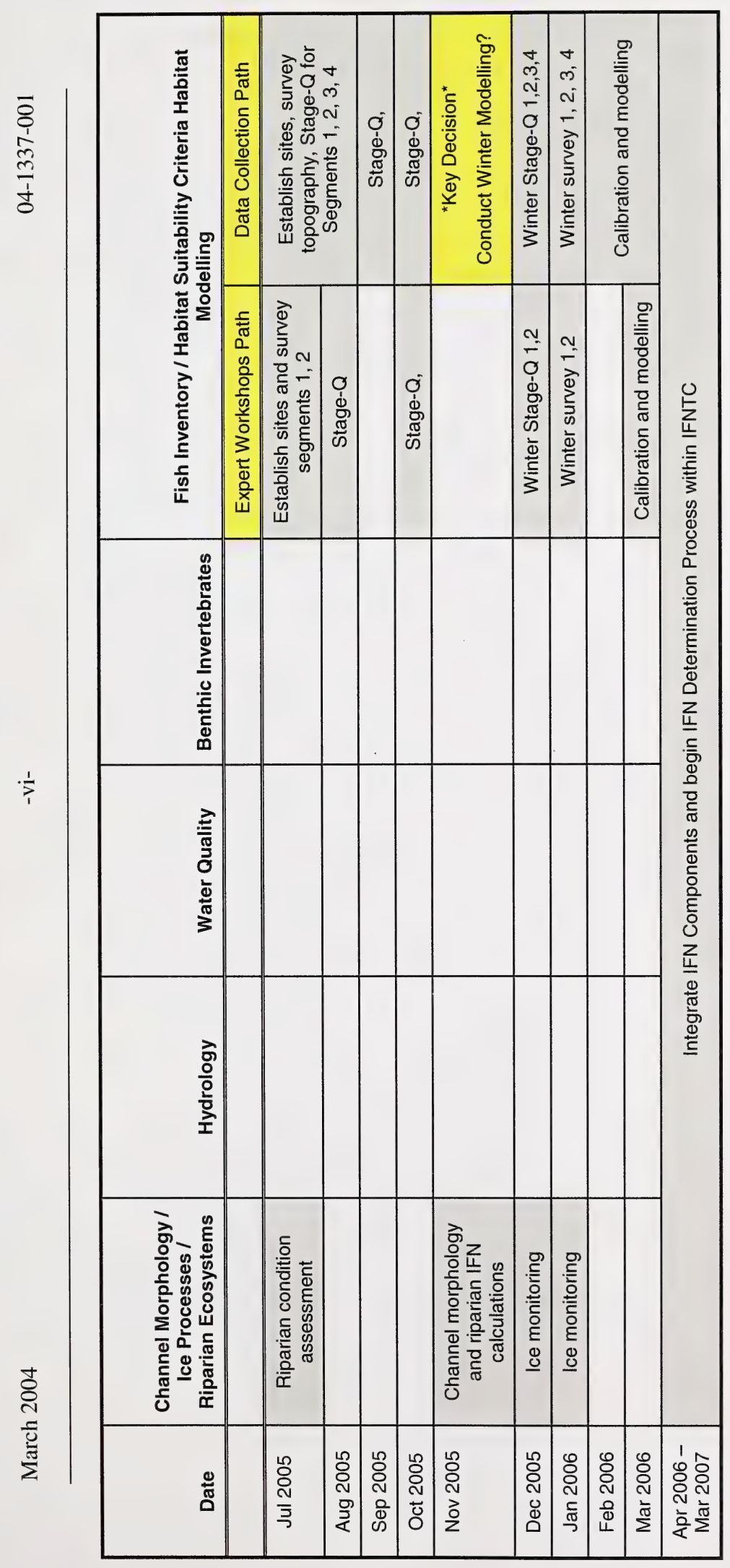

$\frac{y}{0}$
$\frac{0}{0}$
$\frac{0}{8}$
$\frac{0}{2}$
$\frac{1}{0}$
$\frac{0}{0}$
0 



\section{ACKNOWLEDGEMENTS}

This report was compiled by an interdisciplinary study team at Golder Associates under the direction of Anil Beersing (Hydrology), Terry Winhold (Channel Morphology), Zsolt Kovats (Water Quality and Benthos), Sandra Marken (Riparian), and Jim O'Neil (Fish Habitat). Significant contribution to the data compilation and reporting were also made by Austin Adams, Darrell Jobson, Melanie Neufeld and Prem Premasiri.

The study team would like to thank the efforts of Tim Toth from Alberta Environment for providing project direction and his tireless effort during the project to ensure data were made available in a timely manner. Members of the Lesser Slave River IFNTC were also extremely helpful in providing much of the data used in the background summary sections and for their comments on the draft report. 


\section{TABLE OF CONTENTS}

\section{SECTION}

PAGE

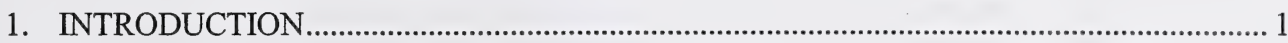

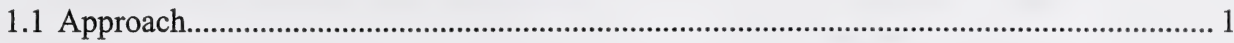

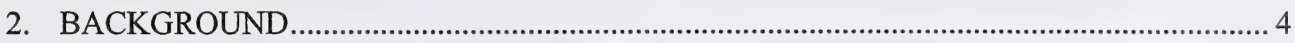

2.1 Instream Flows for the Protection of Riverine Ecosystems ............................................. 4

2.2 Winter IFN Approaches in Other Jurisdictions ............................................................. 4

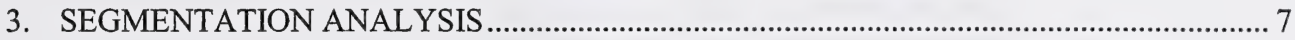

3.1 Segmentation Methods ............................................................................................. 7

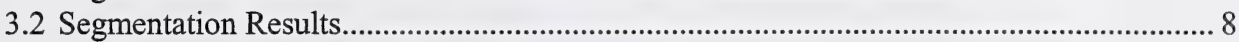

4. LESSER SLAVE RIVER ECOSYSTEM COMPONENT BACKGROUND

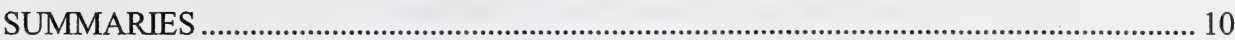

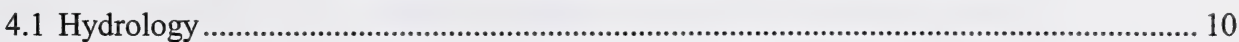

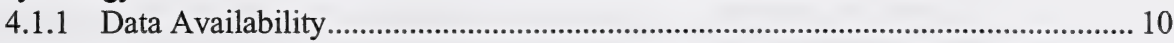

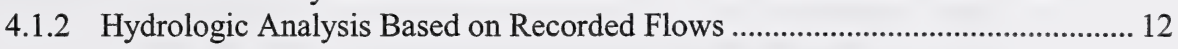

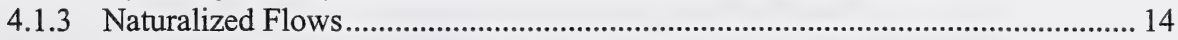

4.1.4 Hydrologic Analysis Based on Naturalized Flows ......................................... 14

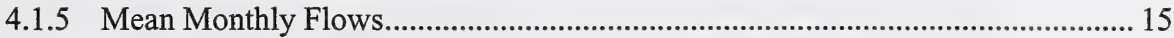

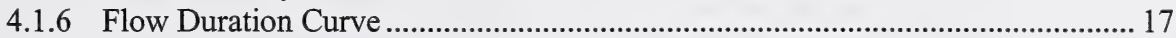

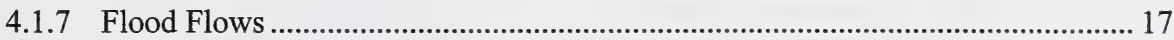

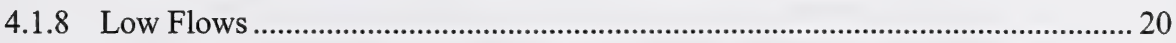

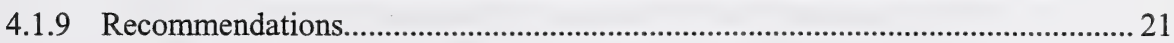

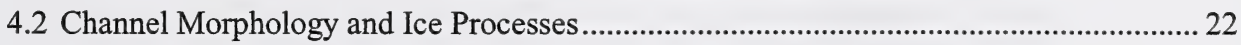

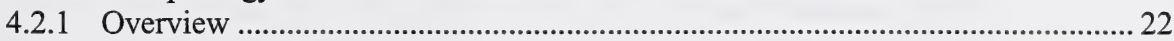

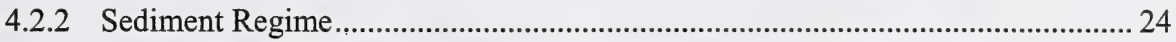

4.2.3 Impacts from Weir and Channel Cutoff Construction........................................ 26

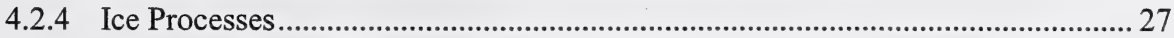

4.2.5 Effects of Changed Flow Regime .................................................................. 29

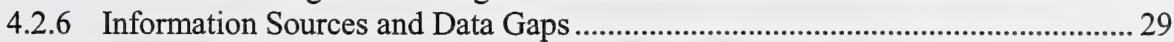

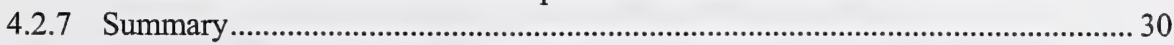

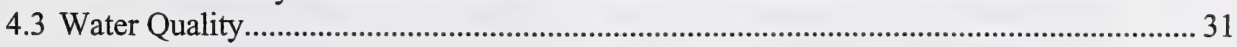

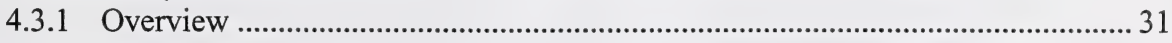

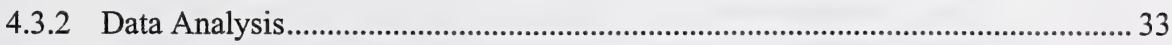

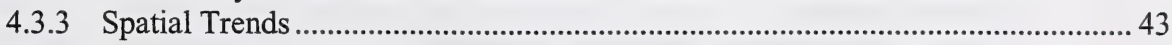

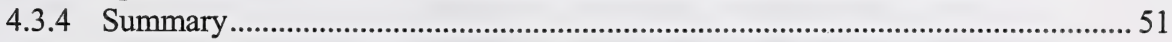

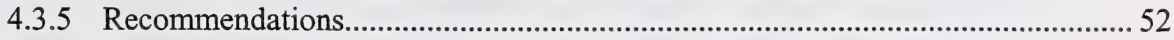

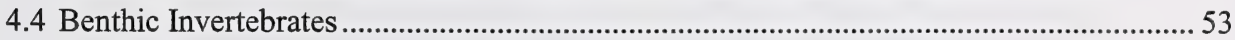

4.4.1 Previous Surveys in the Lesser Slave River ...................................................... 53

4.4.2 Importance of Flow and Winter Conditions .................................................. 55

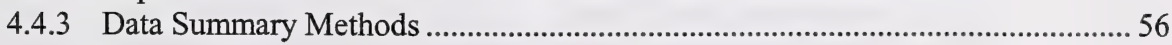

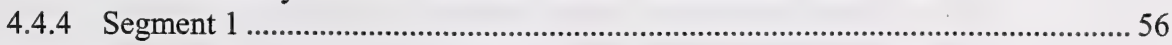

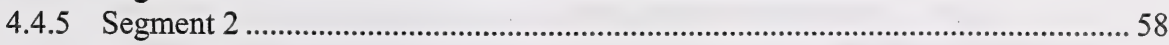

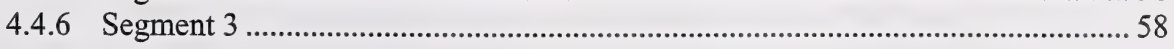




\section{TABLE OF CONTENTS}

\section{SECTION}

PAGE

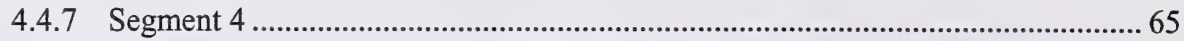

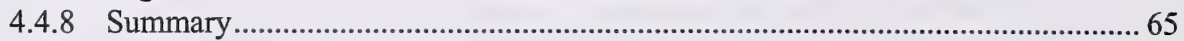

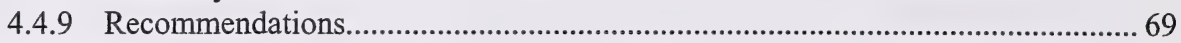

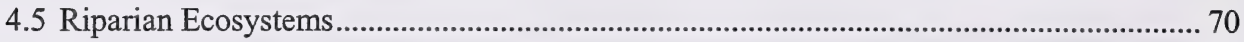

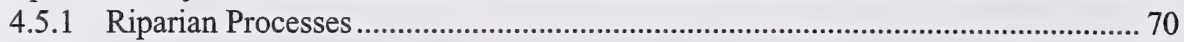

4.5.2 Biogeographic Information.............................................................................. 71

4.5.3 Hydrological Influence on Riparian Ecosystems.............................................. 72

4.5.4 Riparian Geomorphology ............................................................................ 72

4.5.5 Literature Review ........................................................................................ 73

4.5.6 Alberta Vegetation Inventory ....................................................................... 74

4.5.7 AVI of the Lesser Slave River ..................................................................... 74

4.5.8 Aerial Photographs .................................................................................. 75

4.5.9 Aerial Photograph Reach Specific Information.................................................... 75

4.5.10 Further Research Recommendations ................................................................. 77

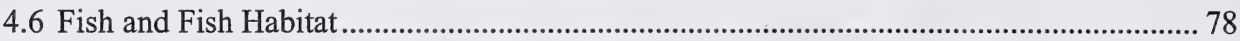

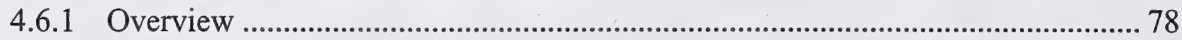

4.6.2 Habitat Suitability Information........................................................................ 84

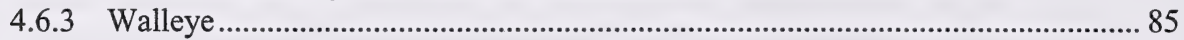

4.6.4 Northern Pike........................................................................................ 88

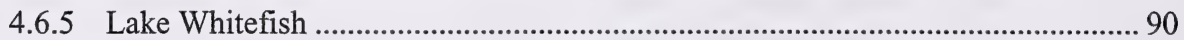

4.6.6 Mountain Whitefish ....................................................................................... 92

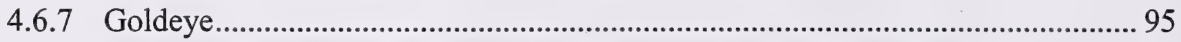

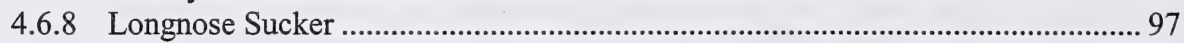

4.6.9 White Sucker …………………………................................................... 99

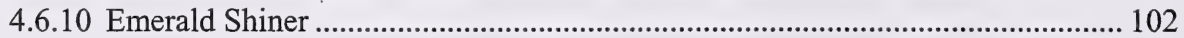

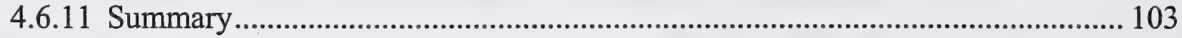

5. INSTREAM FLOW NEEDS ASSESSMENT FRAMEWORK..........................................112

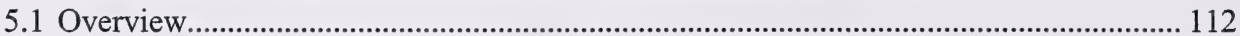

5.1.1 Winter IFN Approaches.................................................................................. 113

5.2 Lesser Slave River IFN Framework ……………………………………………... 114

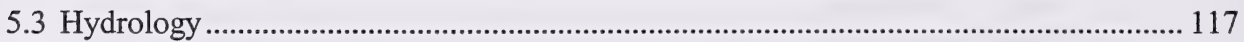

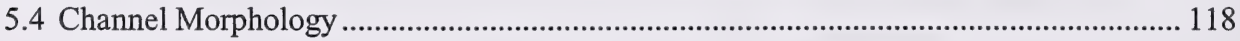

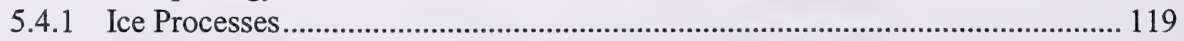

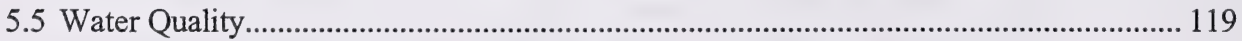

5.6 Biological Processes - Riparian Ecosystems ……………………………………...... 120

5.7 Biological Processes - Benthic Invertebrates.............................................................. 121

5.8 Biological Processes - Fish Habitat ............................................................................... 122

5.8.1 Key Fish Distribution and Timing ................................................................... 123

5.8.2 Habitat Suitability Criteria................................................................................ 124

5.8.3 Selection of Study Sites........................................................................... 125

5.8.4 Data Collection for Model Input....................................................................... 126

5.8.5 Evaluation Approaches ................................................................................... 127

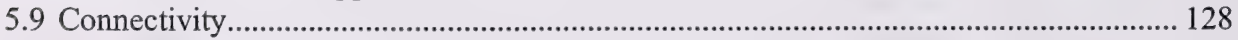

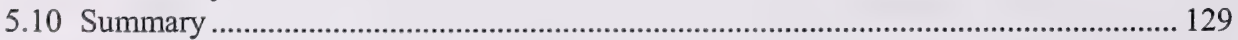




\section{TABLE OF CONTENTS}

\section{SECTION}

PAGE

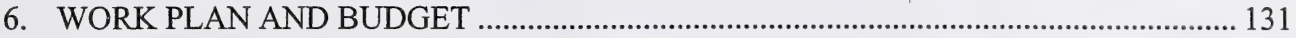

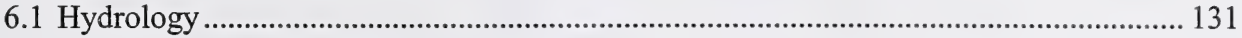

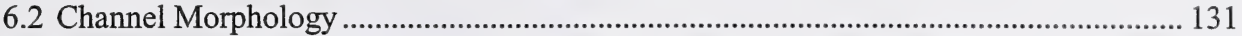

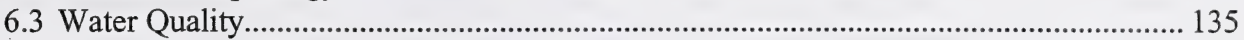

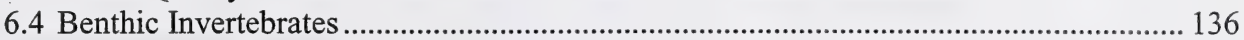

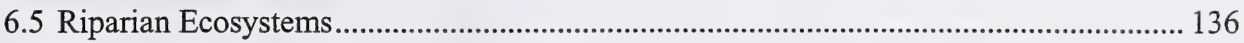

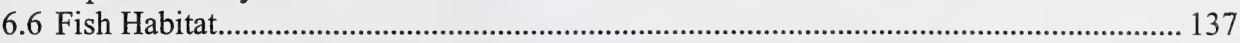

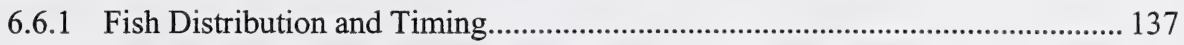

6.6.2 Habitat Suitability Criteria - Open Water ....................................................... 139

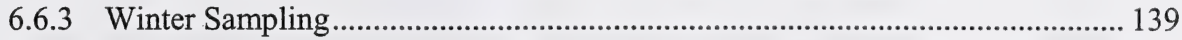

6.6.4 Habitat Mapping and Thermal Infra-red Photography ..................................... 140

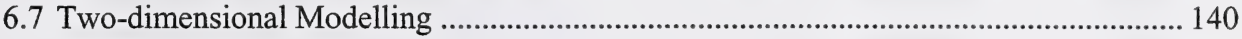

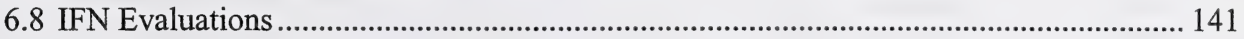

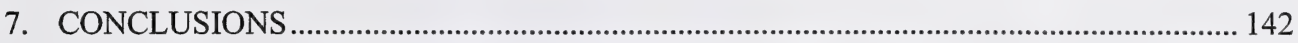

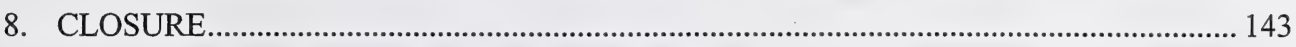

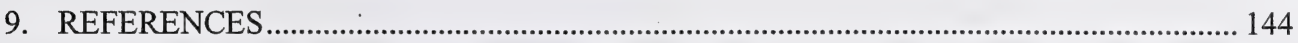




\section{LIST OF TABLES}

Table 1 Gauging and Flow Characteristics in Lesser Slave Lake Watershed.................... 11

Table 2 Derived Mean Monthly Flows Based on Naturalized Flows (1970-1999)

Assuming No Regulation of Lesser Slave Lake .................................................. 16

Table 3 Derived Mean Monthly Flows Based on Predicted Regulated Flows

(1970-1999) Assuming Regulation of Lesser Slave Lake

Table 4 Flood Flows at the Outlet of Lesser Slave Lake Based on Naturalized and

Regulated Flows (1970-1999)........................................................................... 19

Table 5 Low Flows at the Outlet of Lesser Slave Lake Based on Naturalized and Regulated Flows (1971-1999)......................................................................... 20

Table $6 \quad$ Geomorphic Characteristics of the Lesser Slave River ${ }^{1}$........................................ 23

Table $7 \quad$ Water Quality Guidelines for the Protection of Aquatic Life ................................ 34

Table 8 Summary Statistics for Water Quality Parameters within Segment 1 ................. 35

Table 9 Summary Statistics for Water Quality Parameters within Segment 2 ................. 37

Table $10 \quad$ Summary Statistics for Water Quality Parameters within Segment 3 ................. 39

Table 11 Summary Statistics for Water Quality Parameters within Segment 4 ................ 41

Table 12 Summary Statistics for Water Quality Parameters within Segment 5 ................ 42

Table 13 Fish Species Documented to be Present in the Mainstem Lesser Slave

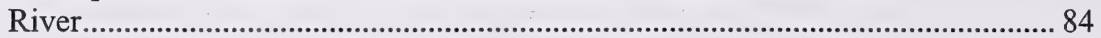

Table 14 Summary of Timing and Distribution for Fish Species Segment 1 ................. 106

Table 15 Summary of Timing and Distribution for Fish Species - Segment 2 ................ 107

Table 16 Summary of Timing and Distribution for Fish Species - Segment 3 ................ 108

Table 17 Summary of Timing and Distribution for Fish Species - Segment 4 ................ 109

Table 18 Summary of Timing and Distribution for Fish Species - Segment 5 ............... 110

Table 19 Proposed Work Plan for the Lesser Slave River IFN Study, 2004-2006 ........... 132

Table 20 Proposed Budget Summary for the Lesser Slave River IFN Work Plan, 2004-2006 


\section{LIST OF FIGURES}

Figure 1

Figure 2

Figure 3

Figure 4

Figure 5

Figure 6

Figure 7

Figure 8

Figure 9

Figure 10

Figure 11

Figure 12

Figure 13

Figure 14

Figure 15

Figure 16

Figure 17

Figure 18

Figure 19

Figure 20

Figure 21

Figure 22

Figure 23

Figure 24

Figure 25

Figure 26
Study Area Base Map 2

Segmentation Analysis 9

Period of Recorded Data at Gauges in Lesser Slave Lake Watershed. 11

Naturalized Daily Flows Downstream of Lesser Slave Lake ... 13

Daily Flow Exceedence Curves on Lesser Slave River, 1970-1999. 18

Comparison of Naturalized versus Regulated Flow Exceedence Curves at Lesser Save Lake Outlet, 1970 - 1999 18

Comparison of Naturalized versus Regulated Flow Exceedence Curves

Downstream of the Saulteaux River, 1970 - 1999

Water Quality Sampling Sites in the Lesser Slave River...................................... 32

Dissolved Oxygen in Each Segment by Season....................................................... 44

Total Dissolved Solids in Each Segment by Season ............................................. 45

Dissolved Organic Carbon in Each Segment by Season....................................... 46

Total Suspended Solids in Each Segment by Season............................................ 47

Total Phosphorus in Each Segment by Season .......................................................48 48

Total Kjeldahl Nitrogen in Each Segment by Season ........................................... 49

Total Iron in Each Segment by Season .............................................................. 50

Historical Benthic Invertebrate Sampling Sites in the Lesser Slave River ........... 54

Total Invertebrate Abundance, Richness and Community Composition at

Erosional Site 87 in Segment 1 in the Lesser Slave River.

Total Invertebrate Abundance, Richness and Community Composition at Erosional Site 42 in Segment 2 in the Lesser Slave River.

Total Invertebrate Abundance, Richness and Community Composition at Erosional Sites 26 and 37 in Segment 3 in the Lesser Slave River during the Fall

Total Invertebrate Abundance, Richness and Community Composition in Spring and Fall, at Erosional Sites 26 and 37 in Segment 3 in the Lesser Slave River...

Total Invertebrate Abundance, Richness and Community Composition at Erosional Sites Upstream and Downstream of Slave Lake Pulp in 1998.

Total Invertebrate Abundance and Richness at Six Depositional Sites in Segment 3 in the Lesser Slave River during the Fall.

Community Composition at Six Depositional Sites in Segment 3 in the

Lesser Slave River 66

Total Invertebrate Abundance, Richness and Community Composition at Sites in Segment 4 in the Lesser Slave River.

Fish Sampling Study Locations .

Lesser Slave River Conceptual IFN Framework Flow Diagram . 115

\section{LIST OF APPENDICES}

Appendix I Supplementary Hydrologic and Morphologic Data 



\section{INTRODUCTION}

The Lesser Slave River is located in northwestern Alberta and flows for approximately $72 \mathrm{~km}$ from Lesser Slave Lake to the Athabasca River (Figure 1). The flows in the Lesser Slave River have been altered as a result of the construction of a fixed-crest weir in 1982 at the outlet of the lake and a series of channel cutoffs extending approximately $16 \mathrm{~km}$ downstream from the weir. Recent dry years in which flows below the weir nearly ceased have brought forward concerns about flow management on the Lesser Slave River (AENV 2000). As a component of a water management plan for the Lesser Slave Lake and Lesser Slave River basins, an Instream Flow Needs Technical Committee (IFNTC) was formed to address the instream needs of the Lesser Slave River. The objective of the IFNTC is to:

\section{Develop a defensible, science-based IFN recommendation that provides full, long-term protection to the aquatic ecosystem for the Lesser Slave River.}

The Lesser Slave River supplies water to municipal, industrial and irrigation users as well as supporting a diverse fish community. It also receives treated municipal effluent from the Town of Slave Lake as well as pulp mill effluent from Slave Lake Pulp Corporation. A key area of concern on the Lesser Slave River is winter flow conditions when the river is covered in ice. Under-ice IFN work has not been conducted in Alberta and no other studies from other jurisdictions are available in the published literature to provide a tested and validated approach for conducting an under-ice IFN study. Conducting biological studies under ice is also a challenge, and very limited information is available about under-ice biology for most fish species. A scoping study is a necessary first step in the IFN process to identify areas of concern, data gaps, define the study bounds and propose an assessment framework and work plan that is acceptable to all stakeholders.

\subsection{Approach}

Golder Associates Ltd. (Golder) was retained by Alberta Environment (AENV) to develop a scope of work for conducting an IFN study on the Lesser Slave River. The objectives of this report are to: 



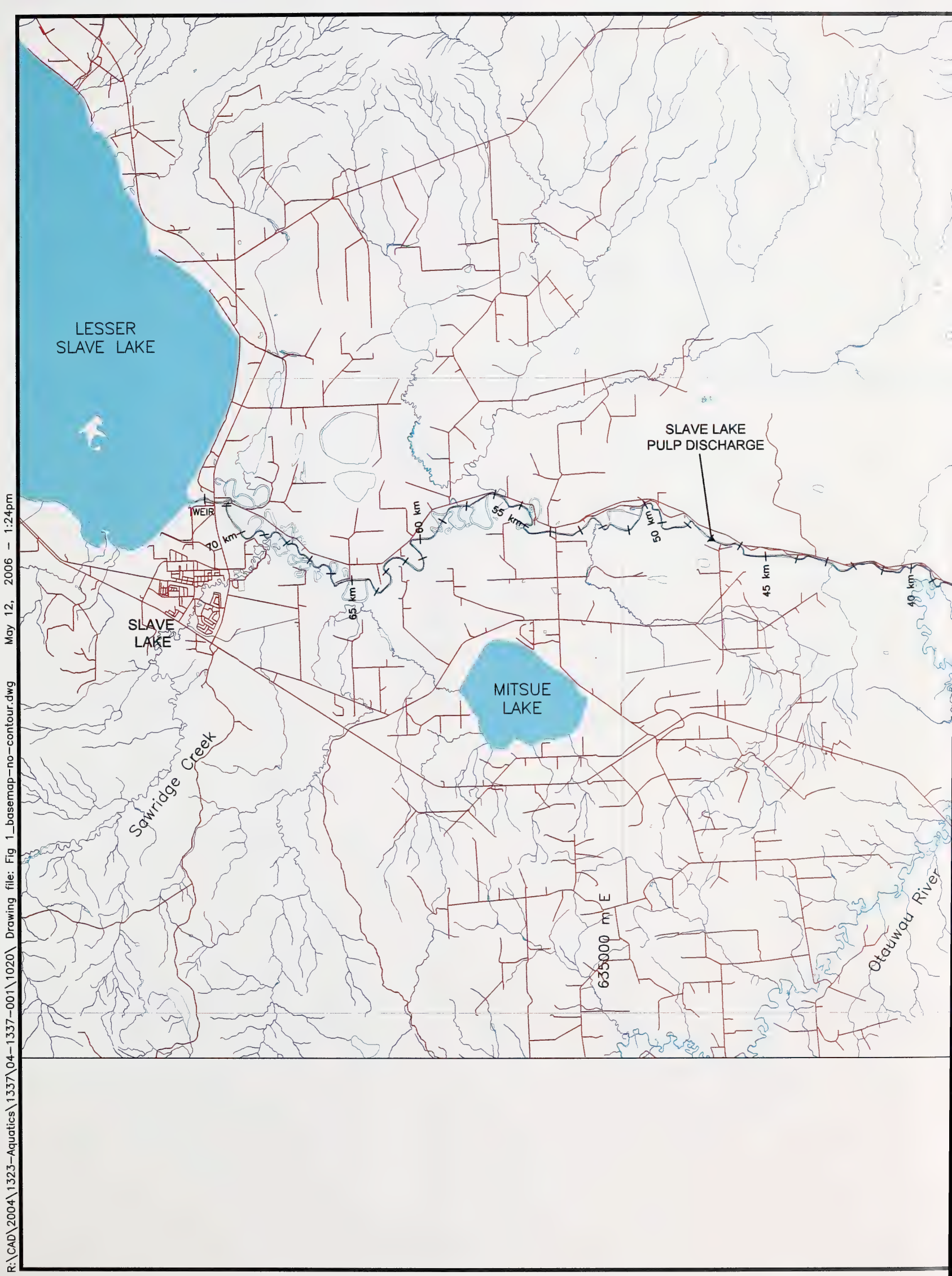



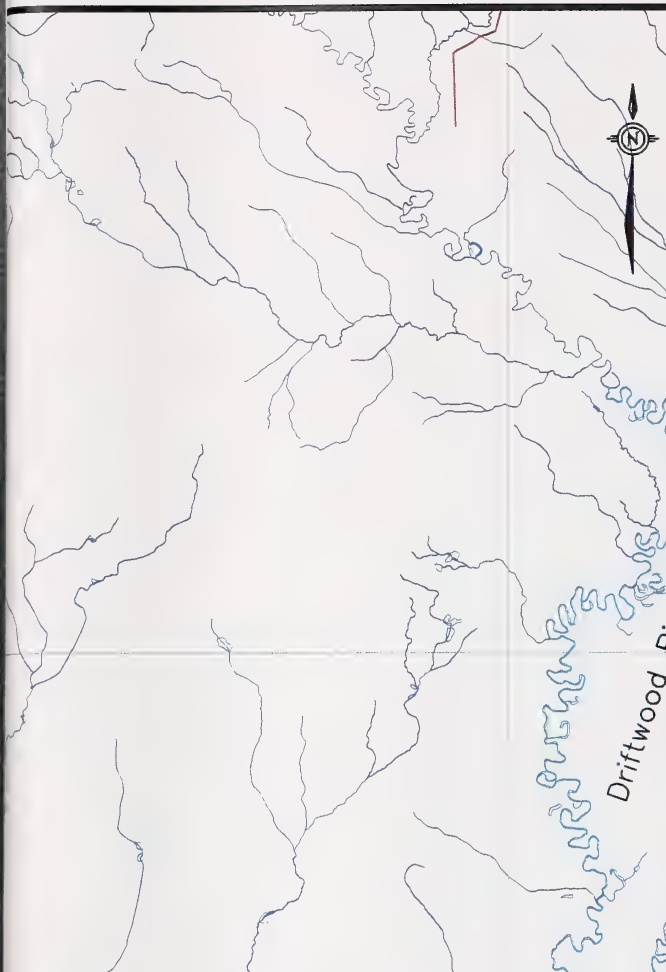

s.
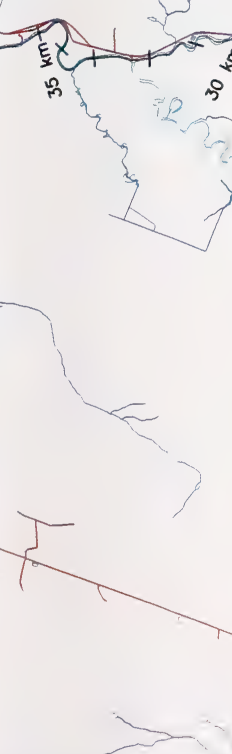

\section{ALBERTA}

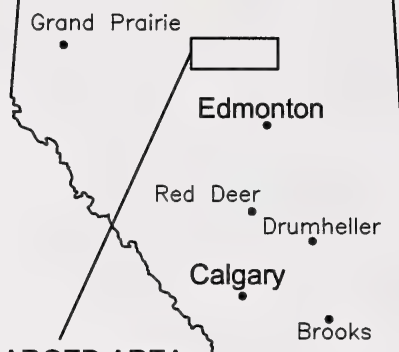

ENLARGED AREA 
- review and summarize existing data;

- identify potential data gaps necessary for completing an IFN evaluation;

- provide a work plan for completing any additional field work and the development of an IFN determination for the Lesser Slave River; and,

- propose a flow evaluation framework for assessing year-round instream flow needs.

Annear et al. (2002) identified five main ecosystem components that should be considered in an IFN study: hydrology, channel morphology, water quality, biology, and connectivity. The data review for the Lesser Slave River focused on seven different aspects of the Lesser Slaver River system including hydrology, channel morphology, ice processes, water quality, benthic invertebrates, riparian ecosystems and fish and fish habitat (including connectivity issues). The data review for the Lesser Slave River covers all aspects of the riverine ecosystem necessary for an IFN study as identified by Annear et al. (2002). Government and the published scientific literature were searched for relevant information. Much of the data for the Lesser Slave River were found from government sources including many unpublished reports or memos. The study team relied on members of the IFNTC to provide many of the government references. The objective of the data review was to identify the suitability of existing data for use in an IFN evaluation as well as identify any data gaps that would hinder the completion of a science-based IFN study. No new data analyses were conducted at this point in the scoping process.

The flow evaluation framework and work plan followed from the results of the background review. The type of information required and tools that can be used for an IFN study are dependant on the availability of data and identifying flow-related issues considered to be of concern on the Lesser Slave River. The final IFN evaluation framework will provide water managers with a tool to evaluate current or future water management conditions relative to the recommended IFN condition. The type of information collected and approaches used for an IFN study, such as fish habitat modelling or riparian assessment, are designed to act as a proxy measure for the response of an ecosystem to changes in water management and are not designed to predict exact population response to changes in water management. Many other factors can influence a "healthy" aquatic ecosystem, such as land use practices or fisheries management (harvest) practices, that are not directly incorporated into an IFN study, but must be considered in the overall plan to achieve protection of the aquatic ecosystem. 



\section{BACKGROUND}

\subsection{Instream Flows for the Protection of Riverine Ecosystems}

Recent IFN studies conducted in Alberta have focussed on developing an IFN for rivers based on the natural flow regime and consideration of multiple ecosystem components (Clipperton et al. 2002, 2003). Detailed background reviews outlining the need to include multiple ecosystem components are provided in these studies and are echoed in a recent summary of instream flow needs approaches and methods published by the Instream Flow Council (Annear et al. 2002). The theoretical underpinnings of using the natural flow regime to protect the aquatic ecosystem are provided in Poff et al. (1997) and Richter et al. (1996, 1997). The application of the natural flow regime concept in defining an IFN is gaining wider acceptance and has been applied in a number of different jurisdictions outside of Alberta including:

- Trinity River, California (USFWS and Hoopa Valley Tribe 1999);

- Klamath River Basin, California (Hardy and Addley 2001);

- Colorado River (Muth et al. 2000);

- Columbia River (Independent Scientific Group 2000);

- South Africa (Brown and King 2002);

- Southeast Australia (Arthington et al. 1991);

- Nooksak River, Washington (Hardy 2000); and,

- Mokelumme River, California (McGurk and Paulson 2002).

Incorporating multiple ecosystem components and using the natural flow regime as a benchmark condition in defining a water management plan for a basin are becoming the standard by which IFN studies are being conducted.

\subsection{Winter IFN Approaches in Other Jurisdictions}

The winter season can be a stressful and limiting period for aquatic biota in north-temperate climates. Studies directed at understanding winter biology have been surprisingly sparse considering river-ice conditions persist for four to six months of the year in many parts of Canada, Alaska as well as in many northern or high elevation rivers within the contiguous United 
States. A summary of recent winter fisheries studies indicates that habitat for fish, juvenile salmonids in particular, is often limiting in winter and these conditions can be exacerbated by human activates (Cunjak 1996). Conclusions from several studies seem to indicate that winter habitat use is different from open-water habitat use (Zafft et al. 1995, Cunjak 1996, Maki-Petays et al. 1999, Whalen et al. 1999) and therefore applying habitat suitability criteria collected under open-water conditions is not valid. Work in Alaska in recent years has looked at the selection of overwintering habitats by fish (Bendock and Bingham 1998, Lubinski 2000, DeCicco 2001), but none of the studies were designed to define under-ice microhabitat conditions.

The Instream Flow Council identified ice processes and related influences on aquatic habitats and organisms as one of the major data gaps where research is needed to improve IFN studies in the future (Annear et al. 2002). The need to include winter conditions in IFN studies has been recognized as a data gap for over 20 years; however, widely accepted tools for this purpose still have not been developed specifically for the winter period. Some approaches that have been proposed include developing regression equations to define the extent to which ice formation excludes useable habitat relative to open-water conditions (Johnson et al. 1982), and applying an adjustment factor to open-water PHABSIM hydraulics to account for winter conditions (Ashton 1990). Some initial testing to include an ice cover with the SSIIM two-dimensional model to simulate winter habitat conditions has been investigated in Norway, although a useable tool that has been applied and tested is still not available ( $\mathrm{K}$. Alfredsen, pers. comm.). It has been speculated that in many river systems the winter period may be the limiting factor for fish populations, but to date there continues to be a lack of suitable habitat assessment tools to address ice-covered conditions (Cunjak 1996, Alfredsen and Tesaker 2002).

Although habitat modelling tools are not available for ice-covered conditions, northern jurisdictions have addressed the winter period by using a variety of methods. In Alaska, where most rivers experience extended ice-covered periods, the Tennant Method (Tennant 1976) has been widely applied since 1986 to quantify instream flow requirements, including the winter period (Estes 1998). In New Brunswick, the 50\% monthly exceedence flow (i.e., the median monthly flow) has been applied as a winter IFN condition (D. Caissie, pers. comm.). In Quebec, an approach has been applied where open-water fall spawning habitats are modelled and the winter IFN is defined based on maintaining the late fall habitat throughout the winter (M. Leclerc, pers. comm.). This approach has been applied to rivers controlled by hydroelectric dams and 
steady flows can be maintained throughout the winter. In the case of the Rupert River, the final IFN determination was $20 \%$ of mean annual flow, which is similar to the winter office approach in Quebec which uses $25 \%$ of mean annual flow as the winter IFN (Belzile et al. 1997). A similar fall spawning approach has also been applied in Alaska (C. Estes, pers. comm.).

An IFN workshop held for the Northern River Basins Study (NRBS) reviewed a number of options for conducting IFN studies on large northern rivers but focussed on two-dimensional hydraulic modelling and remote sensing as the most promising approaches (Walder 1996). At the time of the NRBS workshop (held in October 1993), the consensus was that a one-dimensional hydraulic modelling approach was not feasible due to the complexity of large rivers, logistics problems with data collection and data management. Applying a two-dimensional hydraulic modelling approach was not pursued at the time due to the early stage in development of twodimensional models for habitat evaluations and the limited computer capabilities of the day that restricted spatial extent of a study site. Winter conditions were also identified as a major concern at the NRBS workshop, but potential evaluation options were not identified. The final recommendation from the workshop proposed a remote sensing approach to map and directly measure the changes in habitats at different flows. Although it may have been the most feasible approach at the time, this method was considered to have limited flexibility in evaluating different flow regimes not directly mapped as well as possibly encountering difficulties in interpretation with a constantly shifting sand-bed river, and, would be of no use for ice-covered conditions.

Recent and ongoing research efforts are beginning to shed more light on the issue of winter habitat use and under-ice habitat modelling. Winter IFN work on the Athabasca River has highlighted the difficulty of collecting fish habitat use data under ice (R.L.\&L./Golder 2003). Attempts are also being made to conduct under-ice habitat modelling as a component of the Athabasca River IFN (Golder 2004). Academic-based research defining winter habitat conditions and winter modelling approaches is underway in Wyoming (T. Annear, pers. comm.) and in Norway in conjunction with the University of New Brunswick and Fisheries and Oceans Canada in Newfoundland (K. Alfredsen, pers. comm.). Any attempts currently underway to conduct under-ice habitat modelling should be considered research rather than a component of the widely accepted water management tools that are available for IFN analyses during open-water conditions (e.g., PHABSIM). 



\section{SEGMENTATION ANALYSIS}

Definition of the Study Area and delineation of river segments within the Study Area are critical components to any IFN study. The river segment is the basic habitat unit for defining instream flows and evaluating the available habitat under alternative flow management conditions (Bovee et al. 1998). The key features of a river segment are homogeneity of flow regime and channel geomorphology that makes the segment distinct from adjacent segments. The flow and channel characteristics at the top of a segment at any time of the year should be similar to the characteristics at the bottom of the segment (Bovee et al. 1998). Biological considerations such as species distribution, and physical characteristics such as water temperature regime, can also be used for segment boundary delineation. Point sources of contamination or thermal effluent may also be considered to define segment boundaries; even where the contribution to water supply is not substantial. Bovee (1982) outlines the typical conditions for defining segment boundary locations, which are summarized below.

Segment delineation based on changes in the flow regime are typically defined where the water supply changes significantly, such as at major tributary confluences or major diversions. As a rule of thumb, a significant change in water supply can be considered as an accretion or depletion in the average base flow of the river that is greater than $10 \%$. River segmentation based on flow regime will incorporate some aspects of channel morphology changes but not all of them. Channel morphology is also influenced by slope, sediment supply, bank materials and vegetation. Segment boundaries are placed at sites of abrupt changes in channel morphology which result in a change in the habitat characteristics of the stream or river. Where changes in channel morphology are more subtle or gradual, placement of segment boundaries may be somewhat arbitrary, based on the distinctiveness of the majority of geomorphic characteristics. Segment boundaries are also placed wherever the confinement of the stream changes, where there is a change in sinuosity (the ratio between channel length and valley length), or where the channel pattern (i.e., straight, meandering, or braided) changes.

\subsection{Segmentation Methods}

River segmentation was carried by examination of 1:50 000 NTS topographic maps to evaluate changes in slope and channel form. Digital Elevation Model (DEM) data provided by Alberta 
Sustainable Resource Development were examined to identify changes in river slope from the lake to the Athabasca River. The hydrology summarized in Section 4.1 was used to identify locations along the Lesser Slave River where increases in flow exceeded $10 \%$ of mean annual flow. Channel morphology characteristics of each segment are summarized in Section 4.2 (see Table 6 in Section 4.2). A review of the distribution of fish species in the Lesser Slave River, summarized in Section 4.6, was conducted to identify any shifts in species distribution or critical habitat areas such as migration barriers or spawning habitat. Recent aerial photographs and a video tape recorded during an overflight of the river, provided by AENV, were also examined to identify changes in habitat characteristics.

\subsection{Segmentation Results}

The Lesser Slaver River was divided into five segments for the purpose of conducting the IFN study (Figure 2). Segment 5 was identified as a separate segment due to the presence of the weir and the potential for restricted fish movements past the weir. Habitat conditions as a result of the pooling effect upstream of the weir would be different than downstream habitat. Although this segment is very short, northern pike spawning habitat has been identified in this segment.

Increases in flow occur downstream of the Saulteaux River and downstream of the Driftwood River and segment boundaries have been placed at the confluence of both rivers. Changes in slope, habitat conditions and fish species distribution were also noted at these two locations. Stream slope was derived from 1:50000 NTS maps due to irregularities in the DEM data provided which indicated increasing stream elevation in a downstream direction over a large length of the river. A segment boundary was placed at the Tollenger Road Bridge (formerly Highway 2A) due to changes in channel morphology and water quality. The segment upstream of this point has been modified by cutting off meander bends in the river as part of the Lesser Slave Lake stabilization project and pulp mill effluent enters the river and alters the water quality within this segment. There was some evidence that fish distribution and habitat conditions may be different below the Otauwau River; however, the limited amount of data available was not definitive. The Otauwau River confluence is likely the beginning of the transition from the flatter upstream reaches to the higher gradient reaches below the Saulteaux River. Until more data are available, an additional segment boundary at the Otauwau River was not warranted. 


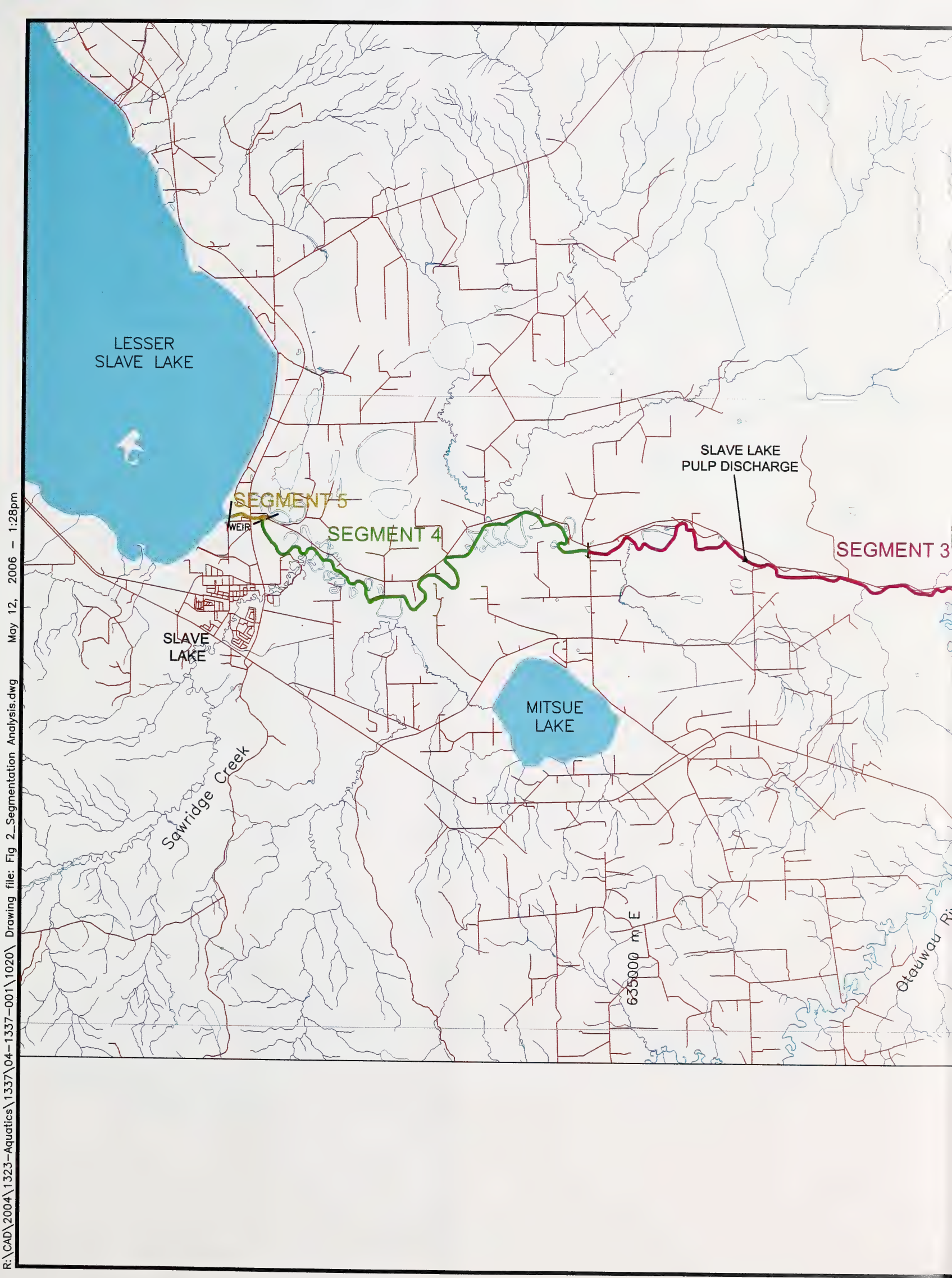





\section{LESSER SLAVE RIVER ECOSYSTEM COMPONENT BACKGROUND SUMMARIES}

\subsection{Hydrology}

The mainstem of the Lesser Slave River runs from the outlet of Lesser Slave Lake to the confluence with Athabasca River. A water management project designed to regulate water levels in Lesser Slave Lake resulted in the construction of a fixed-crest weir at the outlet of the lake in 1982 and a series of channel cutoffs extending approximately $16 \mathrm{~km}$ downstream from the weir and has achieved the desired stabilization of lake levels (Appendix I). The effect of the lake stabilization project on downstream river flows was not directly considered in the design of the project (M. Seneka, pers. comm.).

\subsubsection{Data Availability}

Flows in the mainstem of the Lesser Slave River have been monitored at two gauging stations: one at the outlet of Lesser Slave Lake (07BK001) and the other near the bridge on Tollenger Road (formerly Highway 2A Bridge, 07BK006). Flows have also been monitored on three of the four major tributaries to the mainstem of the Lesser Slave River: 07BK009 on Sawridge Creek, 07BK005 on Saulteaux River and 07BK007 on Driftwood River. A gauging station (07BK004) was installed on the fourth tributary, Otauwau River, but it operated for only one year (1922). Table 1 provides the gauging and flow monitoring information in the Lesser Slave Lake watershed. Figure 3 illustrates the periods of record at each of the five stations.

Figure 3 shows that the two stations on the mainstem have no overlapping period of record. Initial gauging of the Lesser Slave River at 07BK001 began in 1916 and continued until 1939 with a data gap of five years $(1931$ - 1935). Flow data at the outlet of Lesser Slave Lake (07BK001) are then available from 1989 onwards (except for 1997) after the weir was in place. Flow data at Tollenger Road (07BK006) are available from 1965 to 1988, with the flows between 1983 and 1988 being regulated by the weir at the outlet of Lesser Slave Lake. Of the three tributaries, flow monitoring started the earliest on Saulteaux River, in 1970. All three tributaries continue to be gauged and are not affected by the regulation at the weir on the mainstem. 

Tab

Gauging and Flow Characteristic

\begin{tabular}{|c|c|c|c|c|c|c|c|}
\hline \multirow[b]{2}{*}{ Station Name } & \multirow{2}{*}{$\begin{array}{l}\text { Station } \\
\text { No: }\end{array}$} & \multicolumn{2}{|c|}{$\begin{array}{c}\text { Drainage Area } \\
\left(\mathrm{km}^{2}\right)\end{array}$} & \multirow[b]{2}{*}{ Period } & \multirow{2}{*}{$\begin{array}{c}\text { Regulation } \\
\mathrm{N}=\text { Natural } \\
\mathrm{R}=\text { Regulated }\end{array}$} & \multirow{2}{*}{$\begin{array}{c}\text { Winter } \\
\text { Monitoring } \\
\mathrm{Y}=\mathrm{Yes} \\
\mathrm{N}=\mathrm{No} \\
\end{array}$} & \multirow[b]{2}{*}{ Jan } \\
\hline & & Gross & Effective & & & & \\
\hline \multirow[t]{2}{*}{ Lesser Slave River at Slave Lake } & \multirow[t]{2}{*}{ 07BK001 } & \multirow[t]{2}{*}{13,600} & \multirow[t]{2}{*}{13,200} & $\begin{array}{c}1916- \\
1939,1961\end{array}$ & $\mathrm{~N}$ & Y & 27.8 \\
\hline & & & & $1989-2002$ & $\mathrm{R}$ & Y & 30.2 \\
\hline \multirow[t]{2}{*}{ Lesser Slave River at Highway 2A } & \multirow[t]{2}{*}{ 07BK006 } & \multirow[t]{2}{*}{14,400} & \multirow[t]{2}{*}{14,300} & $1965-1982$ & $\mathrm{~N}$ & Y & 31.4 \\
\hline & & & & $1983-1988$ & $\mathrm{R}$ & Y & 25.7 \\
\hline Sawridge Creek near Slave Lake & 07ВK009 & 233 & 233 & $1976-2001$ & $\mathrm{~N}$ & $\mathrm{~N}$ & 0.226 \\
\hline Saulteaux River near Spurfield & 07BK005 & 2,600 & 2,570 & $1970-2001$ & $\mathrm{~N}$ & $\mathrm{~N}$ & 0.514 \\
\hline Driftwood River near the Mouth & 07ВК007 & 2,100 & 2,100 & $1971-2001$ & $\mathrm{~N}$ & Y & 0.573 \\
\hline
\end{tabular}

Missing mean monthly mean flows have been "filled in" by a simple decay function based on winter mean monthly flows rec

Figu

Period of Recorded Data at Gauge

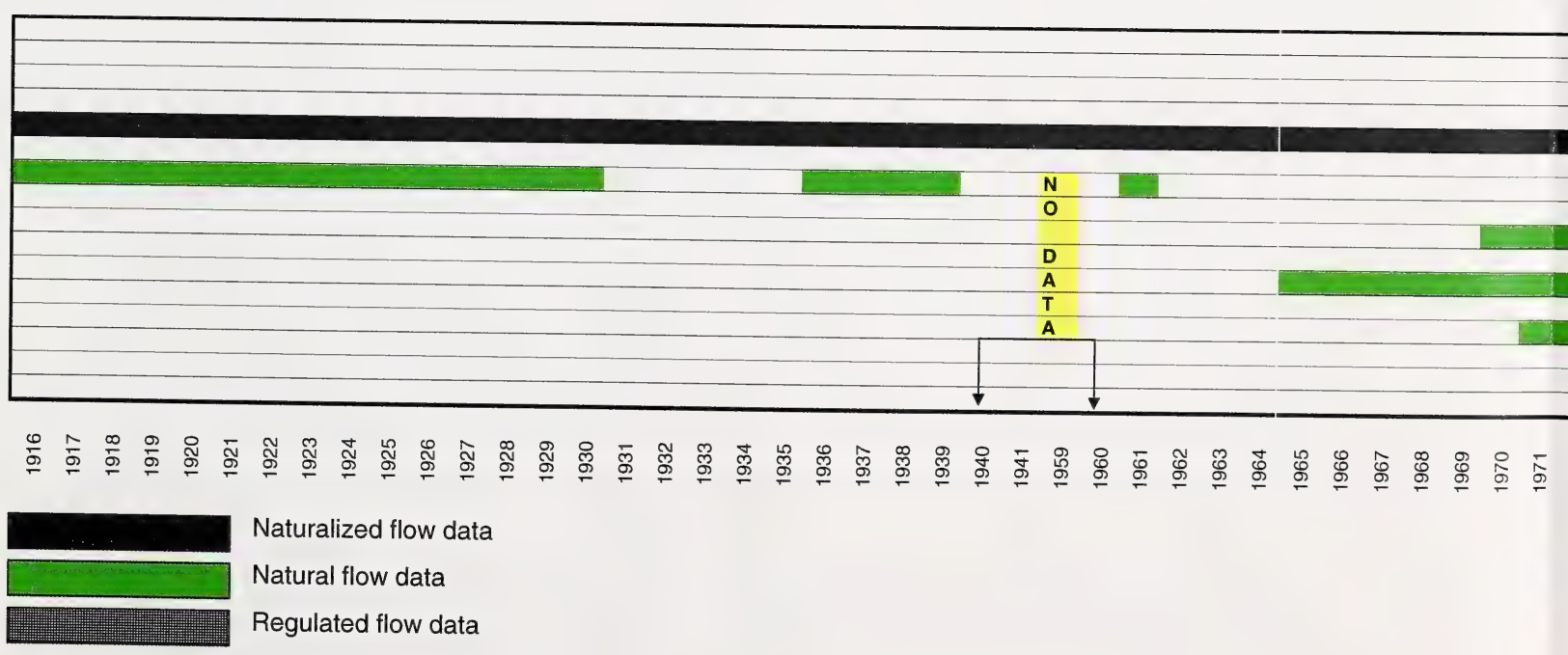


ble 1

is in Lesser Slave Lake Watershed

\begin{tabular}{|c|c|c|c|c|c|c|c|c|c|c|c|c|}
\hline \multicolumn{11}{|c|}{ Mean Monthly Flow $\left(\mathrm{m}^{3} / \mathrm{s}\right)$} & \multirow{2}{*}{$\begin{array}{c}\text { Mean } \\
\text { Annual Flow } \\
\left(\mathrm{m}^{3} / \mathrm{s}\right)\end{array}$} & \multirow{2}{*}{$\begin{array}{c}\text { Mean } \\
\text { Annua } \\
\text { Runof } \\
(\mathrm{mm})\end{array}$} \\
\hline Feb & Mar & Apr & May & Jun & Jul & Aug & Sep & Oct & Nov & Dec & & \\
\hline 27.4 & 29.4 & 33.8 & 44.5 & 55.2 & 60.2 & 57.1 & 50.9 & 45.9 & 36.6 & 29.8 & 41.6 & 96.4 \\
\hline 28.1 & 26.4 & 27.3 & 36.3 & 42.2 & 46.3 & 44.1 & 37.9 & 31.1 & 24.7 & 23.3 & 33.2 & 76.9 \\
\hline 32.2 & 37.3 & 51.1 & 65.6 & 70.0 & 75.1 & 69.5 & 66.5 & 60.6 & 48.6 & 33.5 & 53.4 & 117 \\
\hline 27.2 & 28.1 & 35.6 & 47.0 & 57.7 & 65.8 & 63.5 & 55.3 & 48.8 & 36.5 & 28.4 & 43.3 & 94.8 \\
\hline 0.188 & 0.193 & 2.31 & 3.91 & 3.90 & 3.51 & 1.79 & 1.68 & 1.00 & 0.49 & 0.24 & 1.6 & 219 \\
\hline 0.427 & 0.439 & 11.6 & 20.9 & 20.4 & 27.0 & 12.2 & 7.31 & 4.12 & 2.0 & 1.0 & 9.0 & 109 \\
\hline 0.476 & 0.489 & 7.05 & 17.0 & 17.4 & 19.6 & 9.57 & 6.05 & 3.77 & 1.86 & 0.92 & 7.1 & 106 \\
\hline
\end{tabular}

zorded at Saulteaux.

ire 3

es in Lesser Slave Lake Watershed

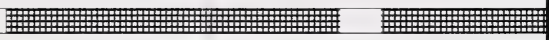

Naturalized Flow (@SL)

$07 \mathrm{BK} 001$ (@SL)

07BK005 (Saul.)

07BK006 (@Hwy2A)

$07 B K 007$ (Drif.)

07BK009 (Sawr.)

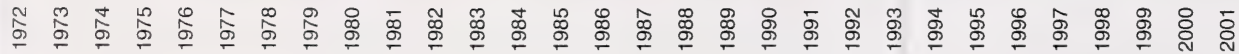




\subsubsection{Hydrologic Analysis Based on Recorded Flows}

Table 1 shows the mean monthly flows at the five gauging stations estimated from the recorded daily flows. The information at 07BK001 and 07BK006 has been provided for the periods prior to and during the flow regulation by the weir. Saulteaux River and Sawridge Creek are not monitored during the winter months. The mean monthly flows at these two stations were estimated by using a simple average decay function based on the mean monthly flow trends observed on Driftwood River during the winter months.

The mean annual runoffs from the two major tributaries, Saulteaux and Driftwood rivers, average about $108 \mathrm{~mm}$. The drainage areas of the two tributaries at the gauging stations are comparable at $2,600 \mathrm{~km}^{2}$ and $2,100 \mathrm{~km}^{2}$, respectively. In contrast, the mean annual runoff from Sawridge Creek is $209 \mathrm{~mm}$, or almost twice the yield from the other two tributary sub-basins. The drainage area of Sawridge Creek at the gauging station is $233 \mathrm{~km}^{2}$. The lengths of record at the three stations are roughly similar and cover the same time period. A review of the topography of the watersheds indicates that Sawridge Creek lies at the southern edge of high relief upland grounds, whereas, the basins of both Saulteaux and Driftwood rivers are lowlands. It is postulated that the orographic effects due to the high relief of the Sawridge Creek Basin contribute significantly to the much higher yield from this basin.

The mean annual runoffs estimated from the data at the two gauging stations on the mainstem of the Lesser Slave River (07BK001 and 07BK006) are about $96 \mathrm{~mm}$ and $117 \mathrm{~mm}$, respectively, for the 'natural flow' portion of the record. The mean annual runoffs are $77 \mathrm{~mm}$ and $95 \mathrm{~mm}$ for the 'regulated flow' portion of the record. The differences are due to (1) short records for the estimation of mean annual runoff ( 6 years for the regulated portion at 07BK006, 12 years for the regulated portion at 07BK001), and (2), wet and dry hydrologic cycles. The natural flow data at 07BK001 cover the period from 1916 to 1930 and 1936 to 1939, which is part of a wet cycle (see Figure 4), while the regulated portion of flow data at 07BK001 is in a dry cycle (see Figure 4).

Due to the lack of a single continuous recorded flow data set on the mainstem of Lesser Slave River, there is a need for a consistent natural and regulated flow series to characterize flows along the mainstem. 

Figu

Naturalized Daily Flows Dow

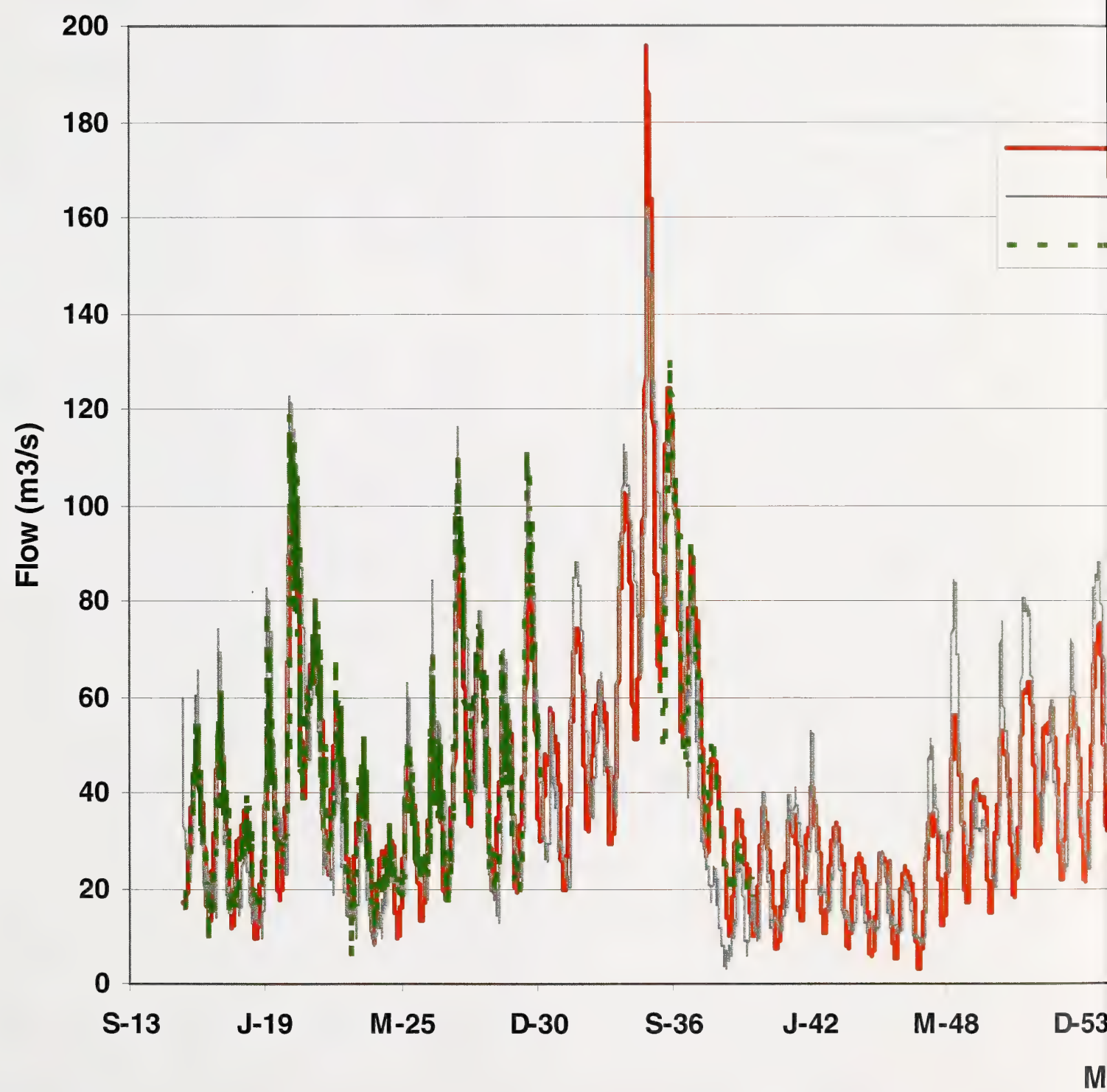


Ire 4

nstream of Lesser Slave Lake

\section{- Naturalized}

\section{- Regulated}

\section{: Recorded @ 07BK001}

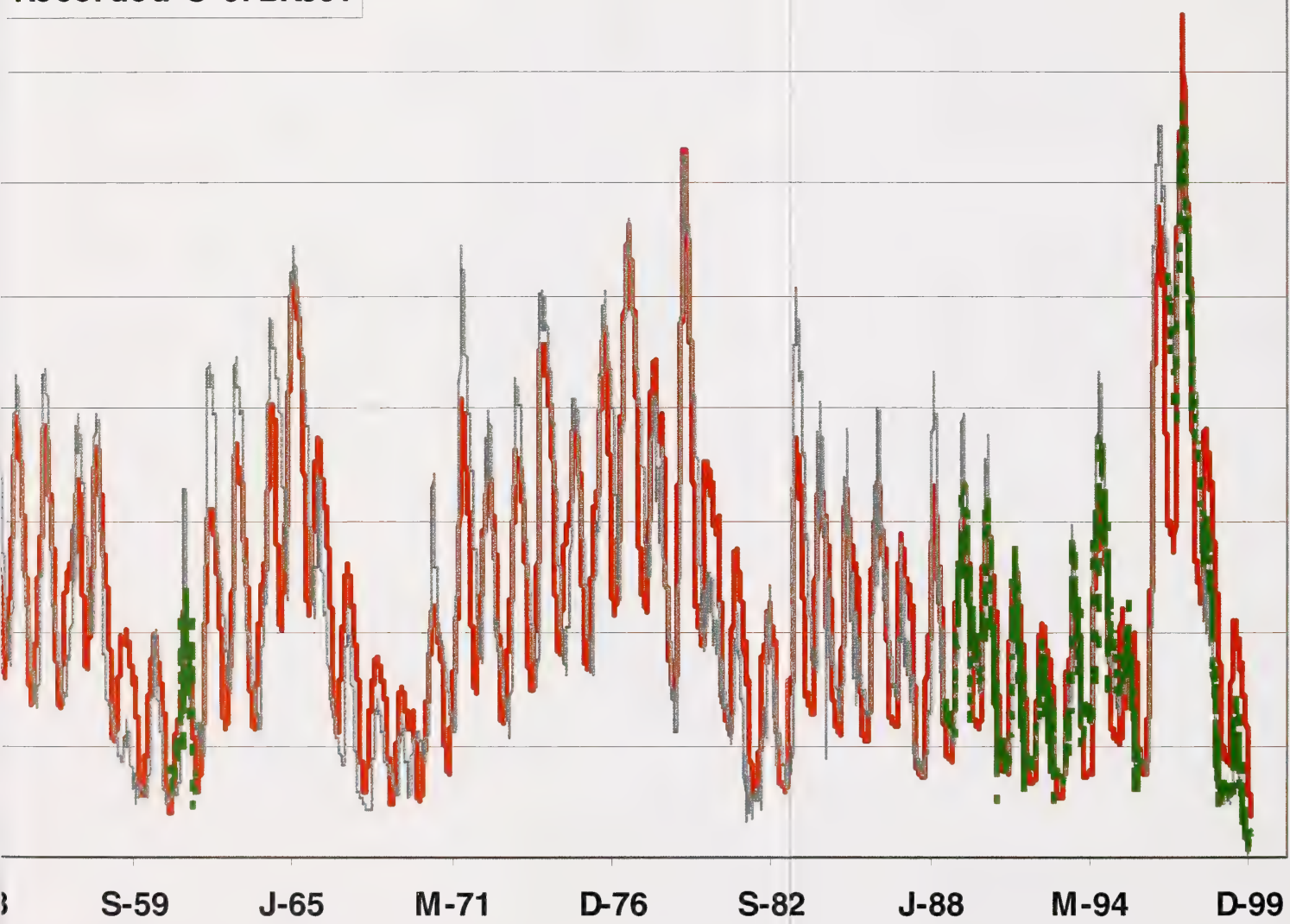




\subsubsection{Naturalized Flows}

Since 1983, flow data on the mainstem of the Lesser Slave River reflect the effects of regulation by the weir. Natural flow series, unaffected by regulation, are required for setting instream flow needs (IFNs) of streams. AENV has developed a "naturalized" series of flow data, from 1916 to 1999, for a location at the outlet of Lesser Slave Lake. The naturalization was based on a mass balance approach using the SSARR model for the catchment area upstream of the lake outlet. AENV also developed a corresponding series of regulated flows from 1916 to 1999, based on the known characteristics of the weir. This is a synthetic flow series derived assuming that the weir has been present since 1916.

Figure 4 shows a plot of the two synthetic series together with the recorded flow data at 07BK001. There is generally good correspondence between the synthetic regulated flow series and recorded flow series (post-1982), and between the naturalized flow series and the recorded flow series prior to regulation (pre-1940), although some differences are apparent suggesting improvements to the synthesized flow series may be possible. A thorough review of the application of the SSARR model and the synthesized flow series developed by AENV was not part of the current scope of work.

Figure 4 also shows that several dry and wet hydrologic cycles have occurred between 1916 and 1999. Except for a few wet years in the mid-1990s, the period between 1983 and 1999 (i.e., after regulation by the weir) has been generally dry. The 1970 s were generally wet years. The flows recorded on the tributaries cover both the wet and dry cycles. Hence, mean annual runoffs derived from their flow series are more likely to represent typical yields. The flow data on the mainstem, especially when separated into natural and regulated portions, fall into either one wet or one dry cycle, and may therefore not represent typical yields.

\subsubsection{Hydrologic Analysis Based on Naturalized Flows}

The naturalized and regulated flow series developed by AENV were used to characterize the hydrology of Lesser Slave River along the segments identified in Section 3. The series from 1970 to 1999 was used for the analysis since the flows at each segment boundary require the inputs from the tributaries and the flow series from the latter start in 1970 at the earliest. A 
comparison of an extended flow time series (1916-1999) and a shortened time series (1970-1999) at the outlet of the lake indicates the 1970-1999 time series is slightly wetter than the 1916-1999 time series, although the pattern of flow is quite similar (Appendix I). No specific guidance is provided for the length of flow time series required for an IFN study beyond two general recommendations that a longer time series is always preferred and that the final time series must incorporate typical conditions (Bovee et al. 1998). A series of 30 years is considered adequate for the objectives of the present work and includes both wet and dry series as shown in Figure 4, and will be used for all remaining analysis so that flows for each segment can be incorporated. The use of the two 30-year synthetic flow series (natural and regulated) provides a good indication of hydrologic changes expected as a result of the flow regulation by the weir.

The Lesser Slave River was divided into four segments below the weir for the purpose of assessing IFNs. The segmentation was determined such that there is not more than a $10 \%$ increase in the mean annual flow from the upstream segment boundary node to the downstream segment boundary node. The hydrology above the weir was not included in the current review.

\subsubsection{Mean Monthly Flows}

Table 2 shows the drainage areas at the nodes of the four reaches of the mainstem below the weir, as well as the mean monthly flows estimated from the naturalized flows at the outlet of Lesser Slave Lake from 1970 to 1999 . Table 3 shows the mean monthly flows estimated from the derived regulated flows at the same location. Drainage areas for each node used in the evaluation were developed by Alberta Environment (memo 7BK, 2002-115).

The flows at nodes downstream of the outlet of Lesser Slave Lake were estimated by adding average flows from the Saulteaux and Driftwood basins prorated on the basis of the incremental drainage area downstream of the outlet of Lesser Slave Lake. The yield from Sawridge Creek is generally twice that from either from Saulteaux or Driftwood rivers. However, the drainage area subject to this enhanced yield is less than $5 \%$ of the increase in drainage area from the lake to the mouth at Athabasca River. Hence, the effect of neglecting the high yield from Sawridge Creek on the flows in the mainstem is considered to be negligible and acceptable for the present scope of work. 

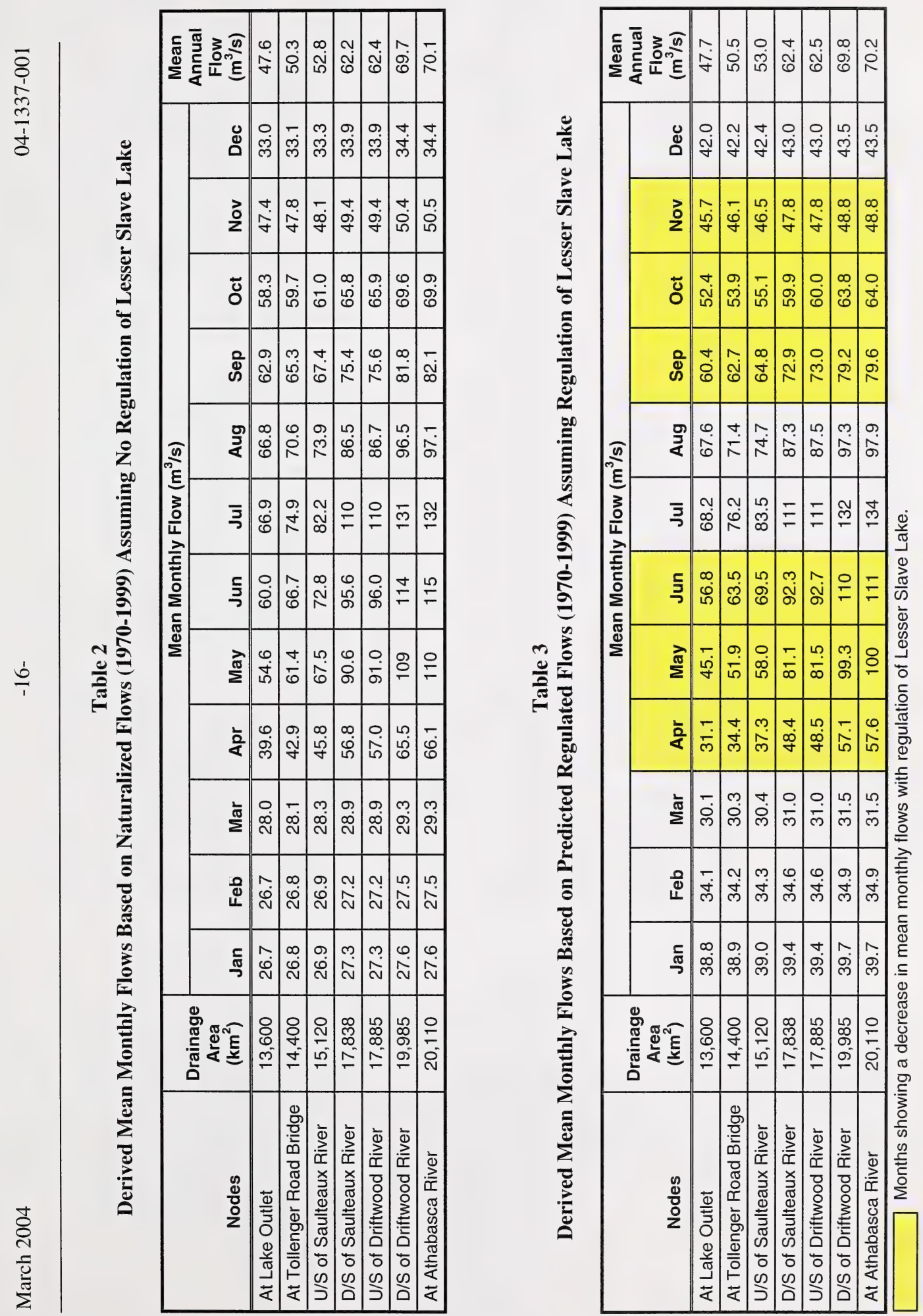

A comparison of Tables 2 and 3 suggests that, over the long term, regulation by the weir will decrease mean monthly flows during the spring months (April, May and June) and the fall months (September, October and November). The decrease occurs primarily because of additional storage possible with the presence of the weir. Otherwise, one can expect an increase in mean monthly flows due to regulation at other times of the year. There is very little change in mean annual flows between the natural and regulated flow regime.

\subsubsection{Flow Duration Curve}

Figure 5 shows the flow duration curves obtained from the daily flows derived from the naturalized flows at the outlet of Lesser Slave Lake from 1970 through 1999. Duration curves for the downstream segments were created using a proration based on drainage area and flows on Saulteaux and Driftwood rivers. This illustrates the change in hydrology within each segment. To create an extended period of record for each segment similar to that available at the outlet of the lake (1916 to 1999), a synthesized natural flow record prior to 1970 for each of the major tributaries would be required.

Using the 1970 to 1999 data, a daily flow duration curve at the outlet of the lake was created to compare naturalized versus regulated flows (Figure 6). This illustrates the effect of the regulated flow regime in the Lesser Slave River in that high flows are increased and low flows decreased. The flow duration curve downstream of Saulteaux River (Figure 7) indicates the effects of the weir are still noticeable downstream; however, the magnitude of effect between the naturalized and regulated flow regime is attenuated as a result of tributary inflows.

\subsubsection{Flood Flows}

An analysis of annual maximum daily flows extracted from the naturalized and regulated (synthetic) series (1970 to 1999) suggests that the 2-year to 10-year flood flows would be expected to increase under a regulated flow regime. The results of the frequency analysis are provided in Table 4. Flood flows of higher return periods are expected to decrease. This change is important because flows that generally form and control channel shape and morphology usually have a return period between 2-years and 10-years. 

Figure 5

Daily Flow Exceedence Curves on Lesser Slave River, 1970-1999

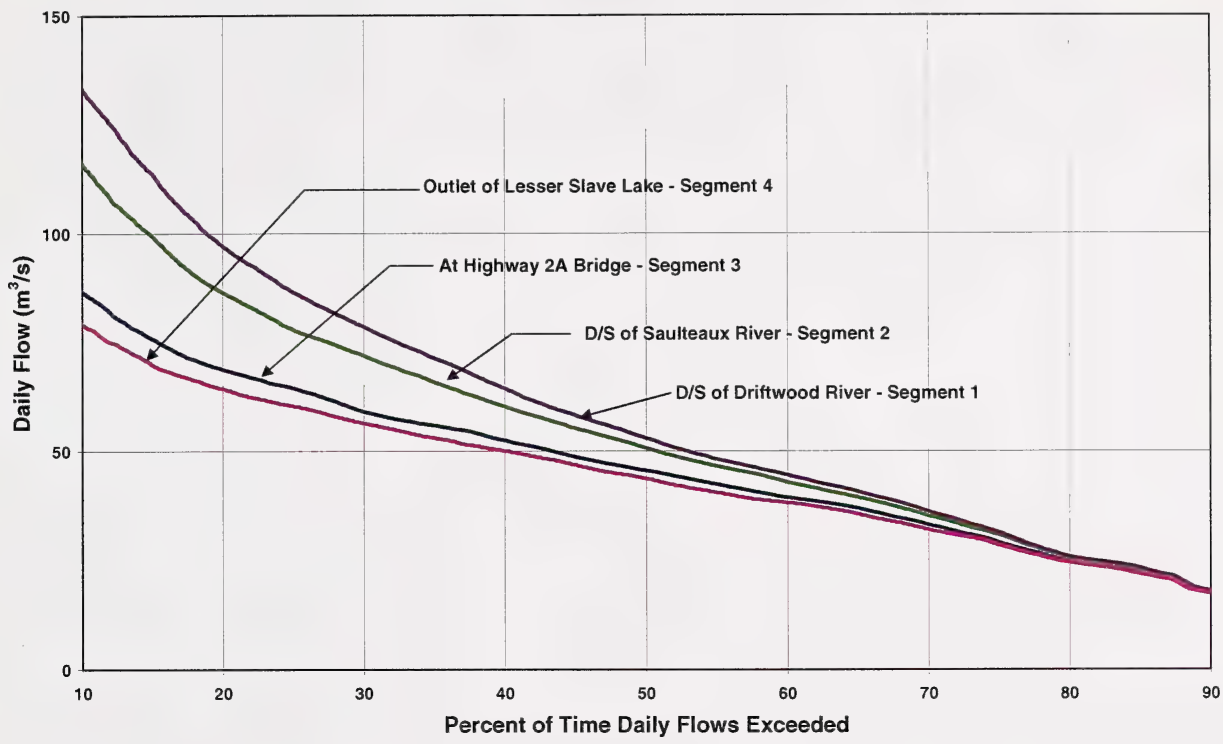

Figure 6

Comparison of Naturalized versus Regulated Flow Exceedence Curves at Lesser Save Lake Outlet, 1970 - 1999

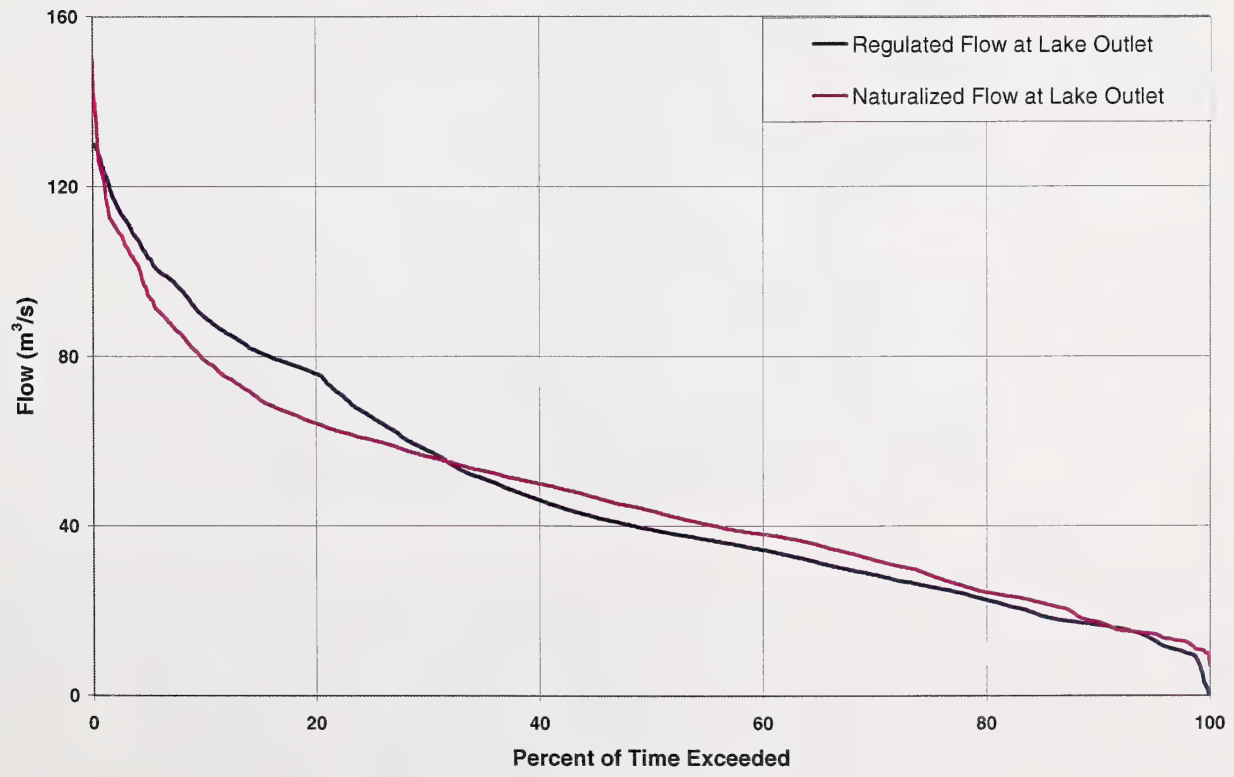



Figure 7

Comparison of Naturalized versus Regulated Flow Exceedence Curves

Downstream of the Saulteaux River, 1970 - 1999

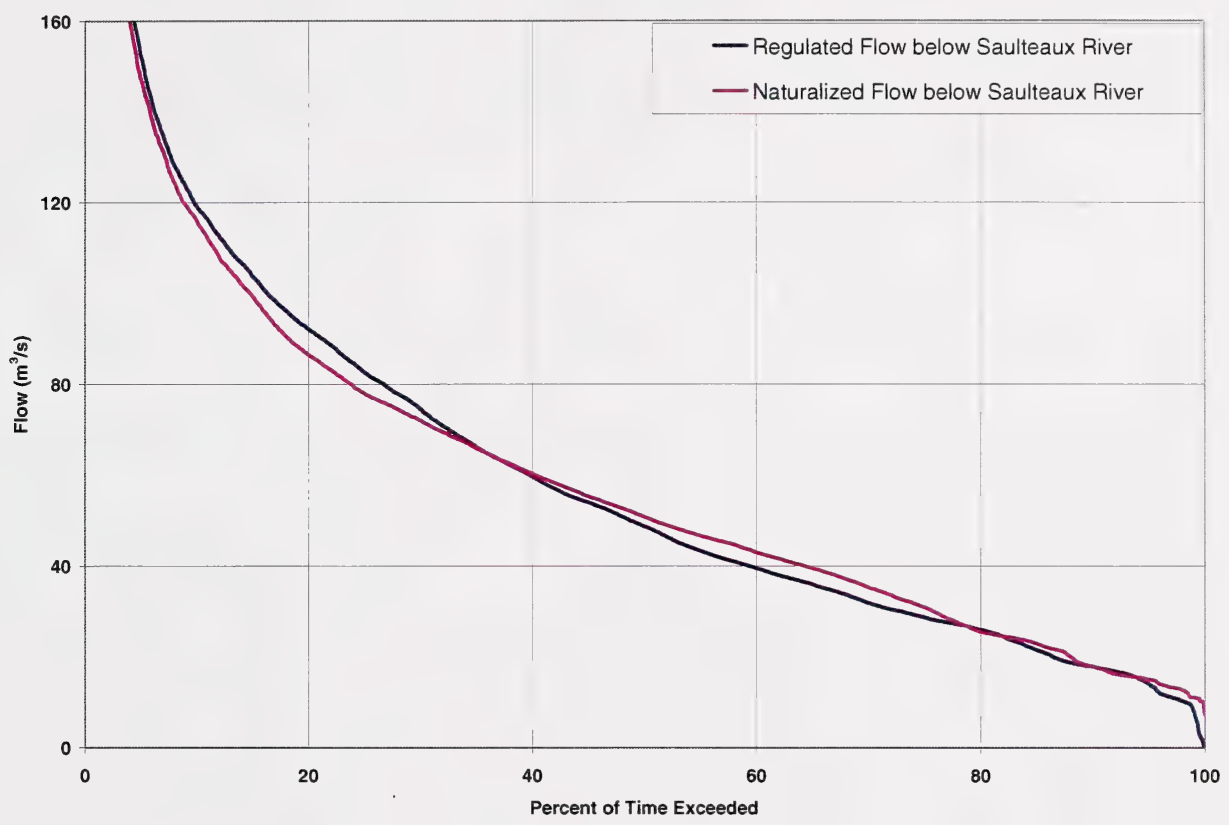

Table 4

Flood Flows at the Outlet of Lesser Slave Lake Based on Naturalized and Regulated Flows (1970-1999)

\begin{tabular}{|c|c|c|}
\hline T-Year & $\begin{array}{c}\text { Naturalized Flood } \\
\text { Flow }\left(\mathbf{m}^{3} / \mathbf{s}\right)\end{array}$ & $\begin{array}{c}\text { Regulated Flood } \\
\text { Flow }\left(\mathbf{m}^{3} / \mathbf{s}\right)\end{array}$ \\
\hline 2 & 66.9 & 79.5 \\
\hline 5 & 90.0 & 102 \\
\hline 10 & 107 & 114 \\
\hline 25 & 131 & 127 \\
\hline 50 & 150 & 136 \\
\hline 100 & 170 & 143 \\
\hline
\end{tabular}

The weir was designed to have a low tail-water level and to be very efficient, which means that during moderate floods the weir is discharging much more efficiently than under natural conditions. As a result, in combination with the downstream channel straightening, at equal lake levels flows are augmented under the regulated condition relative to the natural condition. At 

high flows, it is expected that the effects of the weir and channel straightening would become negligible and extreme regulated flood flows should tend towards extreme natural flood flows. However, the data indicate a decrease in the extreme flood flows. Notwithstanding the foregoing explanation, a review of the SSARR modelling results and discussion with AENV are warranted to ensure that the naturalized and synthetic regulated series are consistent.

\subsubsection{Low Flows}

An analysis of annual 1-day low flows extracted from the naturalized and regulated (synthetic) series (1971 to 1999) indicates that regulation will increase the 2-year low flow, but decrease the 10 -year and higher return period low flows. Table 5 provides the results of the frequency analysis. A low flow analysis produced by Alberta Environment using recorded flows indicate a $7 \mathrm{Q} 10$ flow of $7.2 \mathrm{~m}^{3} / \mathrm{s}$, down from a previously calculated value of $11.6 \mathrm{~m}^{3} / \mathrm{s}$ (Seneka 2000). It was suggested by AENV that the lowering of the $7 \mathrm{Q} 10$ value was a combination of effects of recent low flow years and the influence of the weir on the flow regime. The low flow analysis shown in Table 5 was conducted using a log_Pearson Type III frequency distribution for the naturalized flows and a 3-parameter log-normal frequency distribution for the regulated series. The process of naturalization using the SSARR model may introduce some errors in simulated flows of relatively short durations such as the 1-day low flows. A review of the naturalized minimum 1-day low flows and a comparison with recorded minimums, both in terms of magnitude and timing, is recommended to ascertain that the naturalized series replicate the observed data.

Table 5

Low Flows at the Outlet of Lesser Slave Lake Based on Naturalized and Regulated Flows (1971-1999)

\begin{tabular}{|c|c|c|}
\hline T-Year & $\begin{array}{c}\text { Naturalized 1-Day } \\
\text { Low Flow }\left(\mathrm{m}^{3} / \mathrm{s}\right)\end{array}$ & $\begin{array}{c}\text { Regulated 1-Day Low } \\
\text { Flow }\left(\mathrm{m}^{3} / \mathrm{s}\right)\end{array}$ \\
\hline 2 & 18.1 & 24.5 \\
\hline 10 & 10.6 & 7.1 \\
\hline 50 & 8.4 & 1.6 \\
\hline
\end{tabular}




\subsubsection{Recommendations}

The above analysis was based on the naturalized flows provided by AENV. The current naturalized flows were developed using a mass-balance approach within the SSARR model. A thorough review of the methodology, assumptions and results of the application of the SSARR model is recommended prior to use in an IFN analysis. The review will provide an understanding of the accuracy of the naturalized flows, which will help in interpreting observed changes in the current hydrologic regime. The current mass balance approach also does not allow for direct application of the SSARR model and extrapolation of flows at the tributary nodes. Alternate approaches, such as applying a regression approach or using the HSPF model, should be investigated.

The flow series from the tributaries of the Lesser Slave River should be extended back to 1916 to be concurrent and consistent with the naturalized flow series at the outlet of the lake. Naturalized and regulated flow series starting from 1916 could then be created for each segment on the mainstem of the Lesser Slave River. A longer flow time series, which would include multiple wet and dry cycles, will provide statistical estimates with a higher degree of confidence than those from shorter series, particularly since some differences between the longer (1916-1999) and shorter (1970-1999) time series are apparent (see Appendix I). The mass balance method used for naturalization at the lake outlet flows restricts the options for extending the time series for the tributaries. Extending the tributary flows data back to 1916 using the current set of naturalized flows would have to be done using a regression approach. This approach may not provide daily or even weekly flows with any degree of accuracy. Applying a modelling approach that accounts for precipitation and topographic information would allow for a more detailed extrapolation of flows with estimates of daily flows possible.

An analysis of precipitation data is also necessary to confirm that differences noted in mean annual runoff can be attributed to wet and dry cycles. 


\subsection{Channel Morphology and Ice Processes}

\subsubsection{Overview}

Changes in flow regime have the potential to alter the physical form and structure (morphology) of any river channel. Thus, for this IFN study it is important to be aware of the various morphological processes that take place under both open-water and ice-cover conditions that could be affected by changes in flow.

Ongoing natural processes such as sediment transport, erosion and deposition are primarily responsible for the evolution of the Lesser Slave River into its present day form. However, manmade alterations have affected the channel characteristics in the upper reach and have the potential to interfere with the ongoing natural processes. The overall river slope is largely controlled by the presence of cobble-paved bed at Saulteaux Rapids ( $48 \mathrm{~km}$ downstream of lake) and by the lake itself (Northwest Hydraulic Consultants Ltd. 1984).

The physical characteristics of the Lesser Slave River channel vary from reach to reach as described below and summarized in Table 6.

\section{Segment 5 (Lesser Slave Lake to Weir)}

This short segment extends from the natural lake outlet to the existing outlet control weir, a distance of about $1.4 \mathrm{~km}$. The channel bed is predominantly composed of sand originating from Lesser Slave Lake (littoral drift material). The average channel width is about $60 \mathrm{~m}$. The channel bottom may be slowly aggrading in this segment as a portion of the sediment load from the lake is trapped by the weir. Typically, the depth of flow in this section of channel will have increased and the flow velocity will have decreased somewhat over natural (pre-weir conditions) due to the backwater effects created by the weir. 
Table 6

Geomorphic Characteristics of the Lesser Slave River ${ }^{1}$

\begin{tabular}{|c|c|c|c|c|c|}
\hline Parameter & $\begin{array}{l}\text { Segment } 1 \\
\text { (Driftwood to } \\
\text { Mouth) }\end{array}$ & $\begin{array}{l}\text { Segment } 2 \\
\text { (Saulteaux to } \\
\text { Driftwood) }\end{array}$ & $\begin{array}{c}\text { Segment } 3 \\
\text { (Tollenger Road } \\
\text { to Saulteaux) }\end{array}$ & 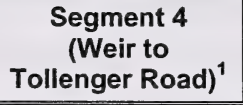 & $\begin{array}{c}\text { Segment } 5 \\
\text { (Lake to Weir) }\end{array}$ \\
\hline Slope $(\mathrm{m} / \mathrm{m})$ & 0.0007 & 0.0007 & 0.0001 & $\begin{array}{l}0.00011 \\
0.00014^{3}\end{array}$ & $\mathrm{~N} / \mathrm{A}$ \\
\hline Width $^{2}(m)$ & 100 & 75 & 50 & 46 & 60 \\
\hline $\begin{array}{l}\text { Channel } \\
\text { Pattern }\end{array}$ & $\begin{array}{l}\text { Irregular } \\
\text { meanders }\end{array}$ & $\begin{array}{l}\text { Gentle meanders } \\
\text { straight sections }\end{array}$ & $\begin{array}{l}\text { Gentle meanders } \\
\text { straight sections }\end{array}$ & $\begin{array}{l}\text { Irregular } \\
\text { Meanders } \\
\text { Man-made } \\
\text { cuttoffs }^{3}\end{array}$ & Gentle meanders \\
\hline Sinuosity & 1.8 & 1.1 & 1.5 & 2 & N/A \\
\hline $\begin{array}{l}\text { Lateral } \\
\text { Stability }\end{array}$ & N/A & N/A & Slightly Unstable & Slightly Unstable & N/A \\
\hline Bed Material & Gravel & Gravel & Sand & Deep sand or silt & Sand \\
\hline $\begin{array}{l}\text { D50 Bed } \\
(\mathrm{mm})\end{array}$ & N/A & N/A & N/A & 0.2 & N/A \\
\hline $\begin{array}{l}\text { Bank } \\
\text { Material }\end{array}$ & N/A & N/A & N/A & Silt and sand & N/A \\
\hline
\end{tabular}

${ }^{1}$ From Kellerhals et al. (1972).

${ }^{2}$ Derived from 1:50 000 NTS Maps.

${ }^{3}$ Following construction of channel cutoffs between !980-83.

\section{Segment 4 (Weir to Tollenger Road)}

The upper river segment, which extends from the weir to the Tollenger Road Bridge, has a planform that is characterized by an irregular meander pattern and a series of man-made cutoffs that have substantially increased the reach-averaged channel slope from approximately $0.10 \mathrm{~m} / \mathrm{km}$ to about $0.14 \mathrm{~m} / \mathrm{km}$. The bed and banks are composed of sand and silt and the channel is considered to be only slightly unstable (Kellerhals et al. 1972). The bankfull width typically varies from about 40 to $50 \mathrm{~m}$, and averages about $46 \mathrm{~m}$. Although the information collected by Kellerhals is over 30 years old and predates construction of the weir and channel cutoffs in the early 1980 's, it remains relevant for the most part and provides a baseline for comparison of pre and post regulation conditions. 


\section{Segment 3 (Tollenger Road Bridge to Saulteaux River)}

The segment from the Tollenger Road Bridge to the Saulteaux River is similar to Segment 4 in terms of the natural channel gradient (approximately $0.1 \mathrm{~m} / \mathrm{km}$ ), channel width (approximately $50 \mathrm{~m}$ ), bed and bank composition (sand/silt) and lateral stability. The major difference between segments 4 and 3 lies in the channel planform, which can be described as having a less prominent (gentler) meander pattern, alternating with relatively straight sections.

\section{Segment 2 (Saulteaux River to Driftwood River)}

Segment 2 below the Saulteaux Rapids is distinguished from the upper two segments by a marked increase in channel gradient below the Saulteaux Rapids (41 km downstream of the lake). The bed slope below the rapids is estimated to be in the order of $0.7 \mathrm{~m} / \mathrm{km}$ as derived from 1:50 000 NTS maps. Although the channel pattern is similar to that of Segment 2 (i.e., gentle meanders alternating with straighter sections), the typical channel width appears to have increased to about $75 \mathrm{~m}$ in Segment 2. The bed material composition, below the cobble paved section at Saulteaux Rapids is predominantly gravel (Alberta Environment 1996).

\section{Segment 1 (Driftwood River to Mouth)}

Based on information derived from 1:50 000 NTS maps and air photos, the lower reach of the Lesser Slave River appears to have a substantially greater channel width (i.e., in the order of 100 $\mathrm{m}$ ) than any of the upper reaches. The channel planform is characterized by an irregular meander pattern (similar to Segment 4), the channel gradient is approximately $0.7 \mathrm{~m} / \mathrm{km}$ and the bed material is believed to be predominantly gravel (similar to Segment 2).

\subsubsection{Sediment Regime}

As stated above, a major factor affecting channel morphology is sediment regime. The following is summarized from Northwest Hydraulics Consultants Ltd. (1984):

The present river from the lake to the Tollenger Road bridge crossing, a distance of about $20 \mathrm{~km}$, has become entrenched within ancient glacial lake bottom sediments. The bed of the Lesser Slave River consists of sand that is principally derived from Lesser Slave Lake littoral drift 
material transported to the inlet area of the river. This sand exists as a thin layer (average of $1 \mathrm{~m}$ thick) being transported slowly over underlying lacustrine material. Comparison of historic aerial photographs indicates that bank erosion rates are small, so that very little sand material is derived by the bed from the banks. Bed material samples show that sizes of material being transported on the bed vary in range from fine to medium sands $(0.16$ to $0.35 \mathrm{~mm})$.

A surveyed water surface profile in the reach from the lake to Saulteaux Rapids was conducted in August 1977 by Alberta Environment at a discharge of $119 \mathrm{~m}^{3} / \mathrm{s}$. The average slope based on this survey was $0.1 \mathrm{~m} / \mathrm{km}$. Northwest Hydraulics Consultants Ltd. concluded that for this gradient and the range of bed material sizes present, the river should have little capacity for meandering, which appears to be the case downstream of the Tollenger Road bridge crossing where it is essentially a straight channel. Northwest Hydraulics Consultants Ltd. speculated that the reason that the river has developed a series of irregular meander patterns upstream of Tollenger Road may have been a result of the river adjusting to "slugs" of sediment being brought into the system during extreme high lake levels.

Northwest Hydraulics Consultants Ltd. (1984) drew the following conclusions with respect to bed sediment transport rates in the Lesser Slave River based on methods available in the literature:

- Bed material transport starts at about $9.5 \mathrm{~m}^{3} / \mathrm{s}$; a flow-duration curve produced at the time showed that this flow is exceeded almost every day in an average year.

- Bed material is transported in the ripple mode up to about $55 \mathrm{~m}^{3} / \mathrm{s}$, and as dunes thereafter; in an average year this flow was estimated to be exceeded approximately $30 \%$ of the time.

Northwest Hydraulics Consultants Ltd. (1984) further concluded that "although bed material transport by the Lesser Slave River occurred almost continuously, it rarely reaches a rate that might be considered even moderately high. Estimated concentrations at high flows were only about $50 \mathrm{ppm}$. A summary of instantaneous sediment concentration and discharge data collected at gage 07BK006 from $1984-1988$ by WSC is provided in Appendix I. 


\subsubsection{Impacts from Weir and Channel Cutoff Construction}

Between 1980 and 1983 a total of nine channel cutoffs and an outlet control weir were constructed in the upper reach of the Lesser Slave River, in the first $23 \mathrm{~km}$ below Lesser Slave Lake. The primary purpose of these works is to regulate levels in Lesser Slave Lake. The overall impact of the Lesser Slave Lake Regulation Project is to reduce the range of long-term water level fluctuations and to reduce the frequency of both high and low water levels in the lake.

The following potential impacts of the Lesser Slave Lake Regulation Project were identified in the early post construction assessment by Northwest Hydraulics Consultants Ltd. (1984):

- Channel bed aggradation upstream of the weir due to the influence of the weir on channel hydraulics and a reduced sediment transport capacity.

- Channel bed degradation downstream of weir due to the effect of the cutoffs on channel hydraulics and an increased sediment transport capacity (potentially as much as $1.0 \mathrm{~m}$ after 100 years).

- Minor channel bed aggradation downstream of the cutoffs due to the increased sediment transport rate through the cutoff reach.

- Channel shifting and bank erosion rates should not be substantially different than before regulation due to the anticipated reduction in the flood peak regime and an unchanged annual bed material transport rate.

A later assessment by Alberta Environment (1994) of the effects of the Lesser Slave Lake Regulation Project on channel form and gradient in the affected river reach arrived at the following observations and conclusions, based on a comparison of surveyed channel cross sections from 1984, 1986 and 1994:

- Upstream of the weir: a comparison between the 1984 and 1993 cross sections show that the river channel (thalweg) has shifted towards the right bank (looking downstream) upstream of weir. The surveyed cross sections also indicate that some aggradation has taken place.

- Downstream of the weir: the majority of these sections show that some changes/adjustments in the channel regime have taken place below the weir. Most of 
these adjustments indicate degradation. The cross sections through the cutoffs indicate some local bank erosion at a few locations. The assessment also indicated a general trend toward adjustment of the river channel to its natural shape has been slowly progressing through these cut-offs.

- A comparison of channel bed profiles suggests that over a $17.5 \mathrm{~km}$ length of river channel downstream of the weir, approximately $5.5 \mathrm{~km}$ have shown aggradation, while about $12.0 \mathrm{~km}$ has undergone degradation.

It was concluded that the river channel downstream of the lake outlet has been adjusting to obtain equilibrium conditions.

A more recent assessment by Alberta Environment (1996) of the effects of the Lesser Slave Lake Regulation Project on channel form and gradient in the affected river reach arrived at the following observations and conclusions based on a comparison of 4 sets of surveyed channel cross sections taken between 1984 and 1996:

- A good number of cross sections show that the river channel bedgrade generally degraded during the period from 1984 to 1986, and during the period from 1986 to 1994, the cross sections show a reverse trend indicating that sedimentation has taken place. From 1994 to 1996 the cross sections show no appreciable change in the river channel bedgrade.

- From the analysis, based upon the limited number of years of data, no definite conclusive results could be drawn. The process of change in the river cross sections appears to be very slow. This could be partly attributed to the lack of high flood events since the construction of the weir and the cutoffs in 1984.

\subsubsection{Ice Processes}

Very little information exists with respect to ice formation and breakup processes on the Lesser Slave River. The only formal document known to exist on this subject is a memorandum prepared by Northwest Hydraulics Consultants Ltd. (1980). The information contained in this memorandum was largely based on comments from long-term local inhabitants of the Lesser Slave Lake area, from Water Survey of Canada streamflow records and from a pre-break-up 
reconnaissance on April 3, 1979. The pertinent information from the pre-regulation time period (prior to 1980) is summarized below:

- Lesser Slave Lake typically freezes over around the middle of November (resident comment).

- Ice effects are typically felt in early November at the former streamflow gauging station (07BK006) about $24 \mathrm{~km}$ downstream of the lake (Water Survey of Canada records).

- The upper kilometre of the river usually remains free of a firm ice cover all winter, as a result of the relatively warm water being discharged from the lake (resident comment).

- Major ice jamming apparently does not occur on the river. This was substantiated by the lack of ice damage to trees on the outside of bends and on small islands over the length of the river between the lake and the Saulteaux Rapids (April 1979 observations by Northwest Hydraulics Consultants Ltd.).

- The river and lake are generally ice free by the end of April and middle of May, respectively (Northwest Hydraulic Consultants Ltd. 1980).

During the breakup period, westerly winds can cause lake ice to ground-out on the shallows along the east shore of the lake. It has been reported on at least one occasion (1928), lake ice jammed against the bridge $1 \mathrm{~km}$ downstream of the outlet and temporarily formed an ice dam that restricted outflow (Environment Canada report on Lesser Slave Lake Water Levels 1914-1977).

The Northwest Hydraulics Consultants Ltd. (1980) memorandum assessed the potential impacts of flow regulation on ice formation and breakup conditions and concluded that the "implementation of the cutoffs and a low-flow control weir on the Lesser Slave River can be expected to have negligible effects on the ice regimes of the lake and river". The authors did speculate that "if the winter is extremely cold, ice at the weir could temporarily block the channel, causing the downstream river to drain". However, they concluded that "the possibility of this occurring is considered to be remote".

No information was found relating to how ice process affects channel morphology in general. 


\subsubsection{Effects of Changed Flow Regime}

With reference to Section 4.1 of this report, the preliminary results from the Hydrology review suggest the following:

- There is very little change in mean annual flows when comparing the natural and regulated flow regimes.

- The 2-year to 10-year flood flows would be expected to increase under the regulated flow regime whereas flows for more infrequent floods with return periods greater than 10 years would be expected to decrease.

It is generally accepted, based on "Regime Theory", that for mobile sand-bed rivers the channelforming flows (i.e., the flows that dictate the channel shape, gradient and other morphologic characteristics) usually have a return period between 2-years and 10-years. Thus, a potential impact of flow regulation (based on the above preliminary results) would be for the channel downstream of the lake outlet to undergo some morphologic adjustments over the long term. These "regime" adjustments are most likely to occur as a small and gradual tendency towards channel widening in Segment 4, which is most affected by any change in the flow regime below the lake outlet. However, further study to confirm both the predicted changes in the flow regime and the resultant channel adjustments would appear to be warranted.

\subsubsection{Information Sources and Data Gaps}

Virtually all of the available information and data related to channel morphology, hydraulics and ice processes in the Lesser Slave River pertains to the river reach immediately below Lesser Slave Lake (Segments 4 and 5), and much of this deals specifically with the with assessing and monitoring the effects of the construction of the channel cutoffs and flow control weir. No information pertaining specifically to the lower reaches (Segments 1,2 and 3) is currently available.

The following information specific to Segment 4 and 5 is available:

- Stage discharge curve for hydrometric Station 07BK006 at Highway 2A (non active since 1988), located approximately $70 \mathrm{~m}$ upstream of the Tollenger Road Bridge in 
Segment 4 (Source: Environment Canada). Note that this station is located close to the boundary between Segments 3 and 4 (i.e., this station recorded outflow from Segment 4 and inflow to Segment 3). (Source: Environment Canada).

- Sediment data for hydrometric Station 07BK006 at Highway 2A (Tollenger Road) (Source: Environment Canada).

- Stage discharge curve for hydrometric Station 07BK001 (active since 1989) located at the lake outlet control weir, which forms the boundary between Segments 4 and 5 (Source: Environment Canada). This station records outflow from Segment 5 and inflow to Segment 4.

- Sediment data for hydrometric Station 07BK001 below Lesser Slave Lake (Source: Environment Canada).

- Technical assessments of the impact of channelization (cutoffs) and flow regulation (Source: Northwest Hydraulic Consultants Ltd. prepared for Alberta Environment).

- Engineering and planning studies on the impact of channelization and flow regulation (Source: Alberta Environment).

- Channel cross sections surveyed in connection with the Lesser Slave Lake Regulation Project (Source: Alberta Environment).

\subsubsection{Summary}

Based on the review of available information related to channel morphology and ice processes in the Lesser Slave River, the following data gaps are identified:

- There is virtually no specific morphological information available for Segments 1,2 and 3 .

- There is limited information in any of the segments on ice formation processes and essentially no data on mid-winter flows under ice cover and their impact on channel morphology, if any.

However, it is our opinion that these data gaps do not present any significant concern with respect to developing an IFN for the Lesser Slave River. Of more interest is the potential for morphological adjustments to the channel to occur in Segment 4 in response to the altered flow 
regime caused by flow regulation and the slope changes introduced by the channel cutoffs. It is expected that these adjustments will be both small and gradual.

\subsection{Water Quality}

\subsubsection{Overview}

The Lesser Slave River is part of the Athabasca River watershed, and also receives water from three sizable tributaries (i.e., the Otauwau, Saulteaux and Driftwood rivers). The river is divided into five segments, with water quality samples taken at a number of different locations within each segment (Figure 8).

Water quality in the Lesser Slave River normally reflects the quality in the outflow from Lesser Slave Lake, which is currently controlled by a downstream weir. The weir is upstream of the Town of Slave Lake which discharges treated municipal effluent to the river (Figure 8). The Lesser Slave River also receives agricultural runoff and effluent from Slave Lake Pulp Corporation (Slave Lake Pulp). In the winter, the Lesser Slave River is characterized by low flows and continuous ice cover, which persists for three to four months. Under these conditions, dilution capacity of the river is at the annual minimum and re-oxygenation is limited, suggesting the potential for effects on water quality.

Water quality in the Lesser Slave River has been monitored since the 1960s. AENV maintains six long-term monitoring stations along the river, and has stored data in the Water Data System (WDS) (AENV 2000). Continuous daily monitoring data collected by AENV were not available for this report, but a report summarizing recent monitoring data (AENV 2000) was reviewed. AENV (2000) identified water quality variables in the Lesser Slave River that were above water quality guidelines during periods of low flow as a result of effluent discharges.

Baseline and operational monitoring by Slave Lake Pulp during the past decade included studies by EVS (1990, 1991, 1992a, 1992b, 1995a, 1995b, 1996a). The 1990 and 1991 studies characterized baseline conditions, whereas subsequent studies investigated the effects of the pulp mill discharge. Winter water quality surveys were conducted by Slave Lake Pulp in the early to 


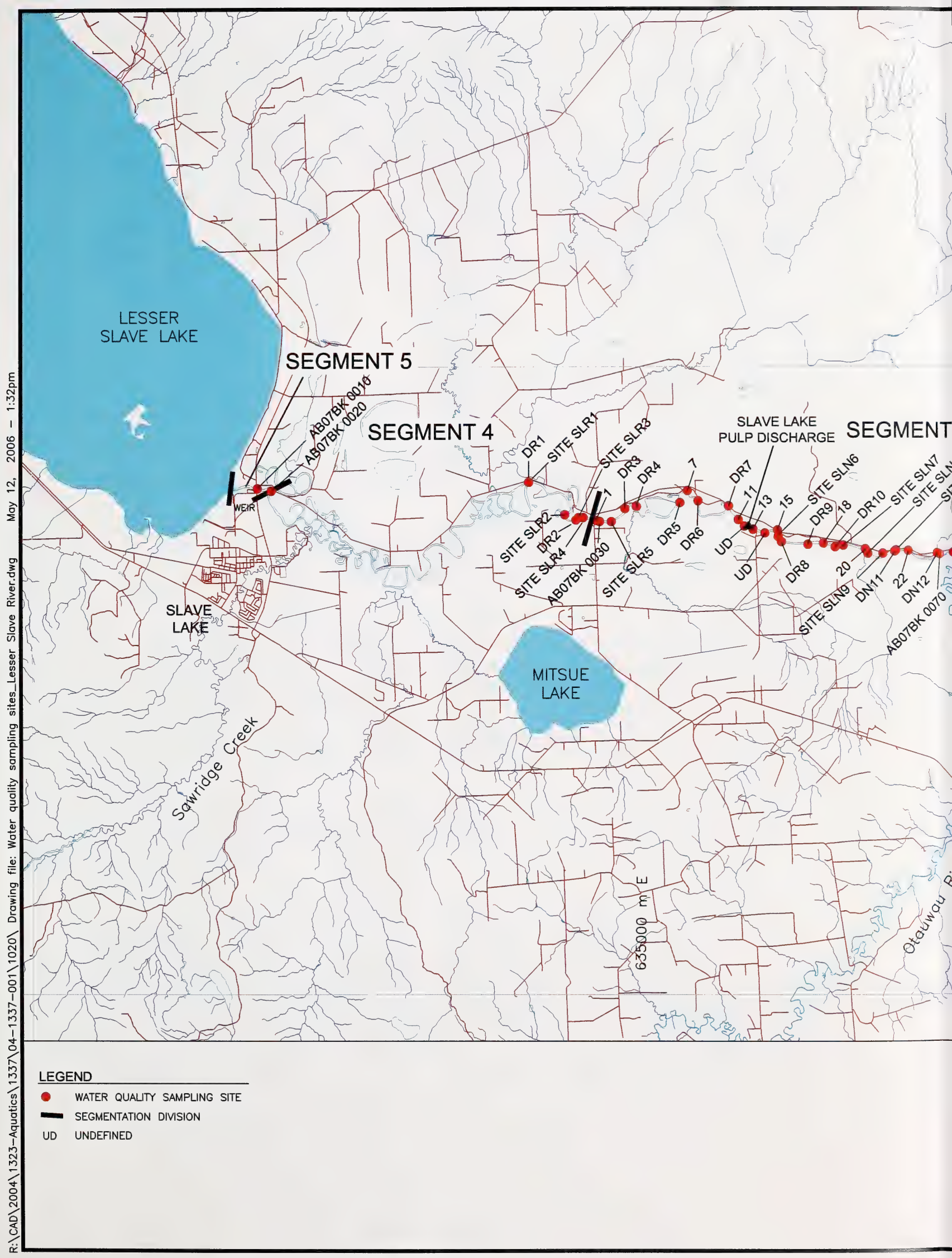


mid-1990s (EVS 1992c, 1993, 1994, 1995c). These surveys focused on dissolved oxygen (DO) and parameters associated with the pulp mill discharge. Monitoring was also conducted to meet the requirements of the federal Environmental Effects Monitoring (EEM) program (Environment Canada 1998). EEM surveys were carried out in 1995, 1998 and 2002 (EVS 1996b, Stantec and Golder 1999a, 1999b). Results of the most recent EEM cycle are not available at this time.

\subsubsection{Data Analysis}

Results of previous water quality surveys were used to characterize water quality throughout Segments 1 to 5 in the Lesser Slave River. A variety of parameters have been measured in each segment; however, this study focuses on parameters that have the potential to be influenced by changes in flow (based on an analysis by Golder [2003]), including:

- field parameters (conductivity, DO, water temperature);

- conventional parameters (total dissolved solids [TDS], total suspended solids [TSS], hardness, alkalinity);

- nutrients and carbon parameters (total phosphorus [TP], ammonia, total Kjeldahl nitrogen [TKN], total organic carbon [TOC], dissolved organic carbon [DOC]);

- selected metals (total metals - aluminum, chromium, iron, manganese and zinc); and,

- biological parameters (biochemical oxygen demand [BOD] and chlorophyll $a$ ).

Information collected after 1980 was summarized for each river segment by season (winter = November through March, spring = April and May, summer = June through August, and fall = September and October).

Historical data were compared to guidelines for the protection of freshwater aquatic life (AENV 1999; CCME 1999; U.S.EPA 1999a, 1999b). Water quality guidelines used in this assessment are presented in Table 7. Although total nitrogen (TN) data were not summarized, TKN concentrations were compared against the TN guideline because most of TN is contributed by TKN in the Lesser Slave River. Nitrate and nitrite were usually low (nitrate: $<0.003$ to $0.2 \mathrm{mg} / \mathrm{L}$; nitrite: $<0.001$ to $0.022 \mathrm{mg} / \mathrm{L}$ ). 
Table 7

Water Quality Guidelines for the Protection of Aquatic Life

\begin{tabular}{|c|c|c|c|c|c|}
\hline \multirow[b]{2}{*}{ Parameter } & \multirow[b]{2}{*}{ Units } & \multicolumn{2}{|c|}{ Aquatic Life Guidelines } & \multicolumn{2}{|c|}{ Guideline Source } \\
\hline & & Acute & Chronic & Acute & Chronic \\
\hline dissolved oxygen & $\mathrm{mg} / \mathrm{L}$ & $5^{(a)}$ & $6.5^{(\mathrm{b})}$ & AENV 1999 & AENV 1999 \\
\hline ammonia $^{(\mathrm{c})}$ & $\mathrm{mg} / \mathrm{L}$ & 5.6 & 2.43 & U.S. EPA & U.S. EPA \\
\hline total phosphorus & $\mathrm{mg} / \mathrm{L}$ & - & 0.05 & - & AENV 1999 \\
\hline total nitrogen & $\mathrm{mg} / \mathrm{L}$ & - & 1 & - & AENV 1999 \\
\hline aluminum & $\mathrm{mg} / \mathrm{L}$ & 0.75 & 0.1 & U.S. EPA & CCME 1999 \\
\hline chromium VI & $\mathrm{mg} / \mathrm{L}$ & 0.016 & 0.001 & U.S. EPA & CCME 1999 \\
\hline iron & $\mathrm{mg} / \mathrm{L}$ & - & 0.3 & - & CCME 1999 \\
\hline zinc & $\mathrm{mg} / \mathrm{L}$ & $0.193^{(\mathrm{d})}$ & 0.03 & U.S. EPA & CCME 1999 \\
\hline
\end{tabular}

(a) 1-day minimum.

(b) 7-day mean.

(c) Guidelines are $\mathrm{pH}$ (acute and chronic) and temperature (chronic) dependent; values shown here correspond to a pH of 8 and water temperature of $10^{\circ} \mathrm{C}$, respectively; these guidelines were calculated based on site-specific conditions using the methods described in AENV (1999) and U.S. EPA (1999b). Guideline is hardness dependent; values shown here are based on a hardness of $175 \mathrm{mg} / \mathrm{L}$; the guideline was calculated based on site-specific hardness levels using the methods described in AENV (1999) and U.S.EPA (1999a).

- = no guideline.

The following sections present the results of the data analysis, discussion of seasonal and spatial trends, and recommendations for future investigations. The water quality data presented in tables within this section are based mainly on WDS summary data as entering raw data from other sources was beyond the current scope.

\section{Segment 1}

Segment 1 is one of the most frequently sampled reaches of the Lesser Slave River, with 154 water quality samples collected since 1980. River water in this segment tends to be well oxygenated (i.e., median values of 8 to $12 \mathrm{mg} / \mathrm{L}$ ). Although seasonal variation appears to be minimal, median values have been slightly higher under ice, likely due to increased solubility of oxygen in colder water (Table 8). Despite the generally high median concentrations, continuous daily monitoring data collected by AENV showed that DO did not meet the chronic $(6.5 \mathrm{mg} / \mathrm{L})$ or acute $(5 \mathrm{mg} / \mathrm{L})$ guidelines for the protection of aquatic life in early December 1999 (AENV 2000). Flow over the outlet weir virtually ceased during this period, likely causing the drop in DO concentration. Licensed temporary diversions restored flow shortly after, and DO concentrations returned to acceptable levels. These monitoring data indicate that reducing flows to very low levels can have direct effects on water quality in the river. 


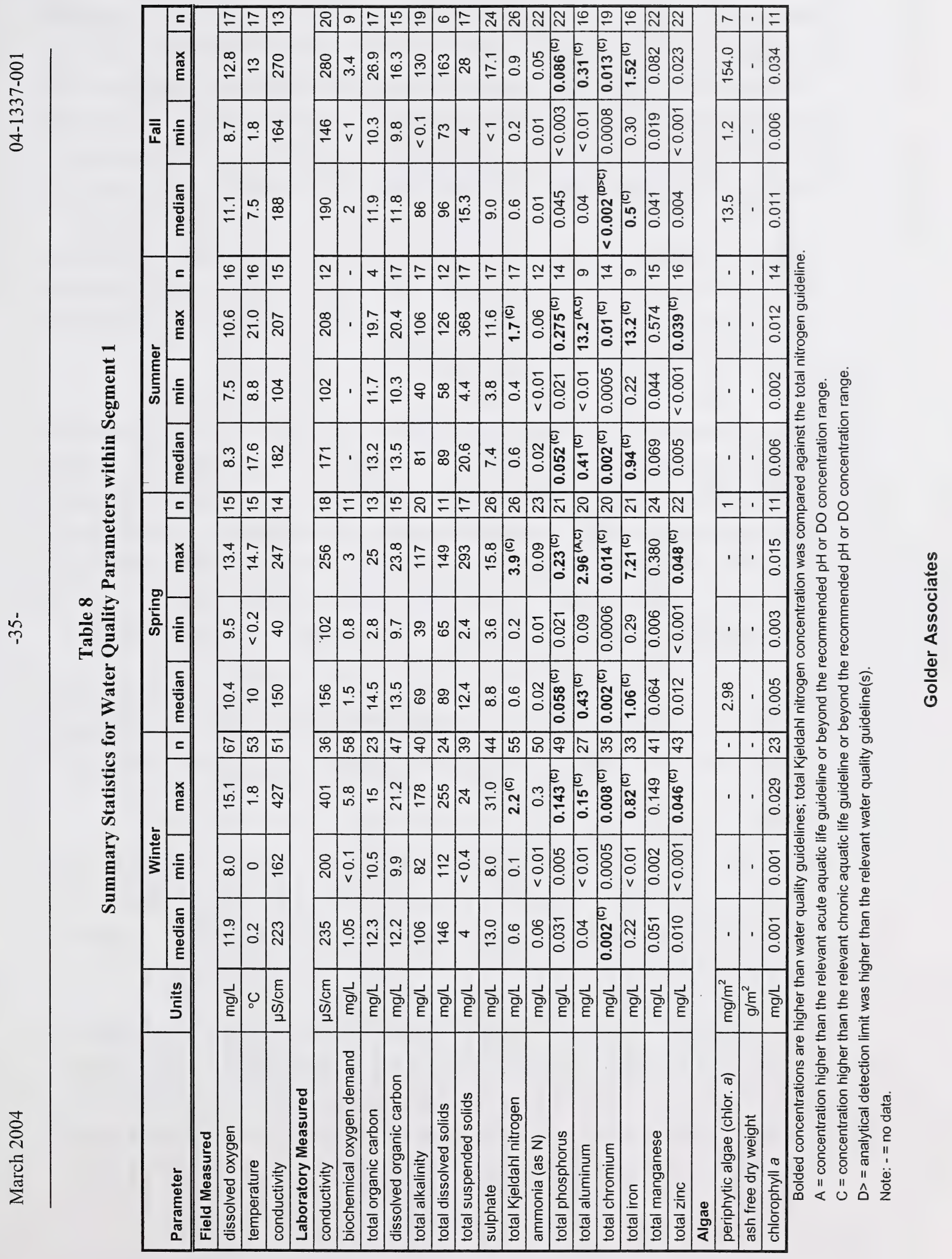


Water temperature was generally within recommended criteria for mountain whitefish, the most temperature sensitive species in this system (Taylor and Barton 1992). However, the fall median value of $7.5^{\circ} \mathrm{C}$ was above the spawning and incubation requirement (i.e., seven days with a daily maximum of $6^{\circ} \mathrm{C}$ ), suggesting that the fall median corresponds to the period before spawning.

Water in this segment was slightly alkaline, with maximum alkalinity in the winter (Table 8). Maximum conductivity and TDS levels were also observed in the winter, and declined during the spring and summer. DOC and TOC concentrations were usually low and did not vary seasonally, whereas TSS level was highest in the spring and summer.

Median TP concentration was highest in the spring, with a median value $(0.058 \mathrm{mg} / \mathrm{L})$, almost twice the median observed in winter $(0.031 \mathrm{mg} / \mathrm{L})$ (Table 8$)$. Maximum TP concentrations were above the chronic guideline for the protection of aquatic life $(0.05 \mathrm{mg} / \mathrm{L})$ in all seasons, and median values were slightly above the guideline in spring and summer. TKN concentrations were generally low and median values did not vary by season, but maximum TKN concentrations were above the chronic guideline for total nitrogen in most seasons. Median chlorophyll $a$ level was lowest in the winter and gradually increased throughout the year, with the maximum concentration in the fall.

Most of the metals varied seasonally, with higher concentrations during the open-water period, when TSS concentrations tend to be higher (Table 8). Total aluminum, chromium, iron and zinc have been higher than the relevant chronic aquatic life guideline on one or more occasions.

\section{Segment 2}

The majority of the 36 water quality samples collected from Segment 2 were obtained during the winter. Few samples were collected in the spring and summer, and there were generally only three or four values for each parameter in the fall. Thus, evaluation of seasonal variability is limited to fall and winter.

Similar to Segment 1, river water in Segment 2 is usually well-oxygenated (i.e., median values of 9 to $12 \mathrm{mg} / \mathrm{L}$ ), with maximum levels in the winter (Table 9). Temperatures were generally within recommended criteria for mountain whitefish, although the fall median value of $10^{\circ} \mathrm{C}$ was above the spawning and incubation requirement. Conductivity, TDS and alkalinity levels were generally higher in the winter, and DOC and TOC were usually low with little variability among seasons. 


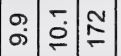

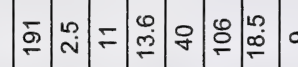

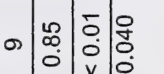

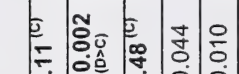

$--$.

\section{.}

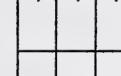

$$
\begin{array}{llllllll}
\hline & . & . & . & . & . & . \\
\hline
\end{array}
$$

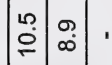
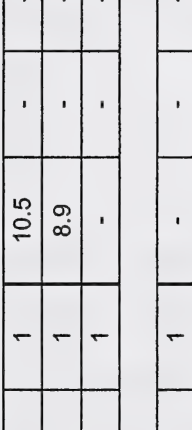

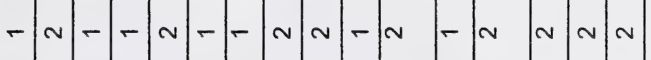

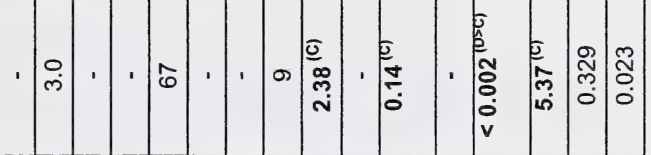

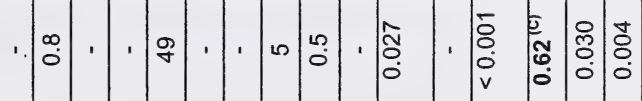

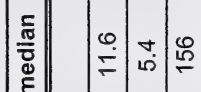

\section{$\infty$}

ลิก

$2 \pi$

Z $8 \sum_{0}$

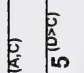

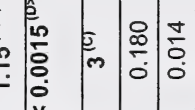

\begin{tabular}{|l|l|l|}
\hline A & 2 & 7 \\
\hline
\end{tabular}

n.

a 1 r

官 $\stackrel{\circ}{\rightarrow}$

กิ่

$2 \underset{\frac{0}{2}}{2}$

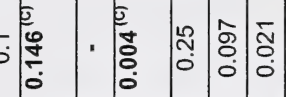

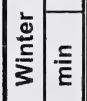

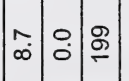

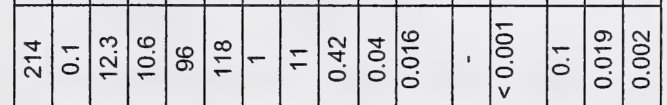

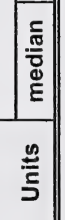

ปิ

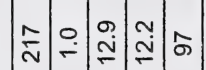

ลิ

$\simeq$

$\sqrt[0]{\frac{0}{0}}$

\% 웅

- 19

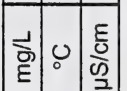

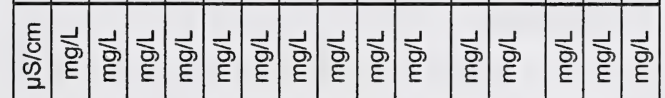

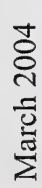

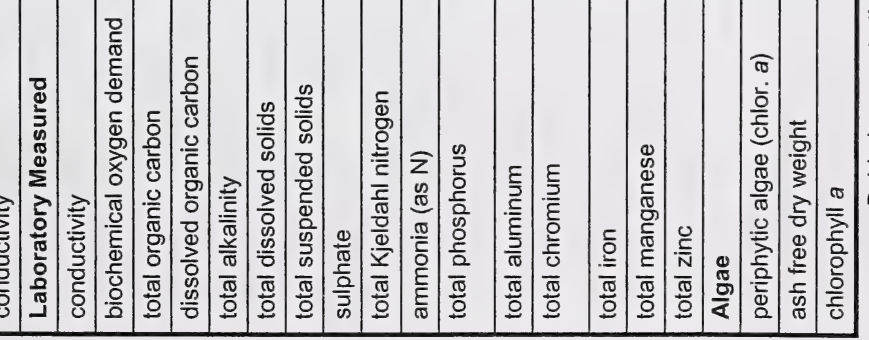

.

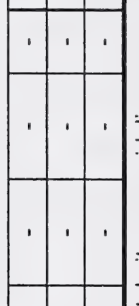

बू

䨌 品 은 뜬 䨌 屯. ठ है: 宂 省 을 응 䨔

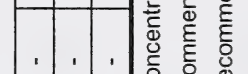
吕 ) 을 흥 กิ

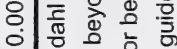

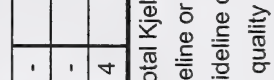
은 응

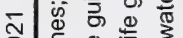
ठิ

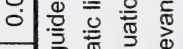
$\checkmark$ 잉 훙 8 đ 0 ○)

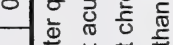

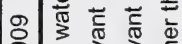
通

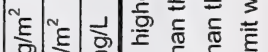

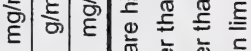
๙ิ 흐

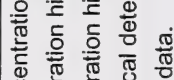


Median TP and TKN concentrations were highest in the spring, and chlorophyll $a$ concentrations were highest in fall (Table 9). Spring medians and maximum seasonal concentrations of TP and TKN concentrations were above the chronic aquatic life guidelines. Median concentrations of total aluminum, iron, zinc and manganese were highest in the spring, reflecting increased flow typical of this season. Total chromium and iron concentrations were above the relevant chronic aquatic life guidelines, and aluminum level was also above acute guideline.

\section{Segment 3}

Although Segment 3 is the most intensively sampled segment, with 174 samples collected since 1980 , very few samples were collected during the summer. Similar to the downstream segments, DO concentration in Segment 3 was near saturation (i.e., median values ranging from 10.5 to $12.6 \mathrm{mg} / \mathrm{L}$ ), and winter concentrations were slightly higher than in other seasons (Table 10). Temperature was generally within criteria recommended for mountain whitefish, although the fall median value of $10.7^{\circ} \mathrm{C}$ was above the spawning and incubation requirement. TDS, alkalinity and conductivity were highest in the winter, while DOC and TOC concentrations did not appear to vary seasonally.

Median TP concentrations were similar in spring and fall (about $0.04 \mathrm{mg} / \mathrm{L}$ ) and higher than those observed in the winter $(0.018 \mathrm{mg} / \mathrm{L})$. TP was above the chronic aquatic life guideline in the spring (Table 10), and maximum TP and TKN concentrations were above chronic guidelines in all seasons. Median TKN concentration did not appear to vary seasonally. Both TP and TKN reflected nutrient inputs from Slave Lake Pulp. Available benthic algal and chlorophyll $a$ data indicate that productivity was highest in the fall.

Similar to other segments, total aluminum, iron, manganese and zinc concentrations were highest in the spring. Elevated metals concentrations in Segment 3 do not appear to be strongly correlated with high TSS concentrations, since peak TSS concentrations occurred in the fall. With the exception of manganese (there is no aquatic life guideline for this parameter), total metal concentrations were above the relevant chronic guidelines on one or more occasions in Segment 3 (Table 10). 


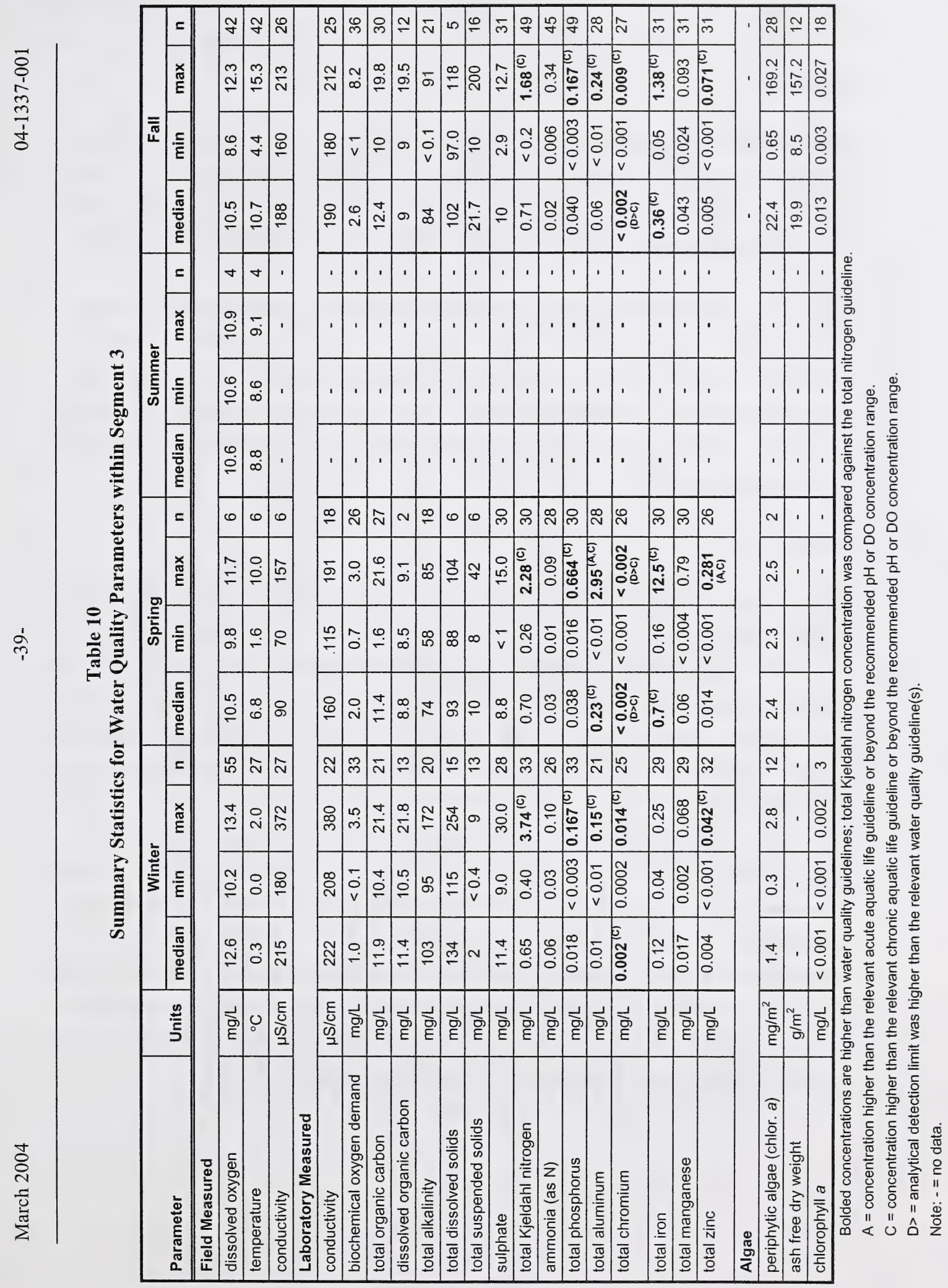




\section{Segment 4}

Only ten water quality samples have been collected in Segment 4, during the winter and fall. DO concentration was high in both winter and fall, with medians of $13 \mathrm{mg} / \mathrm{L}$ and $11.5 \mathrm{mg} / \mathrm{L}$, respectively (Table 11). Field conductivity measurements were slightly higher in winter than in fall, and water temperatures were generally within recommended criteria for mountain whitefish.

Median TP concentration was higher in fall than in winter, and the maximum value was higher than the chronic guideline of $0.05 \mathrm{mg} / \mathrm{L}$ in the fall. In contrast, the median TKN concentration in winter was $0.58 \mathrm{mg} / \mathrm{L}$ while concentrations in fall were below detection limits. The periphyton samples collected in fall indicate that, as expected, there is a higher algal biomass in the fall than in the winter. Total aluminum, manganese, zinc and iron were only measured in the winter, and concentrations were low.

\section{Segment 5}

Data for Segment 5 are available from one site just upstream of the weir. There have been 69 samples collected at this station since 1980. Most of the samples were collected in the winter, but each of the other seasons is represented by at least 10 samples (Table 12). Median DO concentrations ranged from 9 to $13 \mathrm{mg} / \mathrm{L}$, and winter concentrations were slightly higher than those in other seasons. Median conductivity, TDS and alkalinity levels were slightly higher in winter, but variability among seasons was low. Temperature was generally within recommended criteria for mountain whitefish.

Median TKN concentration was similar among seasons, but TP concentration generally increased from winter to fall. Maximum TKN concentration in the winter was above the chronic aquatic life guideline. The maximum TP concentration was observed in the summer, when it was higher than the chronic aquatic life guideline. Periphytic algae also had the greatest biomass in the fall. Total metal concentrations appeared to vary slightly by season, since median concentrations were higher in summer than in other seasons. However, total aluminum, chromium and iron concentrations were above chronic aquatic life guidelines in most seasons. 
o
$\frac{1}{m}$
$\frac{7}{\dot{0}}$

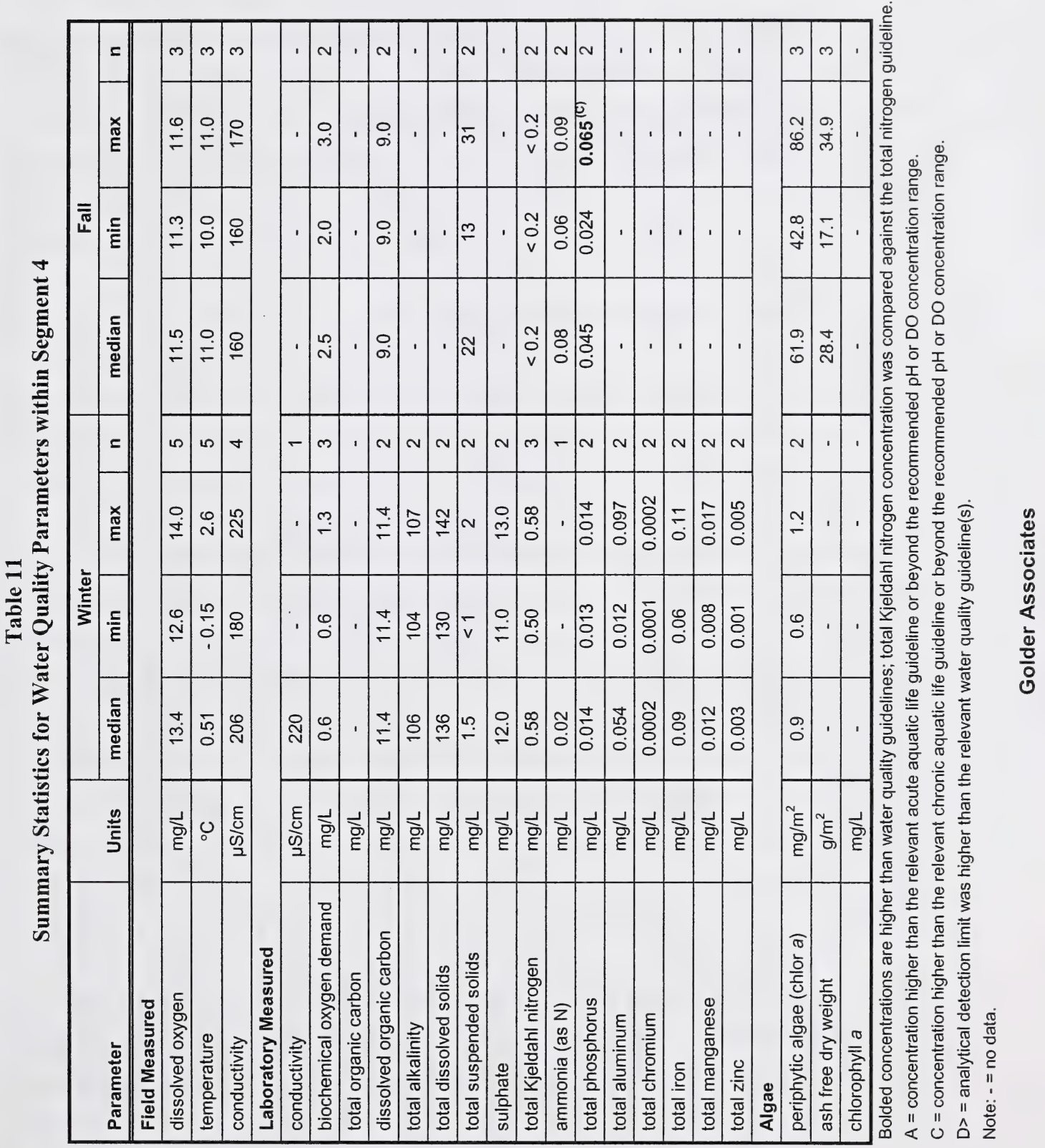

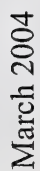




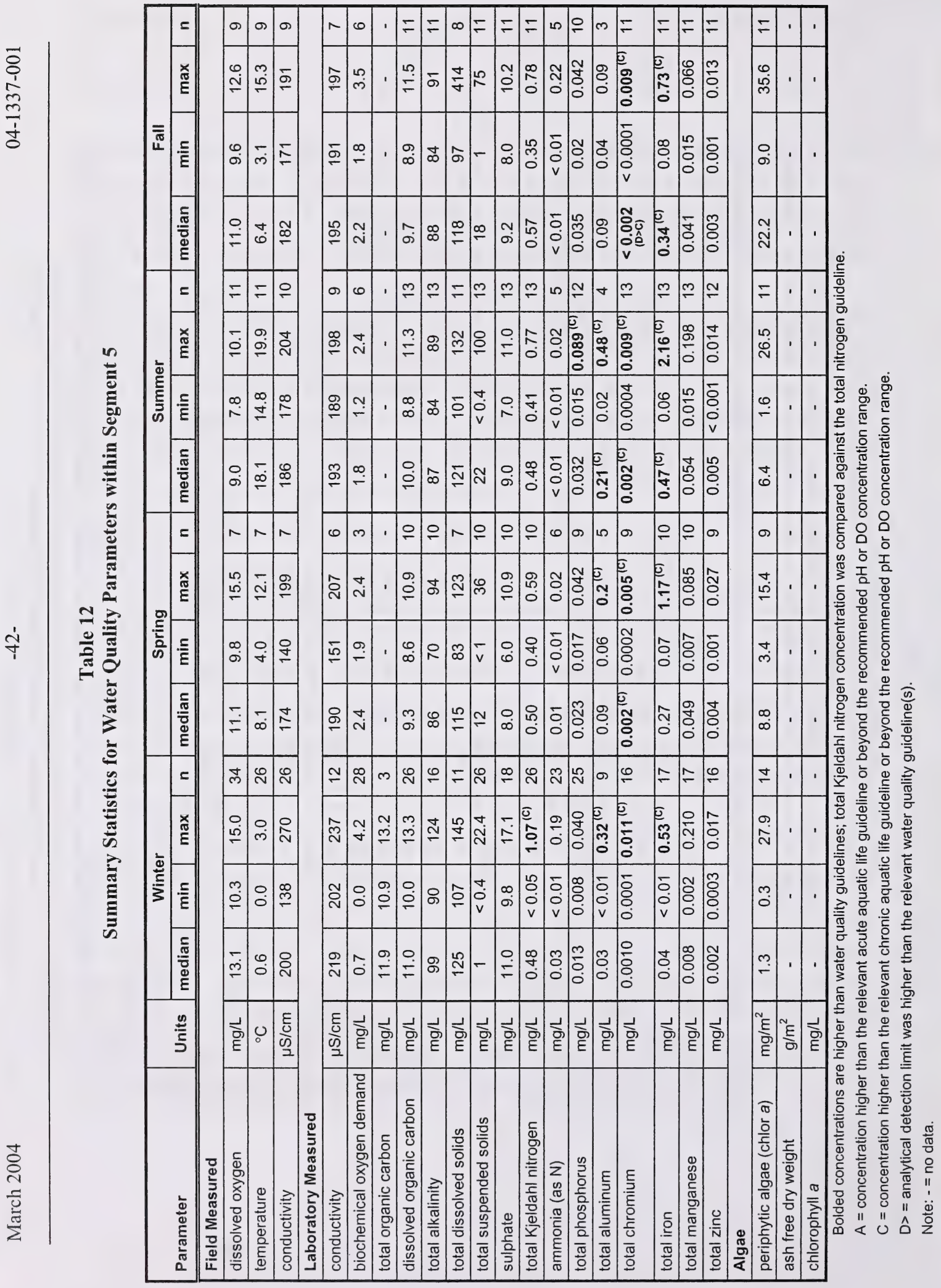




\subsubsection{Spatial Trends}

Water quality in the Lesser Slave River is normally determined in large part by the quality of the outflow from Lesser Slave Lake (AENV 2000). The influences of tributaries, municipal discharge and pulp mill effluent on water quality can be greater during low flow conditions. The Town of Slave Lake municipal discharge enters the Lesser Slave River in Segment 4 and the Slave Lake Pulp effluent diffuser is in Segment 3 (Figure 8). Segment 5 is located upstream of the weir and is unaffected by effluent discharges.

DO concentration does not appear to vary along the length of the Lesser Slave River (Figure 9). DO in Segment 1 (i.e., the farthest downstream segment) was continuously monitored by AENV during the cessation of flows in the winter of 1999 (AENV 2000). Results indicate that reducing flows at the weir can affect water quality in all segments of the river in a relatively short timeframe. DO concentrations in Segment 1 recovered shortly after flow was restored.

Maximum winter TDS and DOC concentrations were observed in the downstream segments (i.e., segments 1, 2 and 3) (Figures 10 and 11). TSS exhibited a very slight increasing trend with distance downstream in the winter, but remained low during this season (Figure 12). No spatial trends were apparent in other seasons. Seasonal median TSS was higher in the spring than in winter, and was highest in summer and fall. Nutrient concentrations were higher at the downstream segments than near the lake outflow. Figures 13 and 14 illustrate that maximum TKN and TP concentrations increased substantially in Segment 3 and remained elevated in the rest of the river. Nutrient and DOC increases appear to be predominantly caused by the discharge of pulp mill effluent, since concentration spikes are not observed until Segment 3. There is no apparent effect of the municipal discharge on water quality in Segment 4.

There was a gradual downstream increase in total iron during the winter (Figure 15). Metal parameters are often associated with suspended solids and the observed increases may have been due to tributary inputs, but were also consistent with the shallow trend observed in TSS in the winter. 

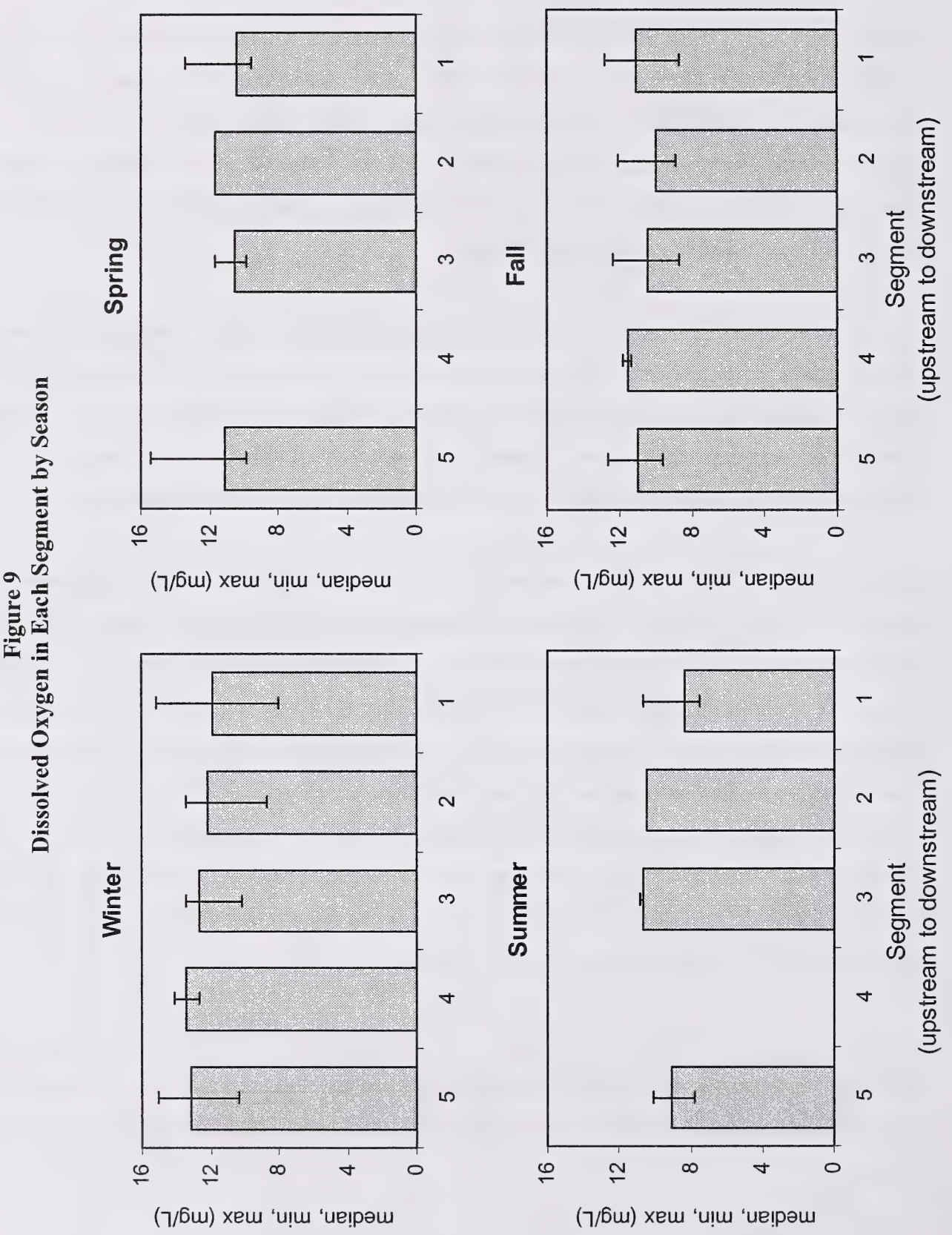


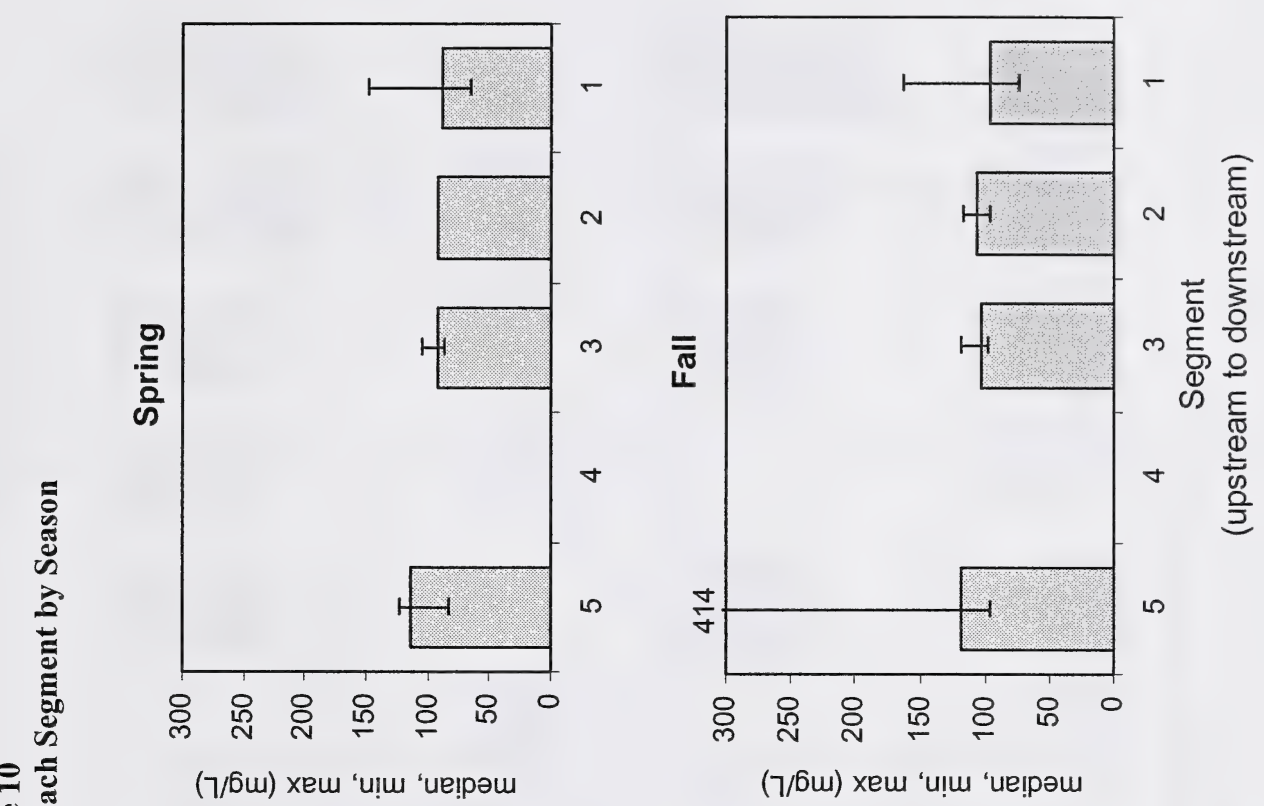

(7/Бw) хеш 'и!̣ 'uе!̣рәш
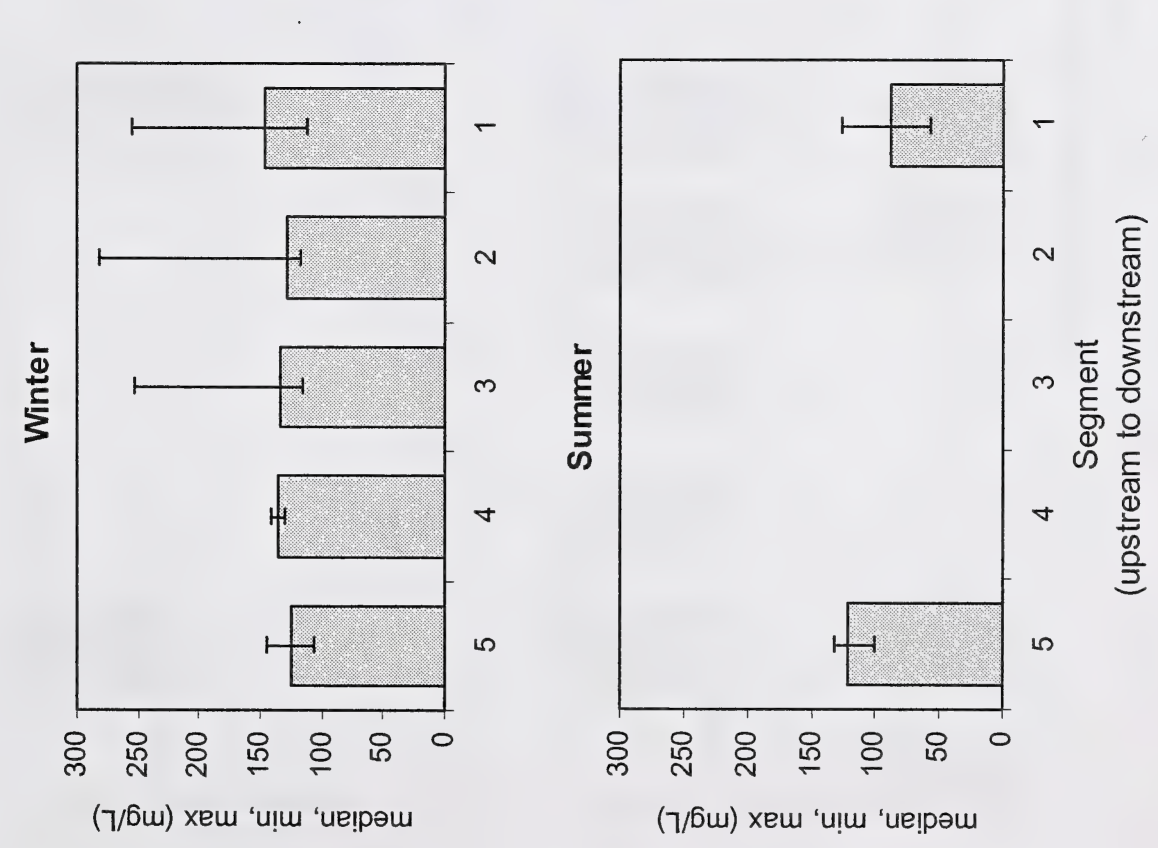

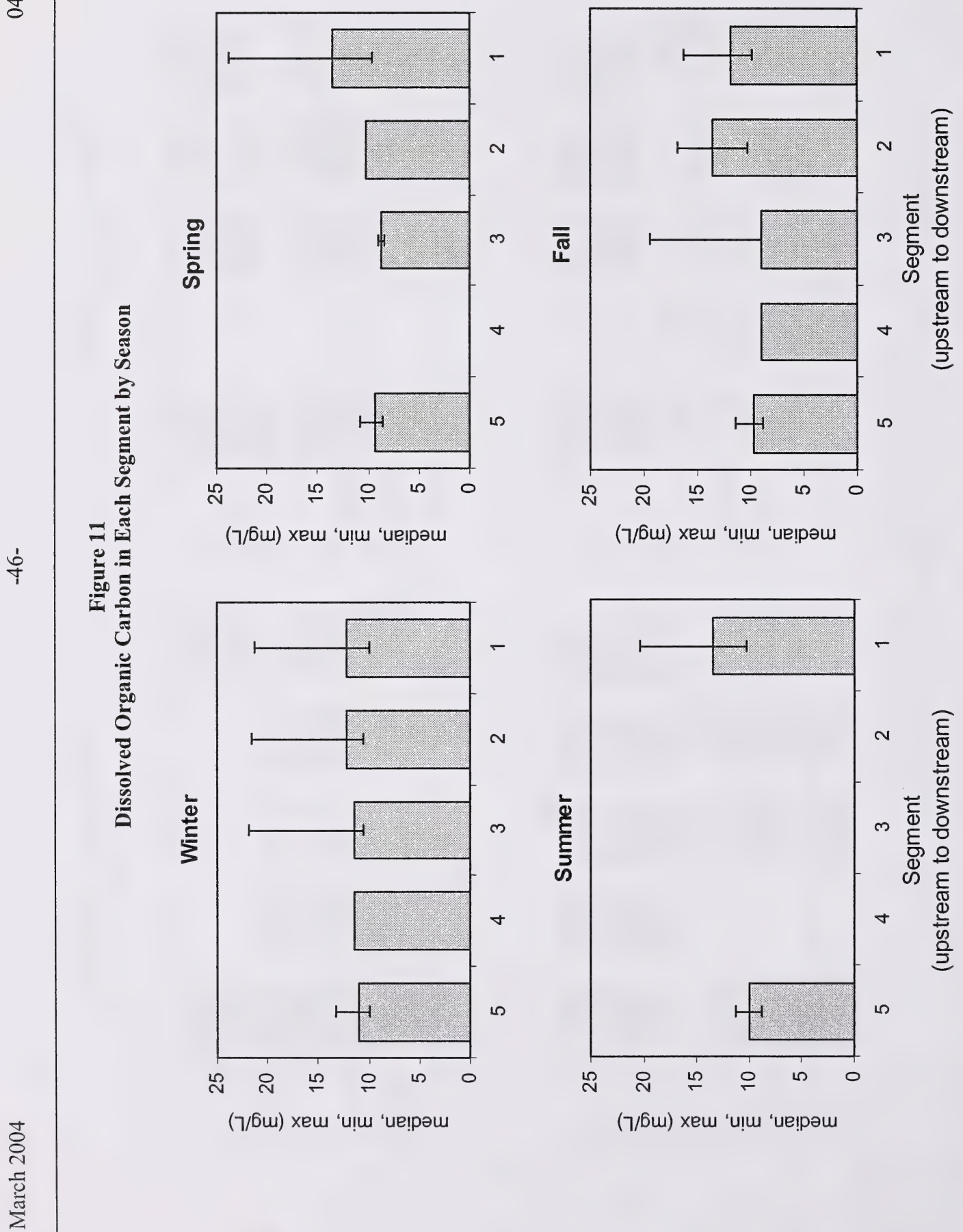
$\frac{5}{8}$
$\frac{1}{m}$
$\frac{7}{0}$

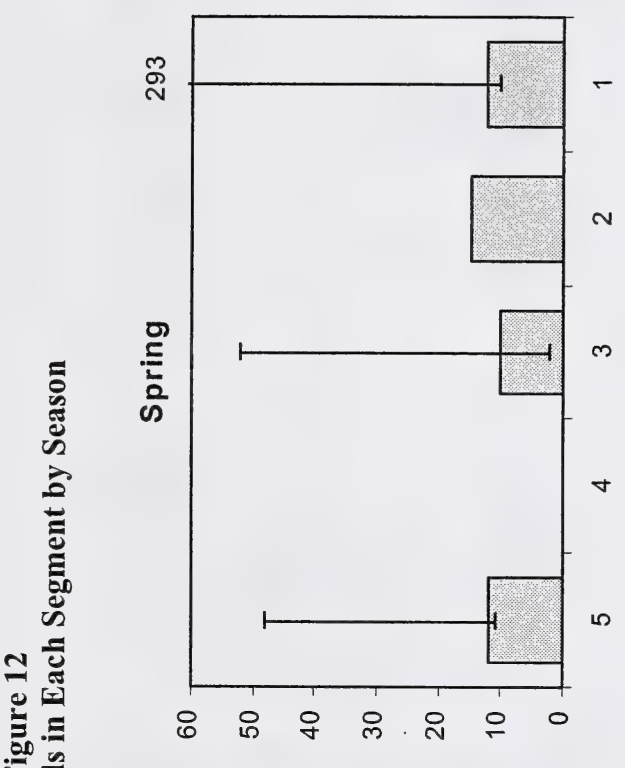

( $7 / 6 m)$ хеш 'u!̣ 'ие!̣рәш

广

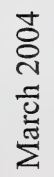

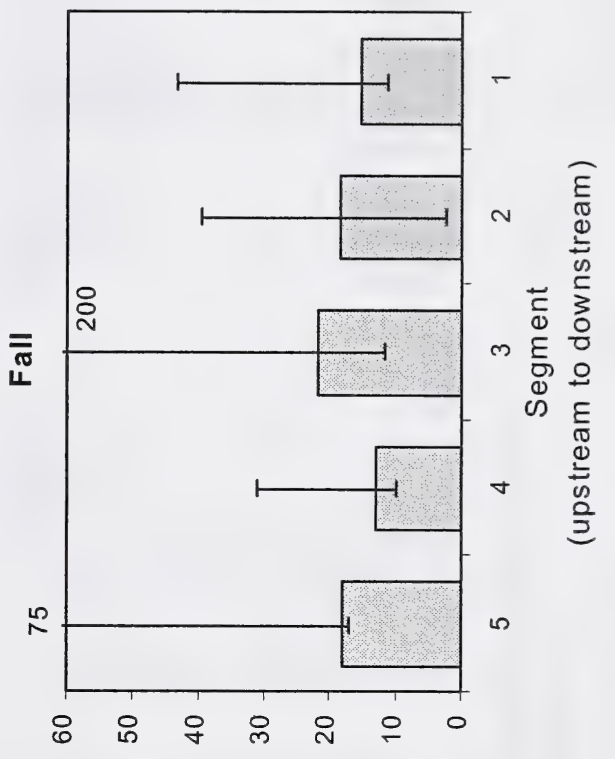

( $7 / 6 w)$ xem 'u!̣ 'ие!̣рәш

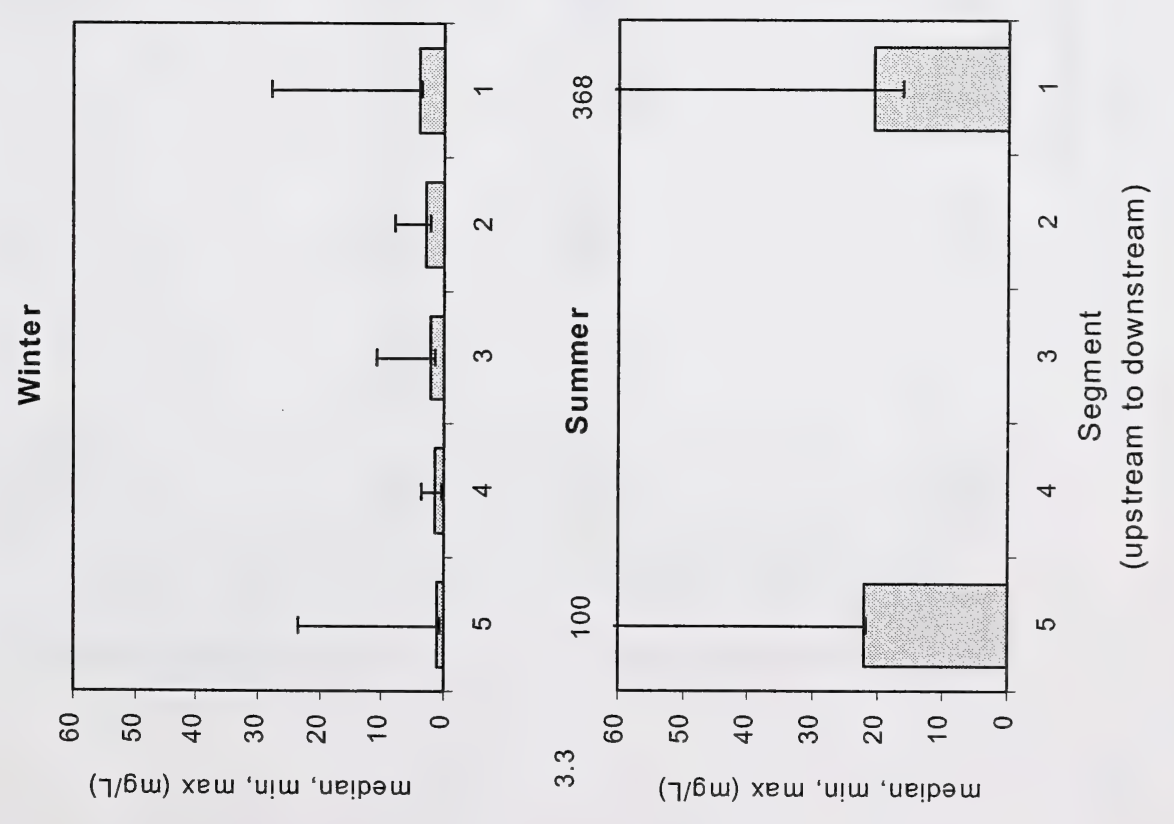



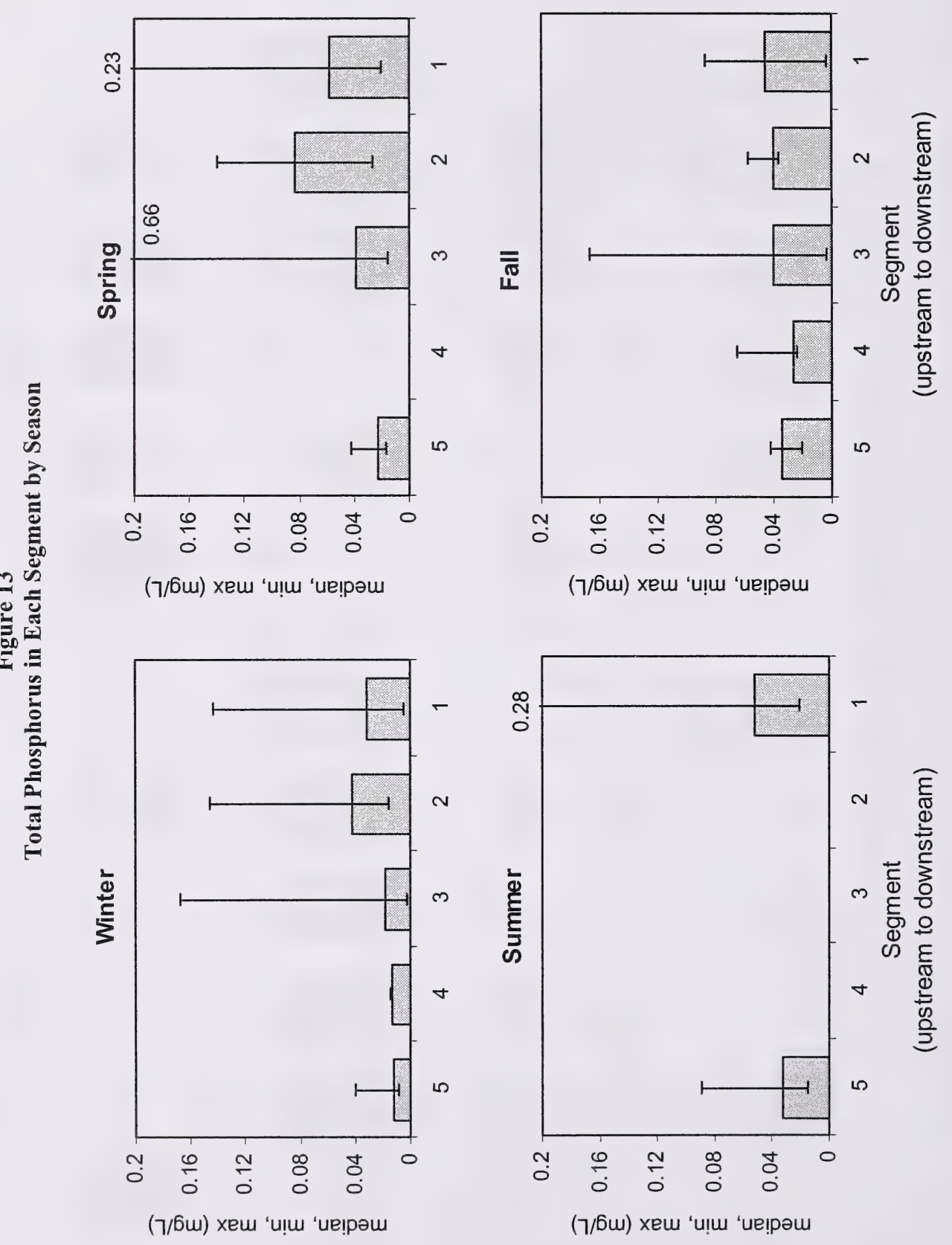


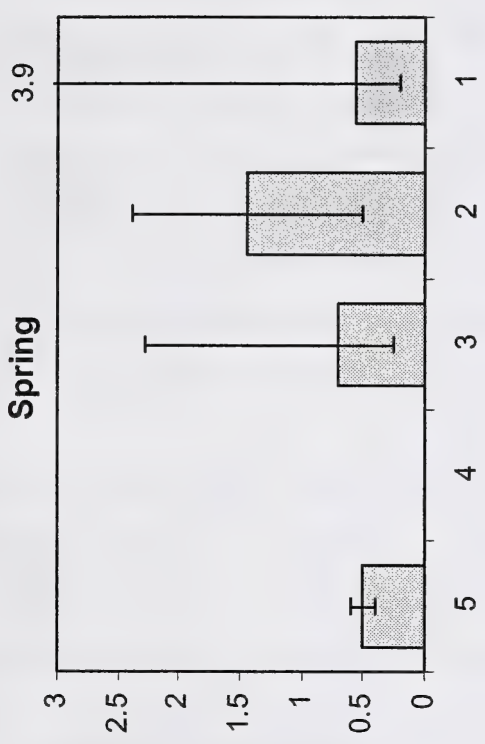

(7/6w) xew ‘u!̣ 'ue!pəw

ণ่

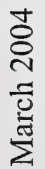

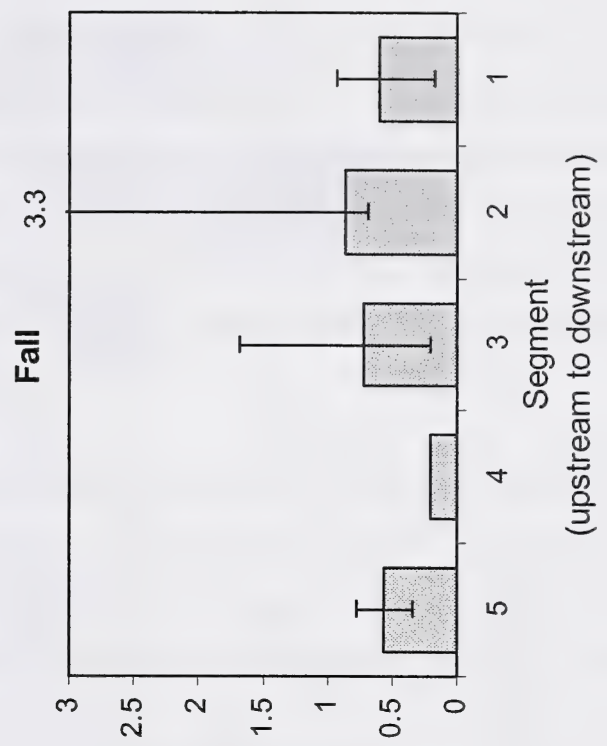

(7/6w) xеш ‘u!ш 'ие!̣рәш

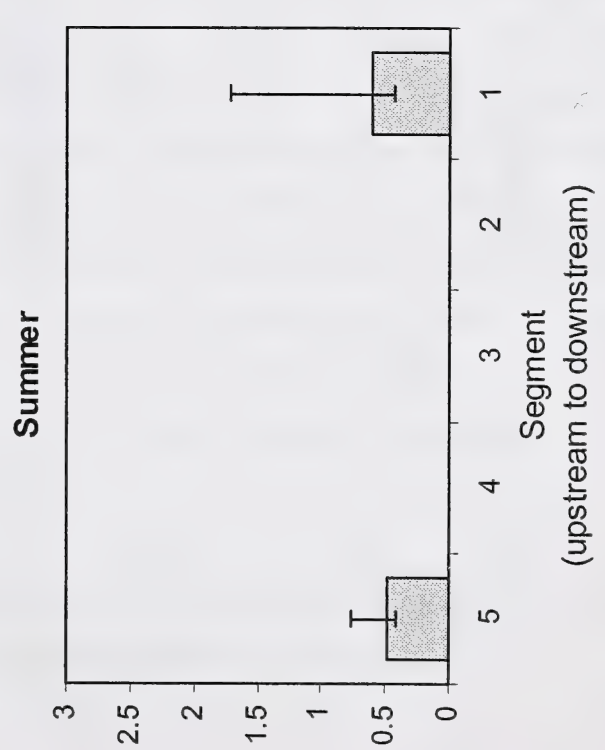

(7/6ш) хеш 'и!̣ 'ие!рәш 


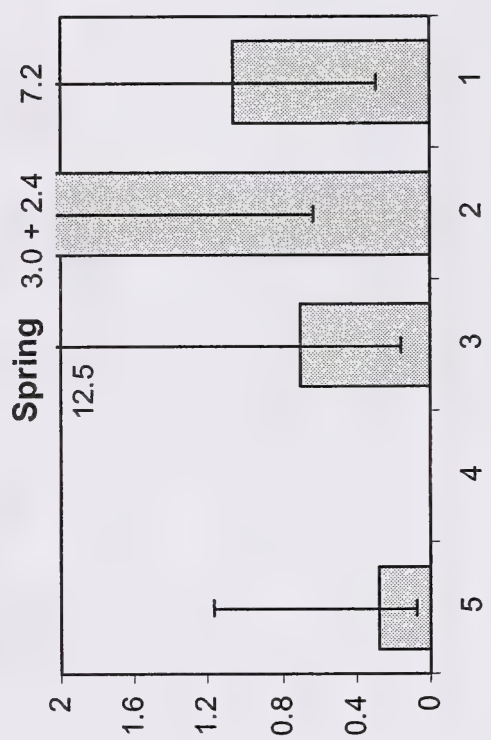

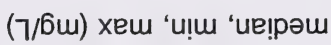

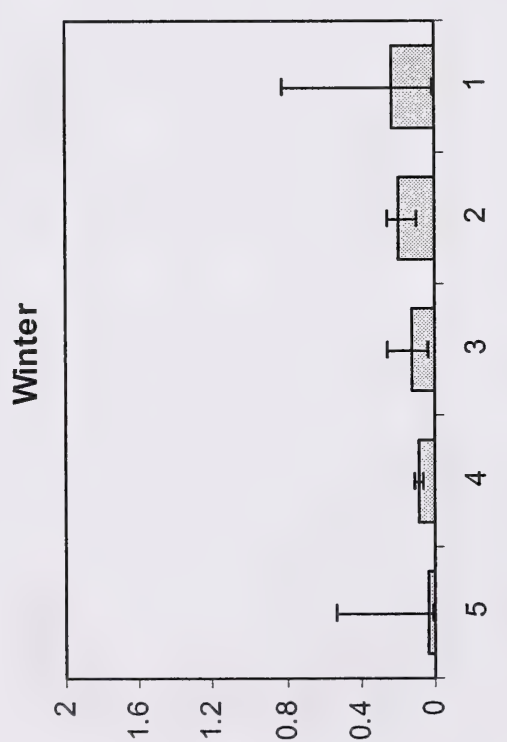

(7/бш) хеш 'и!ш 'ие!рәш

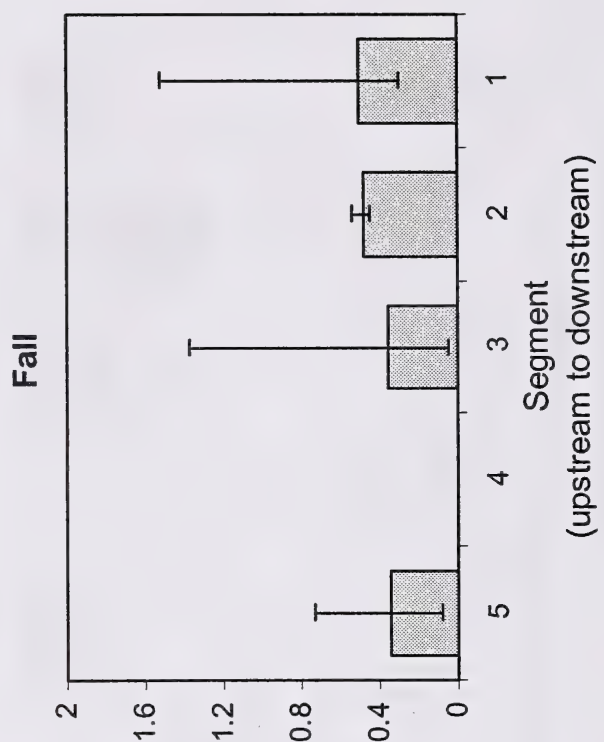

(7/бw) xеш 'u!̣ 'ие!рәш

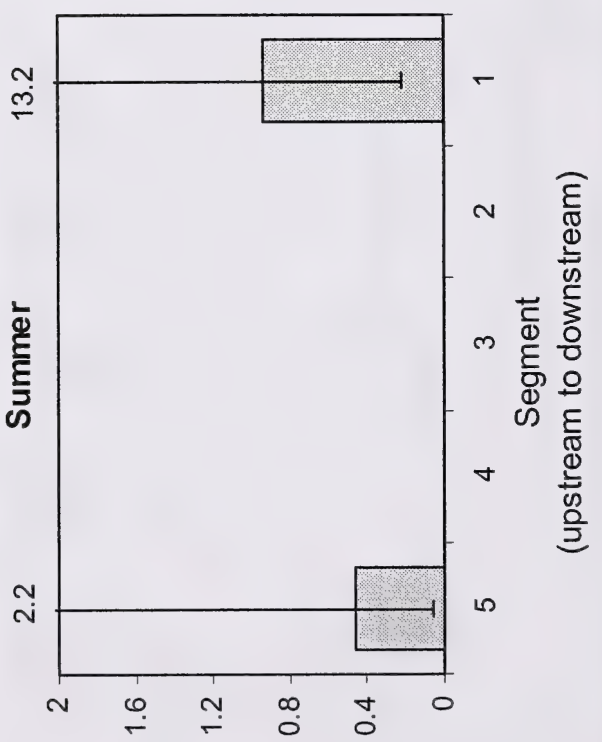

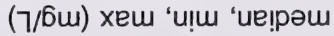




\subsubsection{Summary}

The Lesser Slave River waters tend to be well oxygenated, despite a discharge of nutrients from the Town of Slave Lake and Slave Lake Pulp. This may be in part due to an increase in gradient in the downstream river segments, which can result in re-oxygenation by a relatively short distance downstream of effluent inputs. DO concentration has dropped below acceptable levels at least once, when flow in the river was almost negligible (AENV 2000). Levels were observed to recover as the flow increased to more typical conditions. The threshold flow condition corresponding to acceptable DO levels is not known.

Seasonal variation was evident for DO, TSS, nutrients and some metals (Tables 7-11). DO was slightly higher in the winter, likely due to the increased solubility of oxygen in colder water. Variation in nutrients and some metals likely reflects seasonal changes in suspended sediments and increased flows during the open-water season. Algal biomass is generally highest in the fall and declines in winter, possibly reflecting low light levels and ice scour.

Concentrations of nutrients and some metals were above aquatic life guidelines in most segments, but tended to be higher in the downstream segments than near the outflow from the Lesser Slave Lake. Sources of nutrients include the Town of Slave Lake, Slave Lake Pulp, and agricultural activities in the watershed. Figures 13 and 14 illustrate that the pulp mill is likely the most important source of nutrients in the Lesser Slave River. AENV (2000) stated that DO, colour, cadmium, zinc, phosphorus and nitrogen concentrations in the Lesser Slave River were affected by effluent discharges and, as a result, exceeded water quality guidelines during the low flow surveys in winter 1999-2000. AENV (2000) concluded that greater effects on water quality than is typical have occurred during this period because low flows provided minimal dilution of effluents.

As noted for DO, flow reductions in the Lesser Slave River can have direct effects on water quality. Potential issues related to further flow reductions include the following:

- reduced assimilative capacity for existing and future discharges from Slave Lake Pulp and the Town of Slave Lake; 
- reduced assimilative capacity for agricultural runoff which likely accounts for a part of existing nutrient loads, and in turn increase the potential for macrophyte and algal growth; and,

- contribution of groundwater to river flows might increase, resulting in increased levels of dissolved ions.

\subsubsection{Recommendations}

\section{Data Gaps}

The examination of the Lesser Slave River water quality database revealed some gaps. There has been very little data collected from segments 2,3 and 4 , especially in summer. Data for Segment 4 is especially scant, making it difficult to determine seasonal variability.

\section{Future Work}

An exploration of the relationships between concentrations of water quality parameters and flow in the Lesser Slave River may aid in predicting effects of low flow conditions on water quality in the river. Therefore, additional work could involve the following tasks:

- Statistically determine which parameters are influenced by flow; and,

- Use this relationship, or a calibrated water quality model to predict changes to flow related parameters under various flow conditions.

This scoping study focused on parameters that are typically related to flow based on trends observed in other rivers. Linear regression and/or correlation analysis could be used to statistically determine which parameters are related to flow. The process would be similar to the analysis conducted for the Athabasca River as part of the Regional Aquatics Monitoring Program (RAMP) (Golder 2003). There is sufficient water quality and flow information to complete an initial assessment. This type of analysis would likely identify additional data needs.

A calibrated hydrodynamic/water quality model could also be used to predict changes in water quality related to changes in flow. AENV has recently developed a water quality model for the Lesser Slave River using CE-QUAL-W2. The hydrodynamic component of the model has been 
calibrated by AENV but no water quality calibrations have been completed. It is expected that this model could be used to evaluate flow-related changes in water quality in the Lesser Slave River with the available data and some additional effort.

\subsection{Benthic Invertebrates}

\subsubsection{Previous Surveys in the Lesser Slave River}

The Lesser Slave River has been straightened in its upstream reaches and its flow is currently controlled by a weir downstream of Lesser Slave Lake. The river receives municipal discharge from the Town of Slave Lake. Effluent from Slave Lake Pulp is released into the Lesser Slave River in Segment 3. Land in the area is utilized for agriculture. The Lesser Slave River is part of the Athabasca River drainage and receives water from three sizeable tributaries, the Otauwau, Saulteaux and Driftwood Rivers.

The Lesser Slave River has been sampled for benthic invertebrates by 12 studies from 1989 to the present. The objective of the first two studies was to present a quantitative baseline assessment of the benthic invertebrate community (EVS 1990, 1991). The data collected by these studies were used as a baseline for monitoring of operations at the Slave Lake Pulp Corporation's (Slave Lake Pulp) mill, which discharges wastewater into the river (EVS 1992a, 1992b, 1995a, 1995b, 1995c, 1996a, Stantec 2000). Two studies (EVS 1996b, Stantec and Golder 1999a, 1999b) were conducted as part of Slave Lake Pulp's Aquatic Environmental Effects Monitoring (EEM) program, as required by Environment Canada (Environment Canada 1998). Results of the most recent (2002) EEM study are not available at this time.

In total, 47 sites were sampled for benthic invertebrates by the above studies (Figure 16), with over half (30) in the intensively sampled reach in Segment 3, upstream and downstream of the Slave Lake Pulp effluent discharge. Spacing of sites along the river was variable and spatial coverage of the river outside of Segment 3 was considerably lower. Segment 1 located downstream of the Driftwood River had six sample sites. Segment 2, located between the Driftwood and Saulteaux rivers, also had six sample sites. Segment 4 , the farthest upstream reach, had five sites. Samples were not collected upstream of the flow control weir. Of the 47 sites in the Lesser Slave River, 20 were in depositional habitat and 27 were in erosional habitat. 


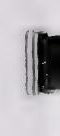

$\mathbb{E}$

1

1

1

L

E

1

L

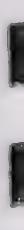

1 


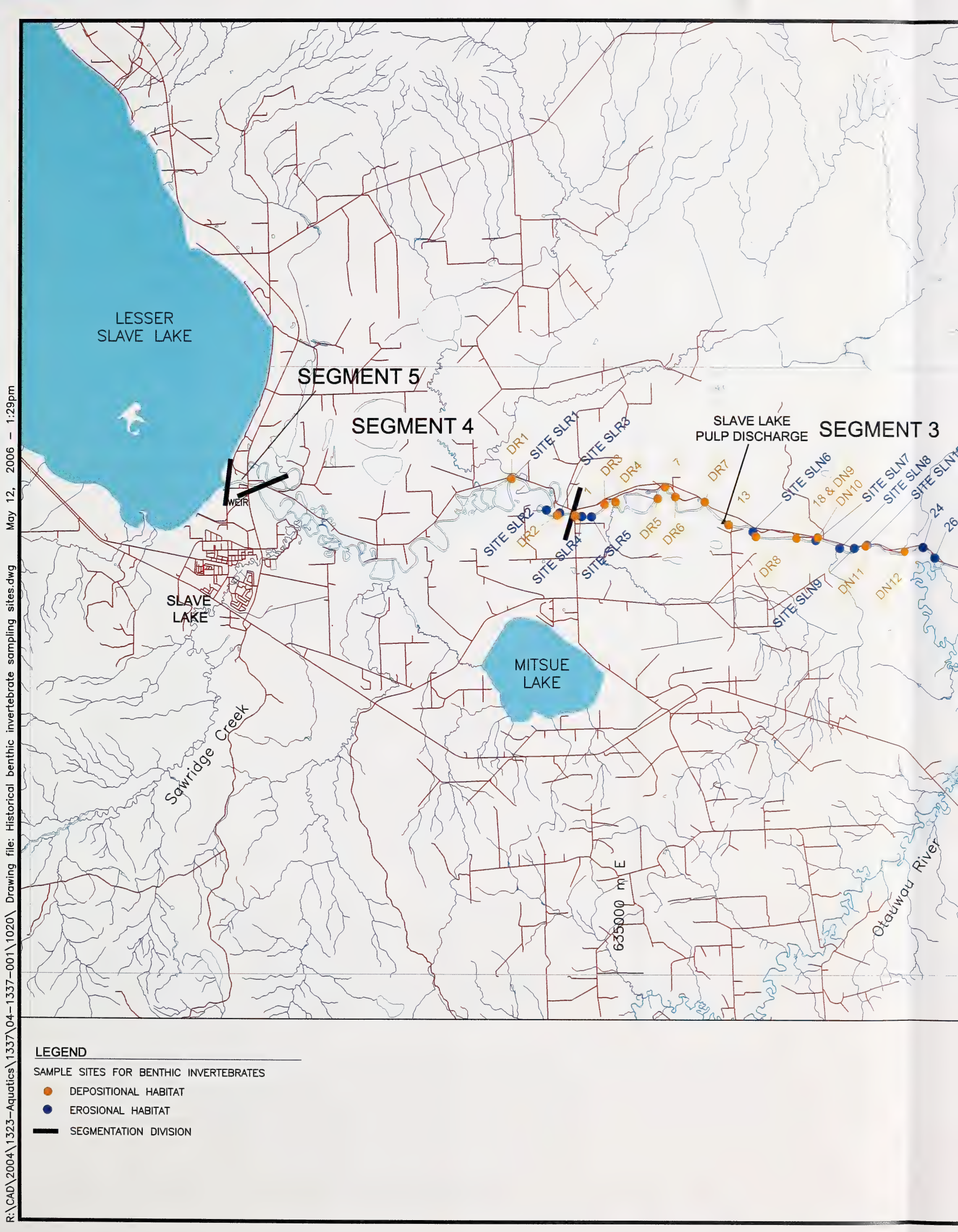


In total, 806 benthic invertebrate samples were collected, resulting in 154 site-specific data sets (one data set is a species list and corresponding abundance data collected at one site during one sampling event). Of these, 77 data sets were collected during the fall (September and October), 22 in the winter (November through March) and 55 in the spring (April and May). Even though a larger proportion of the sites were located in erosional habitat, more than half of the data sets were collected from depositional sites (i.e., 87 depositional sets compared to 67 erosional sets) because depositional sites were more frequently sampled. Most of the data sets (119) were collected in Segment 3. Considerably fewer data sets were collected in each of segments 1 (15 sets), 2 (15 sets), and 4 (5 sets).

All depositional sites were sampled using an Ekman grab of $15 \times 15 \mathrm{~cm}\left(0.023 \mathrm{~m}^{2}\right)$ bottom area. Erosional samples were collected using either a Neill cylinder or a Hess sampler (typically a $0.089 \mathrm{~m}^{2}$ bottom area). Mesh sizes used for screening samples ranged from 180 to $210 \mu \mathrm{m}$. Artificial substrates were used in one investigation; however, most of the substrates were lost before retrieval (EVS 1990).

\subsubsection{Importance of Flow and Winter Conditions}

In rivers, flow is one of the major physical determinants of benthic invertebrate habitat through its influence on channel morphology, substratum characteristics, current velocity and water quality (Resh and Rosenberg 1984). Seasonal high flows and spates may result in scouring, thereby directly reducing invertebrate abundance through increased drift, or by altering physical habitat features (e.g., removing fine sediments and benthic algae). At the other extreme, low flows may facilitate fine sediment deposition, or result in reduction of dissolved oxygen (DO) concentration, with subsequent effects on the benthic community.

During the winter, river flows are typically close to the annual minimum and under continuous ice cover. These conditions may exacerbate any effects resulting in reduced DO by limiting reoxygenation. As a result, DO concentration usually becomes the most important concern in relation to potential adverse effects on benthic communities.

In the Lesser Slave River, low winter flows combined with inputs of nutrients from Slave Lake Pulp and the Town of Lesser Slave Lake could potentially result in reduced winter DO, with the possibility of subsequent effects on benthic communities. Such effects would be reflected in 
reduced richness due to elimination of sensitive taxa, reduced abundances of sensitive invertebrates, and dominance by groups tolerant of low DO concentrations (usually oligochaete worms and midges). Despite this possibility, the water quality data summary (Section 4.3) did not find DO to be a critical issue in the Lesser Slave River, except under extreme low flow conditions, possibly because the depositional habitat in segments 3 and 4 is too short for development of low DO conditions.

\subsubsection{Data Summary Methods}

Benthic invertebrate data were obtained in electronic form, or data for summary variables were entered manually from hardcopy reports into Excel spreadsheets. It was beyond the current scope to enter original raw data or to conduct new statistical analyses on the data. Sample sites were plotted on a map to allow grouping by reach. Variables summarized included total abundance (number of organisms $/ \mathrm{m}^{2}$ ), richness (total number of taxa at the lowest level of identification) and percentages of total abundance contributed by major taxonomic groups. Trends in these variables over time and along the river were illustrated as bar graphs. Seasonal trends were also illustrated for selected sites.

\subsubsection{Segment 1}

In Segment 1, two sites were in depositional habitat and four were in erosional habitat. Data are available from winter, spring and fall. Site 87 , located in erosional habitat, was sampled the most comprehensively, with fall samples from 1989 to 1993 and 1995 (Figure 16). The benthic community at Site 87 was characterized by a variable but generally moderate total abundance $\left(13,000\right.$ to 36,000 organisms $/ \mathrm{m}^{2}$ ) and richness (22 to 59 taxa) during the fall (Figure 17). Invertebrate abundance was dominated by midges (Chironomidae), mayflies (Ephemeroptera), caddisflies (Trichoptera) and oligochaete worms (Oligochaeta) (Figure 17).

The two depositional sites were sampled in the winter. At these sites, total abundance ranged from 5,800 to 44,000 organisms $/ \mathrm{m}^{2}$, and richness was between 12 and 35 taxa. Both sites were dominated by midge larvae, which is typical of depositional benthic communities. 
Figure 17

Total Invertebrate Abundance, Richness and Community Composition at Erosional Site 87 in Segment 1 in the Lesser Slave River
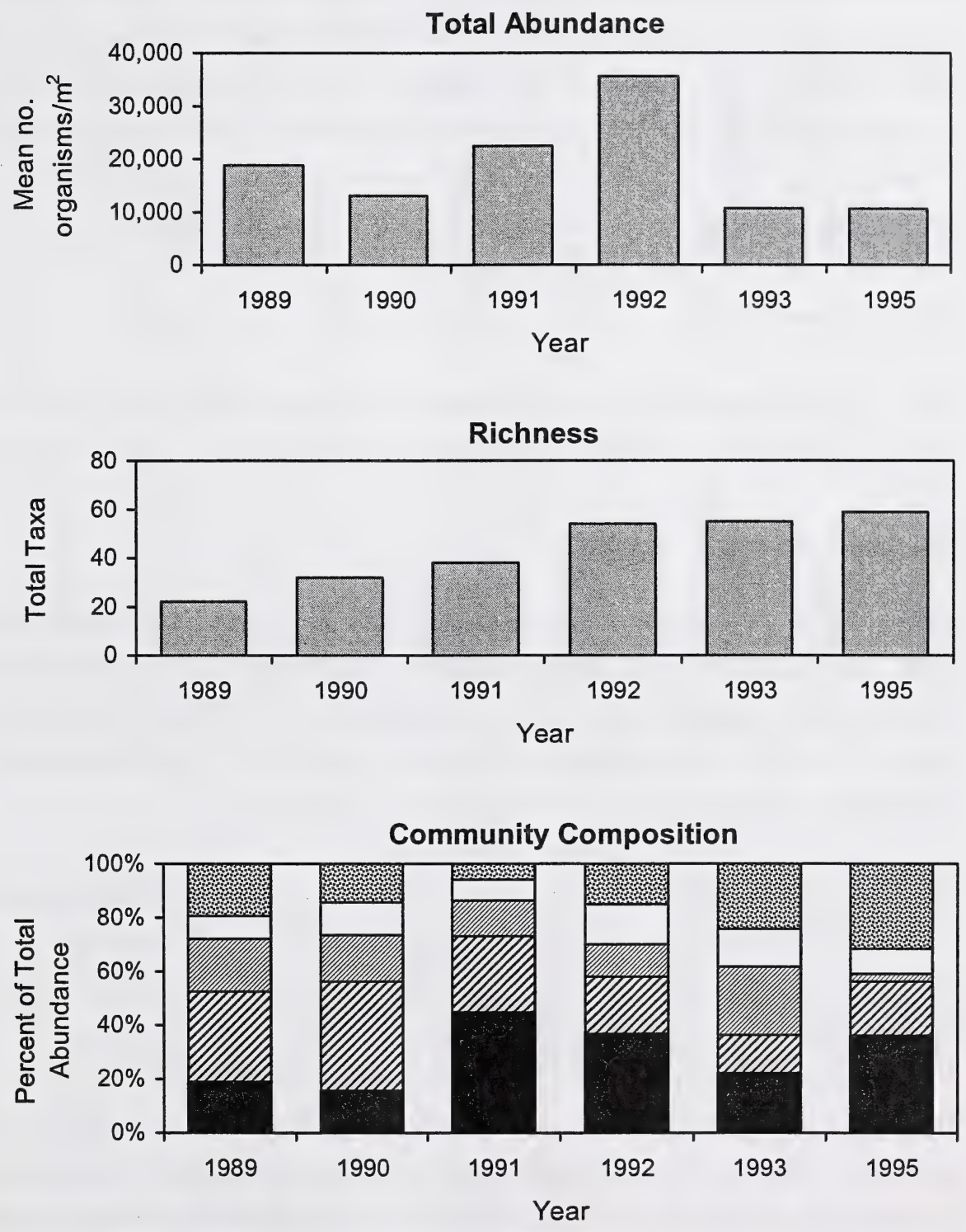

Chironomidae $\square$ Ephemeroptera 0 Trichoptera $\square$ Oligochaeta Other

Note: Richness values reported for 1989, 1990 and 1991 (EVS 1990, 1991, 1992a) were based on Chironomidae identified to the family level, and are thus not comparable to data from other years. 


\subsubsection{Segment 2}

In total, five sites were sampled in Segment 2, all in erosional habitat. Site 42 (see Figure 16) was investigated the most comprehensively, with samples collected during spring and fall from 1990 to 1994. Total abundance was variable, and ranged between 6,600 and 64,000 organisms $/ \mathrm{m}^{2}$ (Figure 18). Total richness ranged between 24 and 61 taxa; the lower values reflected family level identifications of chironomid midges in 1989, 1990 and 1991. Communities were dominated by midges, mayflies and caddisflies (Figure 18).

\subsubsection{Segment 3}

Most of the benthic invertebrate data available for the Lesser Slave River were collected in Segment 3. Summaries are provided separately below for erosional and depositional habitats.

\section{Erosional Habitat}

In total, 15 erosional sites were sampled in this segment, only 2 of which were sampled more than once. Sites 26 and 37 were sampled from 1989 to 1995, during most spring and fall seasons. Total invertebrate abundance was variable, ranging from about 1,400 to $>80,000$ organisms $/ \mathrm{m}^{2}$ (Figures 19 and 20). Total abundance in the spring was generally $<10,000$ organisms $/ \mathrm{m}^{2}$ while fall sampling generally yielded $>20,000$ organisms $/ \mathrm{m}^{2}$ (Figure 20).

Taxonomic richness ranged from 14 to 58 taxa (Figures 19 and 20). Earlier studies (EVS 1990, 1991, 1992a) identified Chironomidae to the family level; thus richness data reported for 1989, 1990 and 1991 were not comparable to data reported by subsequent studies. There were no discernable trends in richness over time, or between spring and fall.

There was a seasonal shift in community structure between spring and fall in most years (Figure 20). Community composition in spring was dominated by midges, with lower numbers of caddisflies, other dipterans and minor taxa. Fall communities were usually dominated by caddisflies. 


\section{Figure 18}

Total Invertebrate Abundance, Richness and Community Composition at Erosional Site 42 in Segment 2 in the Lesser Slave River
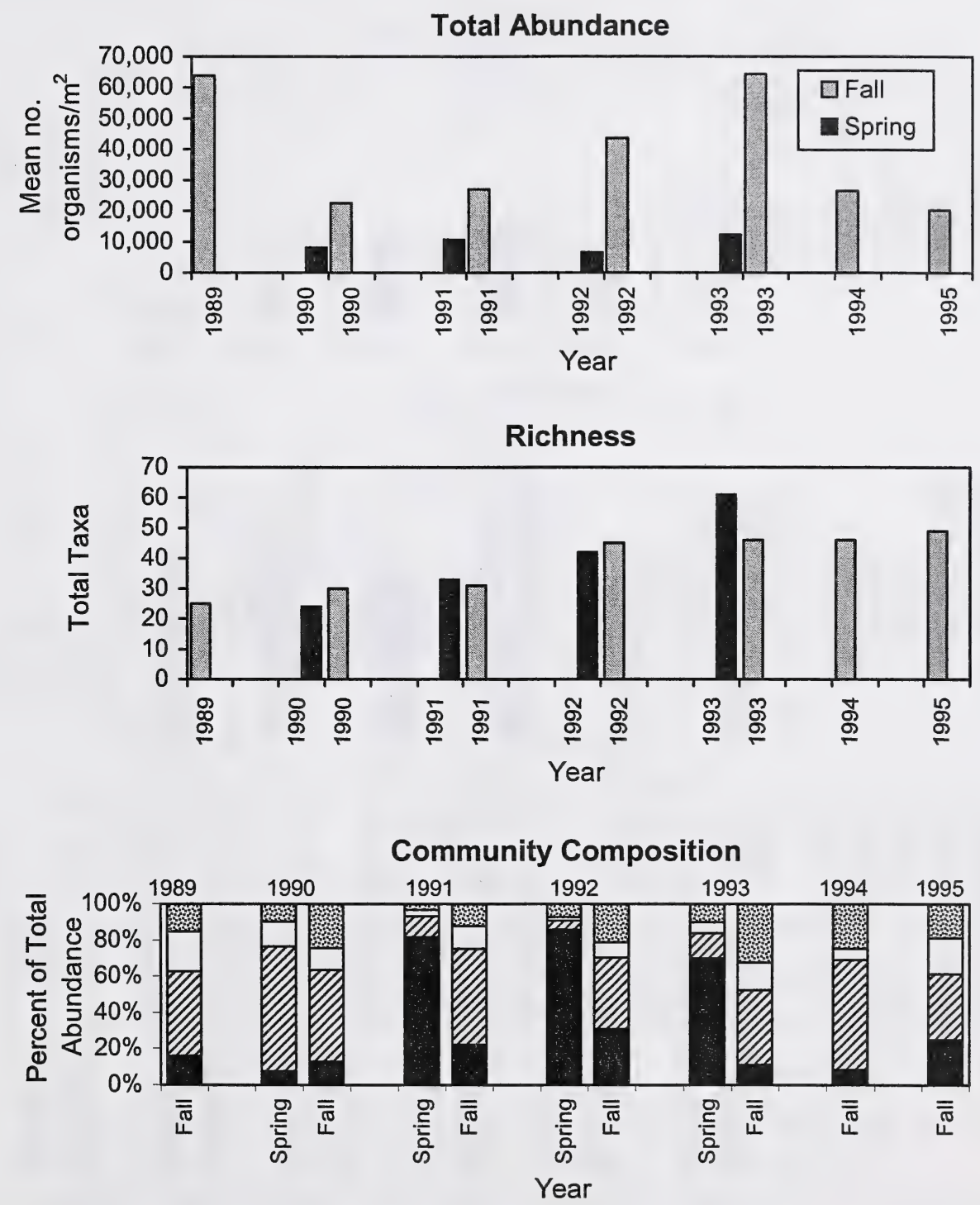

\section{Dhironomidae $\square$ Trichoptera $\square$ Ephemeroptera 圈 Other}

Note: $\quad$ Richness values reported for 1989, 1990 and 1991 (EVS 1990, 1991, 1992a) were based on Chironomidae identified to the family level, and are thus not comparable to data from other years. 
Figure 19

Total Invertebrate Abundance, Richness and Community Composition at Erosional Sites 26 and 37 in Segment 3 in the Lesser Slave River during the Fall
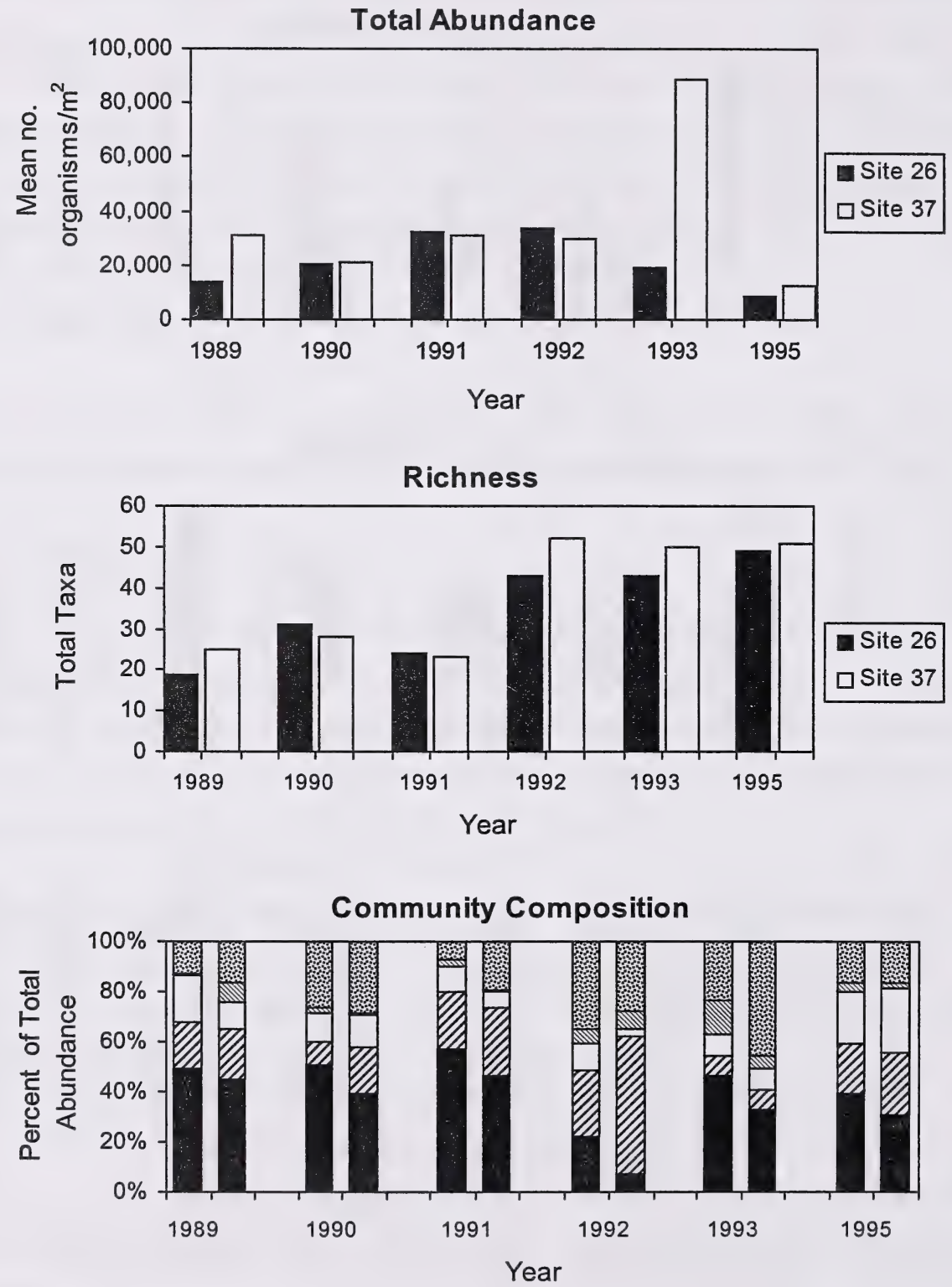

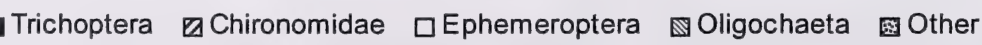

Note: $\quad$ Richness values reported for 1989, 1990 and 1991 (EVS 1990, 1991, 1992a) were based on Chironomidae identified to the family level, and are thus not comparable to data from other years. 
Figure 20

Total Invertebrate Abundance, Richness and Community Composition in Spring and Fall, at Erosional Sites 26 and 37 in Segment 3 in the Lesser Slave River

Total Abundance

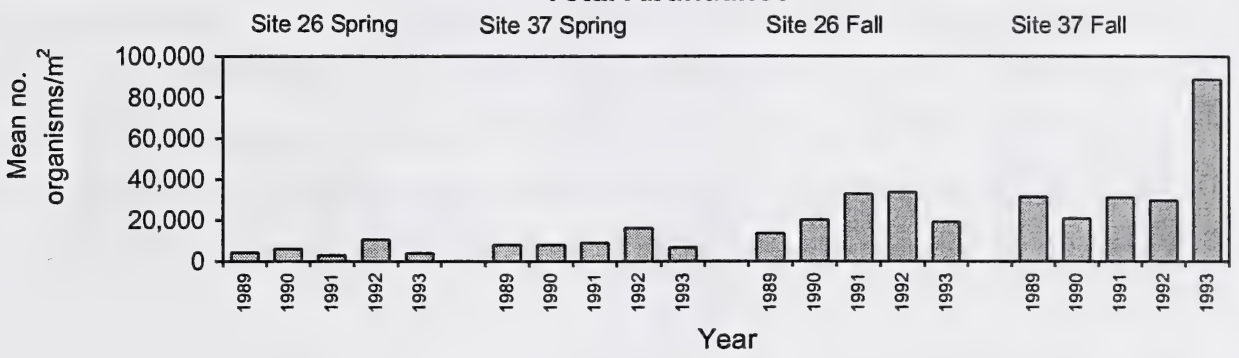

Richness

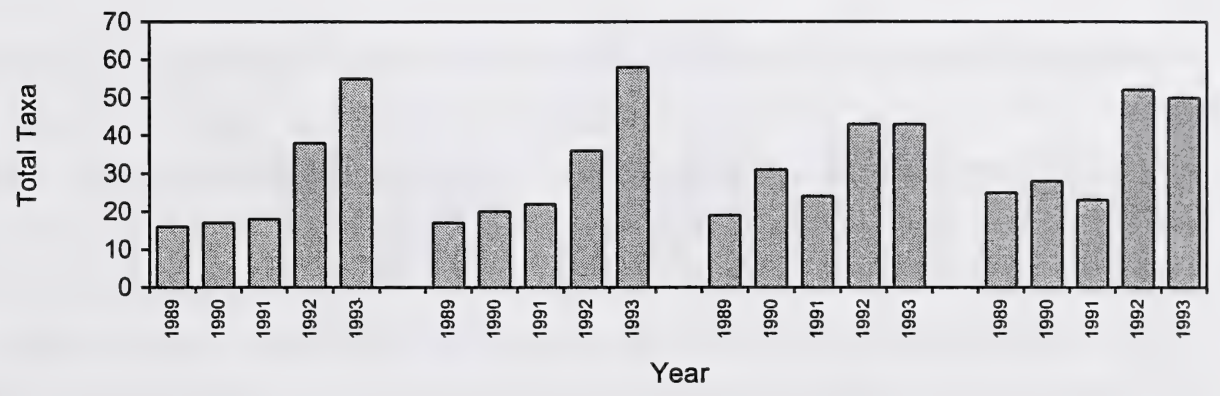

Community Composition

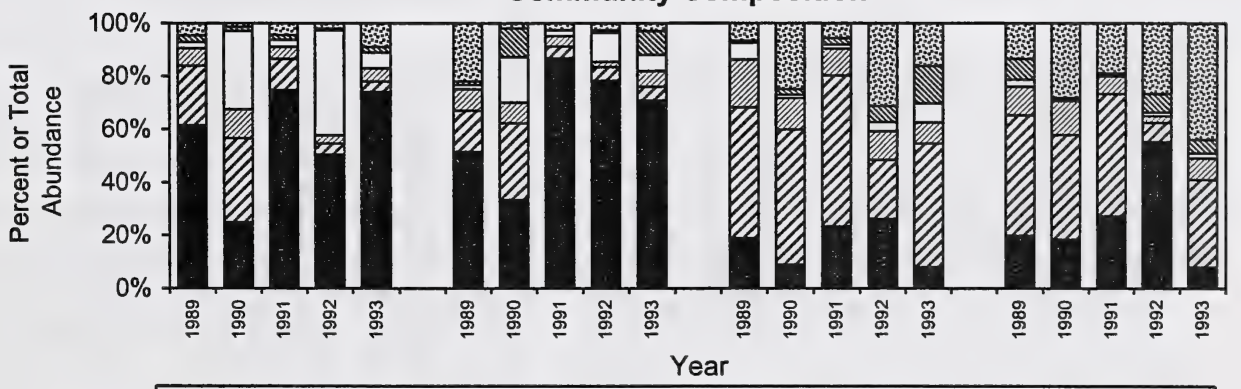

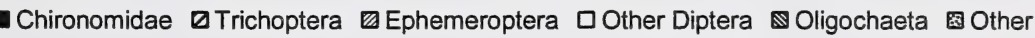

Note: $\quad$ Richness values reported for 1989, 1990 and 1991 (EVS 1990, 1991, 1992a) were based on Chironomidae identified to the family level, and are thus not comparable to data from other years. 
No erosional sites were sampled immediately upstream of Slave Lake Pulp in Segment 3 to evaluate upstream/downstream differences. However, Stantec and Golder (1999a, 1999b) collected upstream samples in Segment 4 as well as downstream samples in Segment 3 to evaluate biological effects during pulp mill EEM studies (Figure 21). Results of these studies were inconclusive with regard to pulp mill-related effects on the benthic community. Variability in abundance and richness upstream of the pulp mill discharge was similar to the downstream variation. Community composition was also similar above and below the discharge, although mayflies accounted for a larger proportion of the community at most sites downstream of the discharge.

\section{Depositional Habitat}

Fifteen depositional sites were sampled in Segment 3, six of which were sampled more than once. Sites 1, 7, 13, 18, 24 and 36 (see Figure 16) have several years of spring and fall data. Total abundance was variable and ranged from $<100$ to $>300,000$ organisms $/ \mathrm{m}^{2}$ (Figure 22). There was some seasonal variability, exhibited in an increase in abundance through the year. Total abundance ranged from low to moderate in winter $\left(<100\right.$ to $>14,000$ organisms $\left./ \mathrm{m}^{2}\right)$ and spring $\left(<100\right.$ to $>30,000$ organisms $\left./ \mathrm{m}^{2}\right)$, and from low to high in fall $\left(<100\right.$ to $>300,000$ organisms $\left./ \mathrm{m}^{2}\right)$. There were no discernible trends over time in total abundance. There was an upstream to downstream increase in total abundance during the fall in most years (Figure 22).

The total number of taxa observed at each site was variable and ranged from 2 to 48 in all seasons combined. Earlier studies (EVS 1990, 1991, 1992a) identified Chironomidae to the family level; thus richness data reported for 1989, 1990 and 1991 were not comparable to results of subsequent studies. There was almost no seasonal trend in richness, with similar ranges seen between winter ( 3 to 48 taxa) and spring ( 3 to 47 taxa); richness was slightly lower in the fall (2 to 39 taxa) (Figure 22). There was no obvious trend over time in richness.

Community composition was similar in all seasons. The benthos was dominated by midge larvae, followed by oligochaete worms and minor taxa. Other common groups included caddisflies, fingernail clams and roundworms. Temporal variation in composition was large and unpredictable, without a discernable trend over time. 
Figure 21

Total Invertebrate Abundance, Richness and Community Composition at Erosional Sites Upstream and Downstream of Slave Lake Pulp in 1998

Total Abundance
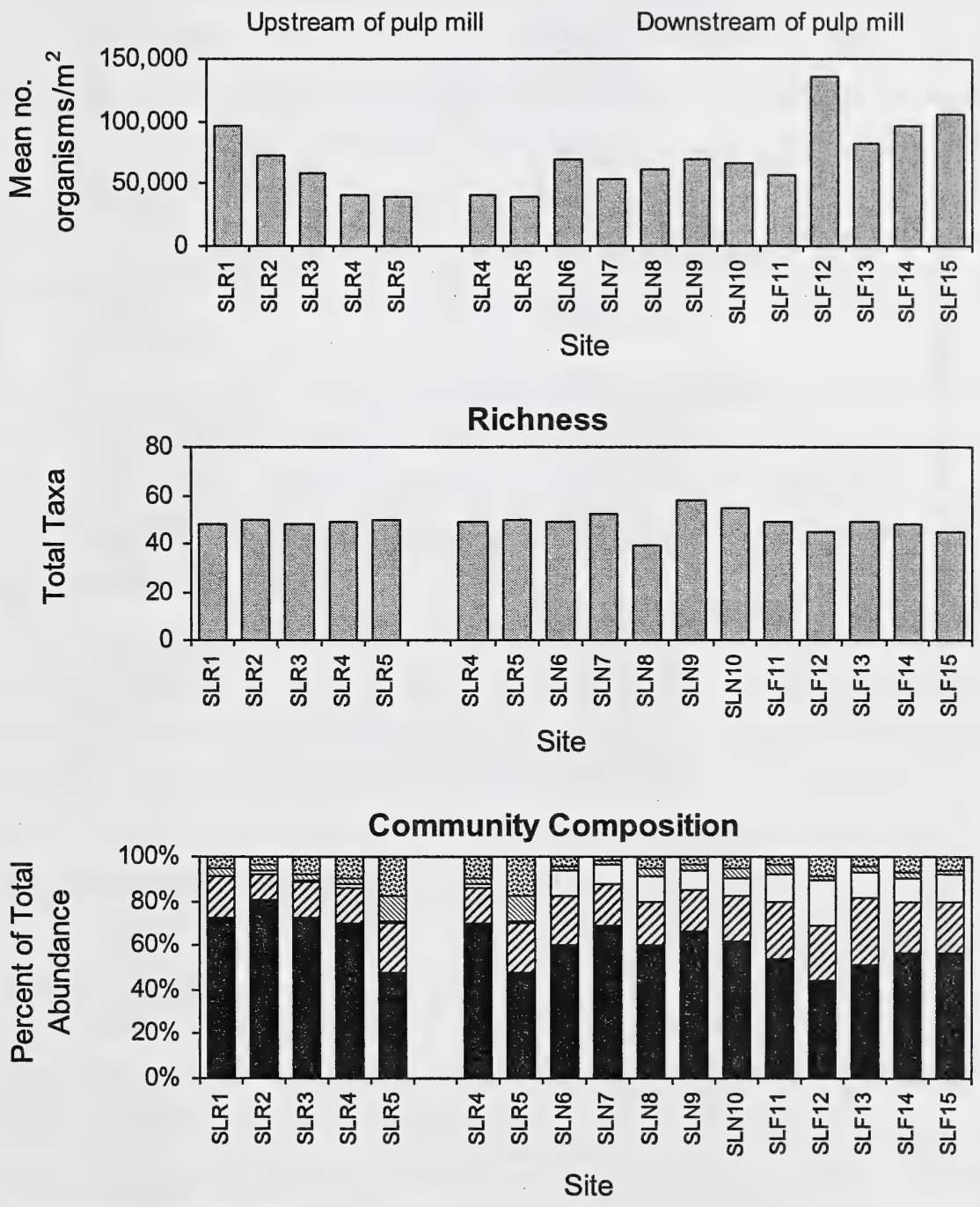

Trichoptera $\square$ Chironomidae $\square$ Ephemeroptera $\mathbb{\Delta}$ Other Diptera 圈 Other 

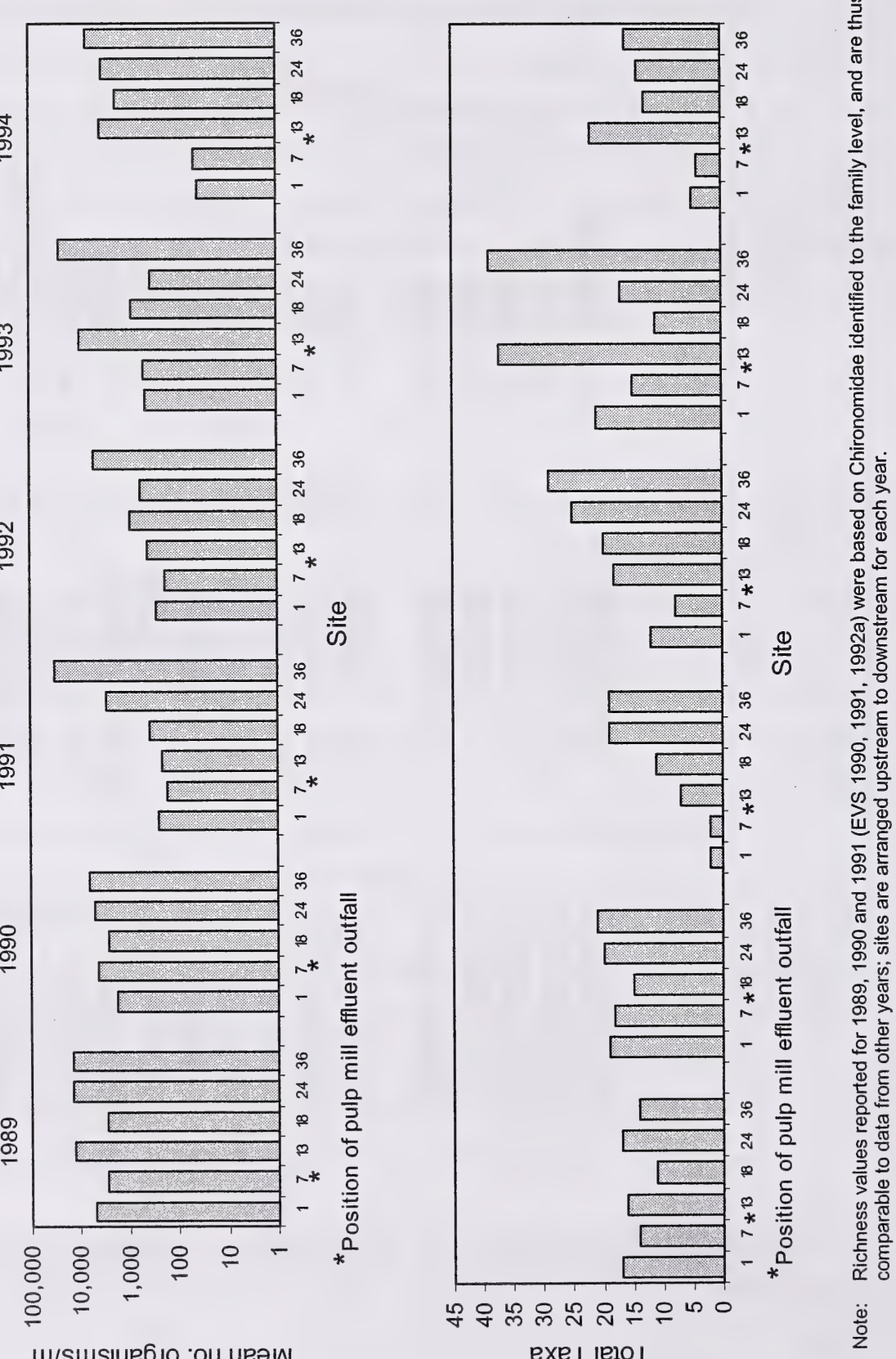
Pulp mill effluent appears to affect the benthic community in depositional habitat in the Lesser Slave River. Abundance and richness increased downstream of the pulp mill effluent discharge (Figure 22). Although this may be a result of increased productivity due to nutrient inputs, it may also reflect the gradient in habitat through Segment 3, from depositional to erosional. During the years after mill start-up (i.e., 1991 and thereafter), community composition below Site 7 shifted from being dominated by midge larvae to dominance by oligochaete worms (Figure 23); this may have been the result of increased organic inputs from the mill, which altered sediment composition and, potentially, dissolved oxygen regime near the bottom.

\subsubsection{Segment 4}

Five sites were sampled for benthic invertebrates in Segment 4. Three erosional sites were sampled in fall 1998 and two depositional sites were sampled in winter 2000. Abundance was generally high, $\left(59,000\right.$ to 239,000 organisms $\left./ \mathrm{m}^{2}\right)$ with the highest numbers in the winter (Figure 24). Richness showed little variability. Erosional sites had 48 to 50 taxa, while depositional sites had 35 to 43 taxa.

Community composition differed between the depositional and erosional sites (Figure 24). Depositional communities were dominated by midge larvae at one site, and by midges, oligochaete worms and roundworms (in the "other" category in Figure 24) at the other. The erosional community was dominated by caddisfly larvae and midges. However, oligochaete worms and roundworms were also common at erosional sites.

\subsubsection{Summary}

Benthic habitat in the mid to upper reaches of the Lesser Slave River is predominantly depositional, characterized by slow currents and fine-grained bottom sediments. Segments in the lower reaches have higher gradients and greater proportions of erosional habitat. The shift in habitat type from mostly depositional to mostly erosional begins near the mouth of the Otauwau River in Segment 3. 


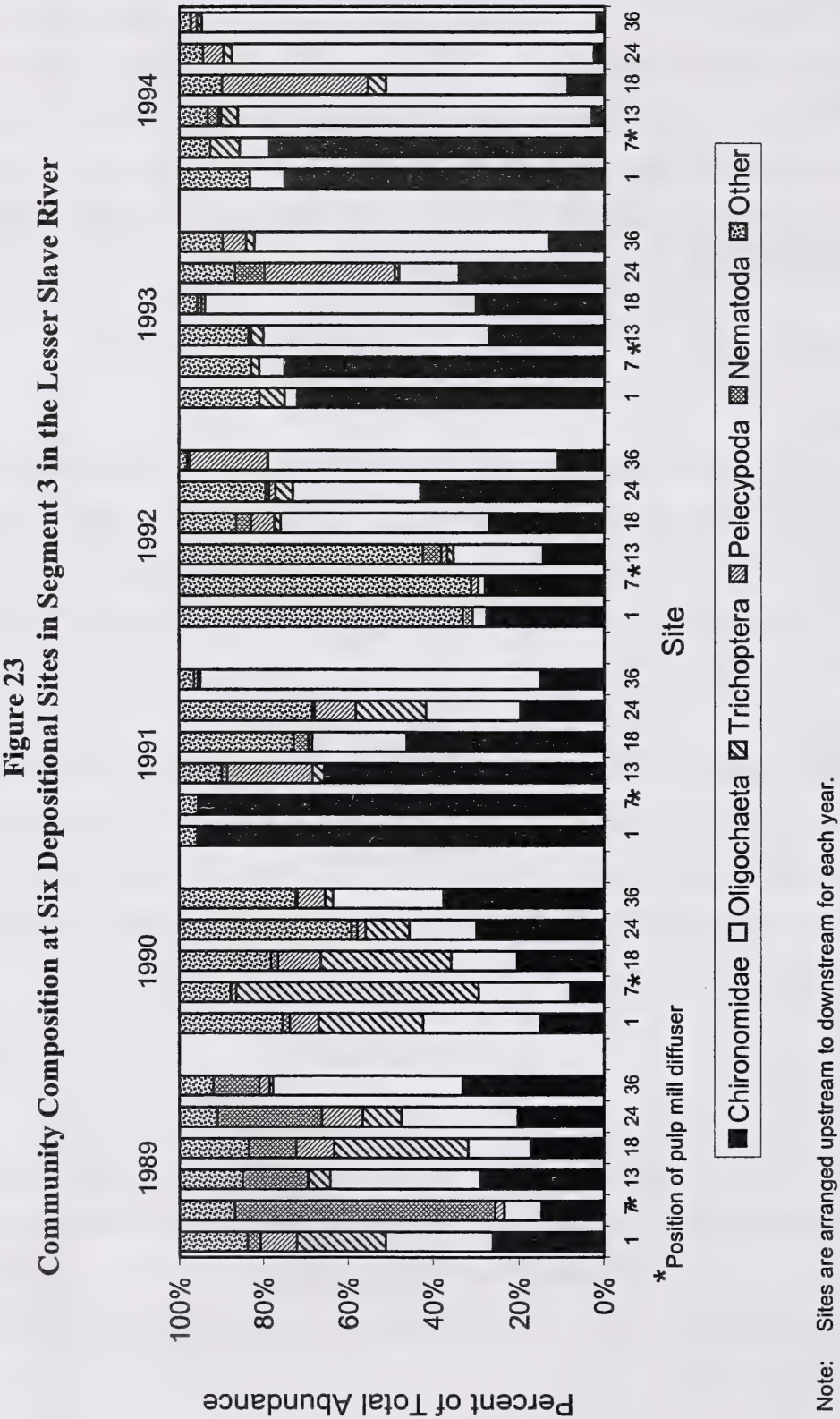


Figure 24

Total Invertebrate Abundance, Richness and Community Composition at Sites in Segment 4 in the Lesser Slave River
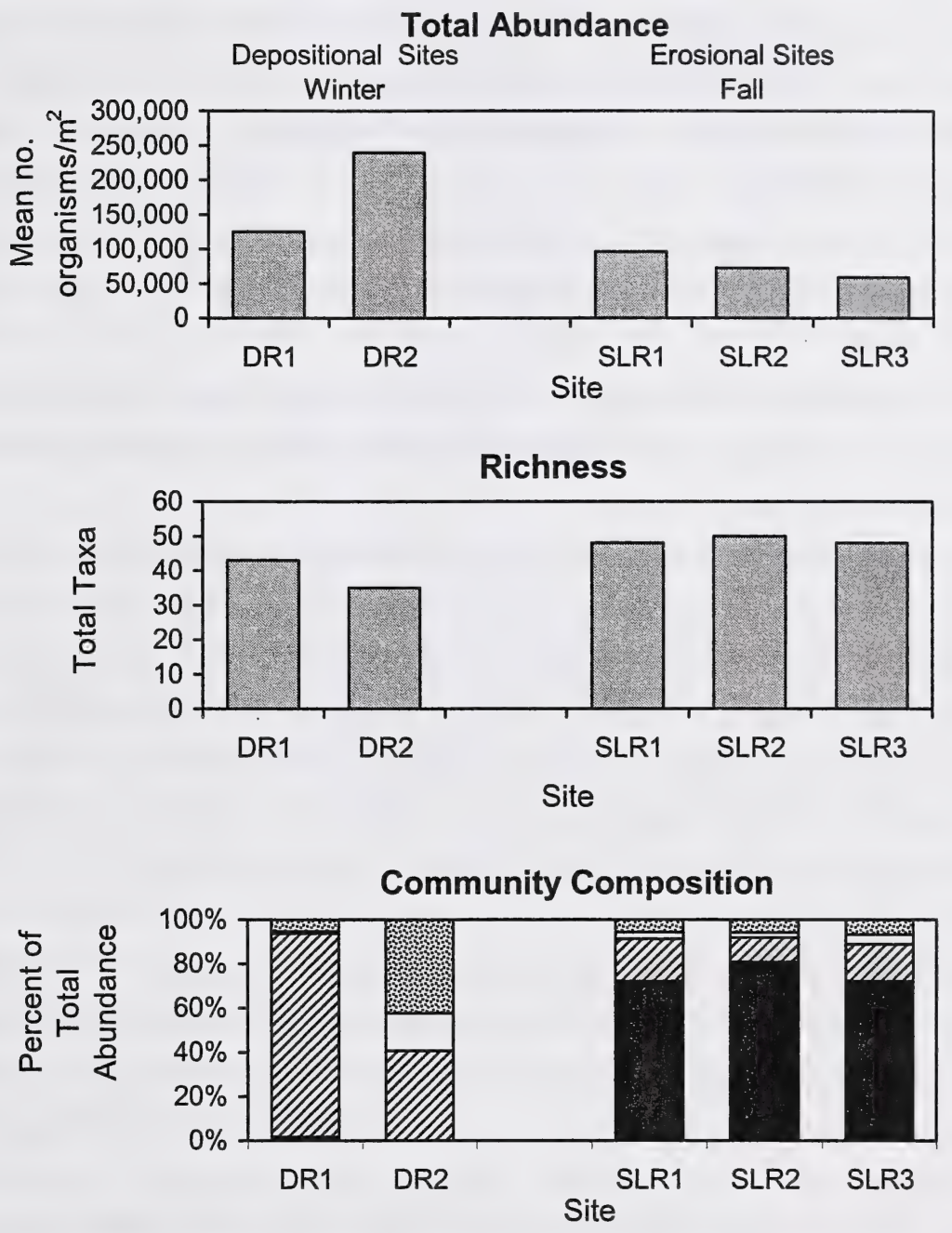

Trichoptera Chironomidae $\square$ Oligochaeta Other 
Most of the available benthos data were collected in Segment 3, during studies monitoring the effects of the Slave Lake Pulp discharge. Sufficient samples were collected to characterize both habitat types, and to evaluate seasonal and temporal trends in this segments. However, there are data gaps in other segments. There is some information available to evaluate seasonal and yearto-year trends at one site in each of segments 1 and 2, but it is not known whether these sites are representative of the benthic communities in these segments. Limited data are available for Segment 4 and there are no data for the short reach above the weir. Additional data deficiencies include the lack of baseline data to characterize natural biological condition before the weir was constructed, and absence of data to evaluate the effect of the municipal effluent.

In the upper reaches of the Lesser Slave River, the data summary documented communities typical of depositional habitats, characterized by variable but frequently moderate to high total abundance, and richness usually in the range of 20 to 50 taxa. Depositional communities were dominated by midges and oligochaete worms. Erosional communities were more common in the downstream reaches and were characterized by lower total abundance and higher richness. These communities were frequently dominated by caddisflies, and usually included moderate numbers of mayflies. Studies of depositional habitats in Segment 3 reported some effects of the pulp mill effluent, usually in the form of a greater proportion of oligochaete worms below the diffuser. However, there were no obvious effects of the pulp mill effluent on total abundance and richness in depositional habitat, or on any of the variables in erosional habitat.

Based on the available data, only general predictions can be made about likely community responses in the Lesser Slave River to further reductions of flow. The upper half of the river is depositional under current conditions, and is therefore unlikely to change its general character with any flow reductions. Nevertheless, further reductions in flow might alter benthic communities through reduced dilution of wastewaters discharged to the river and, possibly, increased sedimentation in erosional habitat. Under reduced flows, nutrient and carbon reserves (i.e., from decaying plant and algal matter) can increase in stream substrates and may result in lower dissolved oxygen levels relative to periods of higher flows. This type of an effect is unlikely in erosional habitat because of turbulent flows, which continuously re-aerates stream water, but may occur in depositional areas under severe flow reductions. Accumulation of fine sediments can also result in a decline in habitat availability for organisms other than those that burrow into bottom sediments. In general, habitat changes associated with flow reduction might 
result in a shift in community structure towards even greater dominance by a few depositional taxa.

Results of the data review and the general characteristics of benthic communities suggest that identifying indicator species for evaluating or monitoring flow-related effects is unlikely to be successful. Species-level identifications are lacking for most invertebrates because the environmental effect monitoring done to date did not require such detailed taxonomy. In addition, riverine benthic communities usually exhibit large variation in abundance and composition, even in the absence of disturbances, as they track changing habitat conditions over time. Therefore, rather than identifying indicator organisms, evaluation of changes in community structure with varying flows, while taking into account other habitat variables, would be more likely to provide useful information regarding flow-related effects.

\subsubsection{Recommendations}

At this time, there are insufficient data for a statistical evaluation of flow relationships with benthic community characteristics. Nevertheless, available data could be used for an initial, exploratory analysis of flow relationships, with the caveat that results may be inconclusive due to spatial and temporal resolution of available data, the typically high variability inherent in benthic invertebrate data and general community characteristics, which are already reflective of low and variable flow conditions. Most of the available data were collected during the seasons with low flow (fall and winter) and thus may reflect effects of low flows on the benthic community. Therefore, there are sufficient data to render an initial analysis of flow relationships worthwhile. Results of this type of analysis would also be useful to gain a refined understanding of data gaps and propose focussed studies to fill data gaps.

Therefore, one recommendation arising from the benthos data summary is an initial analysis of relationships between benthic community variables and flow, using available benthos data for selected sites. Seven years of data are available for a number of depositional sites, which is adequate for a largely qualitative analysis utilizing visual comparisons and correlations. The suggested procedure to arrive at the data to be examined in detail would involve reducing available data to sites or groups of sites within relatively short reaches that have been sampled repeatedly in the same season(s) using the same methods, or compatible methods. The raw data 
would have to be entered for these sites from hardcopies, or obtained from the original investigators, to allow derivation of a consistent set of benthic community variables (e.g., total abundance, richness, abundances of dominant taxa). At this point, community structure could also be summarized using multivariate methods (e.g., ordination). Flow data would be matched with the biological data and flow relationships could be examined using visual evaluation of scatter-plots and generating correlation coefficients between biological data and various flow statistics (e.g., mean flow for the time of sampling of for varying periods before sampling). Including the benthic community in the IFN evaluation is desired since they provide an important link in the function of aquatic ecosystems as a valuable food source to many fish species within the Lesser Slave River, such as mountain whitefish and forage fish species.

An additional recommendation involves the evaluation of the potential effects of the municipal discharge on the benthic community in the Lesser Slave River. Municipal effluents can have severe effects on the benthic community; however, results of the water quality data summary suggest that the nutrient levels in the river are not substantially elevated below the municipal outfall. In light of this information, it may be more efficient to first examine the nutrient loads contributed by the discharge to evaluate its likely significance to biological communities in the river, and proceed with a more detailed study only if such effects are deemed likely.

\subsection{Riparian Ecosystems}

Riparian vegetation is a key component of river and stream ecosystems and is essential for the fish and wildlife resources associated with rivers or streams. Riparian communities also help protect surfaces from erosion and naturally attenuate the magnitude and timing of flow (Rood and Mahoney 1991). Some of the plant communities that occur in riparian zones are also considered to be rare or special in some way (Allen 2003).

\subsubsection{Riparian Processes}

There are various types of riparian vegetation communities in Alberta, the most studied of which is the cottonwood forest in the southern part of the Province. River valley cottonwoods are phreatophytic (a deep-rooted plant that obtains water from a permanent ground supply or from the water table) and obtain moisture from the riparian water table. In general, the water table extends 
horizontally from the river and fluctuates annually. Cottonwoods are adapted to the natural variation in water table levels. Negative impacts on riparian cottonwood forests have been caused by a variety of activities including water diversion (Rood and Mahoney 1991).

The presence of the flow control weir and the channelization of the upper segment of the Lesser Slave River, although not capable of making substantial changes to the flow regime as highlighted in the hydrology section, warrant that the riparian ecosystem should be considered during scoping of an IFN study for the Lesser Slave River.

\subsubsection{Biogeographic Information}

The Lesser Slave River spans the Dry Mixedwood and Central Mixedwood subregions of the Boreal Forest Natural Region (Strong and Leggat 1992). These Subregions transition between each other and hold many vegetation community types in common. The differences are largely in the proportion of various vegetation types and other landscape features. Trembling aspen (Populus tremuloides) is the characteristic forest species occurring in both pure and mixed stands. Balsam poplar (Populus balsamifera) frequently occurs with aspen, especially on moister sites in depressions and along streams. Paper birch (Betula papyrifera) also occurs commonly with aspen, more commonly in the Central Mixedwood Subregion (ANHIC 2004).

Typically, deciduous forests eventually mature to coniferous forests, with white spruce (Picea glauca) replacing deciduous trees as stand dominants. Fire and meandering floodplains limit the development of climax forests and pure deciduous stands are common in the southern part of the Subregions. Coniferous species are more common further north, with mixed stands of aspen and white spruce being widespread (ANHIC 2004).

Peatlands are common and extensive throughout the Central Mixedwood and less common in the Dry Mixedwood Subregion. Peatland complexes typically contain both nutrient-poor, acidic bog portions, dominated by black spruce (Picea mariana) and more nutrient-rich fens, containing tamarack (Larix laricina) (ANHIC 2004).

A data review was conducted for available information to complement an IFN study of the Lesser Slave River and, if possible, to determine at a coarse level, if riparian vegetation may be changing 
and the direction and type of future studies required to address information gaps. Available literature, maps, databases and aerial photographs were reviewed for their applicability to the study.

\subsubsection{Hydrological Influence on Riparian Ecosystems}

River hydrology is a primary factor in the development of riparian vegetation. The availability of water for nutrient transport and as a reproductive transport source makes flow and volume important considerations for riparian vegetation.

The review of the hydrology of the Lesser Slave River in Section 4.1 shows that the regulated flow regime has resulted in slightly higher flood flow peaks and reduced flows for the months of April though June and September through November. The presence of the weir has not, to date, had a pronounced effect on the flows of the river.

\subsubsection{Riparian Geomorphology}

As a component of the lake stabilization project, the upper segment of the Lesser Slave River was straightened by cutting off meander bends. From aerial photographs, these developments appear to have stopped the meander processes in the upper segment, at least over the last 20 years, which was a natural function of the river.

Based on a comparative airphoto analysis of pre-weir (1980) and post-weir (2002) conditions, the most substantial changes to riparian geomorphology since the weir was constructed and the channel was straightened are:

- In segments 1-3, there are no discernable changes to river morphology.

- In Segment 4, channel straightening is evident along much of this reach as a result of the constructed cutoffs. There has not been a return to a meandering configuration and channel bed degradation has occurred along this reach, resulting in further channelization.

- From the lake outlet to the weir, the presence of the weir appears to be limiting the water available to the oxbow lakes above it. There is also vegetation developing 
along exposed banks, although this may be due to the recent series of drier years.

Channel bed aggradation has occurred upstream of the weir.

Overall, changes in channel morphology appear to be a slow process on the Lesser Slave River. This is evidenced by the location of historical campground areas along the river (Schultz and Bentz 1990). These campsites were found in locations very near the water's edge, indicating a lack of change in river morphology over time.

Ice jams may also have a role in riparian morphology and the establishment of vegetation on the Lesser Slave River. It is suggested in Section 4.2 that major ice jamming does not occur on the river. The occurrence of ice-scouring events is often needed to expose new areas for recruitment of riparian vegetation. Alternatively, ice jams on boreal rivers have been known to create a high river stage, differing from the typical high open-water flow level (Church and North 1996). Ice jams and flooding may limit the establishment of riparian vegetation to this high stage water level, but this does not appear to be the case on the Lesser Slave River.

\subsubsection{Literature Review}

A literature search was carried out, specifically for the effects of flow regulation on the Lesser Slave River and northern boreal streams. The investigation of the current literature on riparian ecosystems of the Lesser Slave River rendered few and only marginally useful results. There are many reports that describe the function of Albertan riparian ecosystems and impacts to these systems from agricultural and industrial development (e.g., Rood and Mahoney 1991; Tellman et al. 1993). However, these reports generally focus on cottonwood forests and southern Alberta river systems, which are not applicable to the Lesser Slave River and other boreal rivers.

Rood (1996) suggested that northern boreal riparian forests may not be as dependant on surface water flows as southern cottonwood forests due to differences in water availability and the interaction between surface water and the riparian water table. In southern arid regions, survival of the riparian community is dependant in part on trees maintaining access to the riparian water table, which is directly linked to the surface water level. High flows are critical for establishing nursery sites to allow seedling establishment and recruitment to occur. High flow events are still likely critical to the development of northern riparian ecosystems; however, the link between 
lower flows and riparian survival in northern forests has not been established. In northern boreal regions where precipitation is more abundant than in the arid south of Alberta, well timed precipitation events may be more beneficial to riparian ecosystems and alleviate the dependency of the riparian community on instream flows (J. Mahoney, pers. comm.).

The distribution of trees can be viewed as a biological indicator of riparian health on a river (Rood 1996). In northern areas, predictions and observations of effects on the riparian community are not so much of die-back resulting from reduced flow, as vegetation species and composition shifts. These effects will vary greatly from reach to reach. Gravel beds versus sand beds will have different responses depending on distribution and connectedness and species present (Church and North 1996). However, since forested stands have generally continued to develop, the Lesser Slave River riparian zone seems to have adapted to the weir and channelstraightening modification, although it may still be to soon to confirm this hypothesis.

\subsubsection{Alberta Vegetation Inventory}

The Alberta Vegetation Inventory (AVI) is a graphical database of tree stand attributes based on aerial photographs (AEP 1991). Polygons of forest stands are created and stand attributes recorded in a linked database. Developed primarily as a forestry planning tool, AVI can be applied to mapping exercises by grouping like polygons together. Together with field verification, AVI can be used to classify a larger area by interpolating field measurements to like polygons. This can be applied to IFN studies for mapping floodplain ecosystem types.

AVI is available for most, but not all of the land adjacent to the Lesser Slave River. This inventory provides some of the information necessary for interpreting riparian ecosystems. By evaluating the relationships between the Lesser Slave River riparian zone and field data, a better understanding may develop of the potential impacts of water management activities on riparian ecosystems.

\subsubsection{AVI of the Lesser Slave River}

For the Lesser Slave River IFN scoping study, four AVI townships were obtained for a preliminary assessment of the riparian vegetation. A township in each of the four segments 
downstream of the weir allows a preliminary characterization of the riparian vegetation in these river segments.

The vegetation of the Lesser Slave River can be described as deciduous forests directly along the river, flanked primarily by wetlands. The riparian forests are primarily aspen dominant, with white spruce being the sub-dominant species. There are areas where there are balsam poplar and paper birch as tertiary species.

\subsubsection{Aerial Photographs}

Aerial photograph interpretation can also be useful in IFN studies. By comparing aerial photographs from two time periods, changes in riparian systems and vegetation can be identified. Aerial photographs are readily available for different years and seasons on the Lesser Slave River. Two sets of aerial photographs were selected which included both pre- and post-weir development periods (1980 and 2002, respectively). The 1980 set is at a scale of 1:8000 and are printed in true colour. The 2002 set are panchromatic photos, flown at a scale of 1:20 000. Although the scale and film used for the two sets of photos are different, this discrepancy does not affect the interpretation process in assessing changes in the riparian ecosystems between the two periods.

The 1980 photos were taken in late July, when the mean monthly flow was $66 \mathrm{~m}^{3} / \mathrm{s}$. The 2002 photos were taken in late August, when the mean monthly flow was $13 \mathrm{~m}^{3} / \mathrm{s}$.

\subsubsection{Aerial Photograph Reach Specific Information}

Analysis of the aerial photographs reveals that there does not seem to be any substantial effect on downstream riparian vegetation over the 22 -year time period since the weir was installed. It is apparent that vegetation and forests have continued to develop along the river, as many stands have expanded in size and height.

\section{Segments 1, 2 and 3}

Forest stands along the river have developed over time, and there does not appear to be any great changes in the morphology of the river. There are no substantial changes to riparian vegetation along these segments. 


\section{Segment 4}

The cut-offs have created oxbows and large meanders that are presently drying as regular flow apparently no longer reaches them. There is no evidence of woody vegetation invading these oxbows, as they remain largely as meadows or unvegetated. There is evidence of stand expansion, and limited evidence of establishment or recruitment along the cut-offs.

There is little evidence to demonstrate that the straightening of the river has had a negative impact on the growth of riparian vegetation. The point where the river runs through Sawridge Indian Reserve $150 \mathrm{G}$ and the areas immediately east and west have perhaps seen the most extensive redirection of the river. At this point, there are two hairpin turns in the river have been bypassed by the straightening. Within these points, the stands appear to have died-back, but this may also be a result of cleared land to complete the cut-offs. The larger of the two does show some stress in the stand, but this is possibly due to residual stress from construction rather than changes in river morphology. Channel degradation downstream of the weir that has occurred post weir construction may also result in a lowering of the water table in the adjacent riparian zone and could result in drought stress and would be worth investigation to confirm the cause of stress.

Prior to channelization, the changing morphology of the meanders in this segment appears to have been very active, as there is some evidence of drying/changing morphology between the 1977 air photos taken to prepare the NTS map sheet and the 1980 photos. Field investigation in this segment is required to provide additional information on the condition of the riparian community within this segment and to indicate if any changes or stress in the riparian community are due to flow regulation or channel degradation.

\section{Segment 5}

The 2002 photos indicate vegetation has established on formerly submerged areas, especially on the north bank of the inlet, where trees and shrubs have had time to establish. The morphology has changed to a much narrower channel in this reach. There is a dried back channel that remains unvegetated in this segment.

The oxbow lakes above the weir have experienced some change. Trees in the oxbow area have continued to develop, as evidenced by stands that are taller and denser. They retain their 
geometric shape on the landscape, which has been influenced by the movement of the oxbow across the landscape. This is a common feature of forested areas along river floodplains.

The eastern-most oxbow displays the most extensive evidence of drying on the river. There seems to be complications with flow patterns between this oxbow and the large wetland to the north. The photos suggest that there has been some drying of this large wetland north of the oxbow lakes, as darker areas revealing wetness have diminished. The interpretation of this large wetland requires verification, as AVI shows that much of its area was previously burned (circa 1953).

\subsubsection{Further Research Recommendations}

At this stage of investigation, very little can be said with certainty on the effects of regulated flows on the riparian ecosystems of the Lesser Slave River. However, the evaluation of the hydrology indicates changes in flow have been minor, and the present analysis indicates substantial changes to the riparian vegetation have not occurred. However, the stress observed in some stands within Segment 4 from the airphotos at the locations of the meander cutoffs should be investigated to determine if the stress is a result of man-made factors or potentially due to drought stress as a result of channel degradation.

A field investigation should be conducted to confirm if the weir and channelization of the river and resulting regulation of flows is having an impact on riparian vegetation. From the aerial photograph and AVI assessment in this report, it appears that forests are developing in-situ, and that restricted meander processes in Segment 4 are not allowing for the development of gallery forests. This could mean that gallery forests along the Lesser Slave River could develop into banding/edge forest. A gallery forest has a diverse age range, and consequent diversity in composition, as this allows for differing growth conditions. A banding/edge forest becomes quite homogeneous over time, trending toward climax forest species and reducing diversity. A banding/edge forest may create conditions that have firmly rooted trees right up to the river bank, which compound the effects of channelization.

From the aerial photograph investigation, the increase in human development seems to have had a more visible impact to riparian vegetation than the weir and channelization. Between 1980 and 
2002 there is a visible increase in the amount of forestry, residential and agricultural developments along the river. Additionally, there have been several adjustments to the routing of Highway 2A along the Lesser Slave River. A look at the fragmentation of riparian communities could be assessed, and a study of the former highway routes could be an indicator of the resiliency of the riparian areas to restore themselves after disturbance.

\subsection{Fish and Fish Habitat}

Habitat within the Lesser Slave River varies from the outlet of Lesser Slave Lake to the confluence with the Athabasca River. From the outlet of the lake downstream to the Saulteaux River confluence, the Lesser Slave River is a low gradient sand-bed river. Large oxbows, cutoff from the mainstem during channel straightening and backwaters are important habitat features of the upper reaches. Below the Saulteaux River, the slope increases and the river exhibits a predominantly gravel/cobble substrate with riffle/pool sequences. Deep pools are present and are important habitat features in the lower reaches of the Lesser Slave River.

The Lesser Slave River provides a regionally important fishery, and a migratory link between Lesser Slave Lake and the Athabasca River. With the construction of the weir in 1982, a potential barrier to fish movement between Lesser Slave Lake and the Athabasca River was created. Fish passage was facilitated in 1984, involving a combination of two Denil and a single vertical slot passage structures. The original Denil fishways were retrofitted with a newly designed Denil structure in 2000. Fishway use was monitored after the original fishways opened (Schwalme et al. 1985) and after the retrofit was operational (Eco-Logical 2000).

\subsubsection{Overview}

The following provides a general summary of existing information concerning fish habitats and fish populations in the Lesser Slave River, as well as a more detailed summary for eight key fish species based on abundance, importance to the fishery and ecosystem importance. The eight key fish species recommended for consideration in the IFN study are:

- walleye (Sander vitreum);

- northern pike (Esox lucius);

- lake whitefish (Coregonus clupeaformis); 
- mountain whitefish (Prosopium williamsoni);

- goldeye (Hiodon alosoides);

- longnose sucker (Catostomus catostomus);

- white sucker (Catostomus commersoni); and,

- $\quad$ shiner species, both spottail (Notropis hudsonius) and emerald (N. atherinoides).

The existing fisheries information was summarized for the key species based on the various life stages, defined as follows:

- spawning;

- $\quad$ fry (young-of-the-year);

- juvenile (immature fish other than fry); and,

- $\quad$ adult (sexually mature).

This summary details available information relating to the use of the Lesser Slave River by the eight key species. The focus is on the following life-history activities and associated timing:

- $\quad$ spawning (reproductive activities by adult fish);

- $\quad$ nursery (habitat used by fry);

- rearing (habitat used by juvenile fish);

- feeding (non-reproductive activities by adult fish);

- overwintering (winter use by all life stages); and,

- migration (seasonal movements for all life stages).

The spatial distribution of the key species within the Lesser Slave River was assessed based on the results of existing fisheries sampling efforts in the five river segments included in the IFN study (Figure 25). Where possible, migratory patterns of fish were inferred based on typical behaviour of the species. 


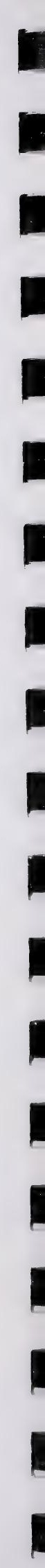




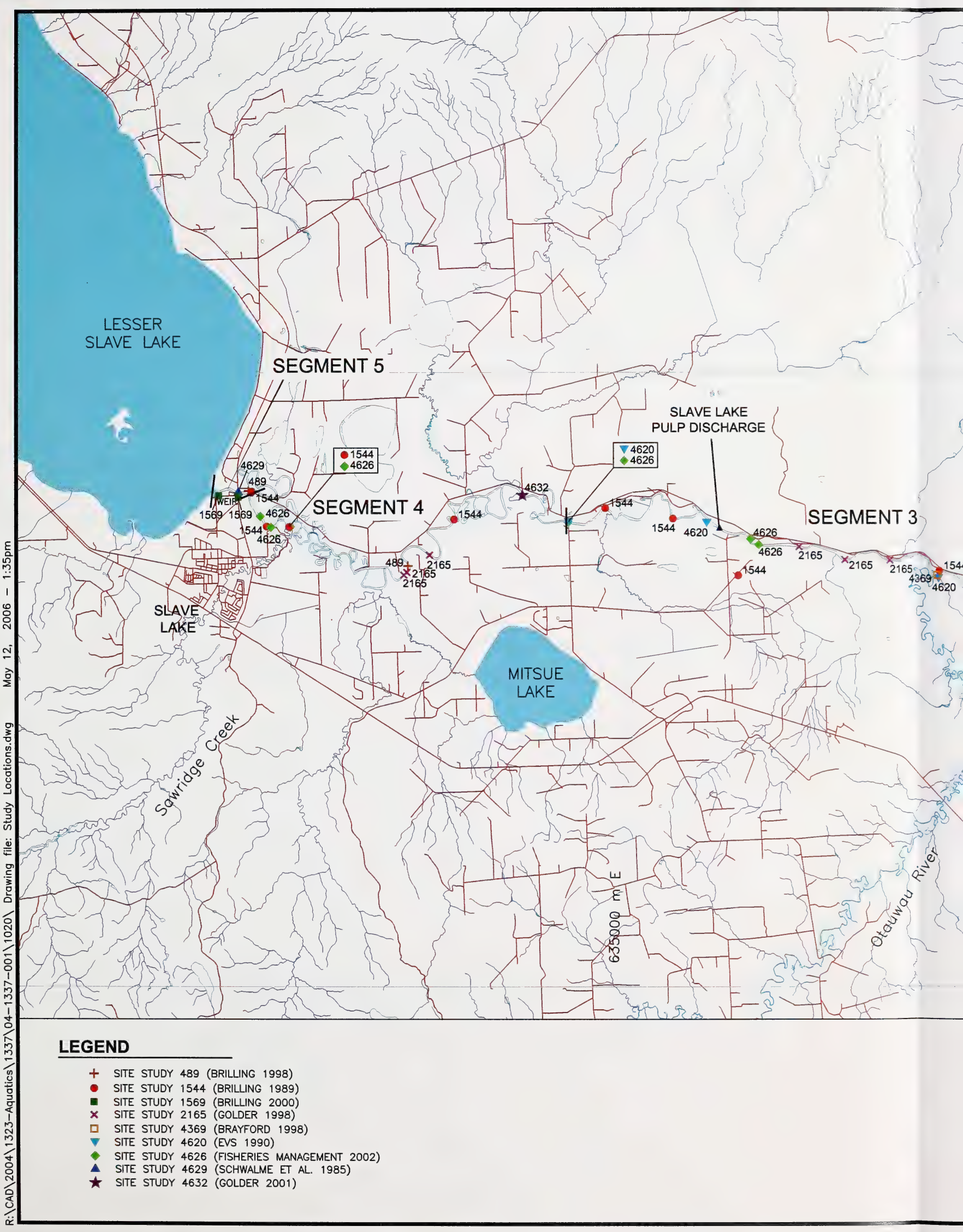



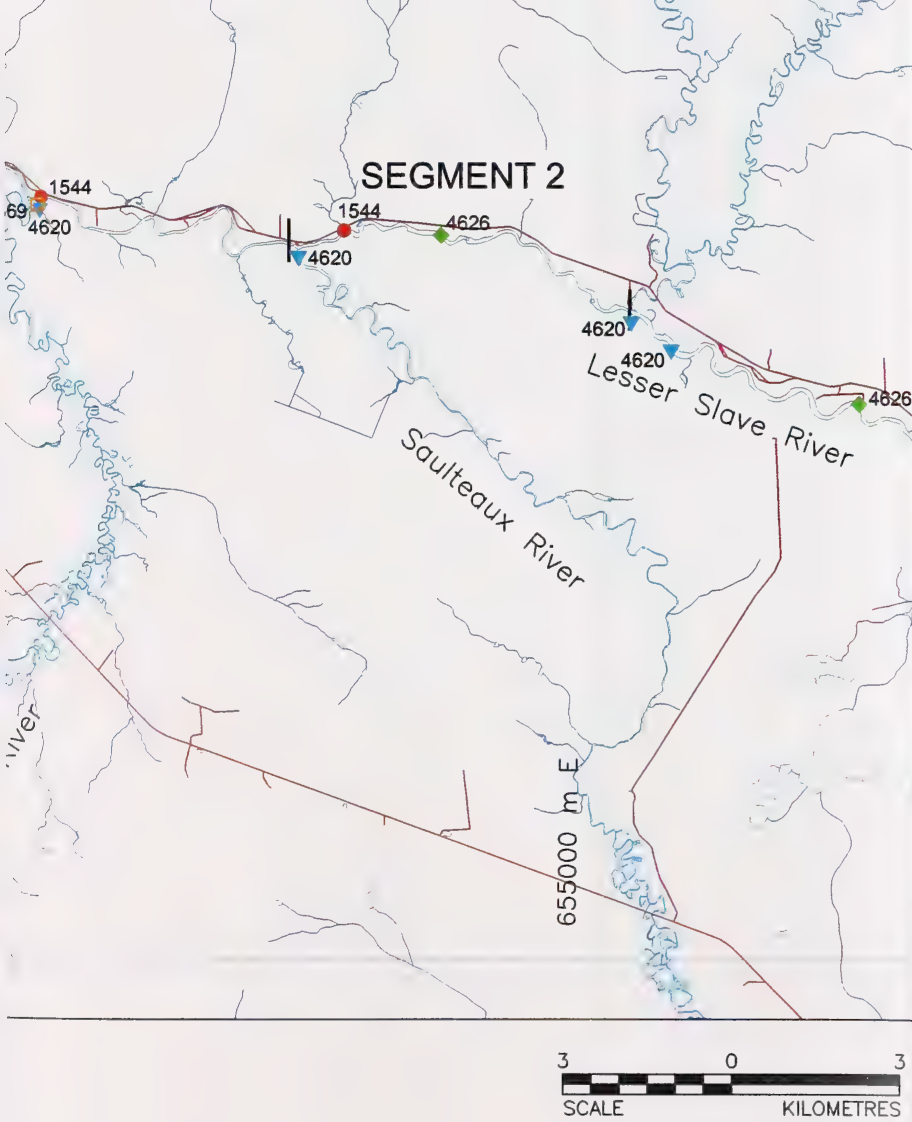

SEGMENT 1 4626,1544

\section{FAWCETT LAKE}

$6135000 \mathrm{~m} \mathrm{~N}$

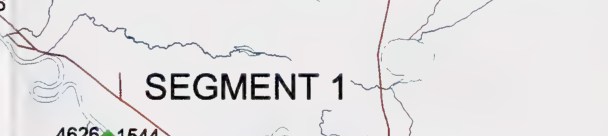

REFERENCE

BASE MAP PROVIDED BY ALBERTA SUSTAINABLE RESOURCE DEVELOPMENT NATIONAL TOPOGRAPHIC SERIES J/10, 11, 14,15, 16, O/1, 2, 3, 7, 8, 9, 10 AND $P / 3,4,5,6,11,12$.

NAD 83 UTM ZONE 11.

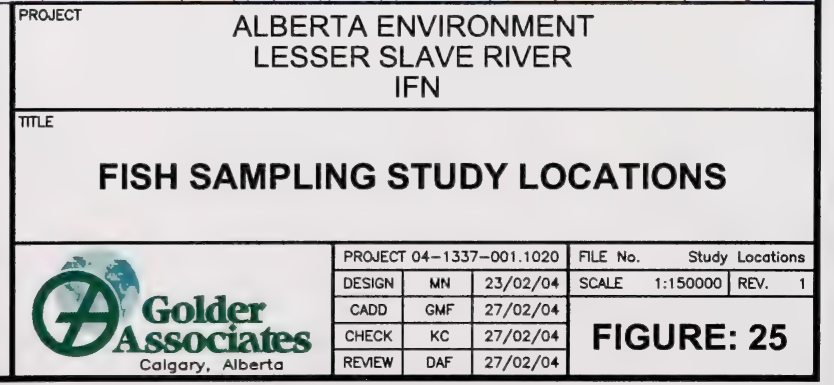




\section{Existing Information}

Numerous fisheries studies have been conducted on the Lesser Slave River and its tributaries since the 1960 s, although a majority of the available information has been collected in the last two decades after the construction of the weir. An evaluation of pre-weir and post-weir fish movements is difficult due the lack of pre-development data.

The information sources that provide data concerning fish habitats and fish populations in the Lesser Slave River are listed in Section 4.6.12. Data summaries were largely extracted from the provincial Fisheries Management Information System (FMIS) database provided by Alberta Sustainable Resource Development, and consisted largely of the results of nine inventory studies (Brayford 1998; Brilling 1989, 1998, 2000; EVS 1990; Fisheries Management Division 2002; Golder 1998, 2001; Schwalme et al. 1985). Specific river habitat information was identified from the high and low level fly-over video, recorded in fall 2002 by Alberta Environment.

Despite the relatively large number of studies, investigations have primarily concentrated on Segments 3 and 4, within the vicinity of the pulp mill and the weir, respectively. Studies of fish habitats and communities within segments 1,2 , and 5 are limited. Studies were typically seasonally focused, particularly in spring within segments 4 and 5 and fall within segments 1 and 2.

In generally, fish collections have focused on the adult life stage within the Lesser Slave River. Although some studies conducted during the spring and fall spawning periods have identified ripe fish, no efforts have been made to specifically identify spawning habitats. One study focused on capturing ripe northern pike within Segments 4 and 5 (Brilling 2000). Ripe fish were captured in backwater habitats suspected of being important spawning locations but no actual spawning sites have been identified. Longnose sucker were also collected within Segments 4 and 5 during their spawning period.

Juvenile data are limited and almost no fry information is available for the Lesser Slave River. Some tributary information exists that discusses the likely use of these streams for spawning by Lesser Slave River species; however, this information was not thoroughly examined as it was not within the scope of the present study. 
All of the fisheries studies of the Lesser Slave River were conducted during the open-water period (April though November), but as previously noted, the vast majority of data have been collected in the spring (May and June) or the fall (September and October). Almost no fisheries information is available for the summer months, and investigations of rearing, migration and overwintering activities are also limited.

\section{Lesser Slave River Fish Habitat}

Fish habitat data have been collected for the Lesser Slave River, but they are not available from the FMIS database. Much of this information was collected over ten years ago and needs to be verified for current river conditions. More recent inventory studies typically do not include habitat classification.

The Lesser Slave River provides turbid, cool-water habitat for fish. The river is narrow but generally shallow (Kellerhals et al. 1972). The majority of the upper river reaches consist of a single irregular channel of contorted meanders and numerous oxbows that have been manually cut-off from mainstem flow at the upstream end. Segment 1 in the lower section of the river has a higher gradient than the upstream segments of the river. Channel cross sections in the lower segments show typical pool depths of 2 to $3 \mathrm{~m}$, but there are pools as deep as $6 \mathrm{~m}$ in areas where channel scour has occurred due to high velocities (usually at the outside of river bends). The substrate changes from layers of deep sand or silt with small patches of bedrock and coarser substrate in the upstream segments to more abundant gravel, cobble and bouldersized substrate areas in the downstream segments (R.L.\&L 1980, AENV 2002). Instream cover is limited and provided mainly by depth and turbidity, with some cover available along specific bank types that have boulder substrate or bank material that has fallen into the channel. Riparian habitat is composed of sparsely forested lowlands and extensive muskeg with limited nearby cultivation.

Instream habitats such as riffles, runs and pools are reported as frequent throughout the length of the Lesser Slave River (Fisheries Management Division 2002). Sections of Segment 1 (defined as the region from the confluence with the Athabasca River to Driftwood River) have a 70:30 pool to riffle ratio. Downstream sections are mainly slow runs. Segment 2 (from the Driftwood River to the Saulteaux River) has a 60:40 pool to riffle ratio with several pools up to $6 \mathrm{~m}$ deep. There is a rapids near the upstream end of Segment 2. Segment 3 (from the 
Saulteaux River to the Tollenger Road Bridge) has several rapids in the downstream sections, while the remainder of the segment is composed almost entirely of a deep run ( 2 to $4 \mathrm{~m}$ deep). Segment 4 (from the Tollenger Road Bridge upstream to the weir) is almost entirely slow run habitat with oxbow snyes and deep backwaters. Segment 5 (from the weir upstream to Lesser Slave Lake) has limited habitat characterization, but it is expected to be largely ponded water behind the weir structure.

Limited bank analysis has been conducted for the Lesser Slave River. The main categories used to describe available bank habitats include slightly unstable canyon (sandstone cliffs) within Segment 1 and slightly unstable depositional (aggrading sediment) banks with a distinct valley through segments 2 to 5 .

\section{Lesser Slave River Fish Communities}

In total, 15 fish species have been documented to occur in the mainstem Lesser Slave River (Table 13), including 7 sport species, 2 sucker species and 6 small-bodied forage species. Due to a limited sampling effort in Segment 1 and the seasonal emphasis of study over the years, only five of the eight key species have been documented in this segment. Similarly, all of the key species except lake whitefish, goldeye and emerald shiner have been collected in Segment 2. Of the eight key species, only Goldeye and emerald shiner were not collected in Segment 3. Segment 4 was utilized by all eight key species, and included many northern pike in spawning condition in the spring, and lake whitefish and white sucker in the fall. Each of the key species was abundant during studies in Segment 5, for all life stages except rearing. Numerous ripe northern pike, longnose suckers and white suckers were collected in Segment 5 during the spring. A large number of fishes have been collected in Segment 5, but this is likely reflective of the sampling attention given to the effect of the weir and fishway on fish movement since 1982. 
Table 13

Fish Species Documented to be Present in the Mainstem Lesser Slave River

\begin{tabular}{|l|l|c|c|}
\hline \multicolumn{1}{|c|}{ Common Name } & \multicolumn{1}{|c|}{ Scientific Name } & $\begin{array}{c}\text { Abundance } \\
\text { Rating(a) }\end{array}$ & $\begin{array}{c}\text { River } \\
\text { Segment }\end{array}$ \\
\hline \hline Arctic grayling & Thymallus arcticus & $\mathrm{R}$ & $\mathrm{I}$ \\
\hline burbot & Lota lota & $\mathrm{R}$ & $\mathrm{I}$ \\
\hline emerald shiner & Notropis atherinoides & $\mathrm{A}, \mathrm{I}$ & 4,5 \\
\hline goldeye & Hiodon alosoides & $\mathrm{R}, \mathrm{S} ?$ & 1,5 \\
\hline lake chub & Couesius plumbeus & $\mathrm{R}$ & $\mathrm{I}$ \\
\hline lake cisco & Coregonus artedii & $\mathrm{R}$ & $\mathrm{I}$ \\
\hline lake whitefish & Coregonus clupeaformis & $\mathrm{A}$ & $3,4,5$ \\
\hline longnose sucker & Catostomus catostomus & $\mathrm{A}$ & 2,3 \\
\hline mountain whitefish & Prosopium williamsoni & $\mathrm{A}$ & $\mathrm{All}$ \\
\hline northern pike & Esox lucius & $\mathrm{A}$ & $\mathrm{All}$ \\
\hline spottail shiner & Notropis hudsonius & $\mathrm{A}, \mathrm{I}$ & $\mathrm{I}, 4,5$ \\
\hline trout-perch & Percopsis omiscomaycus & $\mathrm{R}$ & $\mathrm{I}$ \\
\hline walleye & Sander vitreus & $\mathrm{A}, \mathrm{S} ?$ & $\mathrm{All}$ \\
\hline white sucker & Catostomus commersoni & $\mathrm{A}$ & $\mathrm{All}$ \\
\hline yellow perch & Perca flavescens & $\mathrm{R}$ & $\mathrm{I}$ \\
\hline
\end{tabular}

Bold $=$ Key Species.

(a) Abundance Rating: $A$ = Abundant; typically present in large numbers during open-water period, $S=$ Seasonal; abundant in one season, otherwise uncommon, $R=$ Rare; present irregularly and in very low numbers, I = Insufficient data.

\subsubsection{Habitat Suitability Information}

Habitat suitability information has not been developed for the Lesser Slave River. It has become common practice to use expert workshop to generated this type of information; however, this approach is best applied when some site-specific data are available. Workshop curves have been developed in Alberta for the South Saskatchewan River Basin (Addley et al. 2003). Habitat suitability information developed in this workshop-type setting is available for all life stages of mountain whitefish, walleye and northern pike. The mountain whitefish suitabilities were developed based on a substantial amount of supporting data, although the data were collected from southern Alberta streams. Walleye suitability information was developed using an expert workshop but are based on a minimal amount of data from Alberta. Northern pike suitability information was developed from the Battle River using pre-positioned electrofishing. The northern pike information has not been updated during any of the recent expert workshops in Alberta. 


\subsubsection{Walleye}

Walleye is a regionally important sport species that typically occurs in large, shallow, turbid lakes and in large, turbid rivers. The walleye population of the Lesser Slave River uses the river for some or all of its life stages, but specifics are unknown. It is suspected that some or all of these life history activities also occur in Lesser Slave Lake or Athabasca River, but information is limited. The proportion of the population that completes each of these activities in the river compared to those that occur in the lake or Athabasca River is unknown.

The lack of data makes interpretation difficult for some of the life history stages. The relationship between walleye in the Lesser Slave River, Athabasca River and Lesser Slave Lake is unknown. There potential exists that they are all belong to the same population and use the different waterbodies to carry out specific life history requirements. Alternatively, there may be more than one population of walleye with a resident population that carries out all of the life history stages in the Lesser Slave River. The data available for this review was inconclusive in this regard.

\section{Spawning}

Spawning activity occurs in the spring, shortly after ice break-up, in areas with rocky substrate and either turbulent flow (rivers) or high wind action (lakes). It is suspected that spawning takes place in Lesser Slave Lake and within Segments 2 and 3 of the river; however river spawning by this species has not been confirmed.

The major spawning areas for walleye in Lesser Slave Lake are at the west end of the lake (include Buffalo Bay and South Heart River). Walleye leave the east end of the lake in early spring, in response to the shallower, warmer water conditions at the west end. Walleye spawned in the first two weeks of May in the South Heart River and Buffalo Bay at the west end of Lesser Slave Lake in 1983 (O'Neil 1983). This would suggest that any ripe fish located in the river during the spring are likely not using the lake for spawning since in the east portion of the lake is not a common spawning location. Monitoring of the fishway has also shown that walleye make very limited use of the fishway; therefore, any fish present in the Lesser Slave River in the spring are likely spawning in the river rather than moving upstream into the lake. 
The upper segments of the Lesser Slave River would largely be unsuitable for spawning due to the sand/silt substrate and the slow run habitat. There may be potential walleye spawning habitat immediately below the weir due to the availability of faster water and coarse substrate. The most likely location for walleye spawning would be in the middle and lower reaches of the river where conditions are best-suited for spawning use (i.e., riffle/run habitats and coarse substrate).

Walleye spawning data from FMIS is very limited; however, a spent female and a ripe (spent?) male were caught below weir on May 10, 2000. These fish may have spawned in the river and moved to the weir for feeding, or they may have spawned below the weir. The lack of understanding of the life cycle and movement patterns of walleye in the Lesser Slave system makes interpretation of the data difficult.

\section{Nursery (Fry)}

Based on FMIS data and a document search at Alberta Environment, information on the fry (young-of-the-year) life stage and nursery habitat of the Lesser Slave River is lacking and requires further study. Based on the potential for spawning habitat in the lower segments of the river, sampling for fry should be focused downstream of the Saulteaux River on the mainstem and within the Saulteaux and Driftwood rivers, since tributary spawning is another possibility within the Lesser Slave River system.

\section{Rearing (Juvenile)}

Based on FMIS data and a document search at Alberta Environment, information on the walleye rearing life stage and juvenile habitat of the Lesser Slave River is lacking and requires further study.

\section{Feeding (Adult)}

Walleye feed mostly on fish and aquatic invertebrates, with larger individuals being primarily piscivorous. Because walleye vision is adapted to dark, turbid conditions, this species is sensitive to light and, as a result, cover is an important aspect of suitable walleye habitat. Submerged cover, turbidity and thick layers of ice may all act as overhead cover and shield walleye from bright sunlight. 
Based on FMIS data and a document search at Alberta Environment, information on the adult walleye life stage and feeding habitat in the Lesser Slave River is limited. Adult walleye have been captured in limited numbers within each of the sections. Details on habitat use are also limited but suggest an affinity for the deeper pools within the segments.

The availability of prey species would be high in the Lesser Slave River due to the large numbers of emerald shiners, spottail shiners and other forage species found in the river. Feeding conditions are probably ideal below the weir because of good holding water and an abundance of prey.

\section{Overwintering}

Based on FMIS data and a document search at Alberta Environment, information on overwintering use of the Lesser Slave River is limited and requires further study. Adult walleye have been collected from the Lesser Slave River during early October. This suggests that they may overwinter in the system, although there is also the possibility that they move out later in the fall.

Within the Lesser Slave River system, there are essentially three options for overwintering by walleye; within the river itself, moving upstream to the lake, or, moving downstream to the Athabasca River. If the fishway is functional in the fall then they move upstream to the lake; however, walleye have not been found to utilize the fishway in the two monitoring studies (although neither were conducted in the fall). Walleye inhabiting Segments 1 through 3 in the late fall may move to the Athabasca River to overwinter, although there are some deep pools present in the lower reaches of Segment 1 that may provide suitable overwintering habitat. NRBS (1994b) determined that adult walleye (as well as fry and juveniles) were well represented in the catch in the sample sections upstream and downstream of the Lesser Slave River confluence during fall sampling (October 19-21, 1993). This suggests that some walleye overwintering occurs in this region of the Athabasca River.

\section{Migration}

It is not known what interaction, if any, there is between walleye found in Lesser Slave Lake and the walleye found in the river. Walleye typically exhibit spring spawning migrations, often under 
ice-cover, to suitable spawning locations. Both fishway monitoring studies have found very limited use of the fishway by walleye suggesting that migration to the lake may be minimal. There possibility exists that walleye move over the weir during high flow conditions, but this has not been documented. There is also the possibility that walleye migrate into the Lesser Slave River from the Athabasca River in the spring to spawn. The relationship between walleye in the Athabasca River and Lesser Slave River is unknown.

\subsubsection{Northern Pike}

Northern pike are found in lakes and marshes and, although they prefer heavily vegetated, shallow, clear waterbodies, they can also be found in streams and rivers with slow to moderate current. Adult northern pike have been captured mostly within Segment 3, 4 and 5 of the river, with many ripe adults captured immediately downstream and upstream of the weir. Northern pike are suspected to spawn, rear and feed within the oxbows and bays of Segment 4; however, no studies have focused on confirming this possibility. Additional surveys suggest northern pike utilize Segment 1 for rearing (EVS 1990).

The Lesser Slave River population of northern pike is suspected to use the Lesser Slave River and its tributaries for all of its life history requirements. Spring studies have shown that northern pike are most abundant in the upstream segments of the river, frequently captured in oxbows and bays during the spring spawning season. The monitoring studies conducted for the fishway have found large numbers of northern pike using the fishway, indicating movement between the lake and the river is occurring. The most recent study also sampled fish below the fishway and concluded that the fish using the fishway were significantly smaller than the fish downstream of the fishway (Eco-Logic 2000).

\section{Spawning}

Spawning site preference for northern pike is more related to adequate vegetation than to substrate type and they have been reported to use submergent, emergent and flooded vegetation over a variety of substrate materials (Nelson and Paetz 1992, Scott and Crossman 1973). Large numbers of mature northern pike (ripe, spent) have been captured upstream and downstream of the weir in segments 4 and 5, although spawning habitat was not assessed directly (Brilling 2000). 
Golder (2003) captured large numbers of recently hatched pike fry in the extensive backwater upstream of the weir. Sampling occurred during spring 2003 as part of the construction monitoring for the new Highway 88 Bridge. This provides confirmation of spawning in the immediate area.

It is also suspected that northern pike spawning would occur in tributary systems to the Lesser Slave River. Very limited tributary information on northern pike was available from FMIS and no conclusions regarding spawning use of these tributaries can be made at this time.

\section{Nursery (Fry)}

Northern pike are suspected to spawn, rear and feed within the oxbows and bays of Segment 4; however, no studies have focused on confirming this suspicion. Based on FMIS data and a document search at Alberta Environment, the fry life stage and use of nursery habitat in the Lesser Slave River is limited, and requires further study. The only documented use of the river by fry occurred in Segment 5 .

\section{Rearing (Juvenile)}

Some rearing of juvenile northern pike is likely to occur in tributary watercourses, and the Lesser Slave River mainstem also provides rearing habitat for juvenile fish, particularly in tributary confluence areas. Young fish are frequently captured in Segment 1 near the confluence of the Athabasca River and it is suspected these downstream areas are important rearing habitat (EVS 1990). Juvenile northern pike have also been collected within each river segment below the weir and it is suspected that all segments provide juvenile rearing habitat.

\section{Feeding (Adult)}

The northern pike diet is largely made up of fish, crustaceans, insects and small aquatic animals. In Lesser Slave Lake and the Lesser Slave River species such as spottail shiner and emerald shiner are known to be major food items. Adult northern pike were captured mostly within the three upstream segments of the river, with many ripe adults captured at the weir and within the middle section of Segment 4. Since northern pike have been observed using the fishway, the use of the lake versus the river by northern pike for feeding is not known. 


\section{Overwintering}

Based on FMIS data and a document search at Alberta Environment, information on overwintering habitat of the Lesser Slave River is limited and requires further study. Overwintering activity is suspected to occur in Lesser Slave Lake, although recent telemetry results from the Athabasca River indicate northern pike will use relatively shallow, slow water within riverine ecosystems for overwintering and exhibited very little movement from summer feeding habitat locations (R.L.\&L./Golder 2003). The efficiency of the fishway has not been monitored during the fall and it is unknown if northern pike can or do move from the river to the lake to overwinter.

\section{Migration}

The Lesser Slave River is an important migration route for northern pike moving to and from Lesser Slave Lake, and possibly for fish originating from the Athabasca River. Extensive movements between the lake and the river were verified during studies to determine the effectiveness of the fishway facility situated at the weir (Schwalme et al. 1984, Eco-Logic 2000). Both of these studies were conducted during the spring and it is not known if a fall migration to overwintering habitat occurs.

\subsubsection{Lake Whitefish}

Lake whitefish is an important sport, commercial and subsistence fish. Lake whitefish generally inhabit cool, well-oxygenated regions of lakes, but also occur in large rivers. The lake whitefish population in the Lesser Slave River is assumed to be associated with Lesser Slave Lake, but it is unknown if they use the Lesser Slave River for all of their life history requirements. Lake whitefish are abundant within the three upstream segments of the river, specifically upstream of the pulp mill outfall in Segment 3.

The relationship between a lake whitefish population in Lesser Slave Lake and a potential population that uses the river is unknown. During the fall spawning and migration period, lake whitefish are abundant in sections of Segment 3 of the Lesser Slave River, upstream of the pulp mill outflow. While it is likely the Lesser Slave River is mainly used as a migratory route and spawning area in the fall, as well as for resting and feeding by migrating fish, there is limited 
documentation in support of this theory. No studies were found that documented rearing, feeding or overwintering activity by lake whitefish in the Lesser Slave River.

\section{Spawning}

Lake whitefish spawn in the fall; preferred spawning habitat is described as boulder, cobble and gravel sized substrate most commonly in lakes (Nelson and Paetz 1992, Scott and Crossman 1973). Lake whitefish spawning occurs extensively within Lesser Slave Lake, but based on numbers captured in Segment 3 of the Lesser Slave River in the fall, some fish from the Lesser Slave Lake population may spawn in the Lesser Slave River (EVS 1990). Since no spawning activity has been confirmed within the mainstem, it may be possible that the lake whitefish sampled in the fall (late September) were caught prior to a migration upstream to the lake to spawn. Confirmation of lake whitefish spawning movements within the mainstem of the Lesser Slave River would require additional study.

\section{Nursery (Fry)}

Based on FMIS data and a document search at Alberta Environment, information on the fry life stage and nursery habitat of the Lesser Slave River is limited and requires further study.

\section{Rearing (Juvenile)}

Based on FMIS data and a document search at Alberta Environment, information on the rearing life stage and juvenile habitat of the Lesser Slave River is limited and requires further study.

\section{Feeding (Adult)}

Lake whitefish feed primarily on bottom organisms such as chironomid larvae, clams, snails, amphipods, other insect larvae and zooplankton. Lake whitefish have been sampled in the mainstem Lesser Slave River from May through October, suggesting that some seasonal feeding is occurring in this river. Almost all of the lake whitefish sampled in the mainstem have been adults and were most abundant in Segments 3 and 4. 


\section{Overwintering}

Based on supplied FMIS data and a document search at Alberta Environment, overwintering habitat of the Lesser Slave River is limited and requires further study. It is assumed most lake whitefish would use the lake for overwintering.

\section{Migration}

Lake whitefish are captured primarily within the upper three segments of the river; therefore, the migratory behaviour is speculatively limited to the upper half of the river. Lake whitefish were not present in the catch in the mainstem Athabasca River in sample sections located upstream and downstream of the Lesser Slave River confluence (NRBS 1994a, 1994b). This suggests that lake whitefish in the Lesser Slave River are associated with Lesser Slave Lake. Lake whitefish are known to ascend the fishway situated near the outlet of Lesser Slave Lake (Schwalme et al. 1984, Eco-Logic 2000).

\subsubsection{Mountain Whitefish}

Mountain whitefish occur in rivers and lakes in western Alberta, including the Milk River, the North and South Saskatchewan rivers, and the upper Peace and Athabasca rivers (Nelson and Paetz 1992; Scott and Crossman 1973). Mountain whitefish habitat is typically clear, cold rivers with water temperatures between 8 and $14^{\circ} \mathrm{C}$ and shallow portions of lakes (Nelson and Paetz 1992, Ford et al. 1995).

Mountain whitefish are abundant and widespread in the Athabasca River mainstem from Jasper National Park downstream to below the confluence of the Lesser Slave River (NRBS 1994b). Within the Lesser Slave River, mountain whitefish are most abundant within the cooler, faster habitats of segments 1 and 2 with very few individuals captured upstream of Segment 3 . The abundance of mountain whitefish in the lower reaches of the Lesser Slave River might indicate a connection with the Athabasca River population. 


\section{Spawning}

Mountain whitefish spawning occurs from late September to early November over gravel shallows in lakes or most commonly over gravel in streams (Nelson and Paetz 1992). Water temperatures are usually between 0 and $12^{\circ} \mathrm{C}$ during egg development in waters with some velocity (Ford et al. 1995). No nest is built and the eggs are deposited on the substrate at depths of 0.1 to $1.0 \mathrm{~m}$ (Ford et al. 1995). Spawning is uncommon at depths $>5 \mathrm{~m}$; however, pelagic spawning has been observed by Hagen (1970).

Earlier studies suspected that mountain whitefish spawning occurred outside of the Lesser Slave River system because no ripe or sexually mature fish had been captured in the tributaries or mainstem of the Lesser Slave River (EVS 1990). However, recent inventory data shows two locations that held adult mountain whitefish in pre-spawning and spent condition (including females) in late September and early October. The predominant area where the individuals were captured was in Segment 3 downstream of the Otauwau River and about $5 \mathrm{~km}$ upstream of the confluence with the Athabasca River. Abundant adult mountain whitefish have also been captured throughout Segment 1 and Segment 2 in late September and October, although spawning conditions was not noted.

NRBS (1994b) boat electrofishing work done in the fall of 1993 (downstream of the Lesser Slave River confluence) determined that mountain whitefish were abundant ( $80 \%$ of the catch). Sampling conducted on October 20 and 21, 1993 found large concentrations of adults (many in spawning condition), suggesting that the area was used for spawning. It is possible that the mountain whitefish in the Lesser Slave River are part of the Athabasca River population, although the area around in Segment 3 may well be a spawning site of a resident population.

\section{Nursery (Fry)}

Mountain whitefish eggs hatch between March and late April when ice breakup occurs on the rivers (Nelson and Paetz 1992). NRBS (1995) determined that mountain whitefish in the Athabasca River emerged from gravel from early April to early May depending on the section of river involved. 
Based on FMIS data and a document search at Alberta Environment, information on use of the Lesser Slave River for fry rearing was not available and requires further study.

\section{Rearing (Juvenile)}

Juvenile mountain whitefish were common downstream of the Otauwau River within Segment 3, with the highest abundance in segments 1 and 2 of the Lesser Slave River. Some juvenile fish have been collected above Segment 3, although it is not likely to be a major rearing location due to the relatively poor habitat conditions for this life stage. Juvenile fish were present in the Lesser Slave River in May and October, but summer sampling was not conducted.

\section{Feeding (Adult)}

Mountain whitefish feed largely on bottom fauna (Nelson and Paetz 1992) at depths less than $3 \mathrm{~m}$ over gravel or cobble substrates (Ford et al. 1995). In the Lesser Slave River, mountain whitefish are suspected of using the lower segments of the river for feeding (EVS 1990).

A majority of adult mountain whitefish were collected downstream of the Otauwau River in Segment 3. Some adult fish have been collected above Segment 3, although it is not suspected to be a major feeding location due to the habitat conditions of the upper segments. Adult fish were present in May and September through October, but summer sampling was not conducted.

\section{Overwintering}

Based on FMIS data and a document search at Alberta Environment, information on overwintering use of the Lesser Slave River is limited and requires further study. Mountain whitefish have been captured in late fall (October 15) and early spring (May 15) in the Lesser Slave River, which may suggest overwintering is occurring. However, the Athabasca River would also provide suitable overwintering conditions for this species. Confirmation of overwintering use of the Lesser Slave River is required.

\section{Migration}

The majority of mountain whitefish populations exhibit relatively consistent migration patterns to different areas for spring and summer feeding, spawning, and overwintering (Nelson and Paetz 
1992). Within the Lesser Slave River, mountain whitefish are most abundant within segments 1 and 2 with very few individuals captured upstream of Segment 3. Mountain whitefish may migrate to the Athabasca River to overwinter and return to the Lesser Slave River in the spring to feed and remain until spawning. Due to the abundance of spawning mountain whitefish in the Athabasca River in the vicinity of the Lesser Slave River, there is also a possibility that some fish migrate out of the Lesser Slave River in the fall to spawn. Based on FMIS data and a document search at Alberta Environment, the migratory behaviour of mountain whitefish in the Lesser Slave River is speculative and requires further study.

\subsubsection{Goldeye}

Goldeye typically inhabit large rivers with high turbidity and small lakes, ponds and marshes connected to them. The muddy shallows of large lakes are also provide ideal habitat for this species. Goldeye are known to occupy the Athabasca River both upstream and downstream of the Lesser Slave River confluence (NRBS 1994b and 1995).

Goldeye vision and spawning biology is well adapted to life in turbid waters. In general, their diet consists of zooplankton and aquatic and terrestrial insects. Goldeye also feed on other fish and aquatic animals such as shrews and amphibians, with diet reflecting the size of the fish.

The goldeye information for the Lesser Slave River is very limited. Goldeye have been captured in three separate studies (in segments 1 and 5), with the most abundant numbers captured during one summer sample conducted in 1979 (R.L.\&L. 1980). Angler catch reports from the Lesser Slave River indicate that adult goldeye are present in the summer (D. DeRosa, pers. comm.), and it is suspected that the spring and fall focus of previous fisheries studies may have overlooked the importance of the Lesser Slave River for summer feeding by goldeye. Based on the FMIS data and document reviews, there have been few studies to account for the other life stage activities and status of the goldeye population in the Lesser Slave River.

\section{Spawning}

Spawning occurs in the spring and spawning habitat for this species is generally reported as muddy, turbid rivers or backwater ponds and lakes connected to rivers. The fertilized eggs are semi-buoyant so that incubation is completed in the water column rather than on the silty bottom. 
Based on the FMIS data and document reviews, there have been few studies to account for the activities and status of the goldeye population in the Lesser Slave River and no spawning information is known to exist at this time.

NRBS (1994a) noted presence of goldeye in pre-spawning condition (May 2, 1992) in Athabasca

River mainstem near the confluence of the Lesser Slave River. They speculated that spawning likely occurred in the mainstem near the capture site or in a nearby tributary such as the Lesser Slave River.

\section{Nursery (Fry)}

Based on the FMIS data and document reviews, there have been few studies to account for the activities and status of the goldeye population in the Lesser Slave River and no fry life stage or nursery habitat information is known to exist at this time.

\section{Rearing (Juvenile)}

Based on the FMIS data and document reviews, there have been few studies to account for the activities and status of the goldeye population in the Lesser Slave River and no rearing life stage or juvenile habitat information is known to exist at this time.

\section{Feeding (Adult)}

Angler catch reports of goldeye in the vicinity of the weir indicate that goldeye are using the Lesser Slave River during the summer months (D. DeRosa, pers. comm.). The timing when goldeye enter and leave the Lesser Slave River system is not known. The abundance of goldeye in the Lesser Slave River cannot be determined as no studies have focussed on summer goldeye sampling.

\section{Overwintering}

Based on the FMIS data and document reviews, there have been few studies to account for the activities and status of the goldeye population in the Lesser Slave River (DeRosa, D. personal communication) and no goldeye overwintering habitat information for the Lesser Slave River is known to exist at this time. 


\section{Migration}

From the limited data available, it would appear that goldeye are using the Lesser Slave River on a seasonal basis, possibly migrating into the system after spring and leaving prior to fall. The captures of goldeye have been located near the Athabasca River, around the confluence of the Driftwood River and at the weir. Fish were taken in mid-May and in the fall at the lower and Driftwood sites, and in mid-June below the weir. The limited catch of goldeye from previous spring and fall sampling and angler catch in the summer would suggest that a summer postspawning feeding migration may occur. It is not known if the suspected post-spawning migration is originating from one of the two lower sites on the Lesser Slaver River or from the Athabasca River.

\subsubsection{Longnose Sucker}

The habitat of the adult longnose sucker in deep lakes is generally depths $>10 \mathrm{~m}$, and they are most abundant in cold $\left(10\right.$ to $\left.15^{\circ} \mathrm{C}\right)$ oligotrophic lakes. They have a high affinity for cover and vegetated areas associated with gravel, sand, and detritus substrates (Langhorne et al. 2001).

Within the Lesser Slave River, longnose sucker are abundant within the middle sections of the river (segments 2 and 3), particularly downstream of the Otauwau River inlet; however, they have been captured throughout the mainstem river.

\section{Spawning}

Longnose sucker move to tributary streams to spawn when temperatures exceed $5^{\circ} \mathrm{C}$ or shortly after ice-out in mid-April to mid-May (Langhorne et al. 2001). Spawning depths are reported as up to $1 \mathrm{~m}$ (Scott and Crossman 1973). They may also spawn in shallow regions of lakes on wave-swept shores at depths between 15 and $30 \mathrm{~cm}$ (Nelson and Paetz 1992; Scott and Crossman 1973; Langhorne et al. 2001). Spawning takes place in riffles over gravel, cobble, or rubble substrates, and rarely over sand (Nelson and Paetz 1992; Scott and Crossman 1973; Langhorne et al. 2001). The eggs are deposited over the substrate, fall to the substrate and adhere.

Within the Lesser Slave River watershed, it is suspected that the tributaries are important longnose sucker spawning habitat (EVS 1990). Limited data available from FMIS indicate 
longnose sucker are present in the Otauwau and Driftwood rivers in June; however, this information has not been reviewed in detail. Abundant mature longnose suckers, in both ripe and spent condition, have been sampled in the spring within Segment 4 in the vicinity of the weir suggesting spawning occurs over suitable substrate downstream of the weir. Most of the individuals were still ripe in early May and by the end of May into early June, most individuals were spent. This would suggest spawning on the Lesser Slave River continues until approximately mid-May. Spawning information for the lower segments was not available.

\section{Nursery (Fry)}

The newly hatched young remain in the gravel for one to two weeks, and when spawned in rivers, remain for most of their first summer at water depths of approximately $15 \mathrm{~cm}$ and then drift into lakes (Langhorne et al. 2001). Fry are found in shallow, quiet waters with submergent and emergent vegetation cover, and around boulders, rubble, and gravel in depths up to $1 \mathrm{~m}$ (Langhorne et al. 2001).

Within the Lesser Slave River, studies indicate that the tributaries are important longnose sucker spawning habitat (EVS 1990); however, this information has not been reviewed. Longnose sucker fry $(<50 \mathrm{~mm})$ were collected in September within Segment 3. No other information was available on fry rearing habitats and additional sampling would be required to identify fry rearing locations within the other segments of the river.

\section{Rearing (Juvenile)}

Juvenile habitat consists of shallow, vegetated areas of lakes similar to nursery habitat, with depths $<5 \mathrm{~m}$, and with some current on the surface. As they grow older, longnose sucker change from a planktivorous feeder to a benthic feeder and are known to ingest plants, algae and detritus (Langhorne et al. 2001).

Juvenile longnose suckers have been captured in all reaches of the Lesser Slave River. Yearling longnose suckers $(<100 \mathrm{~mm})$ have been capture within segments 3,4 and 5 while larger juvenile fish have been capture in modest numbers and appear more common within Segment 1 and 2 and below the Otauwau River in Segment 3. 


\section{Feeding (Adult)}

All segments have provide adult longnose sucker habitat. Although the sampling has been seasonal, adults are present in the Lesser Slave River in May and June as well as in September and October. The spring sampling was concentrated to Segment 4 directly below the weir and abundant adult longnose sucker were captured. Fall sampling in Segments 1, 2 and 3 have also found abundant adult longnose sucker. Summer sampling has not been conducted and locations of habitat use during the summer months are not known.

\section{Overwintering}

Based on FMIS data and a document search at Alberta Environment, overwintering habitat data for longnose sucker in the Lesser Slave River are limited and requires further study.

\section{Migration}

Longnose sucker are captured in greatest abundance within the middle segments of the river; however, they were captured throughout the river in most studies. The migratory behaviour of longnose sucker is speculative, but studies have shown they do ascend the fishway to pass the weir (Schwalme et al. 1984, Eco-Logic 2000).

Based on FMIS data and a document search at Alberta Environment, data on migratory patterns of longnose sucker in Lesser Slave River are limited and requires further study

\subsubsection{White Sucker}

White sucker occur throughout Alberta but do not extend into the Rocky Mountains (Nelson and Paetz 1992). Within the Lesser Slave River, white sucker are frequently captured in the upstream sections of Segment 3 but are most abundant within the river system from Segments 3 to 5 (EVS 1990).

\section{Spawning}

White sucker mature at the age of 5 or 6 years and they travel to tributary streams or beaches of lakes (specifically in Alberta) to spawn. Spawning occurs from mid-May to early July, when 
water temperatures are approximately $10^{\circ} \mathrm{C}$ (Nelson and Paetz 1992). The spawning sites on some streams are reported to have areas of gravel, sand, and decaying vegetation (Durbin and Fernet 1979). Spawning occurs in shallow ( $<1 \mathrm{~m})$, gravel riffle sections of streams, rapids, and less frequently along lake margins that have substrates of gravel, sand, silt and clay (Nelson and Paetz 1992; Langhorne 2001). Spawning cover consists of emergent vegetation. Eggs are released into the water and either adhere to the substrate in the spawning area or drift downstream (Langhorne 2001).

Within the Lesser Slave River, studies suspect that the tributaries are important white sucker spawning habitat (EVS 1990) however this information has not been reviewed. Recent inventory data have found abundant mature fish in ripe and spent conditions immediately upstream and downstream of the weir (Segments 4 and 5) during May and early June. By mid to late June, most of the fish sampled were spent suggesting spawning likely persists until early June. No data is available for other segments.

\section{Nursery (Fry)}

Fry hatch in approximately two weeks (Scott and Crossman 1973) and fry begin their migration back to the lakes (downstream) one month after spawning occurs (Langhorne 2001). Based on supplied FMIS data and a document search at Alberta Environment, the fry (young of year) life stage and nursery habitat data for the Lesser Slave River is limited and requires further study.

\section{Rearing (Juvenile)}

Juveniles prefer depths $<5 \mathrm{~m}$ and are occasionally found between 5 and $10 \mathrm{~m}$ (Durbin and Fernet 1979; Nelson and Paetz 1992; Langhorne 2001). Juveniles frequently occur over rubble, cobble, sand, and silt-clay substrates, as well as over detritus, and in the pelagic zone (Langhorne 2001). Juveniles and adults are found associated with the cover of emergent vegetation, but are also found in areas with no cover.

The data for juvenile white suckers is very limited with a few individuals captured upstream and downstream of the weir in Segments 4 and 5. Based on supplied FMIS data and a document search at Alberta Environment, the rearing life stage and juvenile habitat data for the Lesser Slave River are limited and requires further study. 


\section{Feeding (Adult)}

White sucker are known to inhabit warmer shallow waters (Scott and Crossman 1973). They are found on the bottom of rivers in water $<5 \mathrm{~m}$ deep, and in shallow and deep lakes at approximately 5 to $15 \mathrm{~m}$ of depth (Durbin and Fernet 1979; Langhorne 2001). They are highly associated with in-situ cover including large woody debris and shady sections of streams (Langhorne 2001). Their substrate associations are reported as rubble, sand, and silt-clay (Langhorne 2001). White sucker are moderately active during the day and near sunrise and sunset they increase activity levels and move into shallower water (Scott and Crossman 1973).

Adult white suckers have been sampled in all of the segments of the Lesser Slave River. The most abundant numbers have been recorded in Segments 4 and 5. Adult fish have been sampled in May and June as well as in September and October. Summer sampling is lacking and requires further study.

\section{Overwintering}

Based on supplied FMIS data and a document search at Alberta Environment, overwintering habitat of the Lesser Slave River is limited and requires further study. Adult fish have been sampled in the mainstem river as early as May 3 and as late as October 15 suggesting the potential for overwintering to occur within the Lesser Slave River.

\section{Migration}

White sucker are captured in greatest abundance in the upper segments of the river; however, they were captured throughout the river in most studies. Studies have shown they do ascend the vertical slot and Denil fishway to pass the weir (Schwalme 1984, Eco-Logic 2000) although the movement patterns between the lake and the river have not been documented.

Based on supplied FMIS data and a document search at Alberta Environment, the adult life stage and feeding habitat of the Lesser Slave River is limited and requires further study. 


\subsubsection{Emerald Shiner}

Emerald shiner are found in all the major rivers in Alberta and Saskatchewan, including the Athabasca, Peace, Beaver, North and South Saskatchewan, Bow, Red Deer, Oldman, Petitot, Milk, Churchill, and Qu'Appelle rivers (Atton 1983; Nelson and Paetz 1992). Emerald shiner are also found in Lake Athabasca, Bistcho Lake, and Lesser Slave Lake (Nelson and Paetz 1992). Emerald shiners are widely distributed and abundant in the mainstem Athabasca River, upstream and downstream of the Lesser Slave River confluence (NRBS, 1994a, 1994b, 1995).

Abundant emerald shiners have been found upstream and downstream of the weir during the most recent fishway monitoring study. Records of emerald shiner are not available from any of the previous reports or studies.

\section{Spawning}

Sexual maturity is reached in its second year. Emerald shiner are reported to spawn in the months of June to August, at temperatures around $24^{\circ} \mathrm{C}$ (Scott and Crossman 1973), and near the surface over either shallow or deep water (Brown 1971). Spawning also occurs over a wide range of substrate types (Lane et al. 1996).

Spawning information for emerald shiner in the Lesser Slave River is non-existent and requires further attention.

\section{Nursery (Fry)}

Based on supplied FMIS data and a document search at Alberta Environment, information on the availability and use of the Lesser Slave River for fry (young of year) life stage and nursery habitat limited; this aspect requires further study.

\section{Rearing (Juvenile)}

Based on supplied FMIS data and a document search at Alberta Environment, information on the rearing life stage and juvenile habitat use of the Lesser Slave River is limited and requires further study. 


\section{Feeding (Adult)}

Based on supplied FMIS data and a document search at Alberta Environment, information on the adult life stage and habitat use of the Lesser Slave River is limited and requires further study.

\section{Overwintering}

Based on supplied FMIS data and a document search at Alberta Environment, the extent of use of the Lesser Slave River for overwintering is unknown; this aspect requires further study.

\section{Migration}

The most recent study monitoring the fishway found thousands of emerald shiner congregated below the weir. Emerald shiners were found to ascend the weir; however, the size of fish caught in the fishway was significantly larger than the fish sampled immediately downstream of the weir (Eco-Logic 2000). Preliminary evidence suggests the weir may be a barrier to juvenile emerald shiners. Seasonal movement patterns in the other segments of the Lesser Slave River are unknown.

\subsubsection{Summary}

\section{Lesser Slave River Fish Community}

Numerous fish habitat and fish community inventories have been conducted for the Lesser Slave River and its tributary watercourses. Past investigations have largely concentrated on Segments 3 and 4 , located within the vicinity of the pulp mill and downstream of the weir, respectively. Studies of fish habitats and communities within Segments 1, 2, and 5 have been conducted to a more limited extent. Each study was typically seasonally focused, particularly for spring data in Segment 5 and fall data in Segments 1 and 2. Summer inventory data is completely lacking.

In total, 15 fish species have been documented to occur in the mainstem Lesser Slave River (Table 13), including 7 sport species, 2 sucker species and 6 small-bodied forage species. Inventory studies provide some data conclusive information to categorize segment use of each fish species known to inhabit the Lesser Slave River. 


\section{Key Fish Species}

In Segment 1, only 5 of the 8 key species have been documented. All of the key species except lake whitefish, goldeye and emerald shiner where sampled in Segment 2. Goldeye and emerald shiner were the only 2 of the 8 key species not sampled in segment 3 . Segment 4 was utilized by all 8 species and included many spawning mature northern pike in spring, lake whitefish and white sucker in the fall. Each of the key species were abundant and common during studies in Segment 5 for all life stages except rearing. Numerous spawning mature northern pike, longnose suckers and white suckers were sampled during the spring. There was a large abundance of fish sampled in Segment 5, however this may be reflective of the sampling attention given to the effect of the weir and fish way on fish movement since installation in 1982.

\section{Data Gaps}

Overwintering of key species needs further study, although it is assumed many individuals may move to either the lake or to the Athabasca River to overwinter. No studies have are available to confirm overwintering movements or identify overwintering habitats within the Lesser Slave River. The presence of deep holes in Segment 1 may provide potential for overwintering, but this has not been investigated. The presence of thermal refugia from groundwater inputs may also provide suitable overwintering locations, although no information was found to identify potential thermal refugia in the Lesser Slave River.

Migration information is limited to the fishway studies conducted in 1984 and again in 2000. Both studies were conducted in the spring and therefore summer and fall movements past the weir have not been documented. Some of the monitoring data suggests that the fishway is not being used by some of the larger northern pike or by the smaller size ranges of emerald shiner. It does not appear that walleye or goldeye use the fishway to any degree. From the dataset, it is impossible to definitively conclude movement efforts.

Spawning locations can not be concluded for any of the key species from the available data. The abundance of ripe or spent northern pike in the spring throughout Segments 4 and 5 provides a strong indication that spawning is occurring in the mainstem, likely in the oxbows and backwaters. Spawning has been confirmed at one location in Segment 5 upstream of the weir. It is suspected that northern pike would also use tributaries for spawning although this has not been 
well documented. A few ripe walleye have been found in the mainstem of the Lesser Slave River, although it is suspected that spawning may occur in the tributary watercourses. Mature mountain whitefish have been found in the Lesser Slave River in the fall and are thought to spawn in the mainstem, although presence of eggs has not been documented and larval fry have not been collected to confirm this suspicion. Although lake whitefish have been found in the fall within the mainstem, it is suspected that most spawning occurs in the lake. Ripe white and longnose suckers have also been sampled within the mainstem which would also indicate mainstem spawning is occurring. The presence of longnose sucker fry further suggest that spawning is occurring in the mainstem.

There is also a paucity of fry data available for the Lesser Slave River. Fry data would not only help confirm mainstem spawning, but it may also be a critical life stage for some species depending on the habitat requirements.

There is a lack of summer inventory data for the Lesser Slave River. Goldeye appear in very low numbers in the spring and fall samples; but are expected to be more numerous in the winter. Information on seasonal fish distribution within the Lesser Slave River is required to develop accurate species periodicity table for use in the IFN evaluation.

Once some of the basic biological questions have been answered, site-specific habitat use data will be required for the IFN evaluation. Habitat data necessary for developing habitat suitability criteria (HSC) have not been collected as a component of previous sampling efforts. Application of HSC would be specific to the seasonal timing of each different species and life stage found in each segment. Preliminary species periodicity tables for each segment are provided in Tables 14-18. Data gaps that remain in defining the distribution and timing of fish within the Lesser Slave River should be addressed by additional field inventory studies, by conducting an expert workshop or both. 
Table 14

Summary of Timing and Distribution for Fish Species Segment 1

\begin{tabular}{|c|c|c|c|c|c|c|c|c|c|c|c|c|c|}
\hline \multirow[t]{2}{*}{ Species } & \multirow{2}{*}{$\begin{array}{c}\text { Life History } \\
\text { Stage/Activity }\end{array}$} & \multicolumn{12}{|c|}{ Month } \\
\hline & & $\mathbf{J}$ & $F$ & $M$ & A & $\bar{M}$ & $J$ & $\mathbf{J}$ & A & $\mathbf{s}$ & 0 & $\mathbf{N}$ & D \\
\hline \multirow[t]{6}{*}{ Walleye } & Fry/Nursery & \multicolumn{12}{|c|}{ No Data } \\
\hline & Juvenile/Rearing & & & & & $?$ & $?$ & $?$ & $?$ & $P$ & $P$ & & \\
\hline & Adult/Feeding & & & & & $?$ & $?$ & $?$ & $?$ & $P$ & $P$ & & \\
\hline & Adult/Spawning & & & & & NS & NS & & & & & & \\
\hline & Overwintering & \multicolumn{12}{|c|}{ No Data } \\
\hline & Migration & & & & & NS & NS & NS & NS & NS & NS & & \\
\hline \multirow[t]{6}{*}{ Northern pike } & Fry/Nursery & \multicolumn{12}{|c|}{ No Data } \\
\hline & Juvenile/Rearing & & & & & $A$ & $\bar{A}$ & $\bar{A}$ & A & $A$ & $A$ & & \\
\hline & Adult/Feeding & & & & & $\mathrm{A}$ & $A$ & $\bar{A}$ & $\bar{A}$ & $\bar{A}$ & $\bar{A}$ & & \\
\hline & Adult/Spawning & & & & & NS & NS & & & & & & \\
\hline & Overwintering & \multicolumn{12}{|c|}{ No Data } \\
\hline & Migration & & & & & NS & NS & NS & NS & NS & NS & & \\
\hline \multirow[t]{6}{*}{ Lake whitefish } & Fry/Nursery & \multicolumn{12}{|c|}{ No Data } \\
\hline & Juvenile/Rearing & & & & & NS & NS & NS & NS & NS & NS & & \\
\hline & Adult/Feeding & & & & & NS & NS & NS & NS & NS & NS & & \\
\hline & Adult/Spawning & & & & & & & & & NS & NS & & \\
\hline & Overwintering & \multicolumn{12}{|c|}{ No Data } \\
\hline & Migration & & & & & NS & NS & NS & NS & NS & NS & & \\
\hline \multirow[t]{6}{*}{ Mountain whitefish } & Fry/Nursery & \multicolumn{12}{|c|}{ No Data } \\
\hline & Juvenile/Rearing & & & & & $A$ & $\mathrm{~A}$ & $?$ & $?$ & $P$ & $P$ & & \\
\hline & Adult/Feeding & & & & & $P$ & $A$ & $?$ & $?$ & $P$ & $P$ & & \\
\hline & Adult/Spawning & & & & & & & & & $P$ & NS & & \\
\hline & Overwintering & \multicolumn{12}{|c|}{ No Data } \\
\hline & Migration & & & & & NS & NS & NS & NS & NS & NS & & \\
\hline \multirow[t]{6}{*}{ Longnose sucker } & Fry/Nursery & \multicolumn{12}{|c|}{ No Data } \\
\hline & Juvenile/Rearing & & & & & $P$ & $\mathrm{~A}$ & $?$ & $?$ & $P$ & $\mathrm{P}$ & & \\
\hline & Adult/Feeding & & & & & $P$ & A & $?$ & $?$ & $P$ & $P$ & & \\
\hline & Adult/Spawning & & & & & NS & NS & & & & & & \\
\hline & Overwintering & \multicolumn{12}{|c|}{ No Data } \\
\hline & Migration & \multicolumn{12}{|c|}{ No Data } \\
\hline \multirow[t]{6}{*}{ White sucker } & Fry/Nursery & & & & & & & Date & & & & & \\
\hline & Juvenile/Rearing & & & & & $\mathrm{A}$ & $\mathrm{A}$ & $?$ & $?$ & A & $P$ & & \\
\hline & Adult/Feeding & & & - & & $\mathrm{P}$ & $A$ & $?$ & $?$ & $\mathrm{P}$ & $P$ & 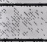 & \\
\hline & Adult/Spawning & & & & & NS & NS & & & & & & \\
\hline & Overwintering & & & & & & & Data & & & & & \\
\hline & Migration & & & & & NS & NS & NS & NS & NS & NS & & \\
\hline Emerald shiner & Fry/Nursery & & & & & & & Date & & & & & \\
\hline & Juvenile/Rearing & & & & & $\mathrm{A}$ & $P$ & $?$ & $?$ & $\mathrm{~A}$ & $\mathrm{~A}$ & & \\
\hline & Adult/Feeding & & & & & $P$ & $P$ & $?$ & $?$ & $\mathrm{~A}$ & $A$ & & \\
\hline & Adult/Spawning & & & 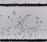 & & & & NS & NS & & & & \\
\hline & Overwintering & & & & & & & Data & & & & & \\
\hline & Migration & & & & & NS & NS & NS & NS & NS & NS & & \\
\hline Abundance rating: & $\begin{array}{l}P=\text { present } \\
A=\text { absent } \\
?=\text { suspected but } r \\
N S=\text { not sampled } \\
\text { Blank cell = life sta } \\
\text { Shaded cells }=\text { no }\end{array}$ & & & & & & & & & & & & \\
\hline
\end{tabular}


Table 15

Summary of Timing and Distribution for Fish Species - Segment 2

\begin{tabular}{|c|c|c|c|c|c|c|c|c|c|c|c|c|c|}
\hline \multirow[t]{2}{*}{ Species } & \multirow{2}{*}{$\begin{array}{l}\text { Life History } \\
\text { Stage/Activity }\end{array}$} & \multicolumn{12}{|c|}{ Month } \\
\hline & & $\mathrm{J}$ & $F$ & $\mathbf{M}$ & $\mathbf{A}$ & $M$ & $\mathrm{~J}$ & $\mathrm{~J}$ & A & $\mathrm{s}$ & 0 & $\mathrm{~N}$ & D \\
\hline \multirow[t]{6}{*}{ Walleye } & Fry/Nursery & \multicolumn{12}{|c|}{ No Data } \\
\hline & Juvenile/Rearing & & & & & $?$ & $?$ & $?$ & $?$ & $\mathrm{P}$ & $P$ & & \\
\hline & Adult/Feeding & & & & & $?$ & $?$ & $?$ & $?$ & $\mathrm{P}$ & $P$ & & \\
\hline & Adult/Spawning & & & & & NS & NS & & & & & & \\
\hline & Overwintering & \multicolumn{12}{|c|}{ No Data } \\
\hline & Migration & & & & & NS & NS & NS & NS & NS & NS & & \\
\hline \multirow[t]{6}{*}{ Northern pike } & Fry/Nursery & \multicolumn{12}{|c|}{ No Data } \\
\hline & Juvenile/Rearing & & & & & A & A & $?$ & $?$ & $\mathrm{~A}$ & $\mathrm{P}$ & & \\
\hline & Adult/Feeding & & & & & $A$ & $\mathrm{~A}$ & $?$ & $?$ & $\mathrm{P}$ & $P$ & & \\
\hline & Adult/Spawning & & & & & NS & NS & & & & & & \\
\hline & Overwintering & \multicolumn{12}{|c|}{ No Data } \\
\hline & Migration & & & & & NS & NS & NS & NS & NS & NS & & \\
\hline \multirow[t]{6}{*}{ Lake whitefish } & Fry/Nursery & \multicolumn{12}{|c|}{ No Data } \\
\hline & Juvenile/Rearing & & & & & NS & NS & $?$ & $?$ & NS & NS & & \\
\hline & Adult/Feeding & & & & & NS & NS & $?$ & $?$ & NS & NS & & \\
\hline & Adult/Spawning & & & & & & & & & NS & NS & & \\
\hline & Overwintering & \multicolumn{12}{|c|}{ No Data } \\
\hline & Migration & & & & & NS & NS & NS & NS & NS & NS & & \\
\hline \multirow[t]{6}{*}{ Mountain whitefish } & Fry/Nursery & \multicolumn{12}{|c|}{ No Data } \\
\hline & Juvenile/Rearing & & & & & $P$ & $A$ & $?$ & $?$ & $\mathrm{P}$ & $P$ & & \\
\hline & Adult/Feeding & & & & + & $\mathrm{P}$ & A & $?$ & $?$ & $\mathrm{P}$ & $\mathrm{P}$ & & \\
\hline & Adult/Spawning & & & & & & & & & NS & NS & & \\
\hline & Overwintering & \multicolumn{12}{|c|}{ No Data } \\
\hline & Migration & & & & & NS & NS & NS & NS & NS & NS & & \\
\hline \multirow{6}{*}{ Longnose sucker } & Fry/Nursery & \multicolumn{12}{|c|}{ No Data } \\
\hline & Juvenile/Rearing & & & & & $A$ & $A$ & $?$ & $?$ & $A$ & $P$ & & \\
\hline & Adult/Feeding & & & & & $P$ & $A$ & $?$ & $?$ & $A$ & $P$ & & \\
\hline & Adult/Spawning & & & & & NS & NS & & & & & & \\
\hline & Overwintering & \multicolumn{12}{|c|}{ No Data } \\
\hline & Migration & & & & & NS & NS & NS & NS & NS & NS & & \\
\hline \multirow[t]{6}{*}{ White sucker } & Fry/Nursery & \multicolumn{12}{|c|}{ No Data } \\
\hline & Juvenile/Rearing & & & & & $?$ & $?$ & $?$ & $?$ & $\mathrm{P}$ & $\mathrm{P}$ & & \\
\hline & Adult/Feeding & & & & & $?$ & $?$ & $?$ & $?$ & $\mathrm{P}$ & $P$ & & \\
\hline & Adult/Spawning & & & & & NS & NS & & & & & & \\
\hline & Overwintering & & & & & & & Data & & & & & \\
\hline & Migration & & & & & NS & NS & NS & NS & NS & NS & & \\
\hline Emerald shiner & Fry/Nursery & & & & & & & Date & & & & & \\
\hline & Juvenile/Rearing & & & & & NS & NS & $?$ & $?$ & NS & NS & & \\
\hline & Adult/Feeding & & & & & NS & NS & $?$ & $?$ & NS & NS & & \\
\hline & Adult/Spawning & & & & & & & NS & NS & & & & \\
\hline & Overwintering & & & & & & & Data & & & & & \\
\hline & Migration & & & & & NS & NS & NS & NS & NS & NS & & \\
\hline Abundance rating: & $\begin{array}{l}P=\text { present } \\
A=\text { absent } \\
?=\text { suspected but } \\
N S=\text { not sampled } \\
\text { Blank cell = life sta }\end{array}$ & & & & & & & & & & & & \\
\hline
\end{tabular}


Table 16

Summary of Timing and Distribution for Fish Species - Segment 3

\begin{tabular}{|c|c|c|c|c|c|c|c|c|c|c|c|c|c|}
\hline \multirow{2}{*}{ Species } & \multirow{2}{*}{$\begin{array}{c}\text { Life History } \\
\text { Stage/Activity }\end{array}$} & \multicolumn{12}{|c|}{ Month } \\
\hline & & $\mathbf{J}$ & $F$ & $\mathbf{M}$ & $\mathbf{A}$ & $M$ & $\mathbf{J}$ & $\mathbf{J}$ & A & $\mathbf{S}$ & 0 & $\mathbf{N}$ & D \\
\hline \multirow[t]{12}{*}{ Walleye } & Fry/Nursery & \multicolumn{12}{|c|}{ No Data } \\
\hline & Juvenile/Rearing & & & & & $?$ & $?$ & $?$ & $?$ & $P$ & $P$ & & \\
\hline & Adult/Feeding & & & & & $?$ & $?$ & $?$ & $?$ & $\mathrm{P}$ & $P$ & & \\
\hline & Adult/Spawning & & & & & NS & NS & & & & & & \\
\hline & Overwintering & \multicolumn{12}{|c|}{ No Data } \\
\hline & Migration & & & & & NS & NS & NS & NS & NS & NS & & \\
\hline & Fry/Nursery & \multicolumn{12}{|c|}{ No Data } \\
\hline & Juvenile/Rearing & & & & & $\mathrm{P}$ & A & $?$ & $?$ & A & $\mathrm{P}$ & & \\
\hline & Adult/Feeding & & & & & $P$ & $\mathrm{~A}$ & $?$ & $?$ & $\mathrm{P}$ & $\mathrm{P}$ & & \\
\hline & Adult/Spawning & & & & & NS & NS & & & & & & \\
\hline & Overwintering & \multicolumn{12}{|c|}{ No Data } \\
\hline & Migration & & & & & NS & NS & NS & NS & NS & NS & & \\
\hline \multirow[t]{6}{*}{ Lake whitefish } & Fry/Nursery & \multicolumn{12}{|c|}{ No Data } \\
\hline & Juvenile/Rearing & & & & & $?$ & $?$ & $?$ & $?$ & $\mathrm{P}$ & $\mathrm{A}$ & & \\
\hline & Adult/Feeding & & & & 2 & $?$ & $?$ & $?$ & $?$ & $P$ & $\mathrm{~A}$ & & \\
\hline & Adult/Spawning & & & & & & & & & $\mathrm{P}$ & A & & \\
\hline & Overwintering & \multicolumn{12}{|c|}{ No Data } \\
\hline & Migration & & & & & NS & NS & NS & NS & NS & NS & & \\
\hline \multirow[t]{6}{*}{ Mountain whitefish } & Fry/Nursery & \multicolumn{12}{|c|}{ No Data } \\
\hline & Juvenile/Rearing & & & & & A & A & $?$ & ? & A & $\mathrm{P}$ & & \\
\hline & Adult/Feeding & & & & & $P$ & $A$ & $?$ & $?$ & $A$ & $\mathrm{P}$ & & \\
\hline & Adult/Spawning & & & & & & & & & NS & NS & & \\
\hline & Overwintering & \multicolumn{12}{|c|}{ No Data } \\
\hline & Migration & & & & & NS & NS & NS & NS & NS & NS & & \\
\hline \multirow[t]{6}{*}{ Longnose sucker } & Fry/Nursery & \multicolumn{12}{|c|}{ No Data } \\
\hline & Juvenile/Rearing & & & & & A & A & $?$ & $?$ & $\mathrm{P}$ & $P$ & & \\
\hline & Adult/Feeding & & & & & $\mathrm{P}$ & $A$ & $?$ & $?$ & $\mathrm{P}$ & $\mathrm{P}$ & & \\
\hline & Adult/Spawning & & & & & NS & NS & & & & & & \\
\hline & Overwintering & \multicolumn{12}{|c|}{ No Data } \\
\hline & Migration & & & & & NS & NS & NS & NS & NS & NS & & \\
\hline \multirow[t]{6}{*}{ White sucker } & Fry/Nursery & \multicolumn{12}{|c|}{ No Data } \\
\hline & Juvenile/Rearing & & & & & $\mathrm{P}$ & A & $?$ & $?$ & A & $P$ & & \\
\hline & Adult/Feeding & & & & & $\mathrm{P}$ & A & $?$ & $?$ & $\mathrm{P}$ & $P$ & & \\
\hline & Adult/Spawning & & & & & NS & NS & & & & & & \\
\hline & Overwintering & \multicolumn{12}{|c|}{ No Data } \\
\hline & Migration & & & & & NS & NS & NS & NS & NS & NS & & \\
\hline Emerald shiner & Fry/Nursery & & & & & & & Dat & & & & & \\
\hline & Juvenile/Rearing & & & & & NS & NS & $?$ & $?$ & NS & NS & & \\
\hline & Adult/Feeding & & & & & NS & NS & $?$ & $?$ & NS & NS & & \\
\hline & Adult/Spawning & & & & & & & NS & NS & & & & \\
\hline & Overwintering & & & & & & & Dat & & & & & \\
\hline Abundance rating: & $\begin{array}{l}P=\text { present } \\
A=\text { absent } \\
?=\text { suspected but } \\
\text { NS }=\text { not sampled } \\
\text { Blank cell = life sta } \\
\text { Shaded cells = no }\end{array}$ & & & & & & & & & & & & \\
\hline
\end{tabular}


Table 17

Summary of Timing and Distribution for Fish Species - Segment 4

\begin{tabular}{|c|c|c|c|c|c|c|c|c|c|c|c|c|c|}
\hline \multirow[t]{2}{*}{ Species } & \multirow{2}{*}{$\begin{array}{c}\text { Life History } \\
\text { Stage/Activity }\end{array}$} & \multicolumn{12}{|c|}{ Month } \\
\hline & & $\mathbf{J}$ & $\mathbf{F}$ & $M$ & A & $M$ & $\mathbf{J}$ & $\mathrm{J}$ & A & $\mathbf{s}$ & 0 & $\mathrm{~N}$ & D \\
\hline \multirow[t]{6}{*}{ Walleye } & Fry/Nursery & \multicolumn{12}{|c|}{ No Data } \\
\hline & Juvenile/Rearing & & & & NS & $?$ & $?$ & $?$ & $?$ & $P$ & $\mathrm{P}$ & & \\
\hline & Adult/Feeding & & & & NS & $?$ & $?$ & $?$ & $?$ & $\mathrm{P}$ & $P$ & & \\
\hline & Adult/Spawning & & & & NS & NS & NS & & & & & & \\
\hline & Overwintering & \multicolumn{12}{|c|}{ No Data } \\
\hline & Migration & & & & NS & NS & NS & NS & NS & NS & NS & 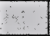 & \\
\hline \multirow{6}{*}{ Northern pike } & Fry/Nursery & \multicolumn{12}{|c|}{ No Data } \\
\hline & Juvenile/Rearing & & & & $\mathrm{P}$ & $\mathrm{P}$ & $A$ & $?$ & $?$ & A & $\mathrm{P}$ & & \\
\hline & Adult/Feeding & & & & $P$ & $P$ & A & $?$ & $?$ & $P$ & $P$ & & \\
\hline & Adult/Spawning & & & & $\mathrm{P}$ & $A$ & & & & & & & \\
\hline & Overwintering & \multicolumn{12}{|c|}{ No Data } \\
\hline & Migration & 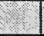 & & & NS & NS & NS & NS & NS & NS & NS & & \\
\hline \multirow[t]{6}{*}{ Lake whitefish } & Fry/Nursery & \multicolumn{12}{|c|}{ No Data } \\
\hline & Juvenile/Rearing & & & & NS & $\mathrm{P}$ & $\bar{A}$ & $?$ & $?$ & $\mathrm{P}$ & $\mathrm{P}$ & & \\
\hline & Adult/Feeding & & & & NS & $\mathrm{P}$ & A & $?$ & $?$ & $\mathrm{P}$ & $\mathrm{P}$ & & \\
\hline & Adult/Spawning & & & & NS & & & & & $\mathrm{P}$ & $\mathrm{A}$ & & \\
\hline & Overwintering & \multicolumn{12}{|c|}{ No Data } \\
\hline & Migration & & & & NS & NS & NS & NS & NS & NS & NS & & \\
\hline \multirow[t]{6}{*}{ Mountain whitefish } & Fry/Nursery & \multicolumn{12}{|c|}{ No Data } \\
\hline & Juvenile/Rearing & & & & NS & $P$ & A & $?$ & $?$ & $P$ & $\mathrm{P}$ & & \\
\hline & Adult/Feeding & & & 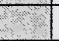 & NS & $P$ & $\bar{A}$ & $?$ & $?$ & $P$ & $\mathrm{P}$ & & \\
\hline & Adult/Spawning & & & 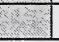 & NS & & & & & A & $\mathrm{P}$ & & \\
\hline & Overwintering & \multicolumn{12}{|c|}{ No Data } \\
\hline & Migration & & & & NS & NS & NS & NS & NS & NS & NS & & \\
\hline \multirow[t]{6}{*}{ Longnose sucker } & Fry/Nursery & \multicolumn{12}{|c|}{ No Data } \\
\hline & Juvenile/Rearing & & & & NS & $\mathrm{A}$ & $A$ & $?$ & $?$ & $\mathrm{P}$ & $P$ & & \\
\hline & Adult/Feeding & & & & NS & $\mathrm{P}$ & A & $?$ & $?$ & $P$ & $P$ & & \\
\hline & Adult/Spawning & & & & NS & NS & NS & & & & & & \\
\hline & Overwintering & \multicolumn{12}{|c|}{ No Data } \\
\hline & Migration & & & & NS & NS & NS & NS & NS & NS & NS & & \\
\hline \multirow[t]{6}{*}{ White sucker } & Fry/Nursery & \multicolumn{12}{|c|}{ No Data } \\
\hline & Juvenile/Rearing & & & & NS & $\mathrm{P}$ & A & $?$ & $?$ & $P$ & $P$ & & \\
\hline & Adult/Feeding & & & & NS & $\mathrm{P}$ & $A$ & $?$ & $?$ & $P$ & $\mathrm{P}$ & & \\
\hline & Adult/Spawning & & & {[} & NS & NS & NS & & & & & & \\
\hline & Overwintering & & & & & & No & Data & & & & & \\
\hline & Migration & ma & & & NS & NS & NS & NS & NS & NS & NS & & \\
\hline Emerald shiner & Fry/Nursery & & & & & & No & Data & & & & & \\
\hline & Juvenile/Rearing & & & & NS & $?$ & $?$ & $?$ & $?$ & $\bar{A}$ & $A$ & & \\
\hline & Adult/Feeding & & & & NS & $?$ & $?$ & $?$ & $?$ & $P$ & $A$ & & \\
\hline & Adult/Spawning & & & & NS & & & NS & NS & & & & \\
\hline & Overwintering & & & & & & No & Data & & & & & \\
\hline & Migration & & & & NS & NS & NS & NS & NS & NS & NS & & \\
\hline Abundance rating: & $\begin{array}{l}P=\text { present } \\
A=\text { absent } \\
?=\text { suspected but } r \\
\text { NS = not sampled } \\
\text { Blank cell = life sta } \\
\text { Shaded cells = no }\end{array}$ & & $x$ & iented & ted & & 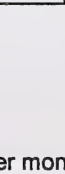 & 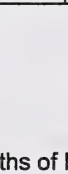 & 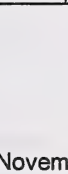 & & & & \\
\hline
\end{tabular}


Table 18

Summary of Timing and Distribution for Fish Species - Segment 5

\begin{tabular}{|c|c|c|c|c|c|c|c|c|c|c|c|c|c|}
\hline \multirow[t]{2}{*}{ Species } & \multirow{2}{*}{$\begin{array}{l}\text { Life History } \\
\text { Stage/Activity }\end{array}$} & \multicolumn{12}{|c|}{ Month } \\
\hline & & $\mathbf{J}$ & $\mathbf{F}$ & $M$ & A & $M$ & $\mathrm{~J}$ & $\mathrm{~J}$ & A & $\mathrm{s}$ & 0 & $\mathbf{N}$ & D \\
\hline \multirow[t]{6}{*}{ Walleye } & Fry/Nursery & \multicolumn{12}{|c|}{ No Data } \\
\hline & Juvenile/Rearing & & & & NS & $A$ & $A$ & $?$ & $?$ & $A$ & $A$ & & \\
\hline & Adult/Feeding & & & 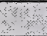 & NS & $P$ & $\mathrm{P}$ & $?$ & $?$ & $P$ & A & & \\
\hline & Adult/Spawning & & & & NS & NS & NS & & & & & & \\
\hline & Overwintering & \multicolumn{12}{|c|}{ No Data } \\
\hline & Migration & & & & NS & NS & NS & NS & NS & NS & NS & & \\
\hline \multirow[t]{6}{*}{ Northern Pike } & Fry/Nursery & \multicolumn{12}{|c|}{ No Data } \\
\hline & Juvenile/Rearing & & & & $P$ & $P$ & $\mathrm{P}$ & $?$ & $?$ & $A$ & $A$ & & \\
\hline & Adult/Feeding & & & & $P$ & $P$ & $P$ & $?$ & $?$ & $\mathrm{P}$ & A & & \\
\hline & Adult/Spawning & & & & $P$ & $\mathrm{P}$ & $P$ & & & & & & \\
\hline & Overwintering & \multicolumn{12}{|c|}{ No Data } \\
\hline & Migration & & & & NS & NS & NS & NS & NS & NS & NS & & \\
\hline \multirow[t]{6}{*}{ Lake whitefish } & Fry/Nursery & \multicolumn{12}{|c|}{ No Data } \\
\hline & Juvenile/Rearing & & & & NS & $\mathrm{A}$ & $\mathrm{P}$ & $?$ & $?$ & $?$ & $?$ & & \\
\hline & Adult/Feeding & & & & NS & $\mathrm{P}$ & $P$ & $?$ & $?$ & $?$ & $?$ & & \\
\hline & Adult/Spawning & & & & NS & & & & & NS & NS & & \\
\hline & Overwintering & \multicolumn{12}{|c|}{ No Data } \\
\hline & Migration & & & & NS & NS & NS & NS & NS & NS & NS & & \\
\hline \multirow[t]{6}{*}{ Mountain whitefish } & Fry/Nursery & \multicolumn{12}{|c|}{ No Data } \\
\hline & Juvenile/Rearing & & & & NS & $A$ & $\mathrm{~A}$ & $?$ & $?$ & $?$ & $?$ & & \\
\hline & Adult/Feeding & & & & NS & $\mathrm{P}$ & $\mathrm{A}$ & $?$ & $?$ & $?$ & $?$ & & \\
\hline & Adult/Spawning & & & & NS & error & & & & NS & NS & & \\
\hline & Overwintering & \multicolumn{12}{|c|}{ No Data } \\
\hline & Migration & & & & & NS & NS & NS & NS & NS & NS & & \\
\hline \multirow[t]{6}{*}{ Longnose sucker } & Fry/Nursery & \multicolumn{12}{|c|}{ No Data } \\
\hline & Juvenile/Rearing & & & & $A$ & A & $P$ & $?$ & $?$ & $?$ & $?$ & & \\
\hline & Adult/Feeding & & & & $\mathrm{P}$ & $P$ & $\mathrm{P}$ & $?$ & $?$ & $?$ & $?$ & & \\
\hline & Adult/Spawning & & & & $A$ & $P$ & $P$ & & & & & & \\
\hline & Overwintering & \multicolumn{12}{|c|}{ No Data } \\
\hline & Migration & & & & NS & NS & NS & NS & NS & NS & NS & & \\
\hline \multirow[t]{6}{*}{ White sucker } & Fry/Nursery & \multicolumn{12}{|c|}{ No Data } \\
\hline & Juvenile/Rearing & & & & NS & A & $\mathrm{P}$ & $?$ & $?$ & $\mathrm{P}$ & $\mathrm{P}$ & & \\
\hline & Adult/Feeding & & & & NS & $P$ & $\mathrm{P}$ & $?$ & $?$ & $\mathrm{P}$ & $\mathrm{P}$ & & \\
\hline & Adult/Spawning & & & & NS & $P$ & $\mathrm{P}$ & & & & & & \\
\hline & Overwintering & & & & & & No & Jata & & & & & \\
\hline & Migration & & & & NS & NS & NS & NS & NS & NS & NS & & \\
\hline Emerald shiner & Fry/Nursery & & & & & & No & Data & & & & & \\
\hline & Juvenile/Rearing & & & & NS & $A$ & $P$ & $?$ & $?$ & $?$ & $?$ & & \\
\hline & Adult/Feeding & & & & NS & $\mathrm{P}$ & $\mathrm{P}$ & $?$ & $?$ & ? & $?$ & & \\
\hline & Adult/Spawning & & & & NS & NS & NS & NS & NS & NS & NS & & \\
\hline & Overwintering & & & & & & & Jata & & & & & \\
\hline & Migration & & & & NS & NS & NS & NS & NS & NS & NS & & \\
\hline Abundance rating: & $\begin{array}{l}P=\text { present } \\
A=\text { absent } \\
?=\text { suspected but } r \\
N S=\text { not sampled } \\
\text { Blank cell = life stas }\end{array}$ & & & & & & & & & & & & \\
\hline
\end{tabular}




\section{Suitability of Key Species}

Walleye, northern pike, lake whitefish, mountain whitefish, goldeye, longnose sucker, white sucker and emerald shiner are regionally important fish species and are some of the most abundant large fish in the Lesser Slave River. It is suspected that each of these species make substantial use of the Lesser Slave River for all or many of their critical life history activities and are suitable key species for an IFN study.

Walleye is ranked as a sensitive species of special concern in the Province of Alberta and there is evidence of declining abundance in the Lesser Slave River basin.

Longnose sucker is one of the most abundant in the Lesser Slave River, specifically the upstream half of the river and has also been selected as a key indicator resource (KIR) species for examining potential impacts from pulp mill effluent. Although it is not an important commercial, sport or subsistence species, it has been selected as a sentinel species for environmental effects monitoring (EEM) programs for the Lesser Slave River, and there is a considerable amount of available data for this species

\section{Areas of Concern}

The primary area of concern for fish populations in the Lesser Slave River relative to IFN is the winter period when base flows are low. From the available fisheries information, this would primarily be a concern for northern pike, as the population for this species shows a high level of use of the Lesser Slave River in the winter. At this time, overwintering by other species cannot be ruled out as most have been sampled in the mainstem in late fall.

A second area of concern is to document spawning habitat, particularly fall spawning since reduced flows during the winter may affect the survivability of developing embryos during the winter. 


\section{INSTREAM FLOW NEEDS ASSESSMENT FRAMEWORK}

\subsection{Overview}

The general framework being proposed for the Lesser Slave River IFN study is based on the principles of the Instream Flow Incremental Methodology (IFIM) (Bovee et al. 1998). The IFIM is a decision support system developed by the U.S. Fish and Wildlife Service designed to help solve water resource allocation problems. Although many of the tools developed for use with IFIM are only applicable to open-water conditions, there are typical steps that should be followed to support rational water management decisions. Several key principles that are particularly relevant to a successful IFN study on the Lesser Slave River include:

- agreement on the approach by all stakeholders at the planning stage;

- assemble an inter-disciplinary team to conduct the work;

- select an appropriate method to address specific problems; and,

- identify concise study objectives that are feasible in terms of data collection limitations, modelling approaches, and realistic timeline constraints.

Early applications of the IFIM were often single-species focussed and often resulted in single value minimum flow recommendations. The latest thinking in IFN science is that multiple ecosystem components and processes must be incorporated to achieve aquatic ecosystem protection (Annear et al. 2002). In developing a science-based IFN approach that can be considered protective of the aquatic ecosystem, the IFN study plan must consider flow requirements beyond a few key fish species. Recent IFN work conducted in Alberta (Clipperton et al. 2002, 2003) has incorporated the concepts of the natural flow paradigm (Poff et al. 1997; Richter et al. 1997) in the formulation of an IFN determination by considering multiple ecosystem components.

A range of possible approaches to developing an IFN that incorporates multiple ecosystem components should therefore be considered and may range from office-based techniques to detailed field studies. The selection of an approach and level of effort is often more reflective of the potential for water management to alter a particular component of the ecosystem and the 
potential for conflict amongst water users that correspond to the flow ranges when each ecosystem component is being considered.

\subsubsection{Winter IFN Approaches}

Office-based approaches can and have been applied in northern jurisdictions, including for the winter season, in situations where all interested parties can agree to the recommended flow regime (C. Estes, pers. comm.). Tennant (1976) evaluations have been applied in Alaska for the last 15 years (Estes 1998). A Tessmann evaluation (Tessmann 1979) had previously been conducted for the Lesser Slave River and offers a low-cost approach to defining an IFN. Office techniques tend to produce conservative flow recommendations during the winter months, which is appropriate if data are not available to indicate more water can be diverted from the watercourse during a naturally stressful season without increasing this level of stress. If an office-approach is not agreed upon by all stakeholders, more detailed studies are required.

Annear et al. (2002) provides a detailed review of applicability of available IFN field techniques. Many of the field approaches available were regionally developed with a particular type of stream in mind and none deal directly with ice-covered conditions in the winter. Regionally developed field approaches can come under criticism when applied in jurisdictions beyond that which they were developed. In selecting an appropriate method, particularly in circumstances where conflicts amongst water users is expected, the only approach that can often be agreed upon by all interested parties is to conduct a detailed site-specific habitat modelling evaluation. Conducting site-specific studies may not alter the conclusion of an office-based recommendation by very much; however, there is more confidence that the answer is applicable to the system at hand as it is considered scientifically credible.

Participants at an IFN workshop held for the NRBS identified winter as a critical period for consideration in an IFN study; however, no approaches were recommended to directly evaluate winter conditions at that time (Walder 1996). A decade after the NRBS workshop, another workshop was held for the Athabasca River IFN project being conducted by CEMA to detail a work plan for conducting a winter IFN study (Golder 2004). The results from that study provide guidance regarding the options available for having a winter component in an IFN study. A product from the Athabasca River IFN project has been the development of a tool with the 
potential to conduct under-ice habitat modelling using the River2D model developed at the University of Alberta.

Alternate winter approaches have been applied in Quebec, mostly for hydroelectric developments, where a steady winter flow is prescribed for the entire winter period. The determination of the flow has been based on the amount of fall habitat available for fall spawners such that a loss of incubating eggs is avoided during the winter. A similar approach could be developed by the IFNTC for application on the Lesser Slave River if fall spawning locations are identified.

\subsection{Lesser Slave River IFN Framework}

A framework outlining the necessary steps to complete an IFN evaluation was developed based on the findings of the background summaries. Each step is not necessarily essential to the development of an IFN; however, there are risks and uncertainty associated with each step should it not be completed. Some data are essential if an IFN recommendation beyond an office-based approach is desired.

The IFN framework is organized using the five ecosystem components identified by Annear et al. (2002), which include hydrology, geomorphology, water quality, biology and connectivity. Under the biological component, information on benthic invertebrates, fish and riparian ecosystems will be included. The connectivity component spans several different topics included in our summary and can be divided into longitudinal and lateral connectivity.

Conducting an IFN study with objective of achieving ecosystem protection is complex. A flow chart illustrating the decision points in the process and the connection amongst the different components is provided in Figure 26. Numerous decisions must be made throughout the study and an evaluation of results and the future steps necessary will be required at several points in the process. Data collection can help reduce uncertainty; however, there are also situations where the cost of additional data collection may outweigh the benefit it provides. Decisions will have to be made to either continue with more data collection or determine the best use of the existing data and accepting the uncertainty that exists. 
Figure 26 Lesser Slave River Conceptual IFN Framework Flow Diagram

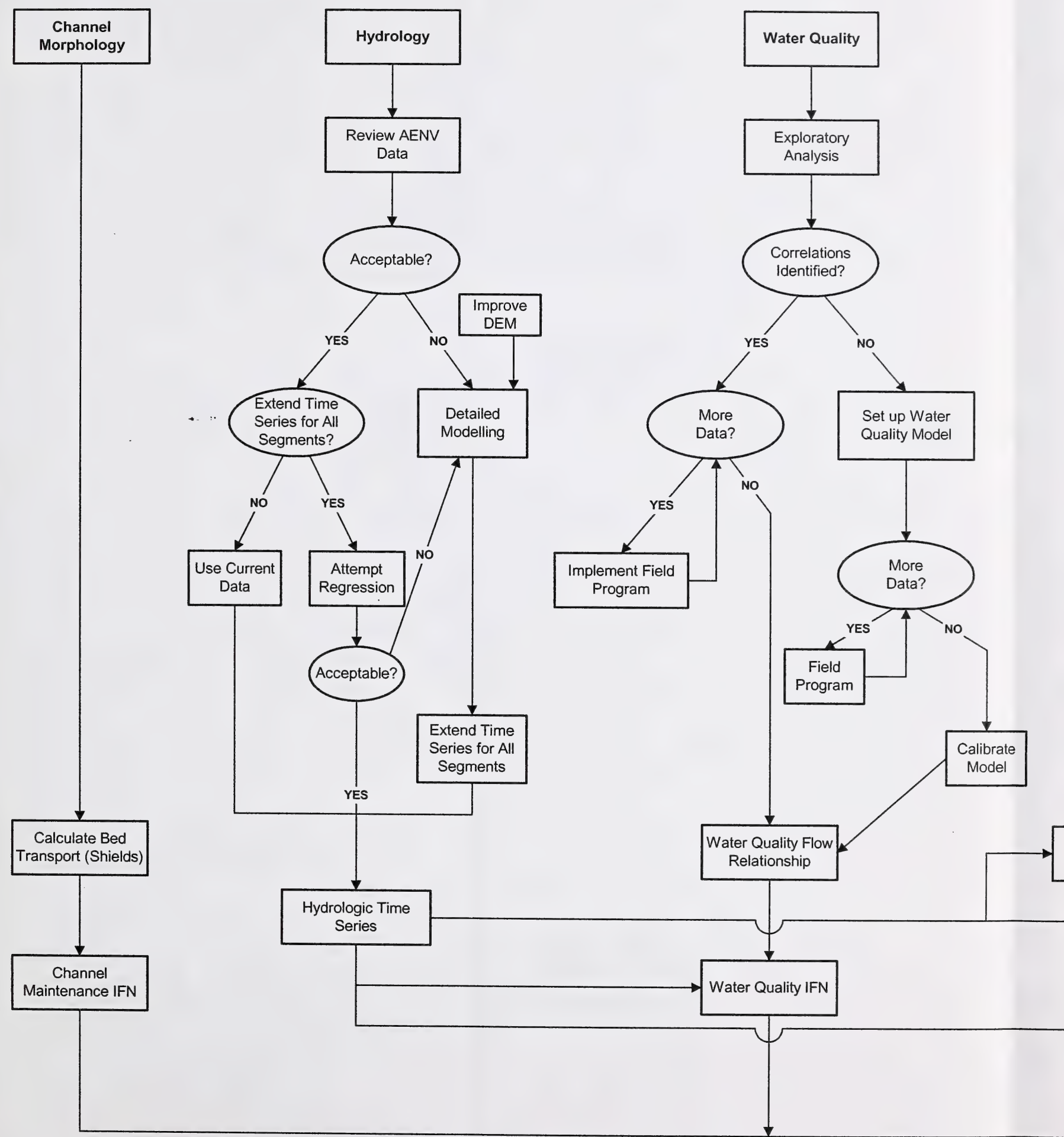




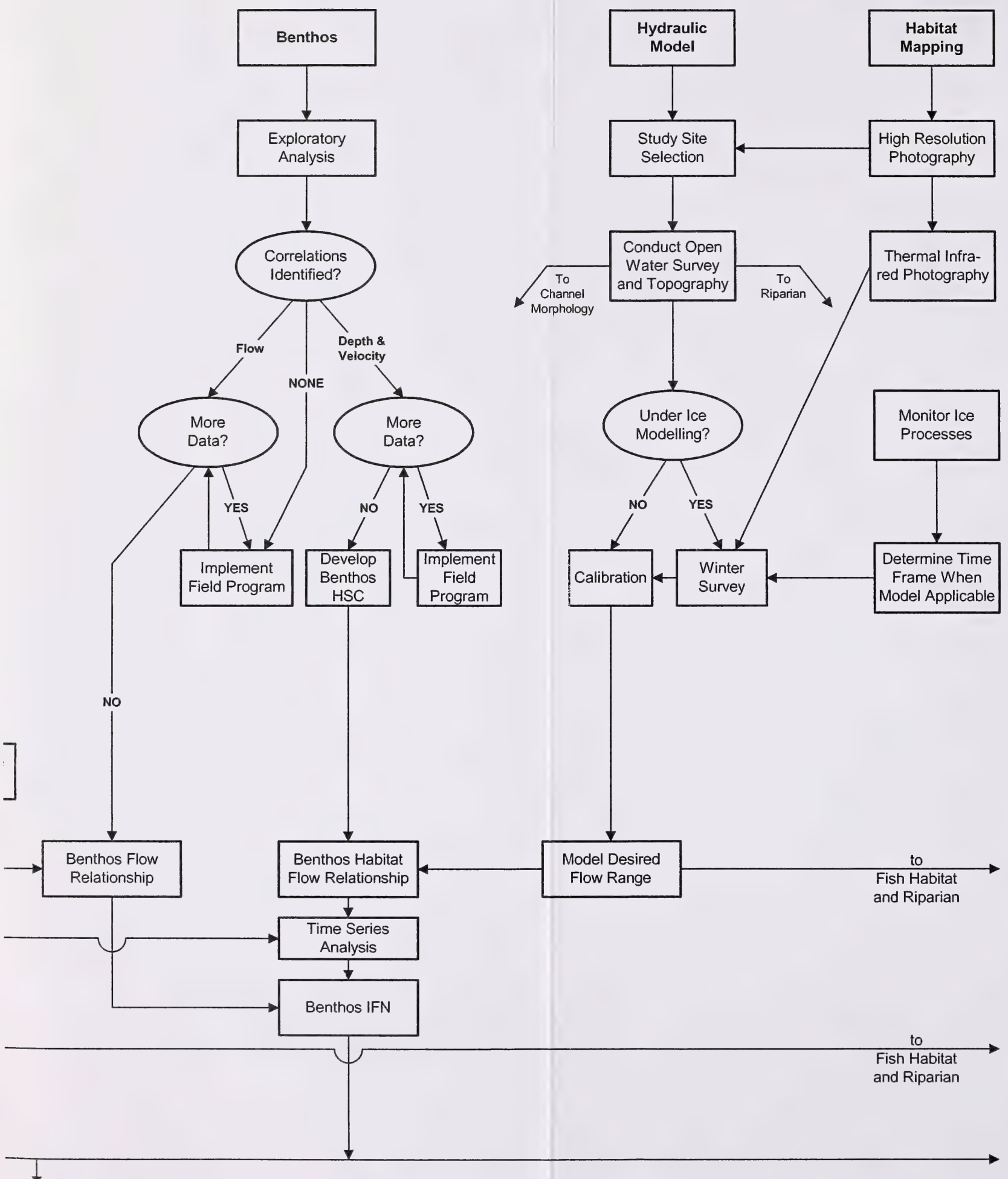


Figure 26 Lesser Slave River Conceptual IFN Framework Flow Diagram (continued)

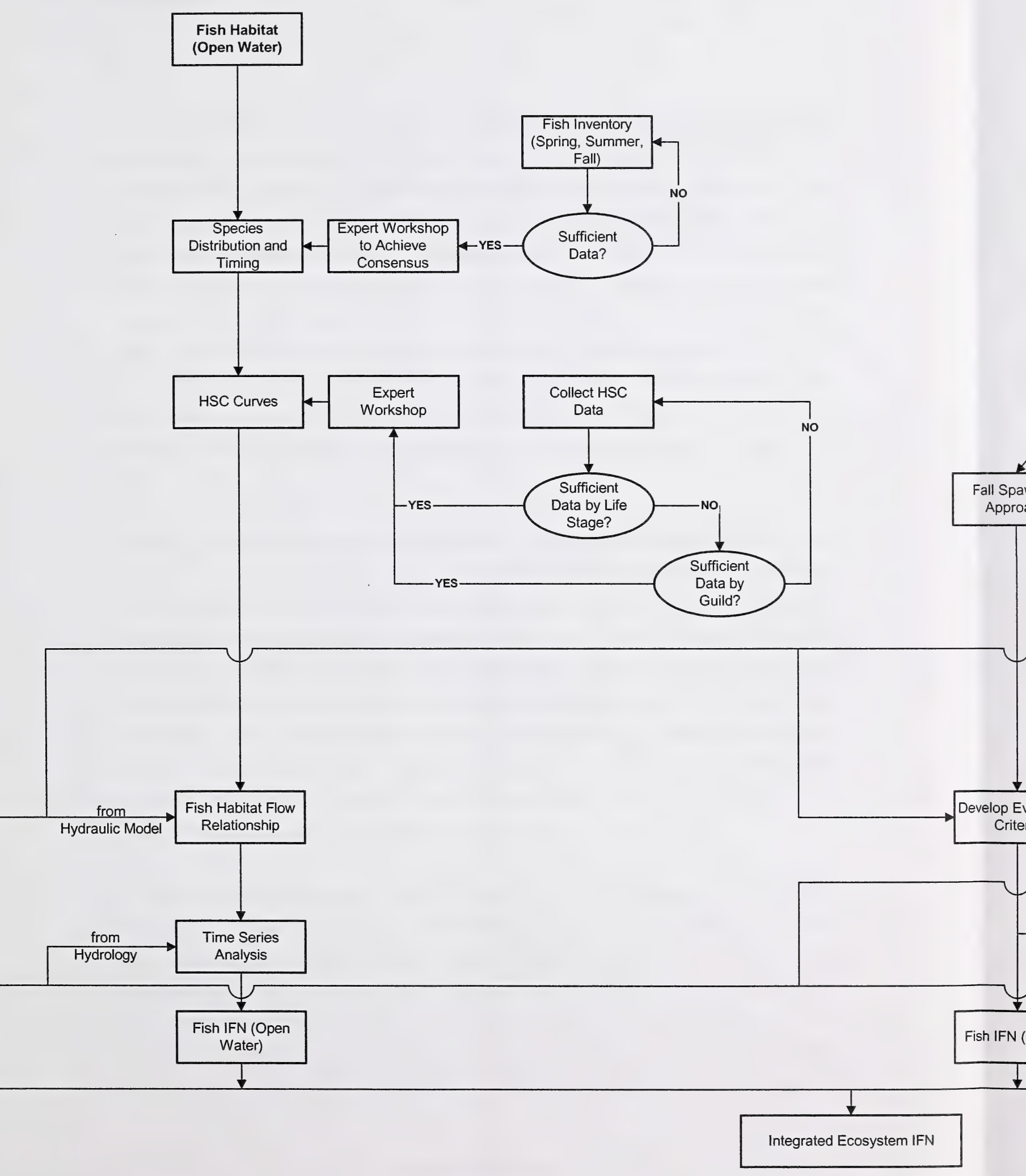




\subsection{Hydrology}

Based on the finding from the hydrology review, an IFN study could proceed with the hydrology data currently available using a 30 year flow record for each segment. The availability of a naturalized and a synthesized regulated flow time series for each segment will allow for a wide number of evaluations to be conducted for the development of an IFN and for the evaluation of different water management alternatives. Although a statistical assessment was not performed to identify the degree to which the flow regime has been altered as a result of flow regulation, the comparison of basic flow statistics indicates that the flow regime has not undergone a dramatic change. More detailed tools for evaluating the degree of hydrologic change are available, such as the indicators of hydrologic alteration (IHA, Richter et al. 1996). The long-term daily flow records would allow for this type of analysis; however, the results would indicate areas in the hydrograph that have been altered the most but it will not define an acceptable flow regime to be used as an IFN.

Two main recommendations were made for reducing the uncertainty in the hydrology component. The first recommendation was to conduct a review of the flow naturalization method and results to better understand some discrepancies noticed between the observed (historic recorded) and synthesized (naturalized and regulated) flows. Development of a more detailed naturalization model may be possible to reduce the uncertainty in the data. Addressing any uncertainty in the naturalized flow data up front may reduce the risk involved with proceeding without conducting a more detailed review of the naturalized flow series and having the results rejected or changed at a later date if any concern is raised about the synthetic flow time series. Many of the steps involved in an IFN study are directly linked to the hydrology data, and any errors in the hydrology data would be carried throughout the entire process.

The second recommendation was to extend the naturalized flow time series back to 1916 for each of the gauged tributaries to allow for a comparable period of record for segments 1,2 and 3 . Again, extending the time series is not essential since a reasonable time series covering 30 years is available, which covers a wet and dry hydrologic cycle. However, some differences were noted between the 1916-1999 and the 1970-1999 time series and the longer time series would capture more of the variability in the flow conditions on the Lesser Slave River and potentially reduce the uncertainty in the final analysis if a better fit can be established between the 
synthesized and recorded data. The potential risk of using a shorter period of record is that it may not be as representative of the longer-term conditions, particularly in the case of extreme events in the Lesser Slave River, which may effect the evaluation of the IFN since many aspects of an IFN evaluation rely on hydrological statistics.

\subsection{Channel Morphology}

A primary assumption in conducting an IFIM study and using habitat modelling tools is that the channel is in a state of dynamic equilibrium (Bovee et al. 1998). Based on the review of available data, it is not apparent that the channel within Segment 4 has reached a state of equilibrium after the construction of the weir and channel cutoffs. The rate of change appears to be very gradual, however, and at this point channel morphology issues do not appear to be of concern to proceeding with an IFN study. Detailed monitoring studies could be designed to better document the changing channel in Segment 4; however, these studies would likely require decades before any useful information was available. No issues with channel morphology are apparent within the lower segments, and the paucity of data should not be a limiting factor in conducting an IFN study.

The risk of proceeding with an IFN investigation at this time would be that a study site measured to represent current habitat conditions within Segment 4 may no longer accurately represent future habitat conditions. Recommendations based on the habitat conditions today may no longer provide suitable habitat conditions under a different channel form. However, the risk of this is considered small due to the gradual change observed to date. Some caution should be placed on this recommendation as the period after the weir was installed has been relatively dry. An assessment of channel change after the next major flood (1:10 or greater) may be warranted.

Inclusion of a channel morphology component in the IFN is possible with existing and future data likely to be collected for other components of the IFN study. Calculations of the initiation of bed transport have been used in Alberta in previous studies to define a range of channel morphology flows (Clipperton et al. 2003). The data required for this approach would include the D50 substrate size and hydraulic gradient, both of which would be collected as a component of establishing a habitat modelling site and are already available for Segment 4. 


\subsubsection{Ice Processes}

In some systems, dynamic ice processes play an important role in defining the morphology of the channel. It was determined that dynamic ice processes are not a concern on the Lesser Slaver River and studies designed to assist with an understanding of ice processes in order to define potential ice effects on channel morphology are not required. Understanding ice processes is still important for the Lesser Slave River, but more to do with understanding overwintering habitat conditions and are discussed in the fish habitat section.

\subsection{Water Quality}

The availability of water quality data is generally good for an IFN study of the Lesser Slave River. No major data gaps were identified, although the data are not evenly distributed either spatially or temporally. Several options are available for proceeding with a water quality evaluation to derive an IFN. The recommended first step would be to conduct an exploratory correlation analysis to help identify which, if any, water quality variables are sensitive to flow in the Lesser Slave River. Although a hydrodynamic model (CE-QUAL-W2), which could also be calibrated to predict water quality, has been calibrated for the Lesser Slave River, water quality models can be very labour intensive and expensive to fully calibrate and run. Prior to proceeding to a modelling exercise, identifying parameters sensitive to flow would at a minimum provide a level of screening so that only the most sensitive variables would need to be modelled. Digital elevation model (DEM) data were apparently used to define some of the cross-section parameters in the model (P. McEachern, pers. comm.). This may be a cause for concern as the DEM provided to Golder for this project indicated an increase in river elevation in a downstream direction over a large portion of the Lesser Slave River (i.e., the river was flowing uphill), and the use of these data for any portion of model development should be critically reviewed.

The initial review showed that under typical flow conditions in the Lesser Slave River, concentrations of nutrients and certain metals are occasionally above chronic water quality guidelines for the protection of aquatic life. Some guideline exceedances by these parameters were observed in all river sections, including Section 5 located upstream of wastewater discharges, suggesting they partly reflect lake water quality. However, there were a larger number of values above guidelines in segments 1,2 and 3 (downstream of the pulp mill) than in 
upstream Segments 4 and 5, especially for phosphorus and nitrogen, reflecting nutrient inputs from pulp mill effluent. Data collected by AENV (2003) during an extreme low flow event in 1999 also showed that oxygen concentration can drop below guidelines during unusually low flows. Clearly, there is a threshold flow where DO becomes unacceptable. Identifying the threshold may be possible using water quality models; however, the threshold appears to occur at flows lower than natural low flows and it is likely that the flow requirements from another ecosystem component would preclude such flow occurrences.

A key decision point would exist after the initial correlation analysis is completed, to decide on the benefits of proceeding with water quality modelling. The existing data appear to be sufficient to calibrate the model, allowing for almost immediate application of the model if desired. However, even with a water quality model ready for use, modelling can be a time consuming and costly exercise. If low DO during the winter was determined to be the primary concern, the U.S. EPA WASP model, which has also been set up for the Lesser Slave River, would be available to use for under-ice conditions (Golder 2000).

\subsection{Biological Processes - Riparian Ecosystems}

Based on the initial review of information on the Lesser Slave River riparian ecosystems, there does not appear to be any immediate concern for riparian ecosystem function with respect to the existing changes in the flow regime. Although the flow regime in the Lesser Slaver River is in the range of what would be considered flows important to riparian systems (typically in the higher range of flows), there is generally a poor understanding of the link between flow regime and boreal riparian ecosystems. The preliminary assessment is based somewhat on what is known about the response of cottonwood forests to changes in flow.

Changes to the riparian community were observed from air photos; however, they may be a result of the channelization works and increased development in the area rather than to the change in flow regime. There is also the potential that channel degradation in Segment 4 as a result of channelization may be resulting in drought stress within the riparian forest and this should be confirmed by a field investigation. Regardless of the driver, changes to the riparian ecosystem can have an effect on the habitat conditions in the Lesser Slave River and should be investigated. Additional historical air photo analysis would be warranted to identify rates of natural channel 
migration and to determine changes in the riparian community over a longer time frame. Some ground-truthing studies to confirm changes in the riparian community structure, age and to assess recruitment locations are required to confirm what was suspected from the air photo interpretation. Field investigations should also be directed at understanding the cause of tree stress observed within Segment 4. Identification of major recruitment years may also be possible, and related back to flow conditions during the recruitment year.

Inclusion of a riparian component in the IFN would be possible at a cursory level using data collected for other components of the IFN study. If major recruitment years can be identified from air photos or field visits, some information on the flow conditions during those recruitment events may be possible. Assuming study sites will be surveyed for fish habitat modelling, information on bankfull elevation and extent of the floodplain and riparian community could be collected with little additional effort. Gom and Mahoney (2002) developed an approach to define riparian flow requirements using bankfull conditions and hydrological data. Although this approach was developed for cottonwood forests, as we are lacking specific information on the boreal forest response to altered flow regimes (except for major hydropeaking operations), this approach would likely be conservative and reasonable in the short term. Understanding the link between boreal forests and the flow regime is a major data gap; however, applying the approach that was used for southern Alberta would be a suitable surrogate at this stage in the IFN process and could be adjusted in the future when the linkage between flow and boreal forest riparian systems is better understood. Conducting a more detailed airphoto analysis and collecting some simple field data would help in understanding the status of the riparian community on the Lesser Slave River.

\subsection{Biological Processes - Benthic Invertebrates}

Multiple years of benthic invertebrate data are available due to monitoring requirements at Slave Lake Pulp. Sufficient benthic invertebrate data exists to conduct an exploratory analysis to identify sensitive taxa and potentially develop a relationship between abundance, richness or diversity to flow, depth or velocity. This step is recommended to provide additional assurance that conditions for benthic invertebrates have not been overlooked in the final analysis. Since the objective of the Lesser Slave River is to achieve ecosystem protection, inclusion of as many ecosystem components as possible is recommended. The preferred outcome from this process 
would be an empirical relationship that would allow for an evaluation of benthic invertebrate response to changes in flow, although it may simply guide future studies to collect data identified to be sensitive to flow based on the results of the exploratory analysis.

Most of the benthic invertebrate data that has been collected has also involved measurement of depth and velocity at the sampling locations. If the initial correlation analysis indicates a relationship exits between one of the population indices (e.g., diversity, richness or abundance) and depth or velocity, there is a possibility that depth and/or velocity suitability criteria could be created using the existing dataset. This would eventually allow for the development of a benthic invertebrate weighted useable area relationship by using the same habitat modelling approaches used for fish.

There would be a key decision point for the IFNTC after completion of the initial exploratory analysis to decide if a more detailed analysis (i.e., to proceed with a habitat modelling type of approach) is warranted. One of the biggest advantages of including a benthic invertebrate component is that an existing monitoring program for the pulp mill is in place and will continue into the future. This would provide an opportunity to determine if the recommended flow regime is achieving the ecosystem protection objective for this ecosystem component. Too often an IFN recommendation is made with no follow-up monitoring to measure if the desired effect has been achieved. This monitoring function may therefore be achieved through the use of information that is currently required, and will likely continue to be required in the future through the regulatory process.

\subsection{Biological Processes - Fish Habitat}

Numerous data gaps still remain for the fish component of the IFN study. Since office-based approaches to define an IFN designed to protect fish habitat are available and have been presented to the IFNTC (Tessmann evaluation), the other realistic option is to move forward with site-specific studies using a habitat modelling approach. However, there is a large amount of data required to conduct a fish habitat modelling study, most of which is not available for the Lesser Slave River. The main pieces of data required to complete a fish habitat modelling exercise are:

- Confirmation of the key fish species; 
- Information on the distribution and timing of key species and life stages;

- Habitat Suitability Curves (HSC) for the key species and life stages;

- Topographic and hydraulic data at representative study site(s) as input to the hydraulic and habitat model; and,

- Ice condition information for a winter modelling application.

\subsubsection{Key Fish Distribution and Timing}

A necessary initial step in the IFN process is to identify the key fish species for the analysis. Sufficient information appears to be currently available to facilitate this decision.

Regardless of the approach or tool used to evaluate fish habitat, information is needed to answer the seemingly straightforward questions of who is in the river, where are they and when are they there. For the Lesser Slave River, the answer to who is in the river is known but the where and when questions are not certain for the entire year or within each segment. In particular, confirmation of spawning habitats, overwintering habitats and summer movements are not certain for any of the key fish species identified. A detailed field program could be established to help answer these questions. Specific field studies that would be warranted in the upcoming year include:

- spring sampling to monitor for mountain whitefish and possibly lake whitefish fry drift in segments 1 and 2;

- spring sampling in the mainstem for walleye spawning in segments 1, 2 and 3, including electrofishing to find ripe adults and airlift or kick sampling to locate eggs and critical spawning habitats;

- $\quad$ spring sampling for northern pike eggs in the backwater habitats of Segment 4;

- summer inventory sampling along the entire length of the river using multiple gear types (electrofishing, seining, minnow traps) to identify summer distributions;

- fall sampling for mountain whitefish (and possibly lake whitefish) spawning including electrofishing and airlift or kick sampling to locate eggs and critical spawning habitats;

- late fall sampling (as close to ice up as possible) along the entire river to identify potential overwintering locations; and, 
- winter sampling using underwater video at suspected overwintering locations.

Without this information, an expert workshop, likely using the members from the IFNTC and other provincial and federal biologists, would be required to fill in the details of the species periodicity charts for each segment. In many cases, without strong evidence to show otherwise, most species and life stages would have to be included in most reaches and for most of the year. This would be done as a conservative measure to avoid the danger of not including a species or life stage and developing a flow recommendation that might have negative consequences on a species or life stage that was not evaluated. The downside of including all of the species at all times of the year is that it creates more data to deal with and interpret in the IFN evaluation step, and may result in a flow recommendation higher than necessary to protect a species or life stage not present within a segment or at a particular time of the year.

\subsubsection{Habitat Suitability Criteria}

In addition to the need for general fish distribution information, habitat suitability criteria (HSC) are needed for the Lesser Slave River to conduct the IFN evaluation. Development of sitespecific habitat suitability curves for all of the key species and life stages in the Lesser Slave River would likely be time cost prohibitive. An approach used recently in Alberta has relied on expert workshops to evaluate available habitat use data for a species from multiple sites and develop a generic HSC curve (Addley et al. 2003). This approach has been used to develop HSC curves for mountain whitefish, walleye and goldeye. An HSC curve has been developed for northern pike in the Battle River; however, success in transferring HSC results from one location to another has generally been poor in Alberta (Addley et al. 2003). It is recommended that some habitat use data be collected on the Lesser Slave River for all of the key management species, to validate any HSC curves developed through an expert workshop. Due to the large number of species potentially involved in the IFN analysis, a habitat guild approach may be appropriate which groups different species or life stages by the type of habitat they use (i.e., pools, riffles, runs) instead of developing HSC curves for each species individually. An expert workshop of regional fisheries biologists would be required to finalize the HSC curves. At that same workshop, the potential to use a mesohabitat or habitat guild approach in the IFN analysis could also be pursued. 
Methods for collecting habitat use data may be limited for the Lesser Slave River due to visibility issues. Snorkelling, the preferred method, might be possible in the spring under relatively clear and low-water conditions. The water colour and turbidity at other times of the year would likely make snorkelling ineffective. Pre-positioned electrofishing would be the next best alternative to snorkelling. The approach is time consuming; however, it provides a more accurate representation of the habitat used by fish prior to being sampled when compared to boat electrofishing results. The goal of the HSC data collection, which could also be done in the first year, would be to get as much data as possible (150 observation target per life stage) on as many species and life stages as possible to reduce the uncertainty in the expert workshop process.

Collecting habitat suitability criteria for the winter is an even more daunting task. Efforts to collect data from the Athabasca River have resulted in a large effort for relatively few results. On a large river like the Athabasca, telemetry proved to be the most effective method for locating fish under snow and ice cover. Underwater video has been successful in other stream and may be worth trying during the first winter prior to investing large amounts of money in a telemetry program. If a telemetry approach is chosen, monitoring should be continued for as long as possible to help answer some of the seasonal fish movement questions still remaining for the Lesser Slaver River.

\subsubsection{Selection of Study Sites}

Once fish distribution and timing issues have been addressed more completely and habitat suitability curves are in the process of being developed, study sites must be selected to collect topographic and hydraulic data for the purpose of conducting habitat modelling. It is often tempting to select study sites early in the process to expedite the study. However, without taking the necessary steps to ensure the study site locations are representative of habitat within the segment and critical habitats such as spawning and overwintering locations are captured, money and time can be wasted if a study site is placed in the wrong location and the results are not meaningful. Potential study sites have purposely not been identified in the report to avoid this situation.

To help define study site locations, identify potential spawning and overwintering habitats and provide supporting information for model development and calibration, it is recommended that 
high resolution, large scale aerial photography be taken of the river at low stage with good water visibility. From this data, a detailed habitat map of the entire river can be created. Study site locations could be selected based only on the habitat mapping results with best judgement used to identify potential overwintering and spawning habitats, although there is some risk in proceeding after this step without the support of the fisheries data identified earlier. If it is absolutely necessary to establish study sites in the upcoming year, it is strongly recommended that the habitat mapping information be used at a minimum and an expert workshop held in the presence of the IFNTC to achieve consensus on the site locations. The best option would be to wait until the following year after the fisheries studies are complete prior to establishing the study sites, to reduce the uncertainty in the process as much as possible.

Another tool that may be useful for the Lesser Slave River is to use thermal infra-red photography to identify potential thermal refugia along the river that may act as important overwintering locations. This should be collected in the fall as close to ice-up as possible to achieve the best potential for differentiating small thermal inputs. This information would help identify potential sites to conduct underwater video observations during the first winter.

\subsubsection{Data Collection for Model Input}

Once study site locations have been identified, data that define the bed topography and hydraulic characteristics of the site are required regardless of the model to be used. The data collection methods will vary depending on the type of model employed (i.e., a one-, two-, or threedimensional model). If winter conditions are to be included in the modelling effort, the only known tool currently capable of handling ice conditions that has a habitat component is the River2D model developed at the University of Alberta, although efforts in other jurisdiction may provide an alternate tool in the near future. If winter conditions will be addressed using an alternate approach, a one-dimensional model would remain an option, although some of the complex channel features such as large backwaters and islands would be better represented in a two-dimensional model.

Applying a habitat model in the winter adds additional cost and uncertainty to the process. Although a habitat modelling tool has been developed, it has not been applied and tested in a realworld situation. A large amount of effort is required to collect an additional set of topography 
data in the winter in combination with ice thickness information. The development of a stage discharge curve for the winter is an added challenge. Alternate approaches to under-ice modelling include doing an effective habitat analysis of fall spawning habitat versus a defined maximum reduction in habitat the following spring and assume that winter conditions in between are satisfied. This type of approach has been applied in Quebec and Alaska. The only other viable alternative is to use an office-based approach such as Tessmann to define winter flows and use a habitat model tool for the open-water period. This approach will generally result in conservative flow recommendations in the winter; however, the cost of conducting a winter study may make this option seem more reasonable.

An added complication to the model input is the definition of an ice cover to apply to the model if winter conditions are to be modelled. Ice conditions may vary from year to year depending on the flow and a number of other variables. Frazil ice may be present in the river that effects fish habitat as well as the applicability of the River2D model. Prior to conducting any winter modelling, some basic monitoring of ice processes would be warranted. Since dynamic ice processes may not be a big a concern on the Lesser Slave River, a scaled down version of the protocol outlined for the Athabasca River (Golder 2004) would likely be suitable. This would involve taking transect measurements of ice form down the entire length of the river as well as monitoring for frazil ice. Relying only on the data collected at the study site in the winter will limit the ability to estimate the ice form to be applied across the range of flow to be modelled. Monitoring for frazil ice is also important since deep pools identified by habitat mapping may turn out to be poor overwintering habitat if large amounts of frazil ice accumulate in these typically lower-velocity areas. The River2D model is also not set up to handle frazil ice conditions, and identifying the periods or extent of frazil ice will define the applicable period for model application. The ice monitoring program should continue for as many years as possible, preferably up to five years.

\subsubsection{Evaluation Approaches}

The end output from the habitat modelling is a weighted useable area (WUA) curve which defines the relationship between habitat conditions and flow based on the HSC data for each species or guild. No standard evaluation approach to define the IFN using the WUA curve has been defined. To incorporate the concepts of maintaining seasonal and yearly flow variability 
promoted by Annear et al. (2002), the approach used most recently in Alberta which relies on habitat time series evaluations (Clipperton et al. 2003) would be appropriate to meet these objectives. An extended period of naturalized flow is available for all segments of the Lesser Slaver River to allow for this type of evaluation to be possible. The application of WUA curves to evaluate an IFN is best limited over a range of flows where knowledge of fish habitat use is best understood. The range of flows where WUA curves are most applicable (typically up to the peak of the WUA curve) can vary widely between systems and species, but based on previous experience, are typically in the range of flows up to the mean annual flow. For species that spawn in floodplain areas, such as northern pike, this rule of thumb would not necessarily be applicable and WUA curves over a much higher range of flows could be developed. Floodplain spawning species have been evaluated in multiple studies in the United States, but have not been evaluated in previous IFN studies in Alberta.

\subsection{Connectivity}

Connectivity can be considered in terms of longitudinal and lateral connectivity. Longitudinal connectivity refers to the consideration of potential barriers to movement as a result of physical structures or changes in the flow or thermal regime of a river. Lateral connectivity refers to maintaining the connection of the mainstem with the floodplain.

Longitudinal connectivity would be a concern for the Lesser Slave River due to the presence of the weir at the outlet of the lake. Although two separate monitoring studies have been conducted, the ability of all fish species to move freely between the lake and the river cannot be stated with any certainty. Movements through the fishway during the fall have not been monitored. Some of the data would seem to suggest large numbers of individuals are present in the vicinity of the fishway but are not entering the structure. If this is the case, maintaining longitudinal connectivity may be more of a fishway design issue rather than a flow issue through the fishway.

Lateral connectivity in the Lesser Slave River would appear most critical in Segment 4 where the channel cutoffs were constructed. Flows that maintain a connection with these oxbows is considered to be critical as it provides substantial backwater habitat that is suspected to be used by northern pike for spawning and rearing, as well as providing potentially important habitat for wildlife and waterfowl. Since these oxbows are a main habitat feature of Segment 4 , the study 
site located in Segment 4 should incorporate the downstream end of an oxbow that is still connected to the main channel. Modelling flows to flood these oxbows should be sufficient to encapsulate the concept of lateral connectivity.

\subsection{Summary}

The overall IFN framework for the Lesser Slave River will most realistically be focussed over the range of flows defined by fish habitat, benthic invertebrate and water quality issues. The hydrology data is generally suitable in its current form to proceed with an IFN evaluation for these components, although some improvements to the data are possible. The higher range of flows that are considered important for channel morphology and riparian issues do not appear to be of immediate or foreseeable concern based on the current control structure and regulated flow regime in place. Although the channel is expected to continue adjusting within Segment 4 , the rate is very gradual and monitoring studies designed to predict the equilibrium bed morphology would be of a long-term nature. Incorporation of these components can be included at this stage in the IFN process with little additional effort based on the protocols described in Clipperton et al. (2003) and adjusted in the future if necessary based on more detailed information as it becomes available. Calculations of bed mobility can be used to define the channel morphology IFN. Measurements of bankfull conditions at the study sites and some additional air photo interpretation and basic field measurements may provide some insight on flows beneficial for the riparian ecosystem.

Existing monitoring data for both water quality and benthic invertebrates are sufficient to allow for an exploratory correlation analysis to be carried out. This approach would help identify parameters sensitive to changes in flow and could possibly be used to define an IFN value or may simply serve as a screening tool for the next step. Water quality models (CQUAL-W2 and WASP) have been set up for the Lesser Slave River and would be available for use if needed. The existing data for benthic invertebrates may be sufficient to develop habitat suitability criteria for depth and velocity if the initial screening suggests invertebrate populations show sensitivity to these variables.

Completing a fish habitat modelling study would require the most effort of any of the components. The available data are insufficient in several areas. General background data 
collection is recommended prior to beginning IFN data collection. The effort to collect HSC data is highly variable and depends on the time of year, species and life stage being sampled and can range from a few of days to collect more than enough data to hundreds of hours of effort and still have insufficient data. Background data obtained from habitat mapping using large scale, high resolution aerial photography and identification of potential overwintering locations using thermal infra-red photography are recommended prior to selecting study site locations. If possible, selection of study sites should be delayed until the second year of the study to allow the necessary background information to be collected. Confirming key species, species distribution and timing, development of HSC curves and identification of study sites could all be accomplished without any additional data collection for relatively low cost by using the members of the IFNTC and other provincial and federal agency biologists in an expert workshop setting. The pitfall of this approach is that the uncertainty in the process increases substantially and the study is open to criticism if all parties involved do not reach agreement.

A two-dimensional hydraulic modelling approach is recommended as it can more effectively simulate complex habitat features, such as backwater habitats or flow splits around islands. The River2D model also includes a river ice component that would allow for winter habitat modelling if desired. Evaluation of fish habitat should follow the habitat time series approach developed in Alberta (Clipperton 2003). 


\section{WORK PLAN AND BUDGET}

The work plan follows from the framework outlined in Section 5. Budgets provided are coarse estimates. Many steps within the process are directly linked to previous steps and predicting the effort to complete some tasks without going through the process is difficult. A summary of the work plan is provided in Table 19 and the budget summary is provided in Table 20.

\subsection{Hydrology}

The two main tasks identified for the hydrology component were to review of the naturalization results and extending the natural flows of the major tributaries to provide a longer period of record for each segment. These tasks could be completed at any time but should be done prior to conducting time series analysis or providing flow statistics to be used for calculating the IFN for other components. The level of effort would be approximately one person-week for each task (approximately $\$ 5,000$ each) assuming a regression approach could be used for extrapolating flows on the tributaries. If a modelling approach, such as the HSPF model, is required to extend the natural flow on the tributaries, a new model would have to be established and calibrated, which can take from 4-6 weeks $(\$ 20,000-\$ 30,000)$ to complete depending on data availability. Extending the naturalized flow could be done internally, but the review of the existing synthesized approach and results using the SSARR model are likely best if conducted by a third party reviewer.

\subsection{Channel Morphology}

No immediate field studies are needed for the channel morphology component. Application of an office approach as outlined in Clipperton et al. (2003) using data collected for other components is recommended and could be completed within AENV with a minimal level of effort. A longterm monitoring study designed to evaluate any continued channel change as a result of the weir would be beneficial, but the long duration of such a study and the limited information it would provide do not warrant this evaluation as a component of the IFN study. 


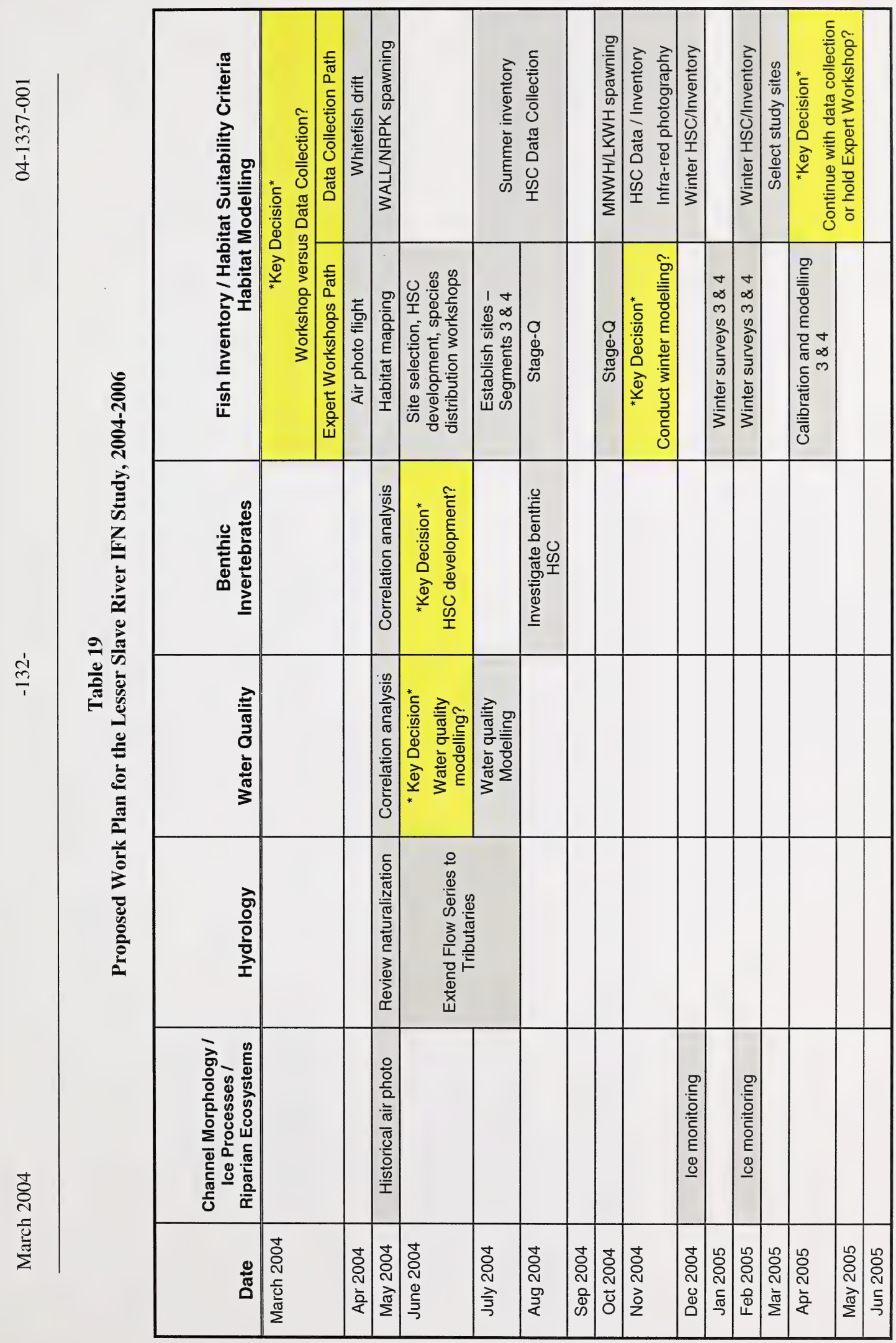




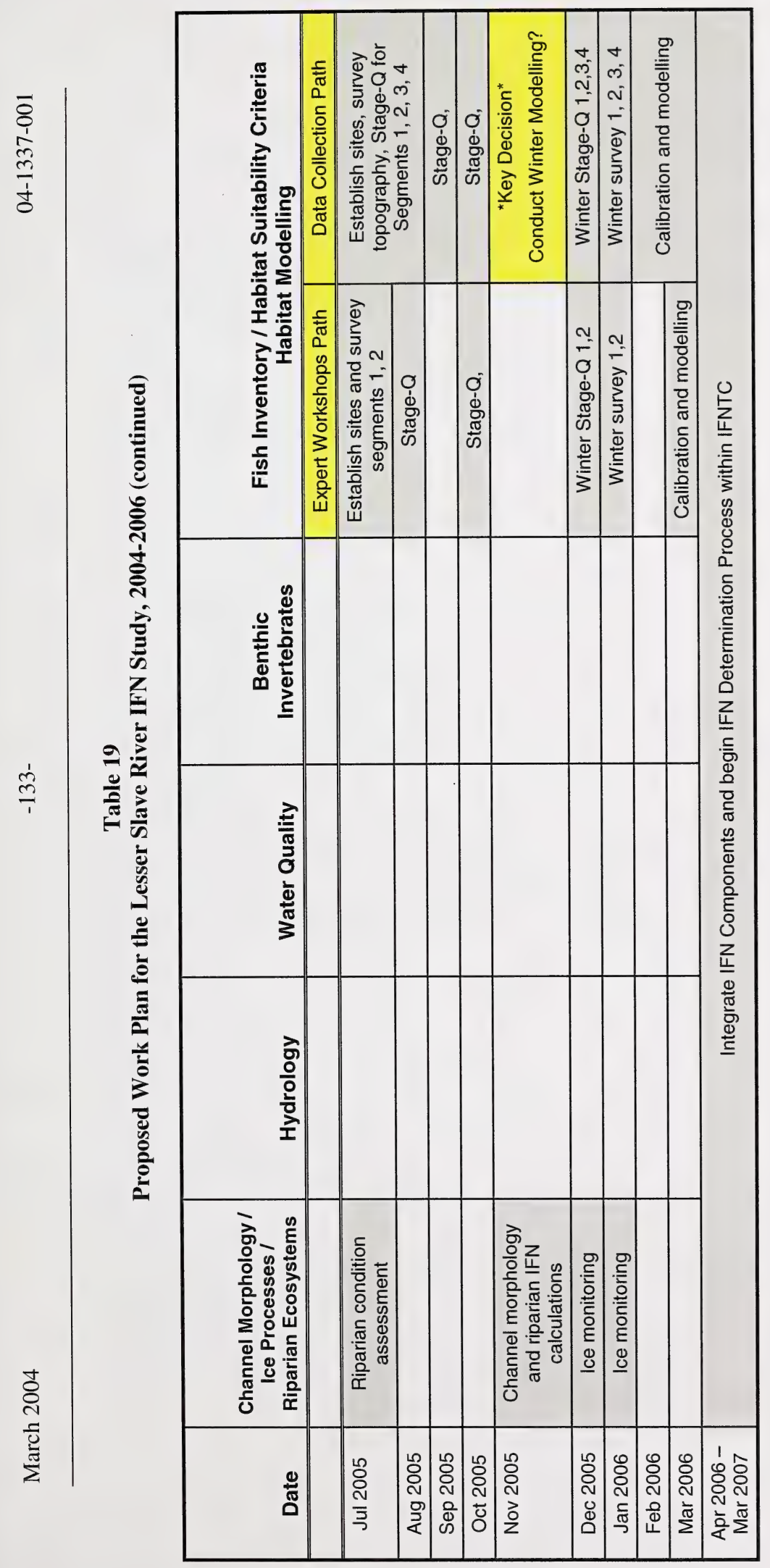

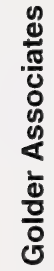




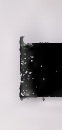

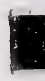

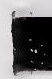

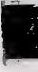

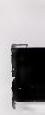

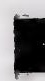

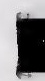

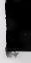

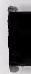

,

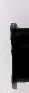

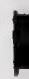

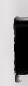

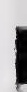

I

I

। 
Table 20

Proposed Budget Summary for the Lesser Slave River IFN Work Plan, 2004-2006

\begin{tabular}{|c|c|c|c|}
\hline Task & Timing & Duration & $\begin{array}{l}\text { Approximate } \\
\text { Cost }\end{array}$ \\
\hline \multicolumn{4}{|l|}{ Channel Morphology } \\
\hline Determine IFN from Shields Equation & $\begin{array}{l}\text { After fish habitat } \\
\text { surveys }\end{array}$ & 1 day & $\$ 1,000$ \\
\hline \multicolumn{4}{|l|}{ Riparian } \\
\hline Review historic air photos & May 2004 & 1 week & $\$ 5,000$ \\
\hline Evaluate riparian condition & July 2005 & 2 weeks & $\$ 10,000$ \\
\hline \multicolumn{4}{|l|}{ Hydrology } \\
\hline Review synthesized flow data & May 2004 & 1 week & $\$ 5,000$ \\
\hline Extend time series using regression & June 2004 & 1 week & $\$ 5,000$ \\
\hline Set up new model for naturalization & June-July 2004 & 4-6 weeks & $\$ 30,000$ \\
\hline \multicolumn{4}{|l|}{ Water Quality } \\
\hline $\begin{array}{l}\text { Conduct exploratory analysis (including data } \\
\text { entry of raw data) }\end{array}$ & May 2004 & 2 weeks & $\$ 10,000$ \\
\hline $\begin{array}{l}\text { Set up water quality model (if needed } \\
\text { assuming no additional data) }\end{array}$ & June-July 2004 & 4 weeks & $\$ 20,000$ \\
\hline Collect additional data & TBD & TBD & TBD \\
\hline \multicolumn{4}{|l|}{ Benthic Invertebrates } \\
\hline $\begin{array}{l}\text { Conduct exploratory analysis (including data } \\
\text { entry of raw data) }\end{array}$ & May 2004 & 2 weeks & $\$ 10,000$ \\
\hline Develop HSC using existing data (if possible) & $\begin{array}{l}\text { After exploratory } \\
\text { analysis }\end{array}$ & 1 week & $\$ 5000$ \\
\hline Collect additional data & TBD & TBD & TBD \\
\hline \multicolumn{4}{|l|}{ Habitat Mapping } \\
\hline $\begin{array}{l}\text { High resolution aerial photography } \\
\text { (orthorectified) }\end{array}$ & April 2004 & & $\$ 20,000$ \\
\hline Habitat delineation & May 2004 & 1 week & $\$ 5,000$ \\
\hline Thermal infra-red photography & November 2004 & & $\$ 3,000$ \\
\hline \multicolumn{4}{|l|}{ Fish Species Distribution } \\
\hline Spring Inventory & April-May & 6 weeks & $\$ 95,000$ \\
\hline Summer Inventory & July-August & 2 weeks & $\$ 45,000$ \\
\hline Fall Inventory & October-November & 2 weeks & $\$ 35,000$ \\
\hline Winter Inventory & December/February & 3 weeks & $\$ 35,000$ \\
\hline Expert Workshop & $\begin{array}{l}\text { Anytime after data } \\
\text { collection }\end{array}$ & $1-2$ days & $\begin{array}{l}\text { Participant } \\
\text { Dependant }\end{array}$ \\
\hline
\end{tabular}


Table 20

Proposed Budget Summary for the Lesser Slave River IFN Work Plan, 2004-2006 (continued)

\begin{tabular}{|c|c|c|c|}
\hline Task & Timing & Duration & $\begin{array}{l}\text { Approximate } \\
\text { Cost }\end{array}$ \\
\hline \multicolumn{4}{|l|}{ Develop HSC Curves } \\
\hline $\begin{array}{l}\text { Collect data (Open-water, cost reduced } \\
\text { combined with inventory for savings }\end{array}$ & $\begin{array}{l}\text { All seasons (in } \\
\text { combination with } \\
\text { inventory) }\end{array}$ & 2 weeks & $\$ 20,000$ \\
\hline Collect data (Winter) & December/February & 3 weeks & $\begin{array}{l}\text { Incl. winter } \\
\text { inventory }\end{array}$ \\
\hline Data analysis & $\begin{array}{l}\text { Immediately after data } \\
\text { collection }\end{array}$ & 1 week & $\$ 5,000$ \\
\hline Expert Workshop & $\begin{array}{l}\text { Anytime after data } \\
\text { collection }\end{array}$ & $1-2$ days & $\begin{array}{l}\text { Participant } \\
\text { dependant }\end{array}$ \\
\hline Telemetry program & Assess after first winter & & $\begin{array}{r}>\$ 100,000 \text { per } \\
\text { year }\end{array}$ \\
\hline \multicolumn{4}{|l|}{ Hydraulic Modelling } \\
\hline $\begin{array}{l}\text { Study site selection, open water survey, } \\
\text { stage-discharge, calibration }\end{array}$ & $\begin{array}{l}\text { Descending limb of } \\
\text { hydrograph (2005) }\end{array}$ & $\begin{array}{l}3 \text { weeks per } \\
\text { site }\end{array}$ & $\$ 50,000 /$ site \\
\hline Under ice survey, stage-discharge, calibration & $\begin{array}{l}\text { Winter following open- } \\
\text { water survey }\end{array}$ & $\begin{array}{l}3 \text { weeks per } \\
\text { site }\end{array}$ & $\$ 50,000 /$ site \\
\hline \multicolumn{4}{|l|}{ IFN Development } \\
\hline $\begin{array}{l}\text { Integrate IFN results using established } \\
\text { protocols }\end{array}$ & After all data collection & 3 weeks & $\$ 15,000$ \\
\hline
\end{tabular}

\subsection{Water Quality}

The first course of action for the water quality component would be to conduct an exploratory correlation analysis of the water quality data with flow. The time required to sort through the existing data, enter raw data from other sources and conduct the analysis is estimated to be about two person-weeks of effort (approximately $\$ 10,000$ ). This task could proceed immediately with the data currently available or wait until the most recent EEM data are available. A key decision point should be identified once these initial results are available. The correlation analysis might provide a suitable tool to identify the range of flows that become critical for water quality or at the very least identify what parameters are most sensitive to flow to carry forward to any water quality modelling phase. Identifying additional water quality data requirements and proposing a field study would be premature at this point in the scoping process. It is recommended that an 
updated workplan be created that identifies any additional field effort, if necessary, be developed after the outcome of the exploratory analysis is available.

AENV has established a water quality model on the Lesser Slave River. The current status of the model has not been assessed and estimating the level of effort to conduct the modelling without knowing the state of the model is difficult. Based on previous experience using the CQUAL-W2 model, it can require four person-weeks of effort $(\$ 20,000)$ to calibrate and run the model assuming no addition field measurements are required. Since AENV has staff with modelling capabilities, this task may be conducted internally for little cost to the IFNTC.

\subsection{Benthic Invertebrates}

The first course of action for the benthos component would be to conduct an exploratory correlation analysis of the benthos data with flow, depth and velocity. The time required to sort through the existing data, enter raw data from other sources and conduct the analysis is estimated to be about two person-weeks of effort (approximately $\$ 10,000$ ). This task could proceed immediately with the data currently available or wait until the most recent EEM data are available. The product from this task may result in a flow relationship with a key invertebrate population parameter that could be used to define an IFN flow target. A key decision point should be identified once these initial results are available. There is the potential that additional effort could be placed on developing HSC for invertebrate communities, if the results indicate a relationship with either depth or velocity. Developing HSC for benthic communities would require about one week of effort (approximately \$5000) using existing data. The HSC could then be applied with the fish HSC data as a component of habitat modelling. Identifying additional benthos data requirements and proposing a field study would be premature at this point in the scoping process. It is recommended that an updated workplan be created that identifies any additional field effort, if necessary, be developed after the outcome of the exploratory analysis is available.

\subsection{Riparian Ecosystems}

Two main tasks were identified for including riparian ecosystems in the IFN study. Conducting a more detailed historical time series review of air photos to determine historic channel migration 
rates and riparian development (approximately \$5000) and collecting some basic field data on community structure, age, recruitment locations and causes of observed tree stress (about $\$ 10000$ ) may help to identify functioning within the system and potentially clarify the influence of flow on the riparian community. If flow is not a key driver, then there is the potential to remove this component from the IFN study, although thought should still be given to protecting the riparian ecosystem as an integral component of the aquatic ecosystem. Assuming a field component is pursued to collect topography data for use in fish habitat modelling; ensuring the field survey extends into the riparian floodplain would provide some basic information to evaluate the riparian component with limited additional costs.

\subsection{Fish Habitat}

\subsubsection{Fish Distribution and Timing}

It is necessary to finalize the fish distribution and timing of different life stages for the Lesser Slave River. The approach used to complete this task could be entirely through an expert workshop of government biologists at virtually no cost to the IFNTC. This workshop, in combination with an HSC workshop (discussed later) could be expected to last three days, with considerable up front effort to organize the workshop. If outside experts are expected to participate, expense, travel costs and remuneration costs can be anticipated to be on the order of $\$ 10,000$ - $\$ 20,000$, depending on who attends. If no additional data are collected, the need for outside expertise and a larger workshop would increase, to obtain information from the largest knowledge base possible.

If additional data are collected and a good information base is available, it is likely the workshop could be carried out with government staff and result in virtually no out-of-pocket cost to the IFNTC. In either case, with or without additional site-specific data, a workshop will be required to fill in the few remaining gaps to allow the process to continue. Not collecting any additional site-specific data will result in the highest level of uncertainty, the need to be conservative in many of the assumptions, and possibly the rejection of study results by stakeholder(s) if dissatisfaction with the study outcome exists, but this can be a valid approach if all of the interested stakeholders are in agreement with the process. 
Conducting additional inventory and spawning information is recommended to reduce uncertainty in developing the species distribution tables. Spring work should include a larval drift survey for whitefish fry in Segments 1 and 2. The drift study should last for about one month to capture the peak of the drift and should begin right after ice-out in April. The nets would have to be checked twice per day, so this would be a labour intensive study (approximately \$60,000). If a simple confirmation of larval presence is required without details on peak timing, an abbreviated study may suffice.

Additional spring boat electrofishing surveys in the lower segments to look for ripe walleye, and airlift and kick sampling for eggs could overlap with some of the whitefish fry drift study. The walleye study would likely not begin until later April and continue into May. Two electrofishing passes of the lower $40 \mathrm{~km}$ ( 3 days each) of river and a single pass to collect eggs (4 days) would be recommended to identify spawning areas (approximately $\$ 35,000$ ). If both the whitefish drift and walleye spawning studies were combined, there would be cost saving due to the overlap of programs and savings on travel time.

Additional spring work that would be useful would be to confirm the presence of northern pike eggs in the backwaters located in Segment 4. Ripe adults have already been found in the segment, but confirmation that spawning is taking place would be useful to identify potential study site locations. This would likely require a few days of effort in May and June and may best be conducted by the Fish and Wildlife office in Slave Lake. The identification of egg incubation and early rearing habitat by northern pike would also be important information in developing the IFN, as maintenance of marshy areas (i.e., maintaining stage) during these life stages can be critical for good recruitment subsequent to spawning.

Summer sampling within all segments is recommended. A multi-gear sampling program at one site within each segment would fill a large data gap. A possible approach would be to spend two days at each site to allow for multiple sampling methods to be used in an attempt to catch fry, juvenile and adult life stages. Sampling should occur in July and August to cover the summer period (approximately $\$ 45,000$ ). 
Fall sampling for whitefish spawning would follow a similar program to the walleye spring spawning program, and consist of electrofishing for adults, and airlift and kick sampling for eggs (approximately $\$ 35,000$ ).

\subsubsection{Habitat Suitability Criteria - Open Water}

Collecting site-specific HSC data is recommended. The time required to develop a full set of site-specific data is difficult to estimate due to a wide number of variables that can affect sampling efficiency. A general rule of thumb to determine the sample size necessary to develop site specific HSC curves is to target 150-200 observations per life stage of interest (Bovee 1986). This is a simple guideline and more or less observations may be required. An attempt to collect snorkelling data in the spring may be possible, but visibility at other times of the year is likely too poor. Collection of HSC data could be included with any of the other studies mentioned above, with an added cost of a few extra days of field effort and some additional data analysis time. Done on its own, a minimum of two weeks of additional effort $(\$ 15,000-\$ 20,000)$ would likely be required to get some good data to feed into the workshop. Final costs would be highly variable and dictated by the sampling strategy employed and potential efficiencies by including this effort with the inventory effort. At the end of the first year of data collection, an assessment of efficiency in data collection can be made and a decision would be required as to whether to continue with additional data collection in year two or if the existing data is sufficient to hold a workshop to finalize the HSC curves to be used.

\subsubsection{Winter Sampling}

It is recommended that some preliminary winter sampling be conducted to document ice conditions along the river and investigate overwintering use by fish using underwater video. The ice monitoring would also investigate the presence of frazil ice within the Lesser Slave River. Approximate cost assuming three separate one week field visits, would be approximately $\$ 35,000$. At this time, some preliminary data on fish habitat use for the development of winter HSC data could be collected. An assessment of the efficiency of under ice data collection using passive techniques such as underwater video would provide insight on effort required for additional winter measurements and if a telemetry program is necessary. Conducting winter telemetry can be very expensive, based on previous experience on the Athabasca River 
(R.L.\&L./Golder 2003) and would likely cost in the order of $\$ 100,000$ or greater per year depending on the level of effort and number of radio tags employed.

The winter IFN approach currently under development for the Athabasca River may be applicable for the Lesser Slave River if a modelling approach is desired; however, the protocol for evaluating habitat conditions in the winter to derive an IFN has not been developed and was not a component of the approach outlined in South Saskatchewan River Basin. Alternate approaches in the winter months, such as applying office-based evaluations or potentially adapting a fall spawning approach, remain a possibility and may be more cost effective than under-ice modelling; however, these approaches would have to be developed by the IFNTC as part of the IFN program since a standard winter approach (other than Tessmann) has not been established for Alberta.

\subsubsection{Habitat Mapping and Thermal Infra-red Photography}

Habitat mapping is recommended to occur as soon as possible and prior to establishing study site locations. The thermal infra-red is recommended if a winter modelling component is to be included in the IFN assessment. They require a minimal amount of effort but provide substantial benefit to the project. Costs of collecting this data will be dependent on the local availability of the necessary technology for the high resolution air photo and thermal infra-red photography. Aerial photography at a scale of 1:10000 would cost approximately $\$ 7500$ and to create orthophotos would bring the total cost up to approximately $\$ 20000$. Thermal infra-red video is available locally and could be flown for approximately $\$ 3000$. The air photos should be timed early in the spring at a low river stage with the water as clear as possible. The thermal infra-red should be flown as close to ice-up as possible in the fall. Both of these tasks should be done in 2004. Interpretation of the data and the development of a habitat map should require about a person-week of effort (approximately $\$ 5000$ ).

\subsection{Two-dimensional Modelling}

The time to collect the field data to run a two-dimensional model will vary depending on the size of the study site, ease of access and survey conditions. An approximation of the time to conduct an open-water survey would be on the order of 10 days to collect the topography data, 5 days for 
data entry and calibration, and the costs to develop a stage-discharge curve, which may be in the order of $\$ 40,000$ to $\$ 50,000$ per site. The cost to collect the additional winter data for each site would increase this estimated cost to the range of $\$ 100,000$ per site for both a summer and winter survey. These costs are estimates only, and the actual cost will be directly proportional to the size of the study sites that will be identified.

\subsection{IFN Evaluations}

The IFN evaluation would typically follow two steps; the technical development of an IFN determination following the approach outlined in Clipperton et al. (2003) and the development of an IFN recommendation to be incorporated into water management planning. The first step provides the tool to evaluate the current status of flow regulation with respect to the IFN and the relative change in the IFN with different management options. Using the approach outlined in Clipperton et al. (2003), the integration of all of the ecosystem components would require approximately three person-weeks $(\$ 15,000)$ to conduct the final IFN evaluations for each component and create an integrated IFN for all of the segments. The second step to determine the recommended IFN is often a lengthy process and would be conducted primarily within the IFNTC. Previous experience would indicate that this step in the process can last for several years. 


\section{CONCLUSIONS}

In general, data on the Lesser Slave River is sufficient to develop an IFN within two to three years that incorporates multiple ecosystem components into the final IFN recommendation. Channel morphology and riparian ecosystems do not appear to be a major concern at this point but can be incorporated into the IFN using fairly simple calculations from data collected at the habitat modelling sites. The existing monitoring data for water quality and benthic invertebrates are sufficient to conduct exploratory correlation analyses to determine if there are any flow sensitive parameters. This information may be suitable to develop an IFN recommendation or a decision would have to be made to investigate more detailed approaches.

The availability of data to complete a fish habitat modelling study to incorporate into the IFN recommendation is poor. General fisheries data are lacking to define the distribution of key fish species, once these key species have been determined. A series of fisheries studies have been recommended to fill in some of the major data gaps including identifying spawning and overwintering locations on the Lesser Slaver River. In addition, habitat mapping and thermal infra-red information are needed prior to selecting study sites for habitat modelling. The timing of data collection for input into the River2D model should not commence until the 2005 season to allow for all of the necessary background information to be collected to facilitate optimal study site selection. If the collection of additional biological data is not pursued, a series of expert workshops will be required to fill in the data gaps. The workshops would be cost effective; however, they add uncertainty to the process. The uncertainty from the lack of site-specific data may be acceptable if all interested parties agree to the process, and the potential limitations of the process, prior to beginning the process.

Final evaluation of the IFN would be left up to the IFNTC. Data from each component would be incorporated into a unified IFN flow regime using a process similar to that completed for the South Saskatchewan River Basin IFN study. Even with an expedited schedule, a final IFN recommendation would not likely be available any earlier than 2006, if any habitat modelling is conducted, and perhaps later if winter habitat modelling is included in the program. 

March 2004

$-143-$

04-1337-001

8. CLOSURE

We trust the above meets your present requirements. If you have any questions or require additional details, please contact the undersigned.

FOLDER ASSOCIATES LTD.

Report prepared by:

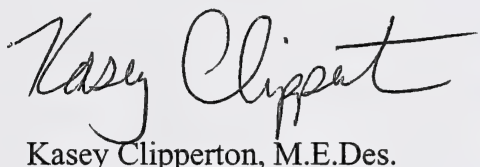

Fisheries Biologist
Report reviewed by:

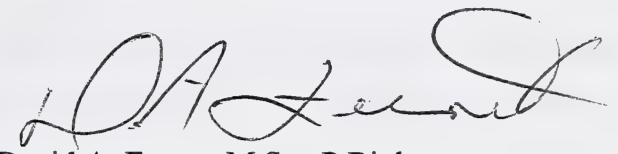

David A. Fernet, M.Sc., P.Biol.

Principal

Golden Associates 


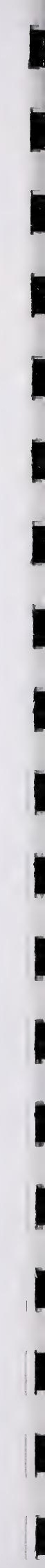




\section{REFERENCES}

\section{Information Sources for Sections 1, 2, 3, 5 and 6}

Addley, R.C., G.K. Clipperton, T.B. Hardy, and A.G.H. Locke. 2003. Fish habitat suitability criteria (HSC) curves: South Saskatchewan River Basin, Alberta, Canada. Prepared for Alberta Sustainable Resource Development, Cochrane, AB.

Alfredsen, K. and E. Tesaker. 2002. Winter habitat assessment strategies and incorporation of winter habitat in the Norwegian habitat assessment tools. Hydrological Processes 16:927-936.

Annear, T.C., I. Chisholm, H. Beecher, A. Locke, and 12 other authors. 2002. Instream flows for riverine resource stewardship. Published by the Instream Flow Council, Cheyenne, WY.02

Ashton, G.D. 1990. Ice effects on hydraulics and fish habitat. U.S. Army Corps of Engineers, CCREL Report 90-8.

Arthington, A.H., J.M. King, J.H. O'Keeffe, S.E. Bunn, J.A. Day, B.J. Pusey, D.R. Bluhdorn, and R. Tharme. 1991. Development of an holistic approach for assessing environmental flow requirements for riverine ecosystems. in: Water allocation for the environment: Proceedings of an international seminar and workshop, November 27-29, 1991. J.J. Pigram and B.P. Hopper [eds.] The Centre for Water Policy Research, University of New England, Armidale, New South Wales, Australia. pp. 66-76.

Bain, M.B., Finn, J.T., and H.E. Booke. 1988. Streamflow regulation and fish community structure. Ecology 69(2): 382-392.

Belzile, L., P. Berube, V.D. Hoang et M. Leclerc. 1997. Méthode écohydrologique de détermination des débits réservés pour la protection des habitats du poisson dans les rivières du Québec. Rapport présenté par le Groupe conseil Génivar et l'INRS-Eau au ministère de l'Environnement et de la Faune et à Pêches et Océans Canada. 83 p. +8 annexes. 
Bendock, T. N. and A. E. Bingham. 1988. Feasibility of estimating winter distribution and habitat preference for juvenile salmonids in the mainstem Kenai River, Alaska, 19861987. Alaska Department of Fish and Game, Fishery Data Series No. 38, Juneau, Alaska, USA.

Bovee, K.D. 1982. A guide to stream habitat analysis using the instream flow incremental methodology. Western Energy and Land Use Team, Office of Biological Services, Fish and Wildlife Service, U.S. Dept. of the Interior, Washington, D.C. Instream Flow Information Paper 12. 248pp.

Bovee, K.D. 1986. Development and evaluation of habitat suitability criteria for use in the instream flow incremental methodology. Instream Flow and Aquatic Systems Group, U.S. Fish and Wildlife Service, U.S. Dept. of the Interior, Washington, D.C. Instream Flow Information Paper No. 21.

Bovee, K.D., B.L. Lamb, J.M. Bartholow, C.D. Stalnaker, J. Taylor, and J. Henriksen. 1998. Stream habitat analysis using the Instream Flow Incremental Methodology. U.S. Geological Survey, Biological Resources Division, Information and Technical Report USGS/BRD-1998-0004. 131p.

Brown, C. and J. King. 2002. Breede River basin study DRIFT application. Prepared for the Department of Water Affairs and Forestry, South Africa 66p. + appendices. www.southernwaters.co.za

Clipperton, G.K., R.F. Courtney, T.S. Hardin, A.G.H. Locke, and G.L. Walder. 2002. Highwood River instream flow needs technical working group final report. Alberta Transportation, Edmonton.

Clipperton, G.K., C.W. Koning, A.G.H. Locke, J.M. Mahoney and B. Quazi. 2003. Instream Flow Needs Determinations for the South Saskatchewan River Basin, Alberta, Canada. Alberta Environment, Edmonton AB.

Cunjak, R.A. 1996. Winter habitat of selected stream fishes and potential impacts from land-use activity. Canadian Journal of Fisheries and Aquatic Sciences 55(Supp. 1): 267-282. 
DeCicco, A. L. 2001. Over-wintering areas used by Dolly Varden in the Nome, Solomon, and Bonanza rivers, Seward Peninsula, Alaska 2000/2001. Alaska Department of Fish and Game, Fishery Data Series No. 01-25, Anchorage.

Estes, C.C. 1998. Annual summary of instream flow reservations and protection in Alaska. Alaska Department of Fish and Game.

Golder (Golder Associates td.). 2000. Continuous modelling of winter dissolved oxygen concentrations in the Athabasca River from Hinton to upstream of grand rapids: 2000 update. Prepared for Alberta Forest Products Association.

Golder (Golder Associates td.). 2004. DRAFT REPORT - Athabasca River Instream Flow Needs Scoping Study. Prepared for CEMA, Ft. McMurray, AB.

Hardy, T.B. 2000. A conceptual framework and technical approach for assessing instream flow needs in the Water Resource Inventory Area No. 1 (WRIA1) in Washington State (Final Draft). Utah State University, Logan, UT. 64p.

Hardy, T.B. and C. Addley. 2001. Evaluation of Interim Instream Flow Needs in the Klamath River, Phase II. Institute for Natural Systems Engineering, Utah Water Research Laboratory, Utah State University, Logan, Utah. 84322-8200.

Independent Scientific Group. 2000. Return to the river. Northwest Power Planning Council, Report 2000-12. 536p.

Johnson, L.S., T.A. Wesche, D.L. Wichers and J.A. Gore. 1982. Instream salmonid habitat exclusion by ice-cover. Water Resources Research Institute, University of Wyoming. Water Resources Series No. 84.KGS (KGS Group). 2001. Overview of Numerical Hydraulic Models of River Ice Conditions and Description of River ice Processes. Prepared for CEMA, Fort McMurray, Ab.

Lubinski. B.R. 2000. Use of Ground Surveys to Validate Aerial Telemetry Data on Arctic Grayling in J. H. Eiler, D. J. Alcorn, and M. R. Neuman (editors). Biotelemetry 15: Proceeding of the $15^{\text {th }}$ International Symposium on Biotelemetry. Juneau, Alaska USA. International Society on Biotelemetry. Wageningen, The Netherlands. 
Maki-Petays, A., T. Muotka, and A. Huusko. 1999. Densities of juvenile brown trout in two subarctic rivers: Assessing the predictive capability of habitat preference indices. Canadian Journal of Fisheries and Aquatic Sciences 56:1420-1427.

McGurk, B.J. and B.A. Paulson. 2002. Developing streamflow recommendations: Tools that work. Hydro Review October 2002.

Muth, R.T., L.W. Crist, K.E. LaGory, J.W. Hayse, K.R. Bestgen, T.P. Ryan, J.K. Lyons, and R.A. Valdez. 2000. Flow and temperature recommendations for endangered fishes in the Green River downstream of Flaming Gorge dam. Upper Colorado River Endangered Fish Recovery Program Project FG-53. www.ead.anl.gov/pub/index.cfm

Poff, N.L., J.D. Allan, M.B. Bain, J.R. Karr, K.L. Pretegaard, B.D. Richter, R.E. Sparks and J.C. Stromberg. 1997. The natural flow regime: a paradigm for river conservation and restoration. BioScience 47(11):769-784.

Richter, B.D., J.V. Baumgartner, J. Powell and D.P. Braun. 1996. A method for assessing hydrologic alteration within ecosystems. Conservation Biology 10: 1163-1174.

RL\&L/Golder (RL\&L Environmental Services Ltd./Golder Associates Ltd.). 2003. Fish overwintering use of the lower Athabasca River 2001 to 2003. Prepared for CEMA Water Working Group. Report No. 012-7014.

Seneka, M. 2000. Lesser Slave River at Slave Lake low flow frequency analysis. Water Sciences Branch, Hydrology/Forecasting Section Report 7BJ, 2000-119. Alberta Environment.

Solazzi, M. F., T. E. Nickelson, S. L. Johnson, and J. D. Rodgers. 2000. Effects of increasing winter rearing habitat on abundance of salmonids in two coastal Oregon streams. Canadian Journal of Fisheries and Aquatic Sciences 57: 906-914.

Tennant, D.L. 1976. Instream flow regimens for fish, wildlife, recreation, and related environmental resources. Fisheries 1(4):6-10.

Tessmann, S.A. 1979. Environmental assessment. in: Reconnaissance Elements of The Western Dakotas Region of South Dakota Study, Technical Appendix E. Water Resources Research Institute, South Dakota University. 
U.S. Fish and Wildlife Service (USFWS) and Hoopa Valley Tribe. 1999. Trinity River flow evaluation: Final report. Prepared for U.S. Department of the Interior, Washington D.C. 308p. +App.

Walder, G.L. 1996. Northern River Basins Study project report No. 66, Proceedings of the Northern River Basins Study instream flow needs workshop, October 14-15, 1993 and January 6-7, 1994, Northern River Basins Study, Edmonton, Alberta.

Whalen, K.G., D.L. Parrish, and M.E. Mather. 1999. Effect of ice formation on selection of habitats and winter distribution of post-young-of-the-year Atlantic salmon parr. Canadian Journal of Fisheries and Aquatic Sciences 56:87-96.

Zafft, D. J., P. Braaten, K. Johnson, and T. Annear. 1995. Comprehensive study of the Green River fishery between the New Fork River Confluence and Flaming Gorge Reservoir, 1991-1994. Completion Report. Wyoming Game and Fish Department, Cheyenne.

\section{Information Sources for Section 4.2 - Channel Morphology and Ice Processes}

Alberta Environment. 1993. Lesser Slave Lake Regulation - Status Report.

Alberta Environment. 1994. An Evaluation of As-Constructed Works below Lesser Slave Lake Outlet.

Alberta Environment. 1996. Lesser Slave River Cutoffs Assessment - Summary Notes on River Channel Cross Sections.

Alberta Environment. 2000. Lesser Slave Lake Regulation Information Update.

Kellerhals, R., Neill, C.R., and Bray, D.I. 1972. Hydraulic and Geomorphic Characteristics of Rivers in Alberta. Research Council of Alberta, River Engineering Report 72-1.

Northwest Hydraulic Consultants Ltd. 1980. Ice Regimes, Lesser Slave Lake and River (Memorandum). 
Northwest Hydraulic Consultants Ltd. 1984. An Assessment of Impact of Cutoffs and Weir on River Regime, and Recommended Monitoring Program - Lesser Slave River Below Lesser Slave Lake Outlet.

\section{Information Sources for Section 4.3 - Water Quality}

Alberta Environment (AENV). 1999. Surface Water Quality Guidelines for Use in Alberta. November 1999. Environmental Science, Environmental Sciences Division. Edmonton, AB.

Alberta Environment (AENV). 2000. Low Flow Conditions in the Lesser Slave River, 1999. 2000. Water Sciences Branch, Water Management Division, Natural Resource Services, Edmonton, Alberta.

CCME (Canadian Council of Ministers of the Environment). 1999. Canadian Environmental Quality Guidelines. Winnipeg, MB.

E.V.S. Consultants Ltd. (EVS). 1990. Baseline Environmental Studies of the Lesser Slave River, Volume I: Final Report. Prepared for Slave Lake Pulp Corporation, Slave Lake, Alberta.

EVS. 1991. Baseline Environmental Studies of the Lesser Slave River, Volume II: Final Report. Prepared for Slave Lake Pulp Corporation, Slave Lake, Alberta.

EVS. 1992a. 1991 Operational Monitoring of the Lesser Slave River, Volume III: Final Report. Prepared for Slave Lake Pulp Corporation, Slave Lake, Alberta.

EVS. 1992b. 1992 Operational Monitoring of the Lesser Slave River, Volume IV: Final Report. Prepared for Slave Lake Pulp Corporation, Slave Lake, Alberta.

EVS. 1992c. 1992 Operational Winter Water Quality Monitoring on the Lesser Slave River, Draft Report. Prepared for Slave Lake Pulp Corporation, Slave Lake, Alberta.

EVS. 1993. 1993 Operational Winter Water Quality Monitoring on the Lesser Slave River, Draft Report. Prepared for Slave Lake Pulp Corporation, Slave Lake, Alberta. 
EVS. 1994. 1994 Operational Winter Water Quality Monitoring on the Lesser Slave River, Draft Report. Prepared for Slave Lake Pulp Corporation, Slave Lake, Alberta.

EVS. 1995a. 1993 Operational Monitoring of the Lesser Slave River, Volume V: Final Report. Prepared for Slave Lake Pulp Corporation, Slave Lake, Alberta.

EVS. 1995b. 1994 Operational Monitoring of the Lesser Slave River, Draft Report. Prepared for Slave Lake Pulp Corporation, Slave Lake, Alberta.

EVS. 1995c. 1995 Operational Winter Water Quality Monitoring on the Lesser Slave River, Draft Report. Prepared for Slave Lake Pulp Corporation, Slave Lake, Alberta.

EVS. 1996a. 1995 Operational Monitoring of the Lesser Slave River, Draft Report. Prepared for Slave Lake Pulp Corporation, Slave Lake, Alberta.

EVS. 1996b. Lesser Slave River Environmental Effects Monitoring-First Cycle Interpretive Report, Draft Report. Prepared for Slave Lake Pulp Corporation, Slave Lake, Alberta.

Golder Associates Ltd. (Golder). 2003. Oil Sands Regional Aquatics Monitoring Program (RAMP). Five Year Report Prepared for the RAMP Steering Committee. Calgary, Alberta.

Stantec Consulting Ltd. (Stantec) and Golder Associates Ltd (Golder). 1999a. Cycle 2 Environmental Effects Monitoring, Athabasca River Basin Pulp Mills. Volume I: Interpretive Report. Prepared for Weldwood of Canada Ltd., Hinton, Alberta; Alberta Newsprint Company, Whitecourt, Alberta; Millar Western Forest Products Ltd., Whitecourt, Alberta; Slave Lake Pulp, Slave Lake, Alberta; Alberta-Pacific Forest Industries Inc., Boyle, Alberta.

Stantec and Golder. 1999b. Cycle 2 Environmental Effects Monitoring, Athabasca River Basin Pulp Mills. Volume II: Appendix. Prepared for Weldwood of Canada Ltd., Hinton, Alberta; Alberta Newsprint Company, Whitecourt, Alberta; Millar Western Forest Products Ltd., Whitecourt, Alberta; Slave Lake Pulp, Slave Lake, Alberta; AlbertaPacific Forest Industries Inc., Boyle, Alberta. 
Taylor, B.R. and B.A. Barton. 1992. Temperature and dissolved oxygen criteria for Alberta fishes in flowing water. Prepared by Environmental Management Associates, Calgary. Prepared for Alberta Fish and Wildlife Division, Edmonton.

U.S.EPA (United States Environmental Protection Agency). 1999a. National Recommended Water Quality Criteria - Correction. Office of Water. April 1999. U.S.EPA 822-Z-99001.

U.S.EPA. 1999b. Update of Ambient Water Quality Criteria for Ammonia. Office of Water. April 1999. U.S.EPA 822-R-99-014. Alberta Environment (AENV). 2003. Water Data System (electronic database). Environmental Quality Monitoring Branch, Environmental Assessment Division, Environmental Protection Services, Edmonton, Alberta.

\section{Information Sources for Section 4.4 - Benthic Invertebrates}

Environment Canada. 1998. Pulp and Paper Technical Guidance Document for Aquatic Environmental Effects Monitoring. EEM/1998/1, April 1998. Environment Canada. Ottawa, ON.

EVS Consultants Ltd. (EVS). 1990. Baseline Environmental Studies of the Lesser Slave River, Volume I: Final Report. Prepared for Slave Lake Pulp Corporation, Slave Lake, Alberta.

EVS. 1991. Baseline Environmental Studies of the Lesser Slave River, Volume II: Final Report. Prepared for Slave Lake Pulp Corporation, Slave Lake, Alberta.

EVS. 1992a. 1991 Operational Monitoring of the Lesser Slave River, Volume III: Final Report. Prepared for Slave Lake Pulp Corporation, Slave Lake, Alberta.

EVS. 1992b. 1992 Operational Monitoring of the Lesser Slave River, Volume IV: Final Report. Prepared for Slave Lake Pulp Corporation, Slave Lake, Alberta.

EVS. 1995a. 1993 Operational Monitoring of the Lesser Slave River, Volume V: Final Report. Prepared for Slave Lake Pulp Corporation, Slave Lake, Alberta.

EVS. 1995b. 1994 Operational Monitoring of the Lesser Slave River, Draft Report. Prepared for Slave Lake Pulp Corporation, Slave Lake, Alberta. 
EVS. 1995c. 1995 Operational Winter Water Quality Monitoring on the Lesser Slave River, Draft Report. Prepared for Slave Lake Pulp Corporation, Slave Lake, Alberta.

EVS. 1996a. 1995 Operational Monitoring of the Lesser Slave River, Draft Report. Prepared for Slave Lake Pulp Corporation, Slave Lake, Alberta.

EVS. 1996b. Lesser Slave River Environmental Effects Monitoring First Cycle Interpretive Report, Draft Report. Prepared for Slave Lake Pulp Corporation, Slave Lake, Alberta.

Resh, V.H., and D.M. Rosenberg. 1984. The Ecology of Aquatic Insects. Praeger, NY. 625 pp.

Stantec Consulting Ltd. (Stantec) and Golder Associates Ltd. (Golder). 1999a. Cycle 2 Environmental Effects Monitoring, Athabasca River Basin Pulp Mills. Volume I: Interpretive Report. Prepared for Weldwood of Canada Ltd., Hinton, Alberta; Alberta Newsprint Company, Whitecourt, Alberta; Millar Western Forest Products Ltd., Whitecourt, Alberta; Slave Lake Pulp, Slave Lake, Alberta; Alberta-Pacific Forest Industries Inc., Boyle, Alberta.

Stantec and Golder. 1999b. Cycle 2 Environmental Effects Monitoring, Athabasca River Basin Pulp Mills. Volume II: Appendix. Prepared for Weldwood of Canada Ltd., Hinton, Alberta; Alberta Newsprint Company, Whitecourt, Alberta; Millar Western Forest Products Ltd., Whitecourt, Alberta; Slave Lake Pulp, Slave Lake, Alberta; AlbertaPacific Forest Industries Inc., Boyle, Alberta.

Stantec. 2000. Benthic Invertebrate Monitoring of the Lesser Slave River, January 2000. Prepared for Slave Lake Pulp Corporation, Slave Lake, Alberta.

\section{Information Sources for Section 4.5 - Riparian Ecosystems}

Alberta Environmental Protection (AEP). 1991. Alberta Vegetation Inventory Standards Manual. Version 2.1. Edmonton, AB.

Alberta Natural Heritage Information Centre (ANHIC). 2004. Natural Boreal Forest Subregion Descriptions. http://www.cd.gov.ab.ca/preserving/parks/anhic/borealforest.asp (Accessed February, 2004). 
Allen, L. 2003. Alberta Natural Heritage Information Centre Preliminary Plant Community Tracking List. Alberta Community Development, Edmonton, Alberta.

Church, M. and M. North. 1996. Post-regulation Morphological Change and Development of Riparian Vegetation Along Peace River: Predictions and Initial Observations. In: Walder, G.L. 1996. Northern River Basins Study Project Report No. 66, Proceedings of the Northern River Basins Study Instream Flow Needs Workshop October 14-15, 1993 , and January 6-7, 1994. Northern River Basins Study, Edmonton, Alberta.

Gom, L.A. and J.M. Mahoney. 2002. Poplar rule curves (PRC): Instream flow needs (IFN) for riparian poplars in the South Saskatchewan River Basin. Part II - Verification and revision of the PRC. Prepared for Alberta Environment, Southern Operations, Lethbridge. $86 \mathrm{p}$.

Rood, S. 1996. Instream Flows and Riparian Forests Along Alberta's Southern and Northern Rivers. In: Walder, G.L. 1996. Northern River Basins Study Project Report No. 66, Proceedings of the Northern River Basins Study Instream Flow Needs Workshop October 14-15, 1993, and January 6-7, 1994. Northern River Basins Study, Edmonton, Alberta.

Rood, S.B. and J.M. Mahoney. 1991. The Biology and Management of Southern Alberta's Cottonwoods. Proceedings of the University of Lethbridge Conference, May 4 to 6 , 1990. University of Lethbridge, Lethbridge, Alberta.

Shultz, R., and J. Bentz. 1990. Integrated Resource Inventory of the Lesser Slave Lake Study Area. Geowest Environmental Consultants Ltd.

Strong, W.L. and K.R. Leggat. 1992. Ecoregions of Alberta. Alberta Forestry, Lands and Wildlife, Land Information Services Division. Edmonton, 1992.

Tellman, Barbara; Cortner, Hanna J.; Wallace, Mary G.; BeBano, Leonard F.; Hamre, R.H.; tech. cords. 1993. Riparian management: common threads and shared interests. A western regional conference on river management strategies. 1993 Feb 4-6; Albuquerque, NM. Gen. Tech. Rep. RM-226. Fort Collins, CO: U.S. Department of Agriculture, Forest Service, Rocky Mountain Forest and Range Experiment Station. 


\section{Information Sources for Section 4.6 - Fish and Fish Habitat}

AENV. 2002. Alberta Environment - Lesser Slave River High and Low Level Fly-over of the Lesser Slave River. October 30, 2002.

Brayford, K. 1998. Fisheries Inventory Results from the Lesser Slave River Downstream of the outfall of the Slave Lake Pulp Mill Collection Permit Return FRL 2749. FWMD-Peace River, 98-2749-FR

Brilling, M. 1989. Lesser Slave River Inventory 1989.

Brilling, M. 1998. Catch summary for the Lesser Slave River test netting.

Brilling, M. 2000. Lesser Slave River Fishway Study.

Eco-Logical Consulting. 2000. An evaluation of a Denil II fishway in the Lesser Slave River. Eco-Logical Consulting. Prepared for Alberta Environment, Northern Boreal Region.

EVS Environmental Consulting (EVS). 1990. Final report baseline environmental studies of the Lesser Slave River EVS Project No. 3/405-03 Volume 2. Fisheries Management, Peace River, Alberta.

Fisheries Management Division. 2002. Lesser Slave River Fall 2002 Inventory, FWMD-Peace River, AB.

Ford, B.S., P.S. Higgins, A.F. Lewis, K.L. Cooper, T.A. Watson, C.M. Gee, G.L. Ennis, and R.L. Sweeting. 1995. Literature reviews of the life history, habitat requirements and mitigation/compensation strategies for thirteen sportfish species in the Peace, Liard and Columbia river drainages of British Columbia. Canadian Manuscript Report of Fisheries and Aquatic Sciences No. 2321. 341 pp.

Golder Associates Ltd. (Golder). 1998. Collection Permit 2746 GL Return - Lesser Slave River, September 21 - 29, 1998. FWMD-Peace River 98-2746-FR

Golder. 2001. Fish Return Licence 01-0805.

Golder. 2003. Results of pre-construction fish sampling and sediment monitoring for pile installation. Memo report to West Shore Constructors Ltd., North Vancouver, BC. Project \# 03-1370-014. 
Hagen, H.K. 1970. Age, growth and reproduction of the mountain whitefish in Phelps Lake, Wyoming. In, Biology of Coregonid Fishes. C.C. Lindsey and C.S. Woods, eds. pp. 399-415. 41

Kellerhals, R., Neill, C.R., and Bray, D.I. 1972. Hydraulic and Geomorphic Characteristics of Rivers in Alberta. Research Council of Alberta, River Engineering Report 72-1.

Langhorne, A. Neufeld, M., Hoar, G., Bourhis, V., Fernet, D.A., Minns, C.K. 2001. Life history characteristics of freshwater fishes occurring in Manitoba, Saskatchewan and Alberta, with major emphasis on lake habitat requirements. Can MS Rpt. Fish Aquatic Sci 2579: xii+170p.

Nelson, J.S., and M.J. Paetz. 1992. The Fishes of Alberta, 2nd. Edition. University of Alberta Press.

Northern River Basin Study (NRBS). 1994a. Northern River Basins Study project report 32 - A general fish and riverine habitat inventory, Athabasca River, April to May, 1992. Prepared by R.L.\&L. Environmental Services Ltd., Edmonton, AB.

NRBS. 1994b. Northern River Basins Study project report 40 - A general fish and riverine habitat inventory, Athabasca River, October 1993. Prepared by R.L.\&L. Environmental Services Ltd., Edmonton, AB.

NRBS. 1995. Northern River Basins Study project report 53 - A general fish and riverine habitat inventory, Athabasca River May 1994. Prepared by R.L.\&L. Environmental Services Ltd., Edmonton, AB.

R.L. \& L. Environmental Services Ltd. (R.L.\&L). 1980. Lesser Slave Lake Regulation Study Fisheries Impact Assessment Addendum 1. Fisheries Impact Assessment of a weir and eight cutoffs on the Lesser Slave River. Prepared for Alberta Environment. Edmonton, Alberta.

Schwalme, K., W.C. Mackay, and D. Lidner. 1985. Suitability of Vertical Slot and Denil Fishways for Passing North-temperate, Non-salmonid Fish. Can. J. Fish. Aq. Sci. 42:1815-1822.

Scott, W.B, and E.J. Crossman. 1973. Freshwater fishes of Canada. Fish. Res. Board. Can., Bull. 184. 966 pp. 



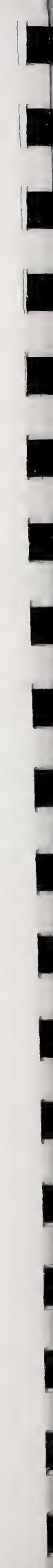




\section{APPENDIX I}

SUPPLEMENTARY HYDROLOGIC AND MORPHOLOGIC DATA 

Figure A-1

Naturalized and Regulated Levels on Lesser Slave Lake (1916-1999)

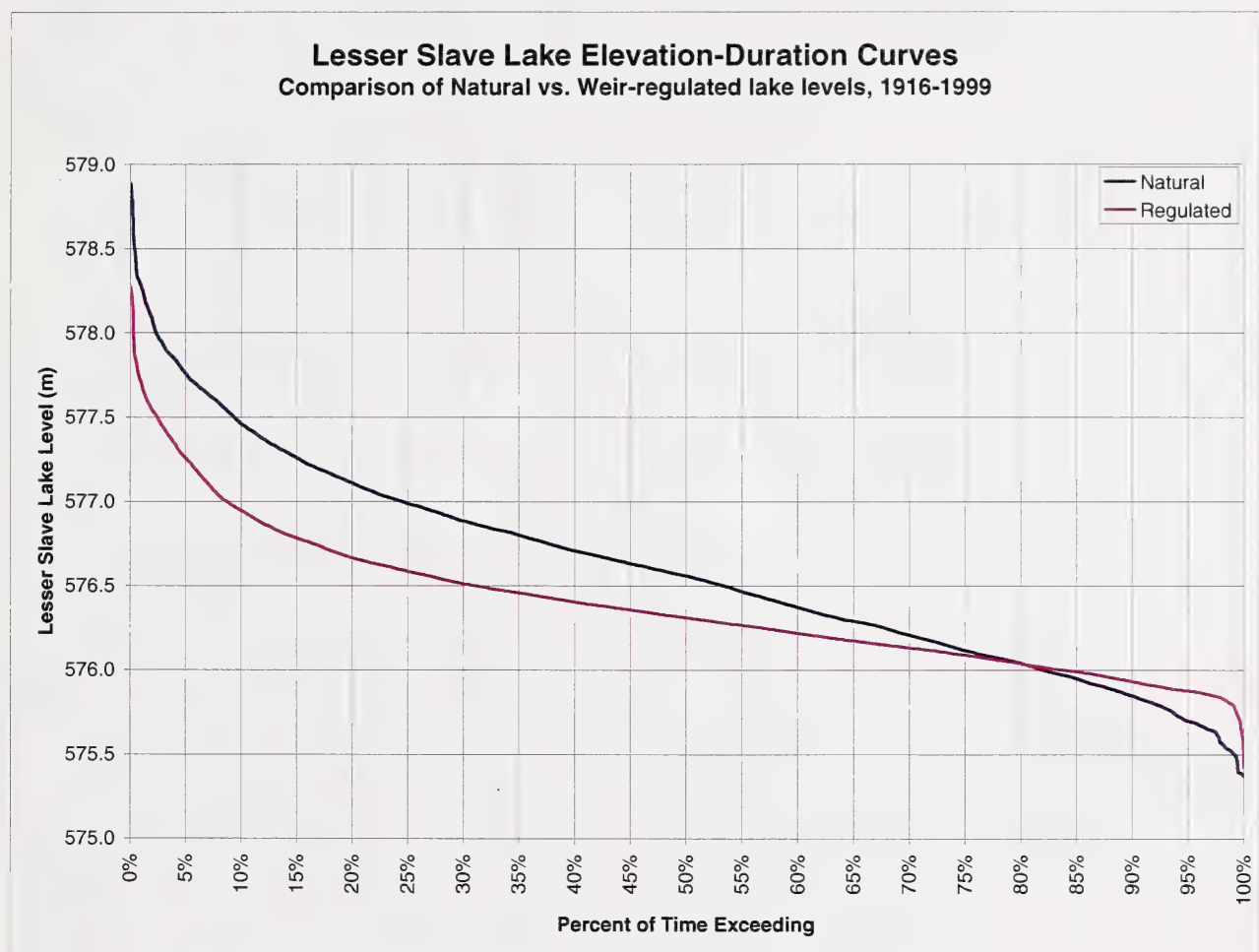



Figure A-2

Comparison of Daily Flow Durations at the Outlet of Lesser Slave Lake Using an Extended (1916-1999) and a Shortened (1970-1999) Time Series

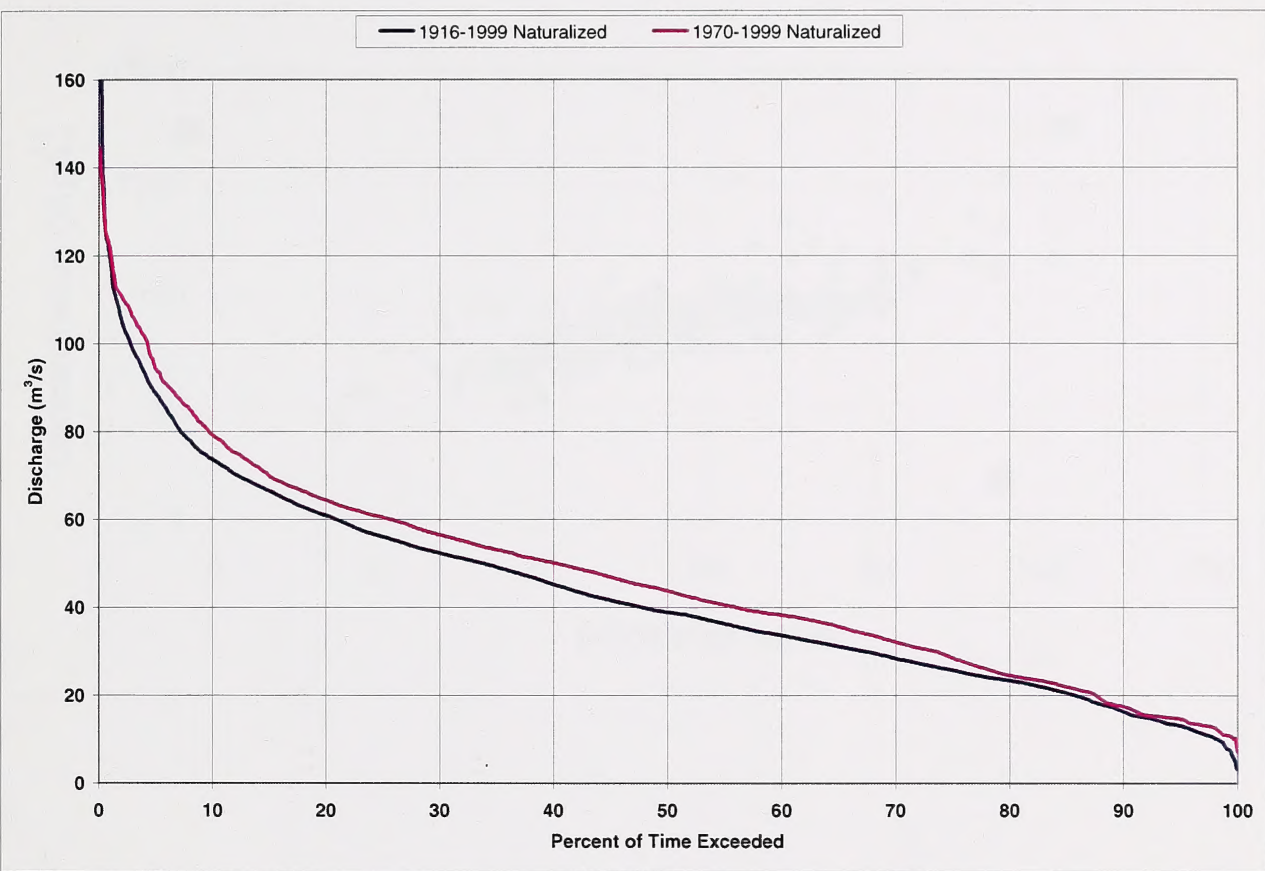


Figure A-3

Scatter Plot of Instantaneous Discharge $\left(\mathrm{m}^{3} / \mathrm{s}\right)$ and Sediment Concentration at Gage 07BK006 near Highway 2A, 1984-1988

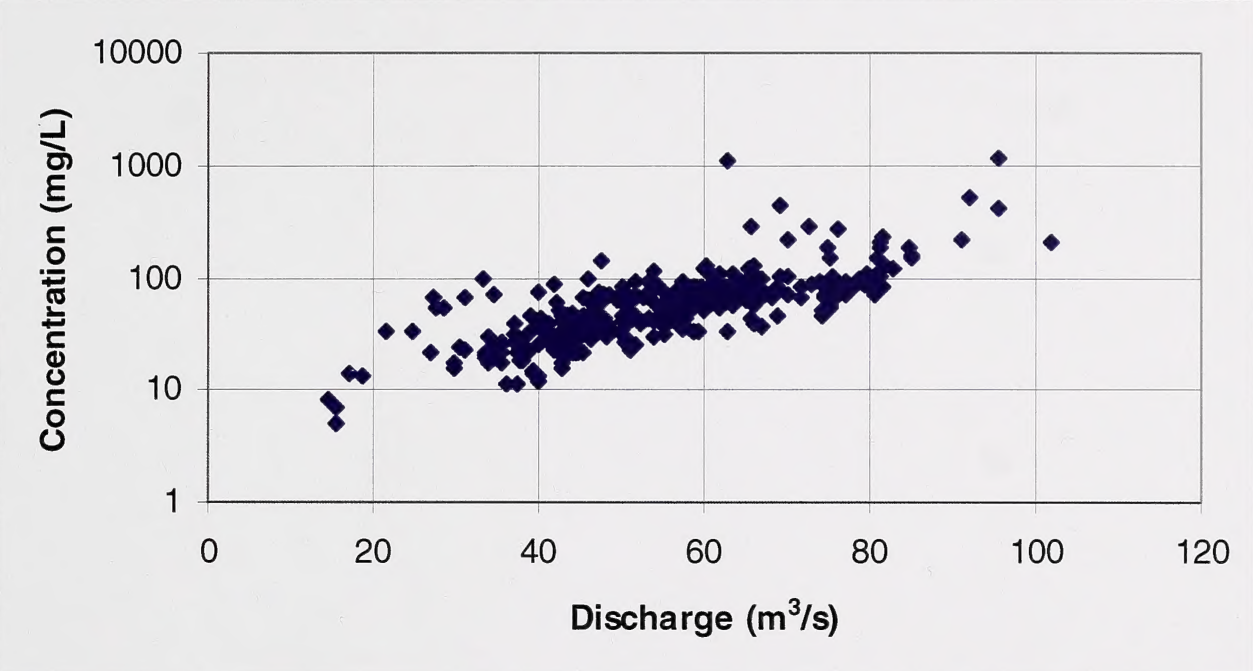


